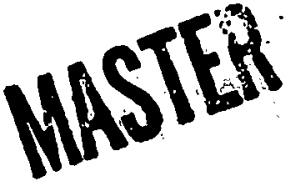

\title{
Irradiation Effects on the \\ Mechanical Properties of \\ Zirconium and Dilute Zirconium Alloys: A Review
}

\author{
P. J. Pankaskie
}

July 15, 1976 


\section{DISCLAIMER}

This report was prepared as an account of work sponsored by an agency of the United States Government. Neither the United States Government nor any agency Thereof, nor any of their employees, makes any warranty, express or implied, or assumes any legal liability or responsibility for the accuracy, completeness, or usefulness of any information, apparatus, product, or process disclosed, or represents that its use would not infringe privately owned rights. Reference herein to any specific commercial product, process, or service by trade name, trademark, manufacturer, or otherwise does not necessarily constitute or imply its endorsement, recommendation, or favoring by the United States Government or any agency thereof. The views and opinions of authors expressed herein do not necessarily state or reflect those of the United States Government or any agency thereof. 


\section{DISCLAIMER}

Portions of this document may be illegible in electronic image products. Images are produced from the best available original document. 


\section{LEGAL NOTICE}

This report was prepared of Butletis is an acceunt of sponsored research artivities. iveither Sponsci nor eatlelle nor ary persun duting in behalf of ather: (a) Makcs uni, warranty or representatior: express ai implied, with: respect to the accuracy, comfletenss, or isdulness of the intcrmation coritaited in this repert, or that the use of any ir:crmation, appdratus, peccess, or compesition disclused in this report may not infinge privately cwned rigints; or (b) Assumes any liabilities with respect to the : :se of, or for damages resulting from the use of, any information, apparatus, process, or comnosition: cisclosed in this eporit.

The iniornation in this repor: has been compled o: publicatiot: by the American joctets

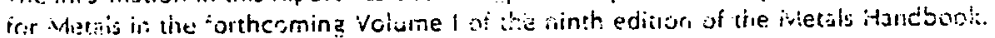


IRRADIATION EFFECTS ON THE MECHANICAL PROPERTIES OF ZIRCONIUM AND DILUTE ZIRCONIUM ALLOYS: A REVIEW

P. J. Pankaskie

July 15, 1976

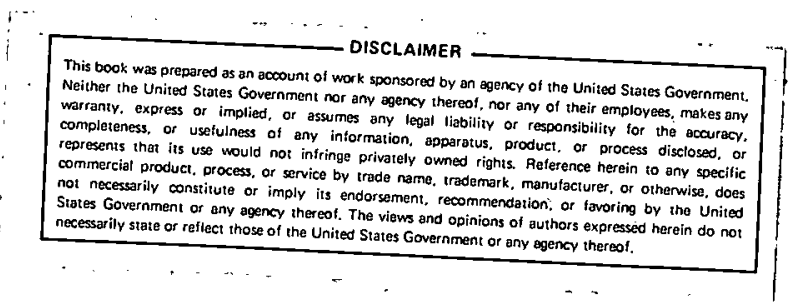

Battelle

Pacific Northwest Laboratories

Richland, Washington 99352 


\section{TABLE OF CONTENTS}

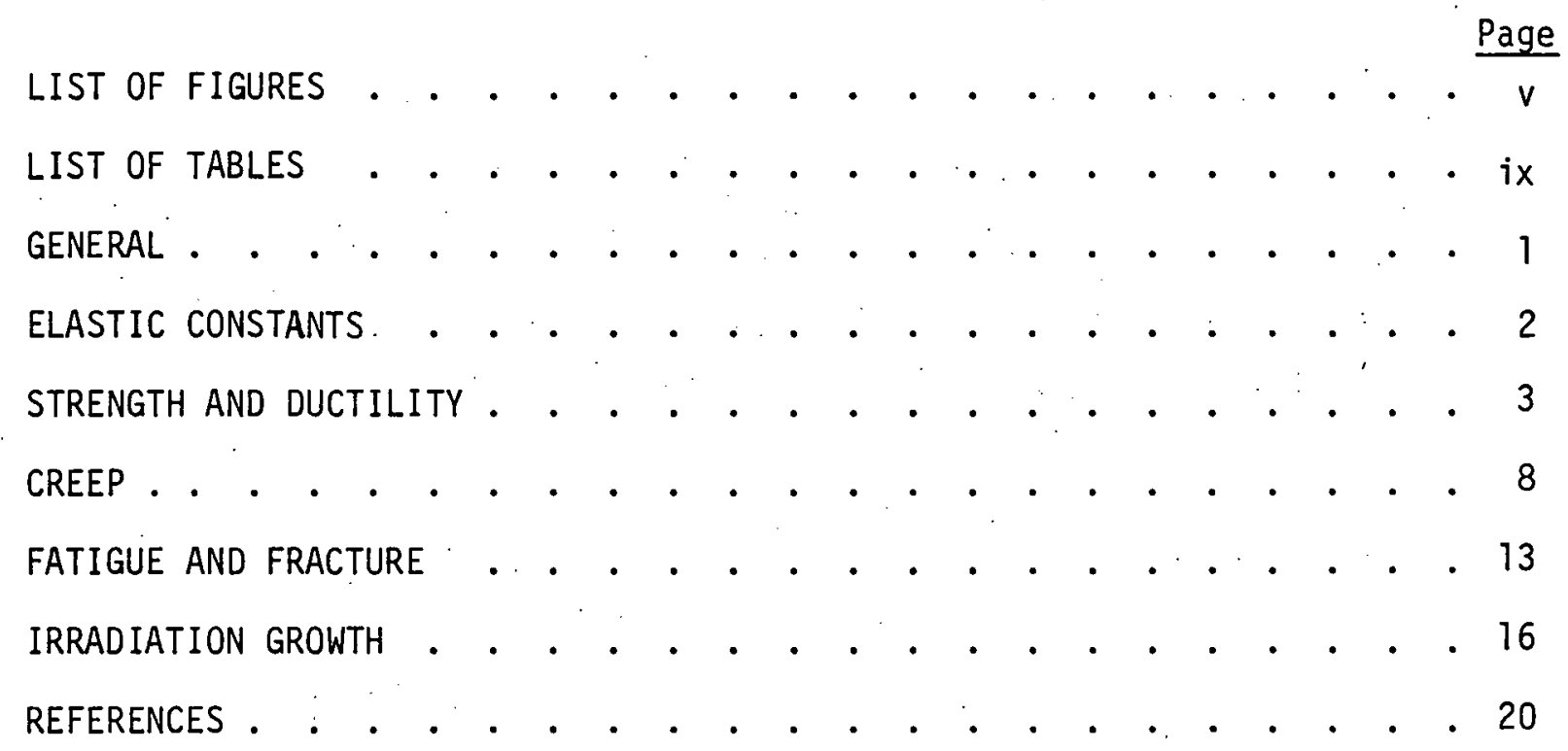




\section{LIST OF FIGURES.}

Page

1a. Strain Aging Versus Temperature for Zircaloy-2 . . . . . . 27

1b. Variation In Creep Rate of Annealed Zircaloy-2 27

1c. Suppression of Strain Aging by Irradiation at a Fluence Greater Than $5 \mathrm{E} 7 \mathrm{~g} \mathrm{n} / \mathrm{cm}^{2}$. . . . . . . . . . . 28

1d. Curve Showing 0.1 Percent Yield Stress of Zircaloy-2

After Post-Irradiation Annealing For One Hour . . . . . . 28

2 Effect of Temperature on the Strength of Irradiated Zircaloy Fuel-Rod Tubing . • . . . . . . . . . . . . 29

3 Effect of Temperature on the Ductility of Irradiated Zircaloy Fuel-Rod Tubing . . . . . . . . . . . . 30

4 Effect of Strain Rate at $370^{\circ} \mathrm{C}$ on the Tensile Properties of Irradiated Zircaloy Fuel-Rod Tubing . . . . . 31

$5 \quad$ Data and Analytical Function for Strain Hardening Coefficient as a Function of Cold Work and Irradiation at Room Temperature . . . . . . . . . . . . . 32

6 Strength Coefficient for Zircaloy-2 as a Function of Cold Work and Fluence . . . . . . . . . . . . . 33

7 Creep Curves for Diametral Creep of Zircaloy-2 Tubes in Thermal Neutron Flux of 1.4 El3 to $1.5 \mathrm{El} 4 \mathrm{n} / \mathrm{cm}^{2}$ $\mathrm{s}$ at $258^{\circ} \mathrm{C}$. . . . . . . . . . . . . . . . 34

8 Creep curves for Diametral Creep of Zircaloy-2 Tubes in a Fast-Flux of $2.56 \mathrm{El} 3 \mathrm{n} / \mathrm{cm}^{2} \mathrm{~s}$ at $258^{\circ} \mathrm{C}$. . . . . 35

9 Curves for Diametral Creep of Quenched, Cold-Drawn and Aged $\mathrm{Zr}-2.5 \% \mathrm{Nb}$, Out-0f-Flux and in a Fast Neutron Flux $\left(2.3 \mathrm{El} 3 \mathrm{n} / \mathrm{cm}^{2} \mathrm{sec}\right) 1 \mathrm{Mev}$ at $295^{\circ} \mathrm{C}$. . . . . . . 36

10 Curves for Diametral Creep of Cold Drawn $\mathrm{Zr}-2.5 \% \mathrm{Nb}$ Out-Of-Flux and in a Fast Neutron Flux $\left(1.9 \mathrm{El} 3 \mathrm{n} / \mathrm{cm}^{2} \mathrm{sec}\right)$

11 Creep Rates of $20 \%$ Cold Drawn Zircaloy-2 Specimens at $263^{\circ} \mathrm{C}$ In- and Out-Of-Neutron Fluxes 
12 Arrhenius Plot of In-Reactor creep Data $\frac{\text { Page }}{39}$

13 In-Reactor Creep of Cold-Worked Zircaloy-2

Showing the Effect of Temperature on Creep Rate . . . . . . 40

14a Unrelaxed Stress Ratio as a Function of Time for Cold-Worked Zircaloy-2 Showing the Behavior of Longitudional and Hoop Specimens In-Reactor at $293^{\circ} \mathrm{C}$ and Comparing the Data for Hoop Specimens

with those from Autoclave-Tests at $-300^{\circ} \mathrm{C}$

14b Unrelaxed Stress Ratio as a Function of Time for Cold-Worked $\mathrm{Zr}-2.5 \mathrm{wt} \% \mathrm{Nb}$ Showing the Behavior of Longitudional and Hoop Specimens In-Reactor at $293^{\circ} \mathrm{C}$ and Comparing the Data for Hoop Specimens with those from Autoclave Tests at $300^{\circ} \mathrm{C}$. . . . . . . . 41

14c Unrelaxed Stress Ratio as a Function of Time for Stress-Relieved Zircaloy-2. Showing the Behavior of Longitudional and Hoop Specimens In-Reactor at $293^{\circ} \mathrm{C}$ and Comparing the Data for Hoop Specimens with those from Autoclave Tests at $300^{\circ} \mathrm{C}$

14d Unrelaxed Stress Ratio as a Function of Time for HeatTreated $\mathrm{Zr}-2.5 \mathrm{wt} \% \mathrm{Nb}$ Showing the Behavior of Longitudional and Hoop Specimens In-Reactor at $293^{\circ} \mathrm{C}$ and Comparing the Data for Hoop Specimens with those from Autoclave Tests at $300^{\circ} \mathrm{C}$

15 Stress Dependence of the In-Flux Creep Rate for Cold-

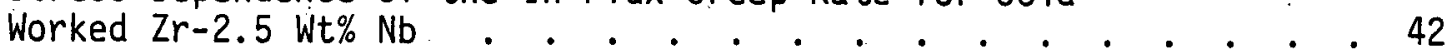

16 Stress Versus Creep Rate Results for $\mathrm{Zr}-2.5$ wt\% Nb From Stress-Relaxation, Uniaxial Creep and Tubes Tests at $284^{\circ} \mathrm{C}$

17 Effect of Alloying on In-Reactor Creep . . . . . . . . . . . . 44

18 Effect of Neutron Flux on Creep Rate of Cold Worked Zircaloy Normalized to an Effective Stress of 20,000 psi and $300^{\circ} \mathrm{C}$. The creep rates plotted represent the total effective creep rate less the effective creep rate measured in tests on unirradiated specimens

19 In-Reactor Creep of Cold Worked Zircaloy-2 Showing Effect of Fast Neutron Flux on Creep Rate . . . . . . . . . . . 46 
20 Calculated Creep Rate as a Function of Irradiation

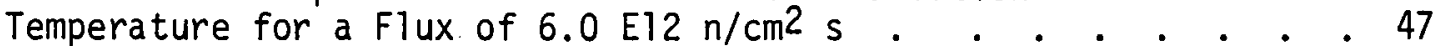

21 Fatigue Data on Unirradiated Zircaloy-2 . . . . . . . . . . . 48

21b Fatigue Data on Irradiated Zircaloy-2

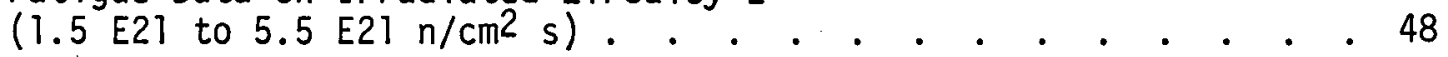

22a Effect of Mean Stress on Fatigue Life . . . . . . . . . . . 49

22b Axial Strain Fatigue Data for Irradiated

Alpha-Annealed Zircaloy-2 at $315^{\circ} \mathrm{C}$. . . . . . . . . . . 49

23 Low Cycle Bending Fatigue Properties of Recrystallized

Zircaloy-2 Before and After Irradiation and at Testing

Temperatures from $20^{\circ} \mathrm{C}$ to $400^{\circ} \mathrm{C}$. . . . . . . . . . . 50

24 Fatigue Crack Growth Rate for Irradiated and

Nonirradiated Zircaloy-4 Rolled Plate . . . . . . . . . 51

25 Effect of Crack Depth and Length on the Fracture

Strength of Hydrided $\mathrm{Zr}-2.5 \mathrm{Nb}$ Tubing at $20^{\circ} \mathrm{C}$ and

Stressed by Internal Pressurization

26 Failure Stress as a Function of the Parameter a/ $\sqrt{\mathrm{RT}}$

for Irradiated and Nonirradiated Zircaloy-2 Tubes

Defected by Machined Slits or Pre-cracked by Fatigue . . . . . 53

27 Room Temperature Fracture Toughness $\left(K_{c r}\right)$ as a Function

of Integrated Fast Flux

28 Differential Growth Strain as a Function of Dose at

Four Different Irradiation Temperatures. The $280^{\circ} \mathrm{C}$

data are derived from instantaneous growth rate

measurements obtained by a transducer technique . . . . . . 55

29 The Fluence Dependence of Irradiation Growth of

Zircaloy-2 and Zircaloy-4 at About $300^{\circ} \mathrm{C}$, Except for

Harbottle's Results, Which were Obtained at $80^{\circ} \mathrm{C}$. . . . . . 56

30 Elongation of Zircaloy-4 Fuel Clad Tubing . . . . . . . . . 57

31 Dependence of Irradiation Growth of $40 \%$ Cold-Worked

Longitudional Slab Specimens of $\mathrm{Zr}-2.5 \mathrm{wt} \% \mathrm{Nb}$ on

Duration of Stress-Relieving at $400^{\circ} \mathrm{C}$. Specimens

irradiated at about $320^{\circ} \mathrm{C}$ to a total dose of

$2.3 \mathrm{E} 20 \mathrm{n} / \mathrm{cm}^{2}$ ( $\left.\mathrm{E}>1 \mathrm{Mev}\right)$ 


\section{THIS PAGE \\ WAS INTENTIONALLY \\ LEFT BLANK}


2a Room Temperature Tensile Properties of Unirradiated and Irradiated Annealed Zircaloy-2. . . . . . . . . . . 60

2b Room Temperature Tensile Properties of Unirradiated and Irradiated Cold-Worked Zircaloy-2 . . . . . . . . . . 60

3 Effect of Irradiation on Mechanical Properties of Zircaloy-2

4a Tensile Properties of NPR Zircaloy-2 Tubes . . . . . . . . 62

4b Tensile Properties of NPR Zircaloy-2 Exposed in the Out-of-Reactor Loop . . . . . . . . . . . . 63

4c Tensile Properties of NPR Zircaloy-2 Tubing Irradiated in the G-7 Hot Water Loop, Irradiation Temperature $-282^{\circ} \mathrm{C}$

4d Tensile Properties of NPR Zircaloy-2 Tube Materials Irradiated in the ETR G-6 Core Position, Irradiation Temperature $-282^{\circ} \mathrm{C}$.

5a Batch Identification and Fabrication Details . . . . . . . . 66

5b Fabrication Route and Texture Characteristics of the Tubing Batches

$5 c$ Closed End Burst Test Properties . . . . . . . . . . . 68

5d Closed End Burst Test Properties . . . . . . . . . . . . . 69

5e Axial Tube Tensile Properties . . . . . . . . . . . . 70

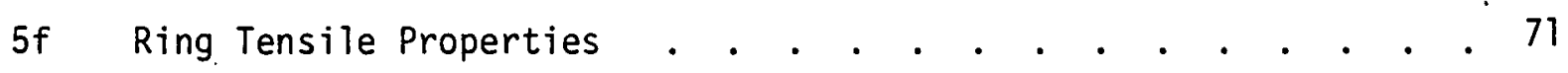

6 Tensile Tests on Longitudional Coupon Cladding

Specimens

7 Tensile Test Data Obtained From Unirradiated and Irradiated Zircaloy-4 (Group A) and Zircaloy-2

(Group B)

8. Tensile Test Data of Irradiated and Unirradiated Zirconium Alloy Specimens Tested at $250^{\circ} \mathrm{C}$ to Determine the Effect of Texture on Strength and Ductility (Strain Rate $0.05 / \mathrm{min}$ ) 
9 Tensile Test Results on Irradiated Saxton Core II

Cladding

10 Post Irradiation Tensile Properties of Zircaloy-2 and -4

11 -In-Flux and Post-Irradiation Data for Zircaloy-4 • • • . • . 77

12 Tensile Test Data of Irradiated and Unirradiated

Zirconium-2.5 wt\% Niobium . . . . . . . . . . . . . . 78

13 Tensile Properties of the $\mathrm{Zr}-2.5 \mathrm{wt} \% \mathrm{Nb}$ Alloy in

Various Metallurgical Conditions . . . . . . . . . . . 79

14a Room Temperature Tensile Data for $\mathrm{Zr}$ Alloys

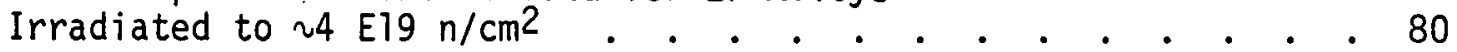

14b $300^{\circ} \mathrm{C}$ Tensile Data for $\mathrm{Zr}$ Alloys Irradiated to

$\sim 4 \mathrm{E} 19 \mathrm{n} / \mathrm{cm}^{2}$. . . . . . . . . . .

15a The Heat Treatment, Hardness and Tensile Properties

of Zirconium Alloys Tested for Creep In-Reactor . . . . . . 82

15b Uniaxial In-Reactor Creep Data at $300^{\circ} \mathrm{C}$. . . . . . . . . 83

15c In-Reactor Creep Tests on Zircaloy-2 . . . . . . . . . . . . . 84

15d In-Reactor Creep of $\mathrm{Zr}-2.5$ wt\% Nb Alloys . . . . . . . . . . 85

16 In-Reactor Creep Tests of Annealed Zirconium . . . . . . . 86

17a. Fatigue Crack Propagation Data for Irradiated and Unirradiated

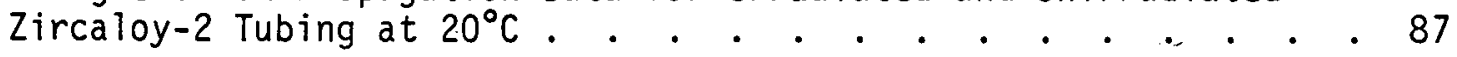

17b Effect of Irradiation on the Fracture Toughness

of Irradiated Zircaloy-4 . . . . . . . . . . . . . . 88

18 Milled Slot Fracture Data for Irradiated and Unirradiated $17 \%$ - 23\% Cold Worked Zircaloy-2 Tubing . . . . . . . . . 89

19 Milled Slot Fracture Data for Irradiated and Unirradiated $30 \%$ Cold Worked Zircaloy-2 Tubing . . . . . . . . . . . . . . 90

20 Effect of Irradiation on the Fatigue Crack Propagation Rate of Zircaloy-4. . . . . . . . . . . . . . . . .

21 Fatigue Crack Growth and Propagation Data for Unirradiated $\mathrm{Zr}-2.5 \mathrm{Wt} \% \mathrm{Nb}$ Alloy Tubing at $20^{\circ} \mathrm{C}$ 
22. Milled Slot Fracture Data for Irradiated and Unirradiated $\mathrm{Zr}-\mathrm{Nb}$ Pressure Tubes . . . . . . . . . . . 93

23. Postirradiation Burst Tests of Zircaloy-2 PRTR Pressure. Tubes

94

24 Irradiation Growth Measurements on Zircaloy-2 . . . . . . . 95 


\section{IRRADIATION EFFECTS ON MECHANICAL PROPERTIES}

\section{GENERAL}

Of the radiation environments, wherein zirconium and dilute zirconium alloys may be used, only "fast" ( $0.1<E<\sim 15 \mathrm{Mev}$ ) neutrons possess energies sufficient to significantly affect the microstructure and those mechanical properties which are structure sensitive. Other radiation sources such as gamma rays, ion bombardment, etc., are capable of altering the atomic structure (e.g., ionization) and/or microstructure but generally are incapable of any significant penetration of metallic materials and are therefore of little practical importance with regard to altering mechanical behavior. For these reasons, this review is 1 imited to the effects of fast flux ( $E \gtrsim 1$ Mev) neutron irradiation.

It has been "fairly well" established through electron microscopy and thermal activation studies $(1-5)$ that fast flux neutron irradiation "strenghtening", in pure fcc metals, is at least qualitatively attributable to two types of "defect clusters" produced by a momentum exchange between high energy neutrons and the lattice atoms. The two types of "defects" which are believed to be the result of the momentum exchange are:

- large interstitial loops whose density tends to saturate at a low fluence (i.e., fast flux $x$ time).

- small, variably sized "planar" vacancy clusters whose density continues to increase approximately linearly with fiuence.

It is generally supposed (1) that the irradiation "strenghtening" mechanism in bcc and hicp metals is similar to that in fcc metals but with the added complication that diffusion of interstitial impurity atoms to the irradiation "defect clusters" can strengthen and stabilize 
them as obstacles to dislocation motion. The diffusion of interstitial impurity atoms can occur either during irradiation and/or after irradiation depending upon temperatures. This phenomenon has been observed in post-irradiation-evaluation. (PIE) annealing studies on niobium. (1.)

The mechanical behavior of $h c p \mathrm{Zr}$ and dilute $\mathrm{Zr}$ alloys is complex due to inherent crystallographic anisotropy and dynamic strain aging characteristics. $(6,7)$ Veevers et al ${ }^{(7)}$ have shown that, for $\mathrm{Zr}-2$, strain aging occurs at temperatures ranging from about $200^{\circ} \mathrm{C}$ through about $450^{\circ} \mathrm{C}$ (see Figure $1 \mathrm{a}$ ). The $300^{\circ} \mathrm{C}$ strain aging peak has been attributed to interstitital oxygen $(7)$ and has a significant effect on creep strength (see Figure 1b). Within the strain aging temperature range, the mechanical behavior tends to be athermal and somewhat unpredictable: ${ }^{(6)}$ After irradiation to a fluence of about $5 E 19 \mathrm{nvt}$ or greater, the oxygen strain aging appears to be effectively suppressed (see Figure 1c) presumably because the oxygen is trapped at irradiation "defect clusters." (7) In PIE annealing tests, an increase in yield strength is observed when annealed at temperatures above the irradiation temperatures (see Figure 1d). Although this phenomenon has not been investigated systematically, these data appear to provide some basis to question whether or not PIE mechanical behavior is fully characteristic of the in-flux mechanical behavior of $\mathrm{Zr}$ and those dilute $\mathrm{Zr}$ alloys susceptible to oxygen strain aging.

\section{ELASTIC CONSTANTS}

For unirradiated $\mathrm{Zr}$ and dilute $\mathrm{Zr}$ alloys, the elastic and shear modulii have been obtained from tests employing both the static stressstra in and dynamic resonant frequency methods $(6,8)$ (see Table 1). There have been no specific in-flux or PIE tests undertaken on the elastic and shear modulii. Based on PIE tensile data, irradiation appears to have no significant effect on the elastic constants. There are only a few instances ${ }^{(8-12)}$ where in contractile/extension strain (Poisson's Ratio) measurements were obtained on either irradiated or unirradiated $\mathrm{Zr}$ and/or dilute $\mathrm{Zr}$ alloys. In those few instances the 
test material from one data set to the next differed significantly (anisotropy in particular). For this reason pre-postirradiation. comparisons cannot be made.

\section{STRENGTH AND DUCTILITY}

The effects of fast flux neutron irradiation on the yield and ultimate strength and ductility of $\mathrm{Zr}$ and the dilute $\mathrm{Zr}$ alloys have, with one notable exception, ${ }^{(13)}$ been determined from PIE tests. Data are available from PIE uniaxial tensile tests on coupon bars and tubing and from biaxial tensile tests on tubing stressed by internal pressurization (see Tables 2 through 1.4). There are no data from PIE tests employing compressive stress states. The data listed in Tables 2 through 14 include the effects of cold work, $(14-20,26)$ heat treatment $(14,15,17,19,20,23,26,27)$ and PIE test temperature. $(11,16,19,20,24)$ Data for evaluating the effect of the irradiation temperature $(2,4,14,18,27)$ and strain rate $(12,13,28)$ are 1 imited. Data relating to in-flux tensile behavior ${ }^{(13)}$ are very 1 imited.

Based on PIE data, the general effects of fast flux ( $E \gtrsim 1 \mathrm{Mev}$ ) neutron irradiation on the tensile properties of $\mathrm{Zr}$ and dilute $\mathrm{Zr}$ alloys are:

- a very substantial increase in yield strength and which tends to approach a saturation value

- a smaller but significant increase in ultimate strenth

- a drastic reduction in uniform (pre-maximum load elongations) strain

- the yield strength tends to approach the ultimate strength. The small difference in yield and ultimate strength and the reduction in uniform strain signal a substantial reduction in strain hardenability.

- the reduction in area, accompanying a tensile failure is essentially unchanged. The reduction in the total tensile elongation essentially reflects only the reduction in uniform strain. 
The increase in yield and ultimate strength, as determined from PIE tests, is dependent upon the prior metallurgical condition. $\mathrm{Zr}$ and dilute $\mathrm{Zr}$ alloys, which have been recrystallization annealed prior to irradiation tend to sustain significantly greater increases in strength than the same alloy(3) which had been cold worked prior to irradiation at the same temperature and fluence. In general, the PIE yield and ultimate strength tend to approach a pseudo-saturation strength at relatively high fluences ( $\phi t \geq 1 E 21 \mathrm{n} / \mathrm{cm}^{2}$ ) and which is essentially independent of the prior metallurgical condition. Although the effects of irradiation temperature have not been systematically studied, there is experimental evidence $(2,4,14,17,27)$ (see also Tables 2, 12 and 14) that the pseudo-saturation strength diminishes with increasing irradiation temperature. PIE annealing experiments (14) tend to show that the irradiation strengthening, sustained from irradiation temperatures below about $280^{\circ} \mathrm{C}$, is removed by annealing at temperatures ranging from about $250^{\circ} \mathrm{C}$ to $400^{\circ} \mathrm{C}$. Irradiation of cold-worked $\mathrm{Zr}-2$ showed ${ }^{(14)}$ the extent of thermally activated recovery, during a $380^{\circ} \mathrm{C}$ irradiation, to be essentially identical to the extent of recovery occurring during an out-of-flux heat treatment for the same time at $380^{\circ} \mathrm{C}$. Considering these data (see also Figures 2 and 3 ), it is expected that, in the temperature range of $\sim 375^{\circ} \mathrm{C}<T \lesssim 475^{\circ} \mathrm{C}$, thermally activated recovery mechanisms will effectively remove irradiation produced "defect clusters" and interstitital loops at about the rate they form or alternatively render them ineffective as obstacles to dislocation motion.

Al though the effect of PIE test temperature has not been systematically studied, some data has been obtained. $(11,16,18,19,23,24,25,27,28)$ As suggested by Makin, (1) interstitital impurity atoms may diffuse to irradiation produced "defect clusters" and strengthen and stabilize them as obstacles to dislocation motion either during and/or after irradiation. As shown in Figure $1 d$, the increase in yield strength suggests that there may have been some further interstitial impurity atom diffusion (i.e., thermal and/or strain aging) when annealed at temperatures above the irradiation temperature. Some of the PIE tensile data (see Tables 5-7, 10-14) show, for some tests, significant differences in the 
normalization factor - $f(Y S) / f(\phi t)^{\star}$ - with testing temperature. These differences in the normalization factor also suggest that some thermal/ strain aging may have occurred in these PIE tests. In some instances, prior metallurgical condition (e.g., alloying, texture, etc.) may have also been a factor in the relatively greater increase in the yield and ultimate strengths.

Only one set of in-flux tensile data was obtained (see Table 11). These data were obtained from uniaxial tests on rolled $2 r-4$ plate. A11 of the in-flux tests were done at slow strain rates (1.9E-4 to 5. OE-6 per hour)-and which are not generally typical of the strain rates employed in the bulk of the PIE tests. A few PIE uniaxial tensile tests were done on the same material but not at identical strain rates. For this reason, exact comparisons of in-flux with PIE tensile behavior are not possible: Although the in-flux test results are variable, the apparent irradiation strengthening effect tends to be significantly less as compared with results from PIE tests. From these data, it cannot be determined whether the differences in irradiation strenthening may be attributable to fast flux and/or fluence differences or to thermal/strain aging effects during the slow strain rate PIE tests.

The effect of strain rate on the post-irradiation tensile behavior of $\mathrm{Zr}$ and dilute $\mathrm{Zr}$ alloys has not been systematically evaluated over any range of test temperatures. The data available are shown in Figure 4 and which were obtained from $\mathrm{Zr}-4$ irradiated to a fluence estimated to range from 3.8 to 4.4 E21 nvt. (2) Comparisons with strain rate effects on non-irradiated $\mathrm{Zr-2}{ }^{(6)}$ show that the strain rate effect on yield and ultimate strength is comparable. In contrast, however,

\footnotetext{
${ }^{*} f(Y S)=\Delta Y S / Y S$ where $\Delta Y S$ is the difference in the irradiated and nonirradiated yield strength only.

$f(\phi t)=\sqrt[4]{1-\exp (-\beta \phi t)}$ where $\phi t=$ fluence.
} 
the total elongation, as measured in the PIE tests, is a maximum at the minimum of the strain rates employed. The reason for this difference is as yet unknown but is probably due, in part at least, to the drastically reduced strain hardenability and tendency for strain localization* generally. observed in PIE tensile tests. The uniform strain tends to be generally. low over the entire range of strain rate employed.

The effect of irradiation superimposed upon cold work effects on the strain hardenability and strength coefficient for $\mathrm{Zr}-2$, has been rather systematically evaluated at room temperature ${ }^{(3)}$ (see figures 5 and 6) but not at elevated temperatures. There are, however, considerable elevated temperature PIE data which, by the small differences between the yield and ultimate strength, show that irradiation drastically reduces the strain hardenability of the $\mathrm{Zr}$ and dilute $\mathrm{Zr}$ alloys. (As shown in Tables $14 a$ and 15b, large strain hardenability values were reported. (27) When compared to the small differences between the PIE yield and ultimate strength, these reported strain hardenability values appear to be erroneous). As stated previously, irradiation at temperatures above about $375^{\circ} \mathrm{C}$ showed that thermally activated recovery occurred at a rate about equal to the rate of irradiation "strengthening". (14) Based on these observations, the strain hardenability, strain rate sensitivity, strength and ductility should approach the values for comparable non-irradiated material.

*The strain localization generally observed in PIE tensile tests have . been referred to by some investigators $(3,12)$ as "dislocation channelling." Transmission electron microscopy studies show the localized slip/shear bands, wherein failure ultimately occurs, to be essentially cleared of dislocations and irradiation produced "defect clusters". 
There have been considerable efforts undertaken to analytically model or empirically account for the inherent anisotropy in the out-of-flux elastic and inelastic mechanical behavior observed. in $\mathrm{Zr}$ and the dilute $\mathrm{Zr}$ alloys. $(6,12,16)$ There have, however, been no specific and systematic efforts to determine whether or not there is anisotropy in the formation of irradiation produced "planar" vacancy clusters and interstitial loops or any accentuation of the anisotropy in the mechanical properties arising from the irradiation produced strengthening effect. Considering Makins'( 1 ) hypothesis for irradiation "strengthening", it may be expected that there can also be some anisotrophy in irradiation effects inasmuch as the irradiation produced "interstitial loops" and "planar vacancy clusters" may form preferentially on favored crystallographic planes. Reiger and Lee ${ }^{(12)}$ undertook a very 1 imited effort to evaluate the effect of texture on the strength and ductility of irradiated and unirradiated $\mathrm{Zr}-2$. From these 1 imited data (see Table 8), it was concluded that the anisotropy in mechanical properties was not significantly altered by irradiation. It is doubtful whether the 1 imited data, shown in Table 8, are adequate to make any generalized conclusion as to anisotropy in irradiation effects.

In summary, the effect of fast flux neutron irradiation on the PIE tensile behavior of $\mathrm{Zr}$ and dilute $\mathrm{Zr}$ alloys appears to be generally characterized by the following:

- At irradiation temperatures above about $375^{\circ} \mathrm{C}$, thermally activated recovery mechanisms tend to operate at rates sufficient to effectively offset the strengthening effect of the irradiation produced "planar" vacancy clusters and interstitial loops.

- At irradiation temperatures below about $375^{\circ} \mathrm{C}$ :

- There is a substantial increase in the yield and a small but still significant increase in the ultimate strength. Both the yield and ultimate strength tend to approach saturation values at fluences estimated to be in the range of E21 to E22 $\mathrm{n} / \mathrm{cm}^{2}$ or perhaps even greater. 
- There is a drastic reduction in uniform strain and the yield tends to approach the ultimate strength. These changes signal a very substantial reduction in strain hardenability。

- There is little or no decrease in the reduction in area and the decrease in tensile elongation essentially reflects the decrease in uniform strain.

- It as as yet unknown whether or not the inherent anisotropy in the hcp. $\mathrm{Zr}$ and dilute $\mathrm{Zr}$ alloys results in anisotropy accentuation in either the formation of or strengthening effects from irradiation produced "planar" vanancy. clusters and/or interstitial loops.

- Data from slow-strain rate in-flux tensile tests and PIE tensile tests at temperatures above the irradiation temperature provide some basis to question whether the tensile behavior observed in PIE tests are always and fully indicative of in-flux tensile behavior.

\section{CREEP}

The effect of fast flux ( $E \gtrsim 1 \mathrm{Mev}$ ) neutron irradiation on the creep behavior of $\mathrm{Zr}$ and dilute $\mathrm{Zr}$ alloys, has, in contrast with PIE tensile data, been determined, in all cases, from in-flux tensile creep tests. Data are available from in-flux uniaxial and biaxial tensile tests on coupon bars and tubing $(29-37,43)$ and biaxial tensile tests on full component sized pressure tubes $^{(42,45)}$ (See Tables 15 and 16 and Figures $7-13,17$ and 18). Significant amounts of data have also been obtained from in-flux tensile stress-relaxation tests. (38-40,49-51) There are few data for evaluating the effect of preirradiation on the in-flux creep behavior and no reported PIE creep data. There are no reported data relating to the in-flux creep behavior for compressive stress states. There are limited amounts of PIE fuel rod profilommetry measurements which may be used in a limited way to evaluate the effect of compressive stress states.

The effect of temperature on the in-flux creep behavior has not been systematically investigated. Nearly all in-flux creep and stress-relaxation data for $\mathrm{Zr}$ and the dilute $\mathrm{Zr}$ alloys were obtained at temperatures ranging 
from about $250^{\circ} \mathrm{C}$ to $500^{\circ} \mathrm{C} .(29-51)$ Most of these data, however, were obtained at temperatures ranging from about $250^{\circ} \mathrm{C}$ to about $325^{\circ} \mathrm{C}$ which corresponds to the temperature range for pressure tube and fuel clad tubing service in water cooled nuclear power reactors. At temperatures below about $350^{\circ} \mathrm{C}$, the creep behavior tends to be athermal for both irradiation and non-irradiation environments. In a non-irradiation environment and in about the $250^{\circ} \mathrm{C}$ to $325^{\circ} \mathrm{C}$ temperature range the creep rates may diminish markedly due to strain aging effects $(30,32)$ (see also. Figure 1b). In contrast, the in-f1ux creep rates always increase with increasing temperatures. (30) As temperatures increase, the effect of irradiation tends to diminish. At temperatures above about $325^{\circ} \mathrm{C}$ to $350^{\circ} \mathrm{C}$, creep tends to be essentially thermally activated with little or no further activation by irradiation. The thermally activated, high temperature creep can be readily modelled by the Arrhenius type function - $\dot{\varepsilon} \propto \exp (-Q / R T)$ - where $Q$ is approximately the activation energy for self diffusion. At temperatures below about $325^{\circ} \mathrm{C}-350^{\circ} \mathrm{C}$, the in-flux creep rates tend to be increasingly activated by fast flux ( $\mathrm{z} 1 \mathrm{Mev}$ ). irradiation with decreasing temperature. In effect, fast neutron irradiation appears to supplant the thermal activation of creep deformation mechanisms. The approach, generally used to date, to analytically model the "low" temperature, irradiation enhanced creep is to use the Arrhenius function - $\exp \left(-Q^{\prime} / R^{\prime}\right)$ with a low valued apparent thermal activation energy and a power function - $\beta \phi^{n}$ - to account for the fast neutron flux activation of creep mechanisms. This approach has been used with reasonable success in modeling the creep behavior of $\mathrm{Zr}-2$ and $\mathrm{Zr}-4^{(41)}$ (see Figure 20). The constitutive equations employed to model the thermally high temperature activated and the low temperature fast flux activated creep are:

- High temperature creep:

$$
\dot{\varepsilon}_{T}=\beta_{T}[1+\alpha k \exp (-k t)] \exp \left(-Q_{T} / R T\right) \cdot \sinh \left(S_{T^{\sigma}}\right)
$$

- Low temperature, irradiation activated creep:

$$
\dot{\varepsilon}_{I}=\beta_{I}[1+\alpha k \exp (-k t)] \phi^{0.85} \cdot \exp \left(-Q_{I} / R T\right) \cdot \sinh \left(S_{I} \sigma\right)
$$


where:

$$
\begin{aligned}
B_{T} & =5.96 \mathrm{El4} \\
B_{I} & =1.62 \mathrm{E}-14 \\
\alpha & =3300 \\
\mathrm{~K} & =4.4 \mathrm{E}-3 \\
Q_{T} & =63600 \mathrm{cal} / \mathrm{mole}{ }^{\circ} \mathrm{K} \\
Q_{I} & =(9500-0.038 \sigma) \mathrm{cal} / \mathrm{mole}^{\circ} \mathrm{K} \\
S_{T} & =6.25 \mathrm{E}-4 \\
S_{I} & =1.0 \mathrm{E}-5-\mathrm{psi}-1 \\
\phi & =\text { fast flux }-\mathrm{nvt}(\mathrm{E} \sim 1 \mathrm{Mev}) \\
\sigma & =\text { applied stress }-\mathrm{psi}
\end{aligned}
$$

The effect of stress on the in-flux creep and stress-relaxation behavior of $\mathrm{Zr}$ and the dilute $\mathrm{Zr}$ alloys has been systematically evaluated over relatively small ranges of temperature and fast neutron flux $(29-39,42-46,49-51)$ (see also Figure 11). As shown in Figure 11, the out-of-flux and thermal flux ( $E \stackrel{\ll}{\varkappa}$ Mev) creep rate-stress dependency tends to be roughly linear. At low stresses, the in-flux creep rates tend to be significantly greater than for out-of-flux creep at otherwise comparable test conditions. With increasingly larger stress, the creep rate enhancement tends to diminish. At temperatures above about $350^{\circ} \mathrm{C}$, any effect of irradiation on the creep rate-stress dependency may be expected to essentially disappear. In analytically modelling the effect of stress on the in-flux creep rate, power functions $-\sigma^{n}$ - and a hyperbolic sine - $\sinh (k \sigma)$ - function have generally been used. The hyperbolic sine function, in effect, models a power function with a continuously changing exponent and therefore appears to provide a slightly better overall representation of the in-flux creep rate-stress dependency.

The effect of the intensity of the fast flux neutron irradiation on the creep behavior of $\mathrm{Zr}$ and the dilute $\mathrm{Zr}$ alloys has not been systematically investigated because the attainable range of fast flux, in any single irradiation facility, is not large. In all analytical modelling efforts, a power function $-\beta \phi^{n}$ - has generally been employed. In these modelling efforts, 
the fast flux exponent ranged from $1.0^{(30-35,38-40,42)}$ to as low as $0.5^{(29)}$ when the effective creep rate was corrected for thermaliy activated creep as determined from out-of-flux creep tests. Considering the uncertainties in reported fast flux intensity and the variation in fast flux intensity over the period of creep observations, it appears that the fast flux exponent is probably greater than 0.5 and less than 1.0 . Several correlation efforts suggest fast flux exponent values at about $0.6^{(30)}$ to $0.85 .^{(41,45)}$ In general, Fidleris ${ }^{(30)}$ reports that:

- in annealed $Z r$ and dilute $Z r$ alloys, the primary creep strains tend to decrease with increasing fast flux intensity whereas in cold worked materials, the fast flux intensity has little or no effect.

- creep rates tend to become constant after fluences ranging from about 1.0 to $5.0 \mathrm{E} 20 \mathrm{n} / \mathrm{cm}^{2}$.

Ibrahim, $(30)$ however, reports that the secondary creep rates continue to diminish with time but at a much slower rate as compared with creep rates for otherwise comparable out-of-flux conditions.

There are only a few in-flux creep tests which were done to evaluate the effect of pre-irradiation. $(30,31)$ In general, pre-irradiation appeared to have little or no effect on material in the cold-worked condition while for material in the annealed condition, pre-irradiation, to fluences of about $1.0 \mathrm{E} 19 \mathrm{n} / \mathrm{cm}^{2}$ or greater, tended to diminish the primary creep strains. At greater fluences (e.g. $\sim 3 E 20 \mathrm{n} / \mathrm{cm}^{2}$ ) pre-irradiation tended to also diminish the primary strains for material in the cold-worked condition. When irradiated in a very high intensity fast neutron flux environment ( $\phi \gtrsim E 14 \mathrm{nv}$ ) the subsequent in-flux (E12 $\delta \lesssim[14 \mathrm{nv}$ ) creep strains and rates were greater than for the in-flux creep strains and rates of comparable material which had not been pre-irradiated.

There have been considerable efforts undertaken to analytically model or empirically account for the inherent anisotropy in the in-flux creep behavior of $\mathrm{Zr}$ and the dilute $\mathrm{Zr}$ alloys. $(6,30,32,33,35,40,47,48)$ There have, however, been no specific and systematic effort to determine whether 
or not there is anisotropy in the formation of irradiation produced "planar" vacancy clusters and interstitial loops or any accentuation of the anisotropy in creep properties arising from irradiation activation and/or enhancement of creep mechanisms. Any effects, if such exist, are inseparably included in all of the reported creep data.

In summary, the effect of fast flux neutron irradiation on the in-flux tensile creep behavior of $\mathrm{Zr}$ and dilute $\mathrm{Zr}$ alloys appears to be generally characterized by the following:

- At irradiation temperatures above about $350^{\circ} \mathrm{C}$, creep tends to be essentially controlled 'only by thermally activated mechanisms.

- At irradiation temperatures below about $350^{\circ} \mathrm{C}$ :

- Creep tends to be irradiation activated and enhanced over and above that for thermal activation at otherwise comparable conditions.

- The extent of creep activation and enhancement by irradiation tends to be inversely proportional to the irradiation temperature.

- At fluences greater than about 1 to $5 E 20 \mathrm{n} / \mathrm{cm}^{2}$, secondary creep rates tend to become constant or at least diminish at a much slower rate as compared with thermally activated creep at otherwise comparable conditions.

- Pre-irradiation appears to have little, if any, effect on material in a cold-worked condition whereas for annealed material, preirradiation to fluences of about $1 E 19 \mathrm{n} / \mathrm{cm}^{2}$ or greater tends to diminish primary creep strains.

C At creep strain rates, $\mathrm{Zr}-2$ and $\mathrm{Zr}-4$ tend to be somewhat superplastic. $(6,41,47)$

- If there is anisotropy in the activation and/or enhancement of creep deformation mechanisms by irradiation, any such effect is inseparabiy included in all of the reported creep data. 
FATIGUE AND FRACTURE

The effect of fast flux neutron irradiation on the fatigue and fracture behavior of several dilute $\mathrm{Zr}$ alloys has been evaluated only in PIE tests. PIE fatigue data have been reported only for the $\mathrm{Zr}-2$ and $\mathrm{Zr}-4$ alloys. PIE fatigue data at temperatures to $400^{\circ} \mathrm{C}$ have been reported for low cycle fatigue in both the axial and bending mode $(52,53)$ (See Figures 21 through 23) and moderate cycle $(20 \mathrm{cpm})$, low stress loading in a tension mode on compact tension specimens from $\mathrm{Zr}-4$ rolled plate. (54) (See Table 17). PIE fatigue crack growth data has been reported for $\mathrm{Zr}-4$ rolled plate in moderate cycle $(20 \mathrm{cpm})$ fatiguing in a tension-tension mode. (54) (See Figure 2a). As yet, all of the fatigue crack growth data reported for the $\mathrm{Zr}-2$ and $\mathrm{Zr}-2.5 \mathrm{Nb}$ alloys has been obtained from large diameter unirradiated tubing. $(55,56,56)$ PIE fracture data have been reported for $\mathrm{Zr}-4$ rolled plate ${ }^{(54)}$ and $\mathrm{Zr}-2$ and $\mathrm{Zr}-2.5 \mathrm{Nb}$

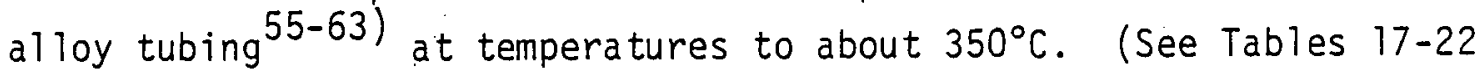
and Figures 25-27).

Data from axial mode, constant strain amplitude fatigue tests on the $\mathrm{Zr}-2$ and $\mathrm{Zr}-4$ alloys in the cold-rolled, recrystallization annealed and the as-welded conditions show no significant effect of either anisotropy or cold-worked substructure. (52) (See Figures 21 and 22). There appears, however, to be some effect of mean stress and strain amplitude (see Figure 22). As to an effect from prior irradiation, it was observed that both the Z-2 and Z-4 alloys, prior to irradiation, tended to strain harden under cyclic loading, whereas after irradiation, they tended to strain soften so that there was no essential difference in the cyclic stressstrain behavior. (53) The only significant effect of irradiation on ductility appears to reduce the allowable stress/strain amplitude. (52) When fatigue tested in the bending mode, the number of cycles to failure appear to be about one-third the number of cycles to failure in axial mode fatigue tests under otherwise comparable test conditions. (53) The bending mode fatigue data show significantly less scatter and appear to fit the Coffin-Manson equation rather we 11:

$$
\Delta \varepsilon_{p} N_{f}^{n}=\text { constant }
$$


where: $\Delta \varepsilon_{p}=$ inelastic strain amplitude

$N_{f}=$ cycles to failure

$n=$ exponent

In the bending mode, irradiation appears to decrease the allowable stress/strain amplitude at $20^{\circ} \mathrm{C}$ but had no significant effect at $300^{\circ} \mathrm{C}$. Heat treatment of identical test material at $300 \mathrm{C}$ for an equivalent test time, or longer, did not significantly alter the tensile yield strength or ductility. Based on these results, it is uncertain as to why there was an effect of irradiation on the bending mode fatigue behavior at $20^{\circ} \mathrm{C}$ but essentially none at $300^{\circ} \mathrm{C}$.

The only reported fatigue crack growth data was obtained from moderate cycle $(20 \mathrm{cpm})$, low stress fatiguing in a tension-tension mode on compact tension specimen from $\mathrm{Zr}-4$ rolled plate. (54) (See Figure 24 ). The compact tension specimens were machined from rolled plate with the following orientations:

$T W '=$ crack plane normal to plate thickness and crack propagation parallel to plate width

$\mathrm{RW}=$ crack plane nomal to rolling direction and crack propagation parallel to plate width

Pre-and-post irradiation fatigue crack growth was determined at $20^{\circ} \mathrm{C}$ for the $\mathrm{Zr}-4$ alloy in both the hydrided and non-hydrided conditions and fluence to about $2.08 \mathrm{E} 21 \mathrm{n} / \mathrm{cm}^{2}$ (see Table $17 \mathrm{a}$ ). As shown in Figure 24, there is appreciable scatter in the PIE fatigue crack growth data. Considering the difficulties in PIE crack growth measurements, it is uncertain as to whether the data scatter is attributable to crack growth measuring difficulties, specimen orientation or both. Considering the rather minimal effect of irradiation observed in the low cycle fatigue behavior $(52,53)$ the effect on fatigue crack growth is also expected to be minimal. Any effect, if it exists, is inseparable from: the scatter in the available data.

The effect of fast flux neutron irradiation on the fracture behavior has been determined for only the $\mathrm{Zr}-2, \mathrm{Zr}-4$ and $\mathrm{Zr}-2.5 \mathrm{Nb}$ al loys at temperatures ranging from about $-70^{\circ} \mathrm{C}$ to $315^{\circ} \mathrm{C}$ in both the hydrided and non-hydrided conditions. $(54,57-63)$ (See Tables $17 \mathrm{~b}-23$ and Figures 24-27). In PIE 
fracture tests, both compact tension specimens and internally pressurized tubular specimens have been used. In fracture tests on tubular specimens, the crack initiating defects employed, were axial slits produced by conventional or electro-discharge machining or pre-cracked by fatigue. In all of the tubular specimen PIE tests, a through-wall defect was employed so as to provide a test specimen analogous to a center-notched sheet fracture specimen. As yet, fracture testing of tubular specimens employing partthrough-wall defects, machined and/or pre-cracked by fatigue, have been done only on the $\mathrm{Zr}-2$ and $\mathrm{Zr}-2.5 \mathrm{Nb}$ alloys in the non-irradiated condition $(55-57)$ (See Figure 25).

In PIE tests employing compact tension specimens from rolled $\mathrm{Zr}-4$ plate, the fracture toughness- $\mathrm{K}_{\mathrm{IC}}$ - for both the hydrided and non-hydrided conditions tended to increase with increasing temperature. ${ }^{(54)}$ (See Table 17b).

The fracture toughness $-K_{C}$-ás determined in PIE fracture tests on through-wall defected $\mathrm{Zr}-2$ and $\mathrm{Zr}-2.5 \mathrm{Nb}$ alloy tubing in the hydrided condition, tends to undergo a transition with increasing temperatures which is analogous to the Charpy impact energy absorption transition. Based largely on data from non-irradiated tubing, the transition temperature ranges from about $100^{\circ} \mathrm{C}$ to about $150^{\circ} \mathrm{C}$ for hydrogen contents ranging from about $100 \mathrm{ppm}$ to $300 \mathrm{ppm}$ respectively. $(55,57,67,63)$ There appears to be 1 ittle or no effect of temperature on the fracture toughness of $\mathrm{Zr}-2$ or $\mathrm{Zr}-2.5 \mathrm{Nb}$ alloy tubing in the non-hydrided condition as determined from PIE fracture tests on through-wall defected tubular specimen. ${ }^{(57-63)}$ (See Tables 20,22, 23 and Figure 26).

There appears to be considerable variance in the observation of the effects of fluence on the fracture toughness of the $\mathrm{Zr}-2, \mathrm{Zr}-4$ and $\mathrm{Zr}-2.5 \mathrm{Nb}$ alloys as determined from compact tension specimens and through-wall defected tubing. As determined in PIE tests with compact tension specimens the fracture toughness tends to increase with increasing fluence even though irradiation, as determined from PIE tensile tests, produces a significant increase in yield strength and a drastic decrease in the strain hardenability. These two material properties are generally considered to be the principle sources of fracture toughness in metals. As determined from PIE fracture 
tests on tubing with machined through-wall defects, there appears to be essentialiy no effect of fast flux neutron irradiation over the entire range of fluence investigated. $(57,60-62)$ (See Figure 26). As determined from PIE fracture tests on tubing, pre-cracked by fatigue, the fracture toughness tends to be generalily less than for tubing with machined throughwall defects and fracture toughness also tends to decrease with increasing fluence. $(57,58)$ (See Figure 27 ).

In summary, the effect of fast flux neutron irradiation on the PIE fatigue crack growth and fracture behavior of several dilute $\mathrm{Zr}$ alloys appears to be generally characterized by the following:

- Data are not available to show whether irradiation has an effect on the fatigue crack growth and fracture behavior that is analogous to that observed for PIE tensile and in-flux creep behavior.

- There are conflicting observations as to the effect of fluence on the PIE fracture toughness. Considering the metallurgical. sources of fracture toughness-modulus, yield strength, strain hardenability and true strain at fracture--it is anticipated that the fracture toughness will diminish with increasing fluence and tend to approach asymptoticaliy a psuedo-saturation fracture toughness analogous to the psuedo-saturation in PIE yield strength.

\section{IRRADIATION GROWTH}

A $11 \mathrm{Zr}$ and dilute $\mathrm{Zr}$ alloys undergo small changes in dimensions during fast ( $E \gtrsim 1 \mathrm{Mev}$ ) neutron irradiations in the absence of any applied stress. These irradiation induced dimensional changes are generally referred to as "irradiation growth" and they tend to occur with essentially no change in density. In general, irradiation growth, in $\mathrm{Zr}$ and the dilute $\mathrm{Zr}$ alloys, is anisotropic and dependent upon both the crystaliographic texture and the deformation substructure. ${ }^{(30)}$ 
The effect of fast neutron flux intensity or flux. spectrum on growth has not been systematically investigated. Based on limited data ${ }^{(30)}$ the irradiation growth rate appears to be directly proportional to the flux intensity in the range of 1 to $20 E 13 \mathrm{n} / \mathrm{cm}^{2} \mathrm{sec} .{ }^{(30)}$ In general irradiation growth is analytically modeled by a power function:

$$
\varepsilon_{\text {growth }}=\text { constant } \times(\phi t)^{n}
$$

where:

$$
\begin{aligned}
& \phi=\text { fast flux }(E \gtrsim 1 \mathrm{Mev}) \mathrm{n} / \mathrm{cm}^{2} \mathrm{sec} \\
& t=\text { time - hours } \\
& n=\text { exponent. }
\end{aligned}
$$

Figures 28 and 29 show the range of exponent determined for the more common $\mathrm{Zr}$ alloy. Figure 30 shows the average for $\mathrm{Zr}-2$ and $\mathrm{Zr}-4$. Inasmuch as the growth rate appears to be directly proportional to the flux intensity, it may be more appropriate to model growth as follows:

$$
\varepsilon_{g}=\text { constant } \times \phi \times t^{n}
$$

Measurements of dimensional changes due to irradiation have been obtained from irradiations at temperatures ranging from about $78^{\circ} \mathrm{K}\left(-195^{\circ} \mathrm{C}\right)(65)$ to as high as about $350^{\circ} \mathrm{C} .(68)$. (See also Figures 28 through 30.$)$ Based on these data, and his own unpublished data, Fidleris ${ }^{(30)}$ suggests a small irradiation growth-temperature dependence which may be represented by the Arrhenius function:

$$
\dot{\varepsilon}_{g} \propto \exp \left(-Q_{g} / R T\right)
$$

The activation energy - $Q_{g}$ - was estimated to be about $4 \mathrm{kcal} / \mathrm{mole} \mathrm{o}^{\circ} \mathrm{K}$ in the temperature range of about $150^{\circ} \mathrm{C}$ to $300^{\circ} \mathrm{C}$. Considering the data shown in Figures 28 through 30 , and the observation that irradiation growth appears to be significantly greater in material in the cold worked condition than in a stress relieved or the recrystallization annealed condition, there appears 
There are anomalies in the observed irradiation growth of annealed zirconium single crystals. ${ }^{(30)}$ In one experiment, expansion occurred along the "a" axis of the hcp $\mathrm{Zr}$, and contracted along the " $c$ " axis with no net volume change. In another experiment, expansion occurred predominantly along the "a" axis and with also a slight expansion along the "c" axis after irradiation to a fluence of about $7 E 20 \mathrm{n} / \mathrm{cm}^{2}$. In still another experiment, Fidleris ${ }^{(30)}$ observed expansion predominantly along the " $c$ " axis. After irradiation to a fluence of about $6 \mathrm{E} 19 \mathrm{n} / \mathrm{cm}^{2}$, contraction along the " $\mathrm{C}$ " axis was observed to begin although there was still a net " $c$ " axis growth after irradiation to a fluence of about $8 \dot{E} 19 \mathrm{n} / \mathrm{cm}^{2}$. Irradiation growth experiments have not been done on plastically deformed single crystals.

Significant amounts of irradiation growth data have been obtained from polycrystalline $\mathrm{Zr}$ and dilute $\mathrm{Zr}$ alloys in both the annealed and cold worked condition. $(30,64-71)$ (See Table 24 and Figures 28 through 30 ). These data show that irradiation growth and growth rates tend to be greater in material in the cold worked condition than in either the stress relieved or the annealed and recrystallized condition. (See Figures 29 through 31). A 11 data show that the direction of irradiation growth tends to coincide with the principal direction of plastic deformation during cold working. Post-irradiation, recrystallization annealing experiments $(30)$ show that irradiation growth strain recovery occurs and that the fractional strain recovery is inversely proportional to the degree of cold work. The maximum strain recovery, however, was insensitive to the degree of cold work. These observations and the anomalies observed in the growth of $\mathrm{Zr}$ single crystals, suggest that irradiation growth is as much or perhaps more dependent upon the cold work substructure as upon the crystallographic texture. In considering the crystallographic textures in cold-worked or cold-worked and recrystallization annealed material, irradiation growth appears to occur by expansion along the "c" axis and contraction along the "a" axis. In most investigations, however, dimensional change measurements were limited to one (i.e., plastic flow direction) or two (i.e., transverse to the direction of plastic flow) directions. For this reason, there is still considerable uncertainty as to the crystallographic directions of growth and whether or not there are net volume changes resulting from irradiation growth. Microscopy studies have not as yet disclosed any void formation associated with the irradiation growth phenomena. 
to be some uncertainty as to any irradiation growth-temperature dependence. Considering that the in-flux creep behavior, and to a lesser extent, the PIE tensile behavior appear to be inversely temperature dependent, an inverse growth-temperature dependence might also be expected.

In summary, the effect. of fast flux irradiation on the unstressed growth behavior of $\mathrm{Zr}$ and dilute $\mathrm{Zr}$ alloys appears to be generally characterized by the following:

- There are no data from irradiations above about $350^{\circ} \mathrm{C}$ to $375^{\circ} \mathrm{C}$ to determine any irradiation-growth effect. Based on observations of the effect of irradiation on the PIE tensile and the in-flux creep behavior, it is anticipated that irradiation growth will be minimal or nonexistent.

- At irradiation temperatures below about $350^{\circ} \mathrm{C}$ to $375^{\circ} \mathrm{C}$ :

- Irradiation tends to produce dimensional changes in the absence of any applied loading.

- The anisotropy in irradiation growth appears to, be dependent upon both the crystallographic texture and the cold worked substructure.

- The rate and magnitude of irradiation growth appear to be significantly greater in material in the cold worked condition than in a stress relief or the recrystallization annealed condition.

- The direction of irradiation growth tends to coincide with the direction of plastic flow during prior cold working.

- Irradiation growth, within at least a limited range of fast flux intensity, appears to be directly proportional to the fast flux intensity.

- Post-irradiation annealing appears to produce some recovery of irradiation produced growth strains. The magnitude of recoverable growth strains appears to be independent of the condition (e.g., degree of cold work, stress relief or recrystallization anneal) of the material.

The available irradiation growth data appear to be inadequate to establish, with reasonable certainty, any irradiation growth-temperature dependence. 


\section{REFERENCES}

1. M. J. Makin, "The Hardening of Metals by Irradiation," Irradiation Embrittlement and Creep in Fuel Cladding and Core Components, Proceeding of the Conference Organized by the British Nuclear Energy Society in London, November 9-10, 1972.

2. H. R. Higgy and F. H. Hammand, "Effect of Neutron Irradiation on the Tensile Properties of Zircaloy-2 and Zircaloy-4," Journal of Nuclear Materials, Vol. 44, pp. 215-227, 1972.

3. A. L. Bement, "Fundamental Materials Probiems in Nuclear Reactors," Second International Conference on the Strength of Metals and Alloys, August 30 - September 9, 1970, Conference Proceedings, Vol. 2, American Society. for Metals.

4. Z. M. Hammad, B. D. Sharma and P. Rodriquez, "Radiation Hardening of Zirconium," B.A.R.C-578, 1971, Bhaba Atomic Research Centre, Bombay, India.

5. D. 0. Northwood and R. W. Gilbert, "Neutron Radiation Damage in Zirconium and It's Alioys," Radiation Effects, Vol. 22, 1974, pp. 139140 .

6. C. L. Mohr, P. J. Pankaskie and F. E. Panisko, "A State-of-the-Art Report on the Anisotropic Deformation and Analys is of Zircaloy," RP-251-1, 1976, (EPRI/MPC Zircaloy-LOCA Program).

7. K. Veevers, W. B. Rotsey, and K. U. Snowden, "The Effect of Neutron Irradiation and Cold Work on the Strain-Aging Behavior of Zircaloy-2." Applications Related Phenomena for Zirconium and It's Alloys, ASTM STP 458, 1969, pp. 194-209.

8. D. 0. Northwood, I. M. London and L. E. Bahen, "Elastic Constants of Zirconium Alloys," Journal Nuclear Materials, Vol. 55, p. 299-310, 1975.

9. P. L. Rittenbouse and M. L. Picklesimer, "Research on the Anisotropy of Zircaloy-2," Electrochemical Technology, Vol. 4, no. 7-8, pp. 322-329, 1966.

10. C. R. Woods, Editor, Properties of Zircaloy-4 Tubing, WAPD-TM-585, 1966.

11. C. D. Williams, R. B. Adams on and K. D. Olshausen, "Effects of Boiling Water Reactor Irradiation on Tensile Properties of Zircaloy, "European Conference on Irradiation Behavior of Fue 1 Cladding and Core Component Materials, Karlsruhe, 3-5. December, 1974, pp. 189-192. 
12. G. F. Reiger and D. Lee, "Strength and Durability of Neutron Irradiated and Textured Zircaloy-2", Zirconium in Nuclear Applications, ASTM STP 551,197, p. 355-369.

13. F. J. Azzarto, E. E. Baldwin, F. W. Wiesinger and D. M. Lewis, "Unirradiated, In-Pile and Post-Irradiation Low-Strain Rate Tensile Properties of Zircaloy-4", Journal of Nuclear Materials, Vol. 30, 1969, pp. 208-218.

14. L. M. Howe and W. R. Thomas, "The Effect of Neutron Irradiation on the Tensile Properties of Zircaloy-2", Journal of Nuclear Materials, Vol. 2, no. $3,1960, \mathrm{pp} .248-260$.

15. L. M. Howe, "The Annealing of Irradiation Damage in Zircaloy-2 and the Effect of High Temperature Irradiation on the Tensile Properties of Zircaloy-2", CR Met-922, April 1960,

16. A. L. Bement Jr., "Effects of Cold Work and Irradiation on the Tensile Properties of Zircaloy-2", HW-74955, April 1963.

17. J. E. Irvin, "Effects of Irradiation and Environment on the Mechanical Properties and Hydrogen Pickup of Zircaloy", Electrochemical Technology, Vol. 4, no. 5-6, May-June, 1966, pp. 240-249.

18. M. Kangiloski, "The Effects of Neutron Radiation on Structural Materials", N68-16876, June 30, 1967, Battelle Memorial Institute, Columbus, Ohio.

19. D. G. Hardy, "The Effects of Neutron Irradiation on the Mechanical Properties of Zirconium Alloy Fuel Cladding in Uniaxial and Biaxial Tests", Irradiation Effects on Structural Alloy for Nuclear Reactor Applications, ASTM, STP484, 1970, pp. 215-258.

20. D. G, Hardy, "Burst Testing of Zircaloy Cladding from Irradiated PickeringType Fuel Bundles", Effects of Radiation on Substructure and Mechanical Properties of Metals and A17oys, ASTM, STP 529, 1973, pp. 415-434.

21. D. L. Hagrman, "Irradiation and Cold Work Effect on Zircaloy Cladding Mechanical Properties", SRD-42-76, January 1976.

22. C. J. Baroch, A. V. Munin, and E. N. Harbinson, "Effects of Irradiation in a Thermal Reactor on the Tensile Properties of Zircaloy-2 and 4 and Borated Stainless Steel", Irradiation Effects on Structural Alloys for Nuclear Reactor Applications, ASTM, STP 484, 1970, pp. 176-193.

23. C. E. Ells and V. Fidleris, "Effect of Neutron Irradiation on Tensile Properties of the Zirconium-2.5 Weight Percent Niobium Alloy". Electrochemical Technology, Vol. 4, no. 5-6, May-June 1966, pp. 268-274. 
24. F. H. Megerth, "Zircaloy Clad-UO 2 Fuel Rod Evaluation Program", GEAP 10070, July 1969.

25. W. R. Smalley, "Saxton Plutonium Program, Semiannual Progress: Report for the Period Ending December 31, 1969, WCAP-3385-22, March. 1970.

26. W. R. Smalley, "Effects of Irradiation on Mechanical Properties of CVTR Pressure Tube Material", CVNA-159, September 1962.

27. B. A. Cheadle, C. E. Ellis, and J. van der Kuur, "Plastic Instability in Irradiated Zircaloy-Sn and Zircaloy-Nb A11.oys", Zirconium in Nuclear. Applications, ASTM, STP 551, 1974, pp. 370-384.

28 A. A. Bauer, et al., Unpublished Data, Battelle Memorial Institute.

29. E. R. Gilbert, "In-Reactor Creep of Reactor Materia1s", Reactor Technology, vol. 14, no. 3, fall 1971, pp. 258-285.

30. V. Fidleris, "Summary of Experimental Results on In-Reactor Creep and Irradiation Growth of Zirconium Alloys", Atomic Energy Review, vol. 13, no. 1,1975 , pp. 51-80.

31. V. Fidleris, "Uniaxial In-Reactor Creep of Zirconium Alloys", Journal of Nuclear Materials, vol. 26, no. 1, 1968, pp. 51-76.

32. V. Fidleris, "The Effect of Texture and Strain Aging on Creep of Zircaloy-2", Application-Related Phenomena for Zirconium and Its Alloys, ASTM, STP 458, 1968, pp. 1-17.

33. E. F. Ibrahim, "In-Reactor Creep of Zirconium-Alloy Tubes and Its Correlation with Uniaxial Data", Applications-Related Phenomena for Zirconium and Its AlToys, ASTM, STP 458, 1968, pp. 18-36.

34. E. F. Ibrahim, "In-Reactor Creep of Zircaloy-2.5\% Nb. Tubes at $570^{\circ} \mathrm{K}$ ", Zirconium in Nuclear Applications, ASTM, STP 551, 1974, pp. 249-261.

35. E. F. Ibrahim, "In-Reactor Tubular Creep of Zircaloy-2 at 260 to $300^{\circ} \mathrm{C}$ ", Journal of Nuclear. Materials, vol. 46, 1973, pp. 169-182.

36. J. J. Holmes, J. A. Williams, D. H. Nyman and J. C. Tobin, "In-Reactor Creep of Cold Worked Zircaloy-2", Flow and Fracture of Metals in Nuclear Environments, ASTM, STP 380, 1964, pp. 385-394.

37. E. R. Gilbert and N. E. Harding, "Comparison on In-Reactor Creep and Postirradiation Creep Tests of Structural Materials for Nuclear Applications", Irradiation Effects in Structural Alloys for Thermal and Fast Reactors, ASTM, STP 457, 1969.

38. D. E. Fraser, P. A. Ross Ross, and A. R. Causey, "The Relation Between Stress-Relaxation and Creep for Some Zirconium A7loys During Neutron Irradiation", Journal of Nuclear Materials, vol. 46, 1973, pp. 381-392. 
39. C. E. Coleman and E. F. Ibrahim, "In-Reactor Creep Ductility of Zirconium Alloys," Unpublished Data transmitted to PNL under AECL/ USNRR information exchange, June 1975.

40. P. A. Ross Ross, V. Fidleris and D.E. Frazer, "Anisotropic Creep Behaviour of Zirconium Alloys in A Fast Neutron Flux, "Canadian Metallurgical Quarterly, Vol. II, No. 1. 1972, pp. 101-1.11 (also AECL-4237)

41. P. J. Pankaskie, "BUCKLE, An Analytical Computer Code for Calculating Creep Buckling of in Initially Oval Tube," BNWL-1784, May 1974.

42. P. A. Ross Ross and C. E. L. Hunt, "The In-Reactor Creep of Cold Worked Zircaloy-2 and Zirconium 2.5 wt \% Niobium Pressure Tubes," Journal of Nuclear. Materials, Vol. 26, no. 1,1968 , pp. 2-17.

43. E. R. Gilbert, "In-Reactor Creep of $\mathrm{Zr}-2.5 \mathrm{wt} \% \mathrm{Nb}$," Journal Nuclear Materials, Vo1. 26, no. 1, 1968, pp. 105-111.

44. P. H. Kreyns and M. W. Burkart, "Radiation Enhanced Relaxation in Zircaloy-4 and in A Zirconium $+2.5 \mathrm{w} / 0$ Niobium $+0.5 \mathrm{w} / 0$ Copper Alloy," Journal of Nuclear Materials, Vol. 26, no. 1, 1968, pp. 87-104.

45. B. Watkins and D. S. Wood, "The Significance of Irradiation Induced Creep on Reactor Performance of A Zircaloy-2 Pressure Tube," ApplicationsRelated Phenomena For Zirconium And Its Alloys, ASTM STP 458, 1969 , pp. 18-36.

46. V. Fidleris, "The Stress Dependence of The In-Reactor Creep Rate of Heat Treated $\mathrm{Zr}-2.5 \mathrm{wt} \% \mathrm{Nb}$ and Cold Worked Zircaloy-2," Journal of Nuclear Materials, צol. 36, 1970, pp. 343-346.

47. D. S. Wood and B. Watkins, "A Creep Limit Approach to the Design of Zircaloy-2 Reactor Pressure Tubes at $275^{\circ} \mathrm{B}, "$ Journal of Nuclear Materials, vo1. 41,1971 , pp. 327-340.

48. P. A. Ross Ross and V. Fidleris, "Design Basis for Creep of Zirconium Alloy Components in a Fast Neutron Flux, "Paper C216/73, International Conference on Creep and Fatigue in Elevated Temperature Application," Instn Mech Engrs. Conference Publication 13, 1973.

49. A. R. Causey, "In-Reactor Stress Relaxation of Zirconium A1 loys," Zirconium in Nuclear Applications ASTM STP 551, 1973, pp. 263-273.

50. C. C. Dollins and R. P. Tucker, "Irradiation-Induced Primary. Creep," Journal of Nuclear Materials, Vol. 52, 1974, pp. 277-288.

51. A. R. Causey, "In-Reactor Creep of Zircaloy-2, Zircaloy-4 and Zr-1.15 wt \% $\mathrm{Cr}-0.1$ wt \% $\mathrm{Fe}$ at 568K Derived from Their Stress-Relaxation Behaviour," Journal of Nuclear Materials, Vol. 54, 1974, pp. 64-72. 
52. W. J. O'Donnell and B. F. Langer, "Fatigue Design Basis for Zircaloy Components," Nuclear. Science and Engineering 20, 1964, pp. 1-12.

53. Kjell Pettersson, "Low Cycle.Fatigue Properties of Zircaloy-2 Cladding," Journal of Nuclear Materials, Vol. 56, 1957, pp. 91-102.

54. T. J. Walker and J. N. Kass, "Variation of Zircaloy Fracture Toughness in Irradiation," Zirconium in Nuclear Applications, ASTM STP 551, 1974, pp. 328-354.

55. S. Kusumoto, A. Nishioba, H. Maki, S. Usami, K. Hayashi, and Y. Ando, "Effects of Hydrogen Content, Temperature, and Crack Configuration on Fatigue Crack Propagation and Unstable. Fracture Behavior of $\mathrm{Zr}-2.5 \mathrm{Nb}$ Pressure Tube," Conf - 7309 A2 - P2.

56. P. J. Pankaskie, "Fatigue-Crack Growth and Propagation in $2.5 \mathrm{Nb}$ Zirconium Alloy Pressure Tubing," Application-Related Phenomena for Zirconium and its Alloys, ASTM, STP 458, 1969, Pp: 129-140.

57. P. J. Pankaskie, Unpubl ished Data.

58. P. A. Carlson, A. Russe11, and J. P. Schmidt, "Zircaloy-2 Pressure Tube Experience at the $N$ Reactor, "Transactions of the American Nuclear Society, Vo1. 16, Annual Meeting, Chicago 10-14 June 1973.

59. L. A. James and T. R. Ostrum, "Fracture Behavior of Flawed Zircaloy-2 Pressure Tubes," Nuclear Engineering and Design, 1970.

60. W. J. Langford and L. E. J. Mooder, "Metallurgical Properties of Irradiated Cold-Worked $\mathrm{Zr}-2.5$ wt \% Nb Pressure Tubes," Journal of Nuclear Materials, Vol. 39, 1971, pp. 292-302.

61. A. Cowan and W. J. Langford, "Effect of Hydrogen and Neutron Irradiation on the Failure of Flawed Zircaloy-2 Pressure Tubes, "Journal of Nuclear Materials, Vol. 30, 1969, pp. 271-281.

62. W. J. Langford, "Metallurgical Properties of Cold-Worked Zircaloy-2 Pressure Tubes Irradiated under CANDU-PHW Power Reactor Conditions," ASTM STP 484, 1970, pp. 259-286.

63. M. C. Frazer, Postirradiation Evaluation of Zircaloy-2 PRTR Pressure Tubes - Part III," BNWL-5, January 1965.

64. R. V. Hesketh, J. E. Harbottle, N. A. Waterman and R. C. Lobb, "Irradiation Growth and Creep in Zircaloy-2," Proceeding of the Symposium on Radiation Damage in Reactor Materials, Vo1. 1, 1969, International Atomic Energy Agency, Vienna. 
65. J. E: Harbottle, "The Temperature and Neutron Dose Dependence of Irradiation Growth in Zircaloy-2," Irradiation Effects on Structura 1 Alloys for Nuclear Reactor Applications, ASTM STP 484, 1970, pp. 287-299.

66. V. Fidleris, "The Effect of Cold-Work and Stress-Relieving on the Irradiation Growth. Behavior of Zirconium Alloys," Journal of Nuclear Materials, Vol. 46, 1973, pp. 356-360.

67.... E. F... Ibrahim and J...E. Winegar, "Dimensional Changes of Unstressed Zircaloy-2 and $\mathrm{Zr}-2.5$ wt \% Nb Specimens in a Fast Flux, "Journal of Nuclear Materials, Vol. 45, 1972/3 pp. 335-338.

68. R. N. Duncan, N. Fuhrman, J. C. LaVake, H. Knaab, and R. Manzel, "Dimensional Stability of Water Reactor Fue?," 75-CNA/ANS-100, Proceedings of the Joint Topical Meeting on Commercial. Nuclear Fuel Technology Today, Apri1 28-30, 1975, Toronto.

69. G. J. C. Carpenter and D. 0. Northwood, "The Contribution of Dislocation Loops to Radiation Growth and Creep of Zircaloy-2," Journal off. Nuclear Materials, Vol. 56, 1975, pp. 260-266.

70. R. V. Hesketh, "Non-Linear Growth in Zircaloy-4," Journal of Nuclear Materials, Vol. 30, 1969, pp. 219-221.

71. S. N. Buckley, "Irradiation Growth and Irradiation Enhanced Creep in F. C. C. and B. C. C. Metals," UKAEA Report AERE-R5944, Vol. I I., pp. 547-565. 


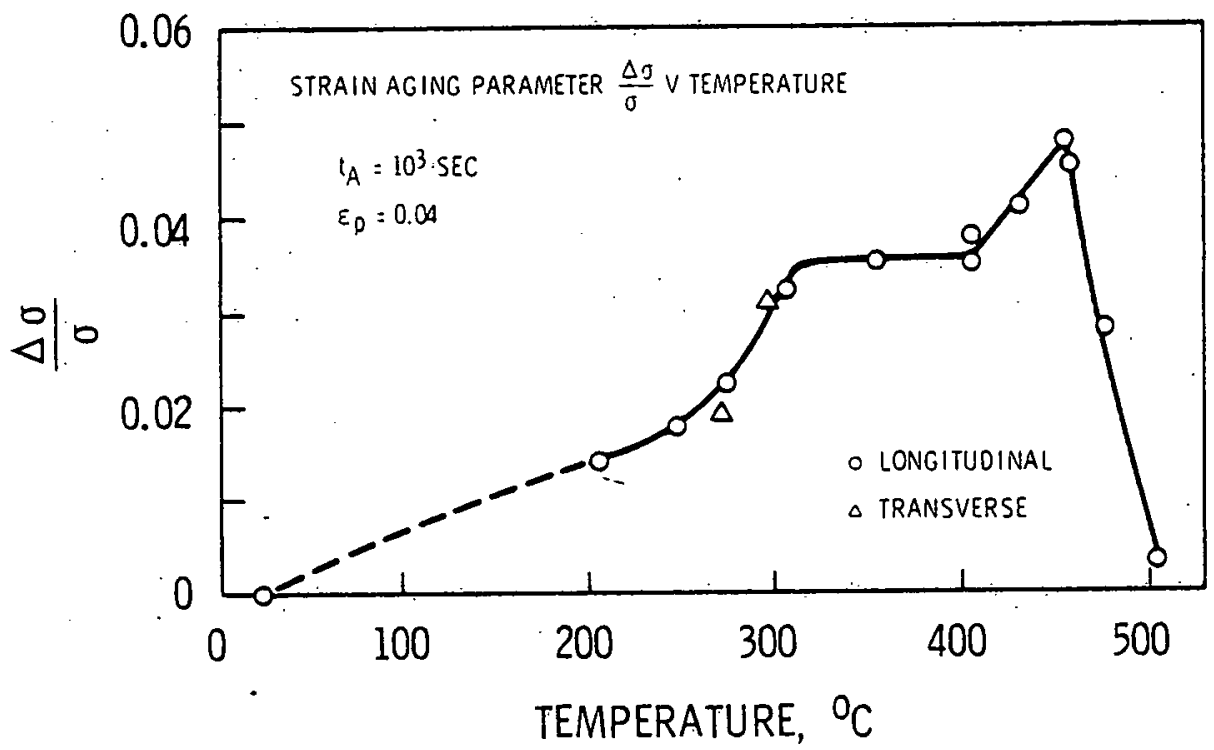

FIGURE 1a. Strain Aging Verus Temperature for Zircaloy-2 (From Reference 7)

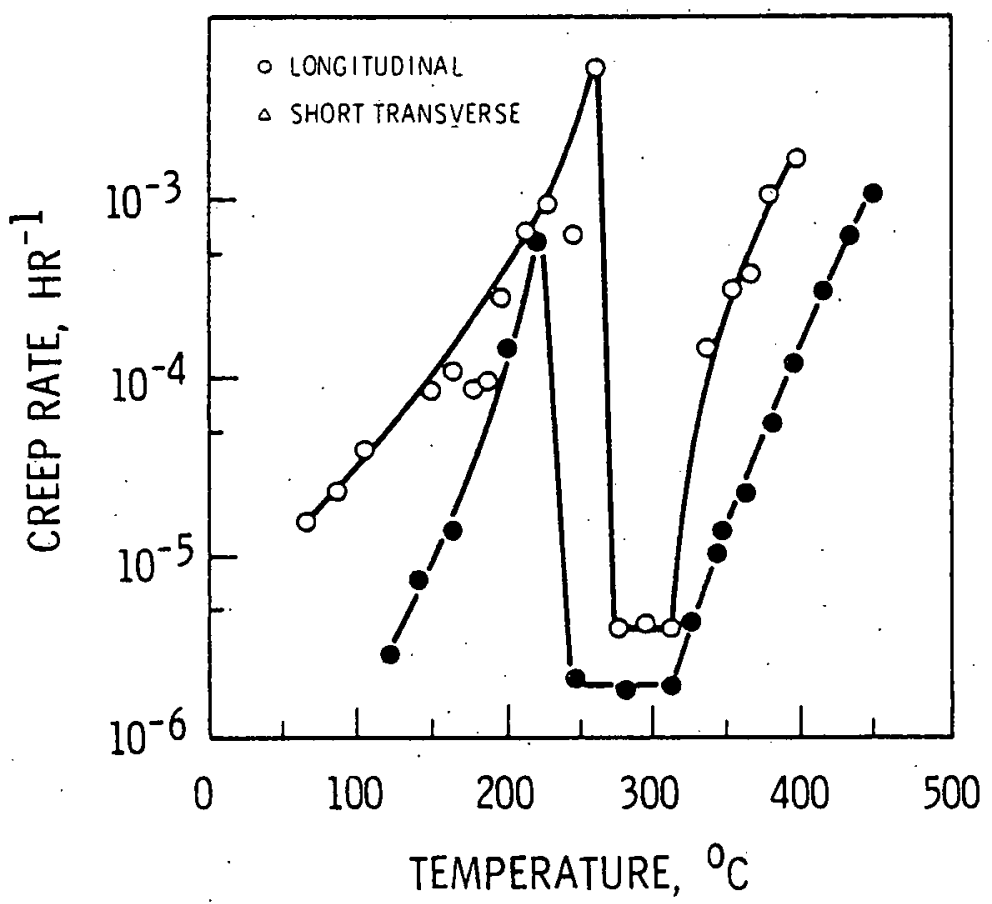

FIGURE 1b. Variation of Creep Rate of Annealed Zircaloy-2 with Temperature at a Stress of $20 \mathrm{ksi}$ (From Reference 7) 


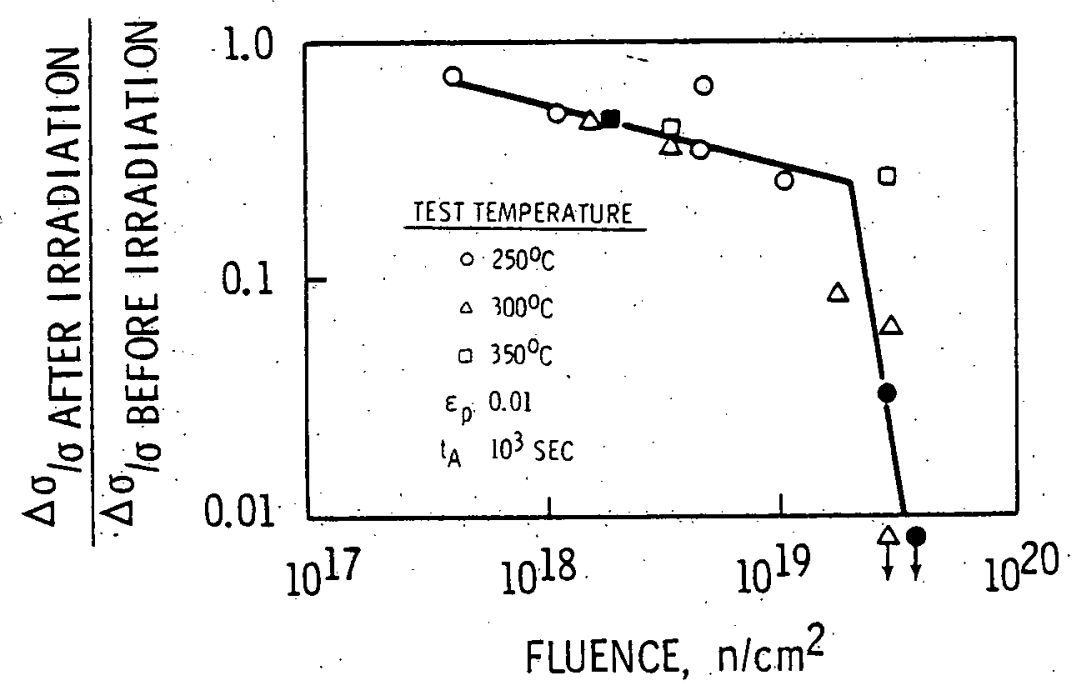

FIGURE 1. . Suppression of Strain Aging by Irradiation at a Fluence Greater than 5 E $19 \mathrm{n} / \mathrm{cm}^{2}$ (From Reference 7 )

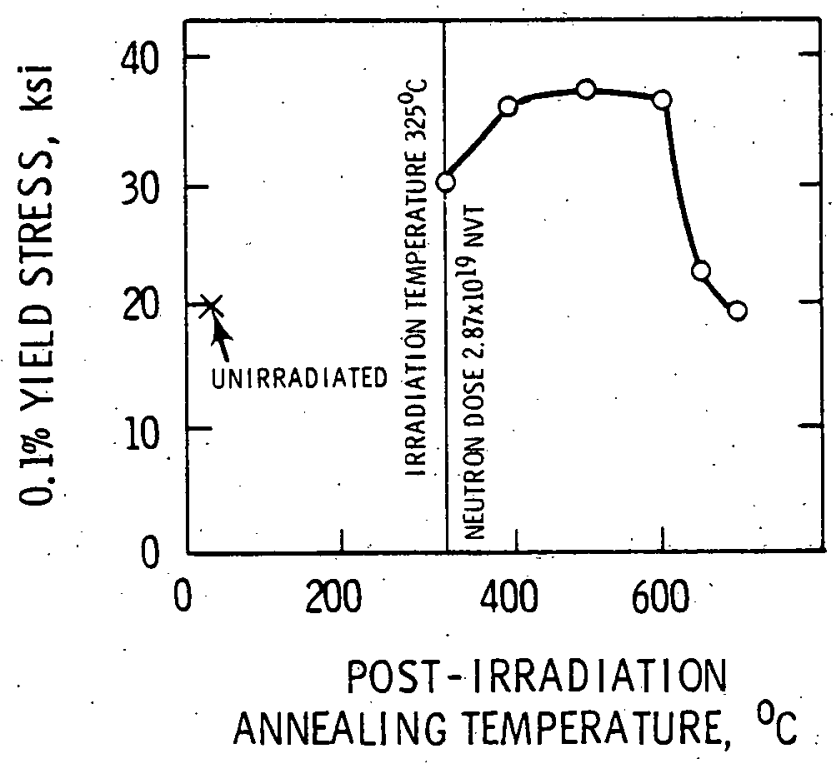

FIGURE 1d. Curve Showing $0.1 \%$ "Yield Stress of Zircaloy-2 after Postirradiation Annealing for one Hour (From Réference 7 ) 


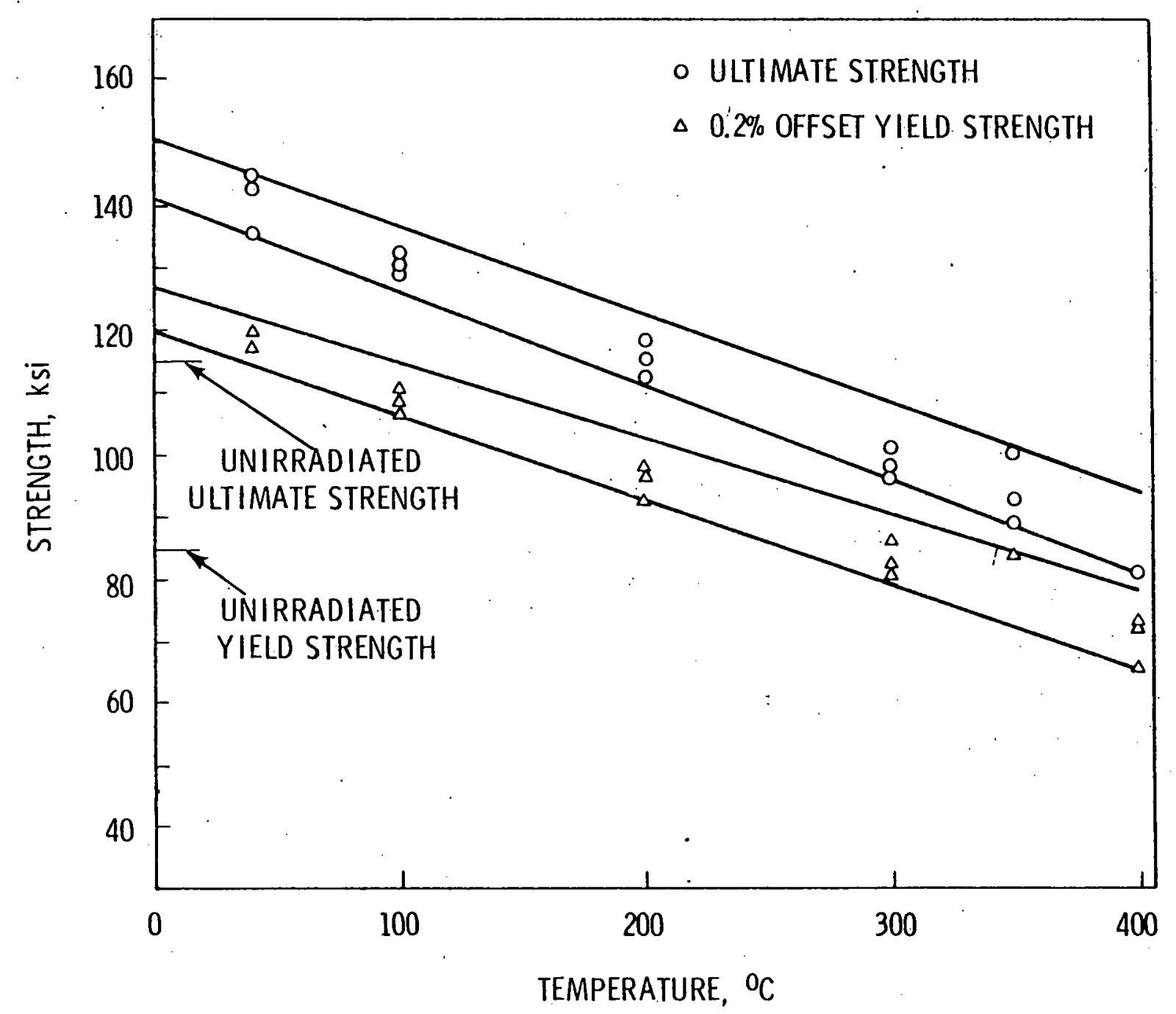

FIGURE 2. Effect of Temperature on the Strength of Irradiated Zircaloy Fuel-Rod Tubing (From Reference 28) 


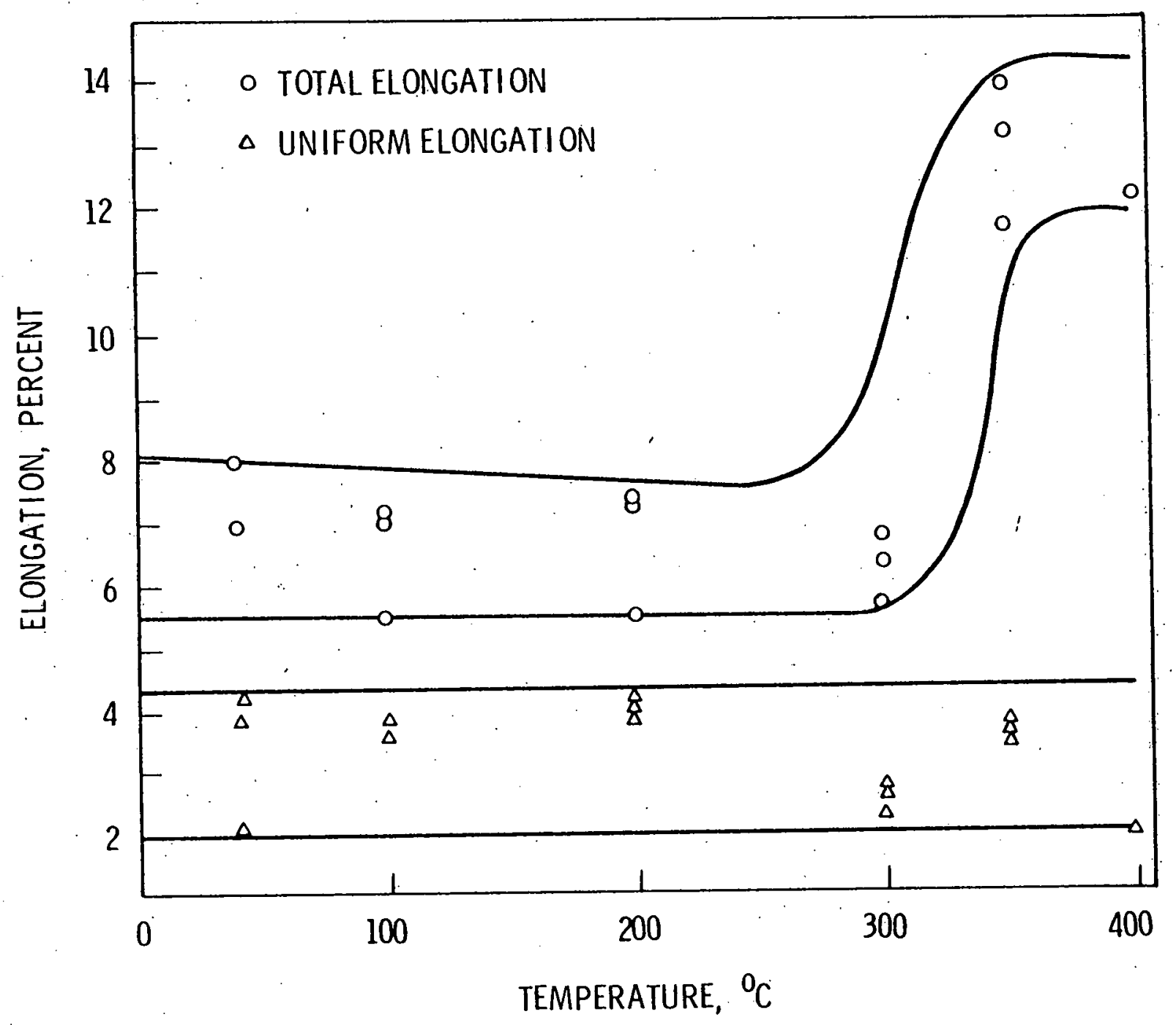

FIGURE 3. Effect of Temperature on the Ductility of Irradiated Zircaloy Fuel-Rod Tubing (From Reference 28). 


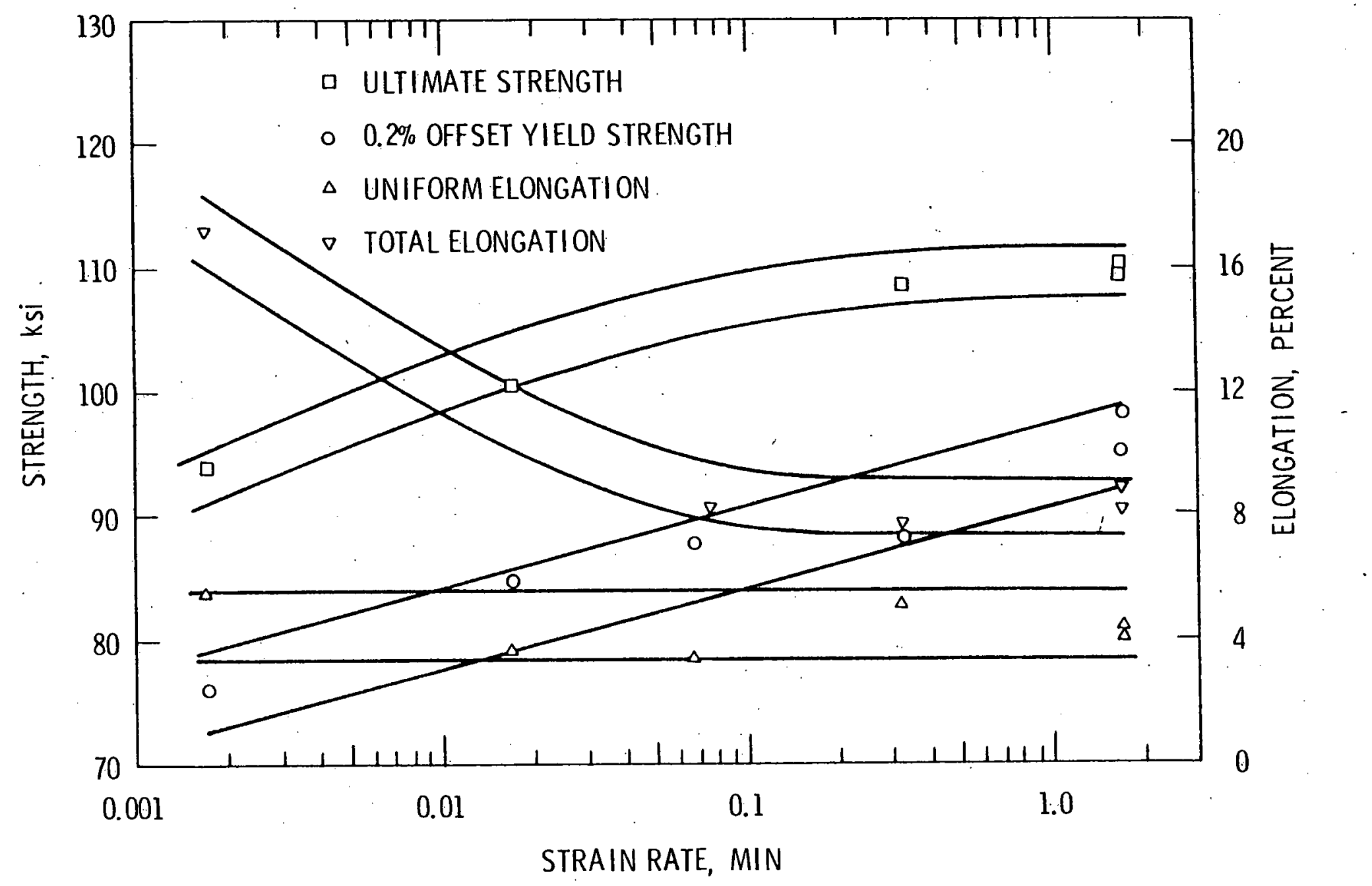

FIGURE 4. Effect of Strain Rate at $370^{\circ} \mathrm{C}$ on the Tensile Properties of Irradiated Zircaloy Fuel-Rod Tubing (From Reference 28 ) 


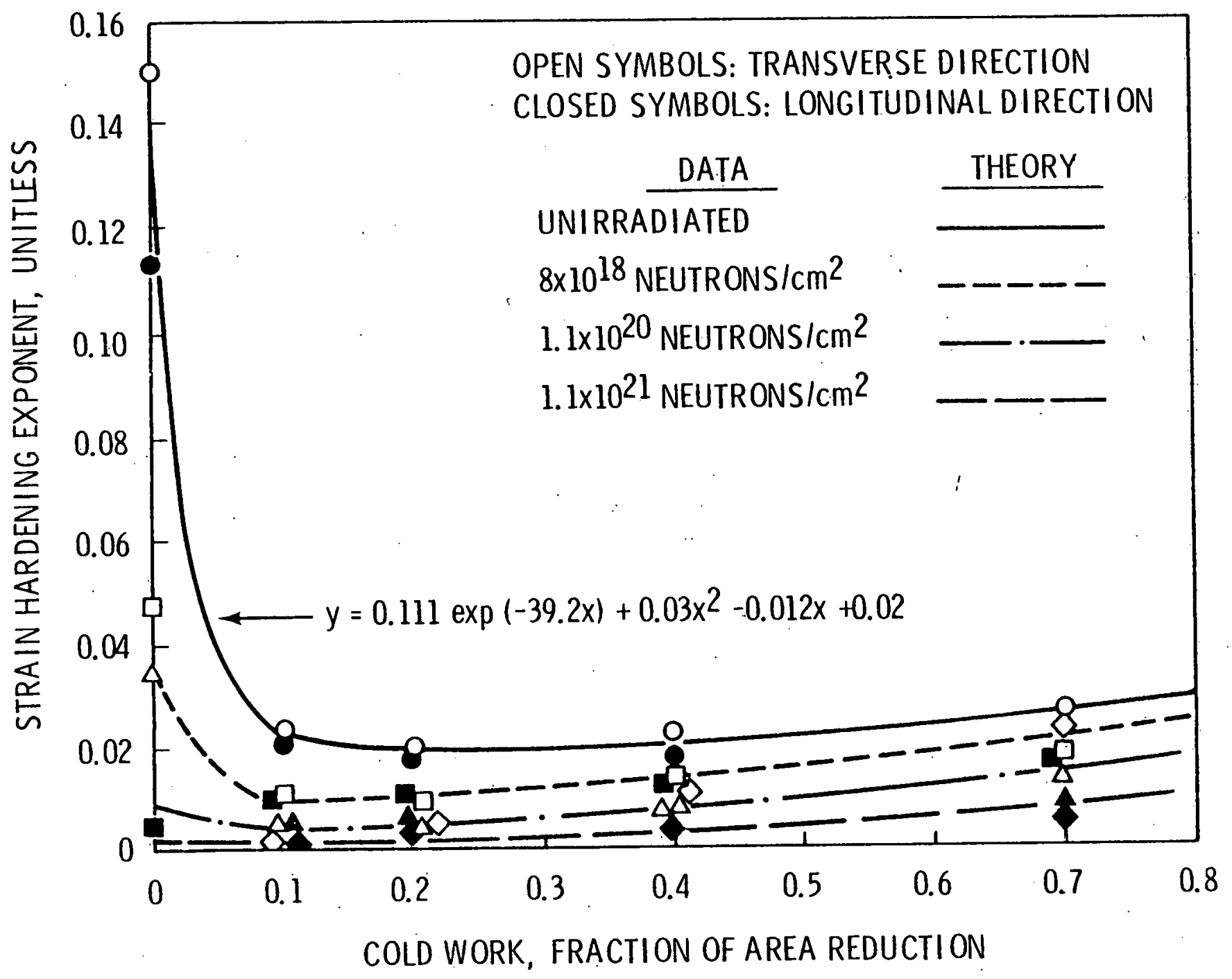

FIGURE 5. Data and Analytical Functions for Strain Hardening Coefficient as a Function of Cold Work and Irradiation at Room Temperature (From Reference 21) 


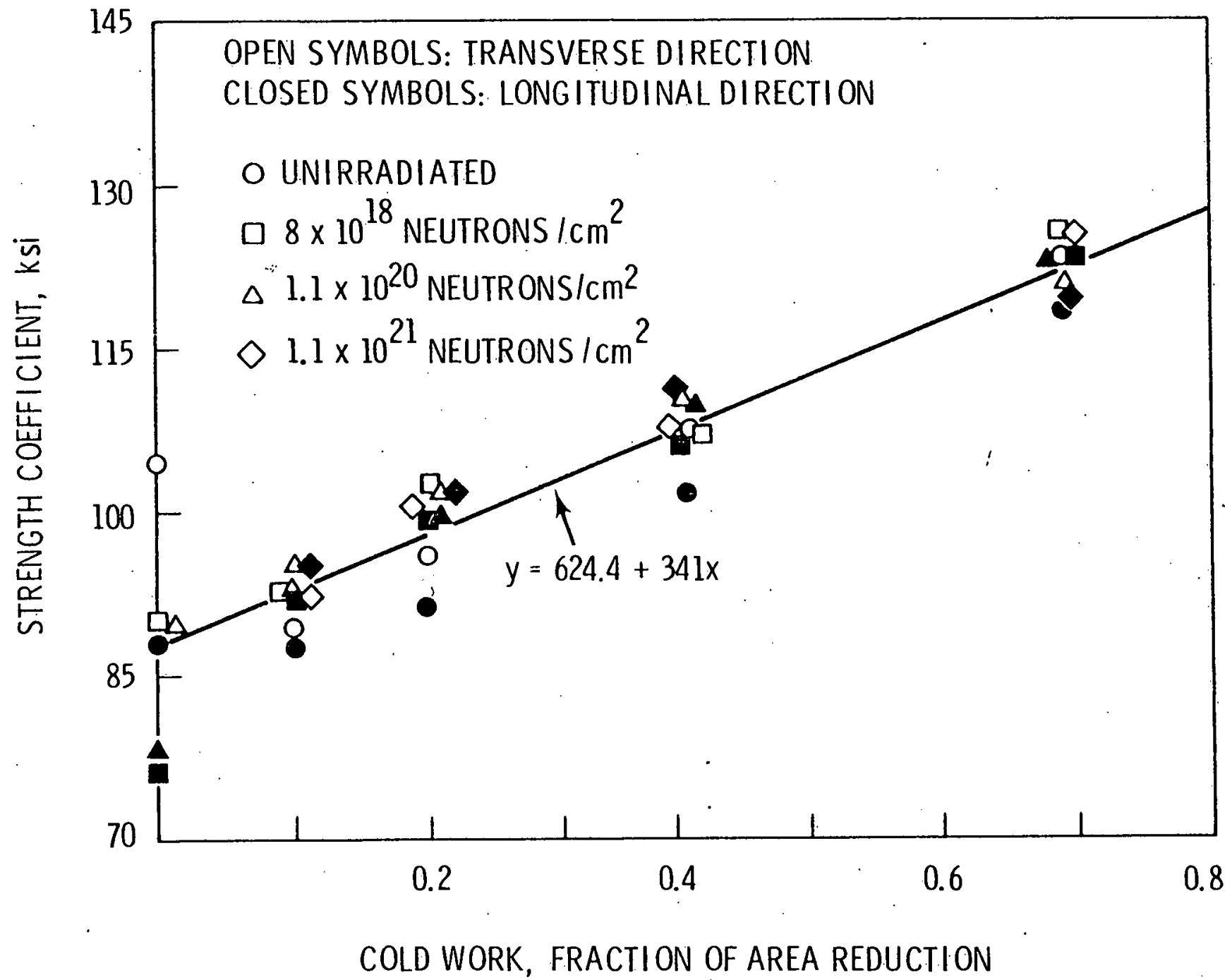

FIGURE 6. Strength Coefficient for Zircaloy-2 as a Function of Cold Work and Fluence (From Reference 21) 


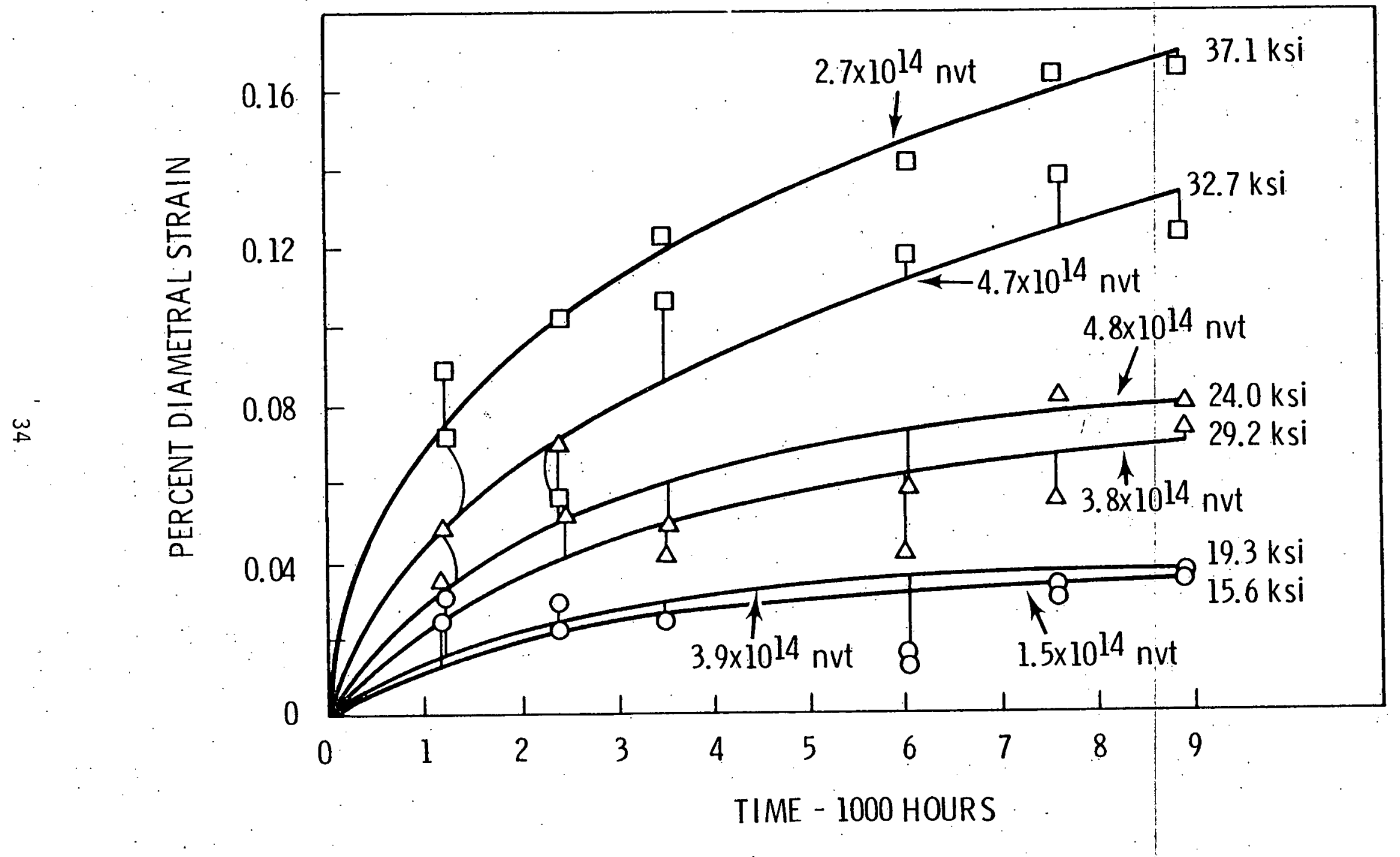

FIGURE 7. Creep Curves for Diametral Creep of Zircaloy-2 Tubes in Thermal Neutron Flux of 1.4 E13 to $1.5 \mathrm{E} 14 \mathrm{n} / \mathrm{cm}^{2} \mathrm{~s}$ at $258^{\circ} \mathrm{C}$ (From Reference 33 ) 


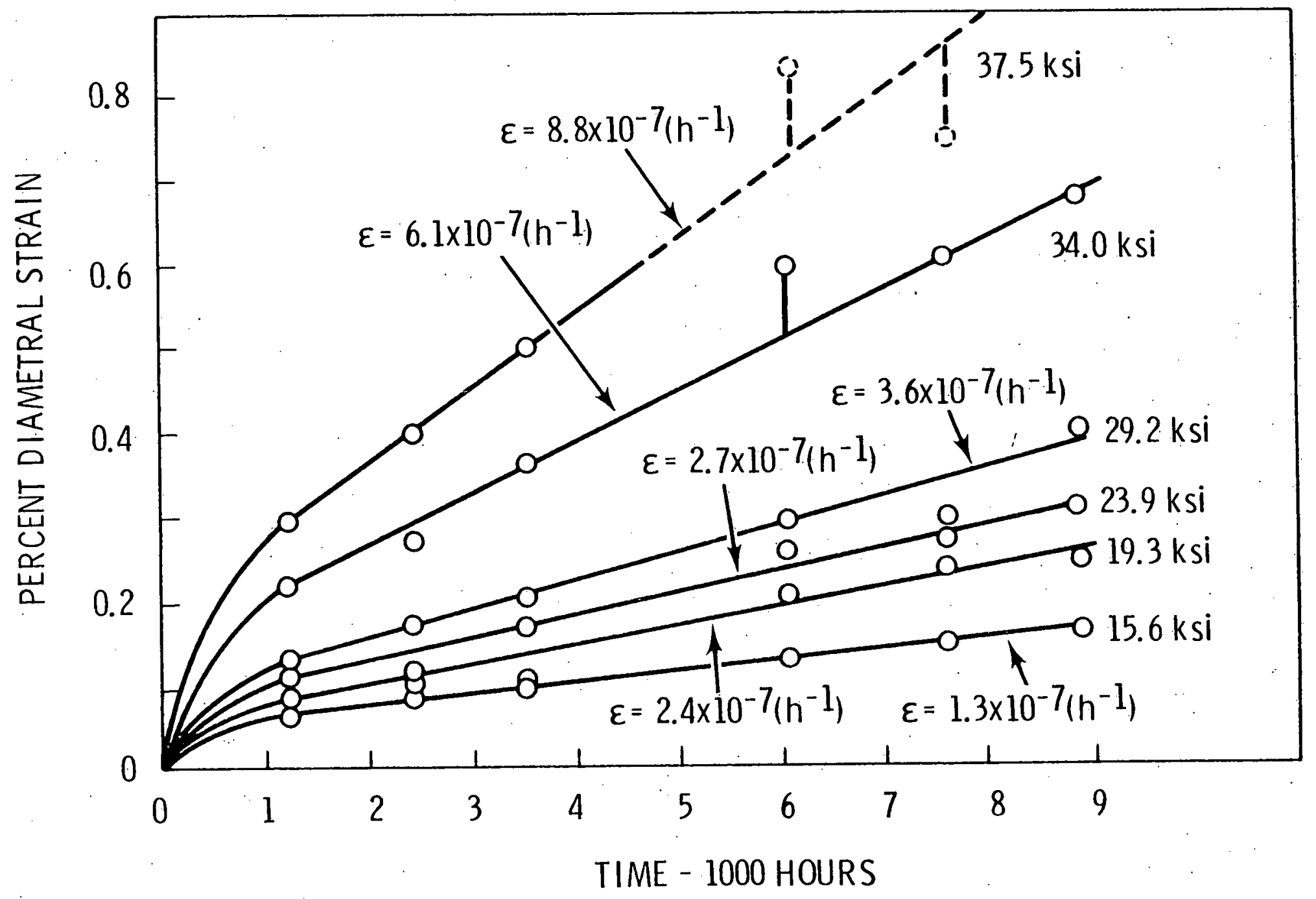

FIGURE 8. Creep Curves for Diametral Creep of Zircaloy-2 Tubes in a Fast-flux of $2.56 \mathrm{E} 13 \mathrm{n} / \mathrm{cm}^{2} \mathrm{~s}$ at $258^{\circ} \mathrm{C}$ (From Reference 33 ) 


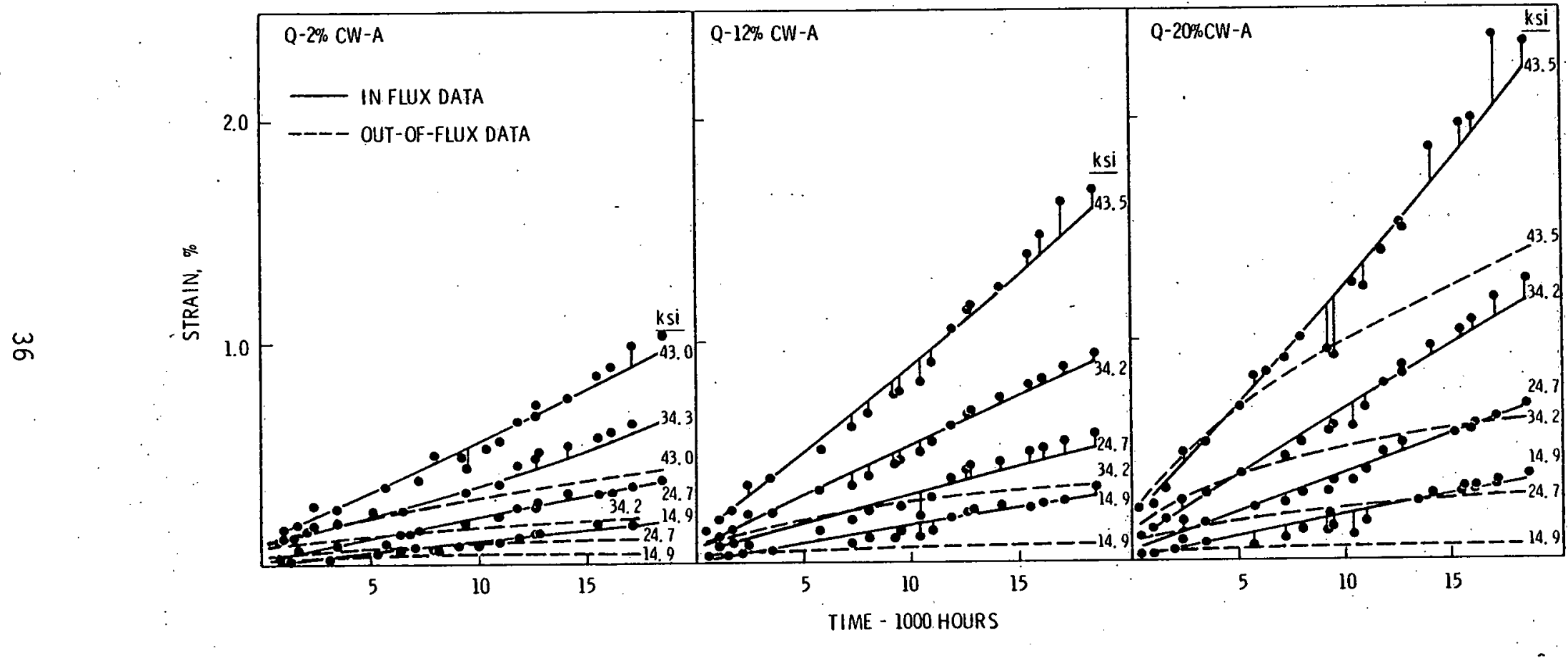

FIGURE 9. Curves for Diametral Creep of Quenched, Cold-Drawn and Aged Zr-2.5\% Nb, Out-of-Flux and in a Fast Neutron Flux $\left(2.3 \mathrm{E} 13 \mathrm{n} / \mathrm{cm}^{2} \mathrm{sec}\right) 1 \mathrm{MeV}$ at $295^{\circ} \mathrm{C}$ (From Reference 34 ) 


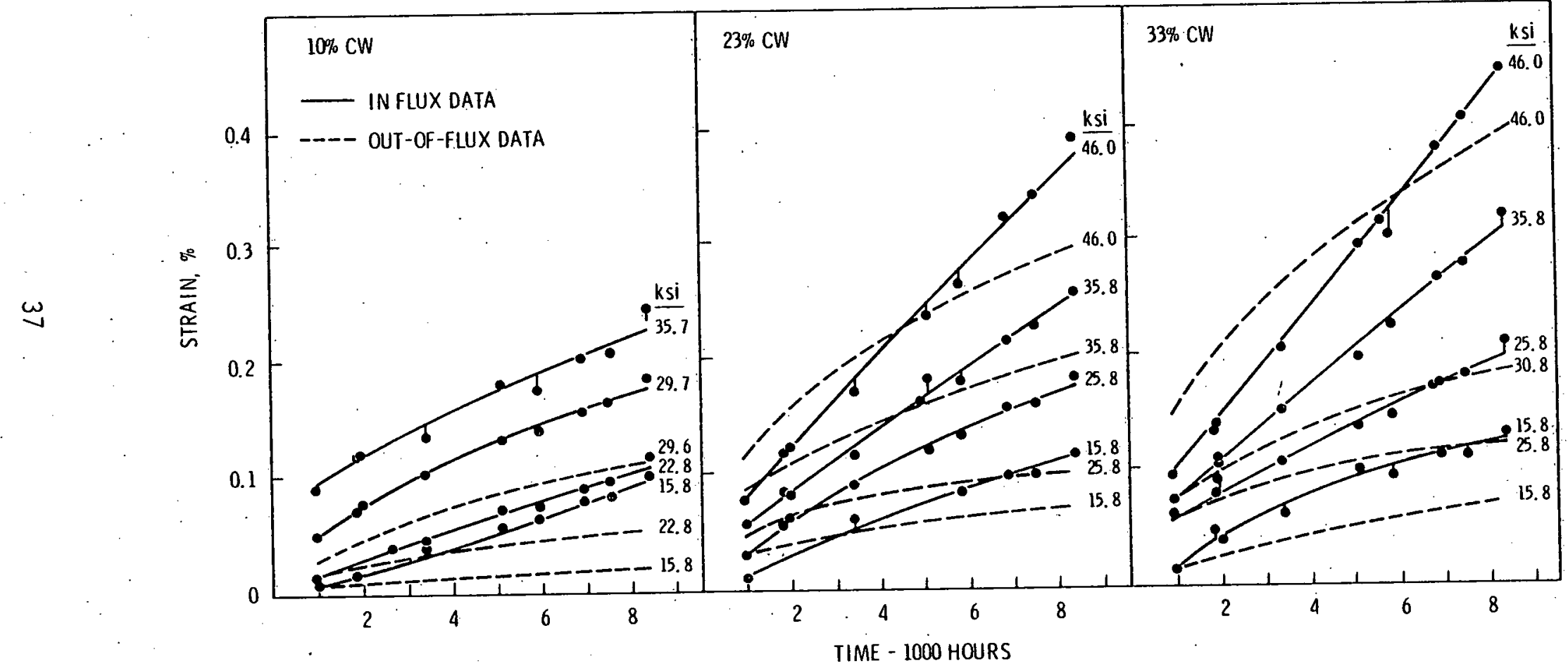

FIGURE 10. Curves for Diametral Creep of Cold Drawn $\mathrm{Zr}-2.5 \% \mathrm{Nb}$, Out-of-Flux and in a Fast Neutron Flux (1.9 E13 $\mathrm{n} / \mathrm{cm}^{2} \mathrm{sec}$ ) $1 \mathrm{MeV}$ at $29^{\circ} \mathrm{C}$ (From Reference 34 ) 


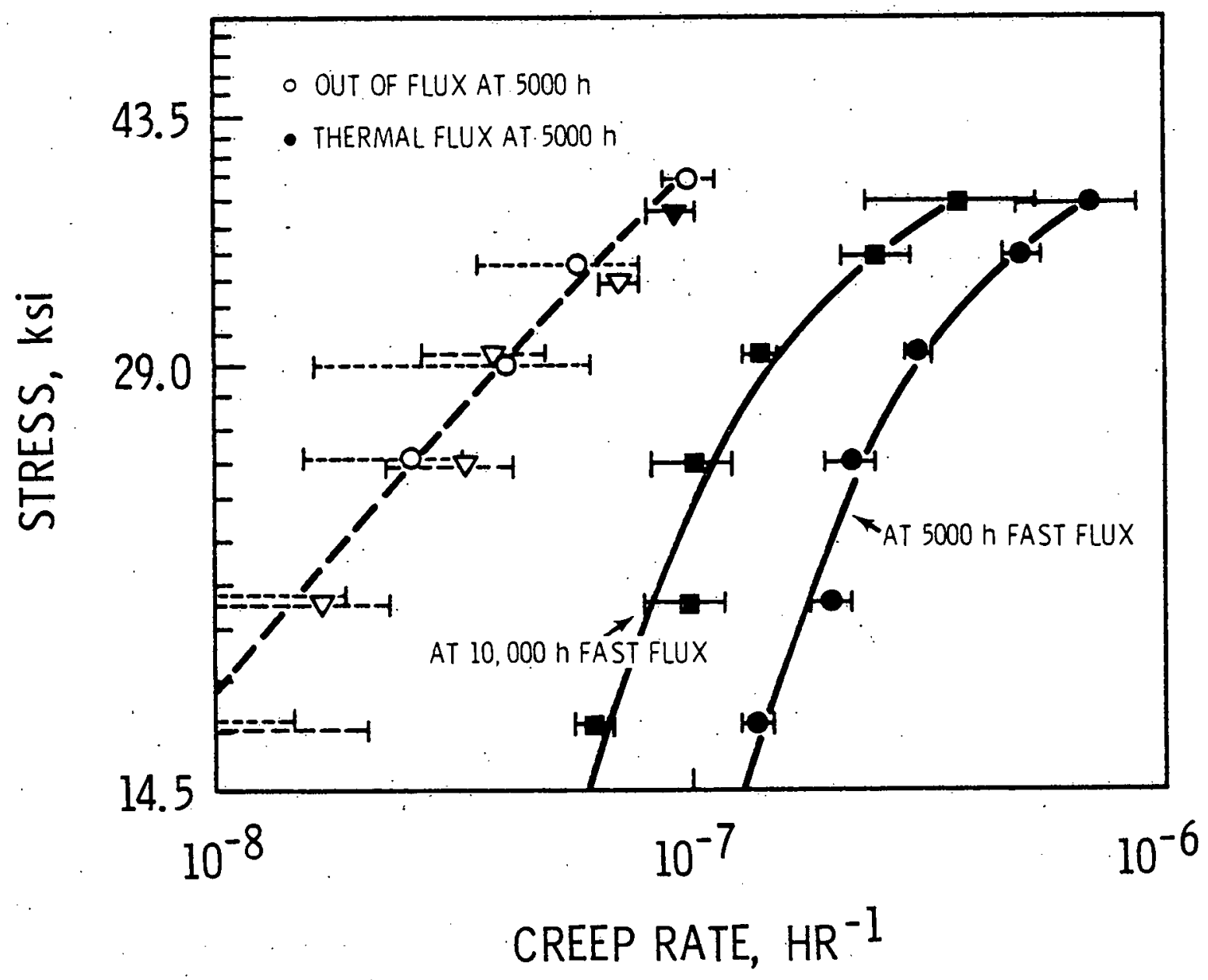

FIGURE 11. Creep Rates of $20 \%$ Cold Drawn Zircaloy-2 Specimens at $263^{\circ} \mathrm{C}$ in-and out-of-Neutron Fluxes

(From Reference 35 ) 


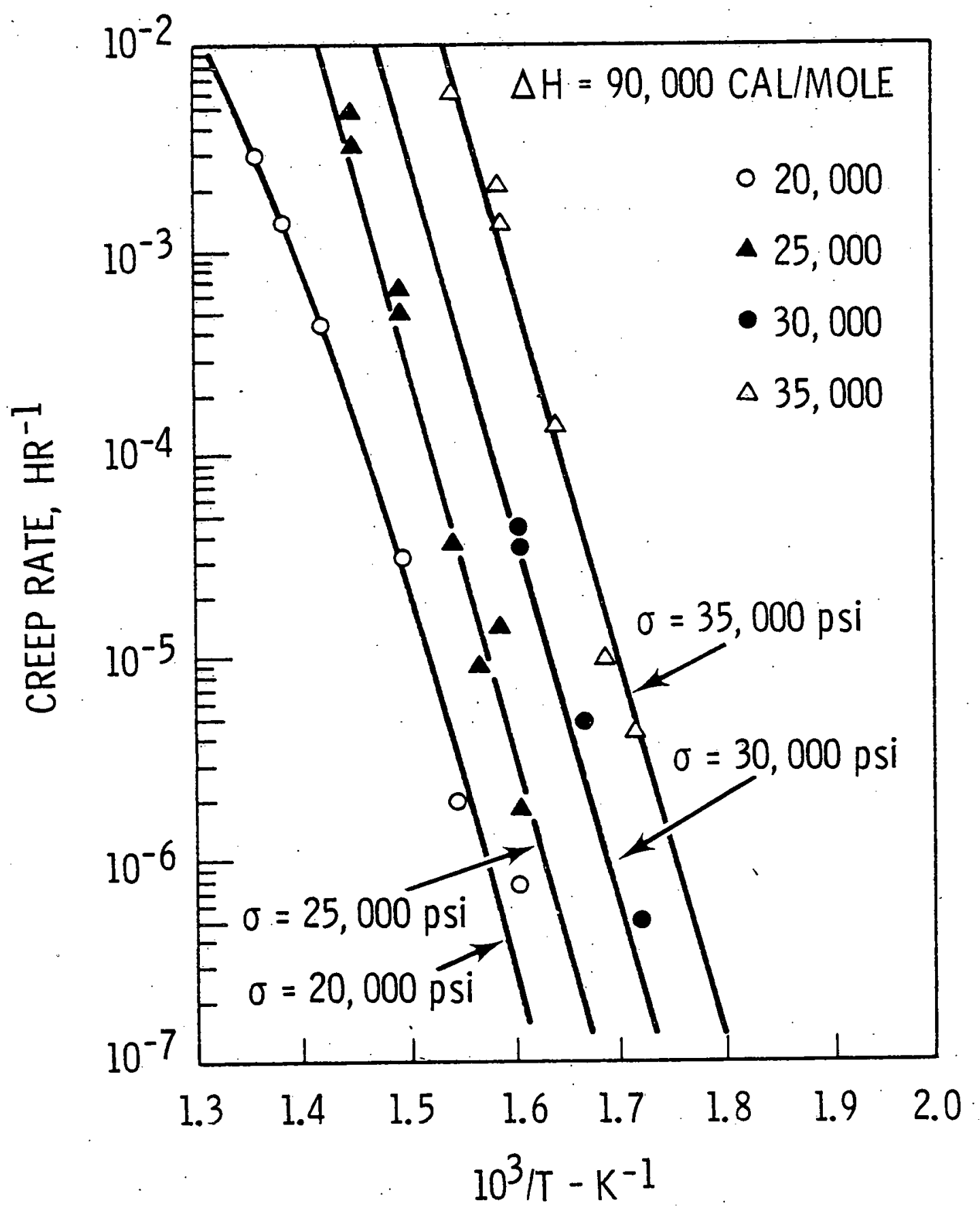

FIGURE 12. Arrhenius Plot of In-Reactor Creep Data (From Reference 36) 


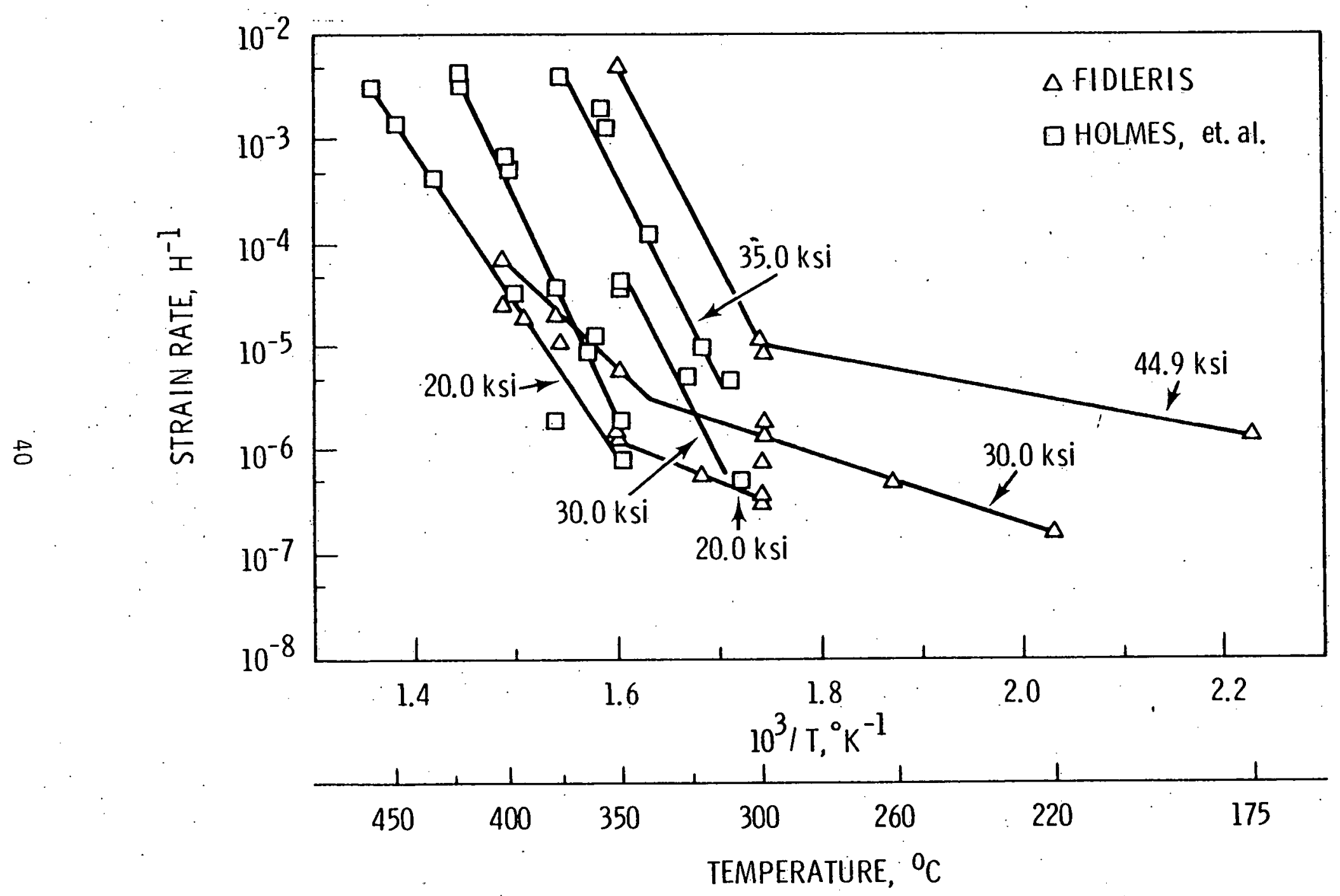

FIGURE 13. In-Reactor Creep of Cold-Worked Zircaloy-2 Showing the Effect of Temperature on Creep Rate (From Reference 37) 


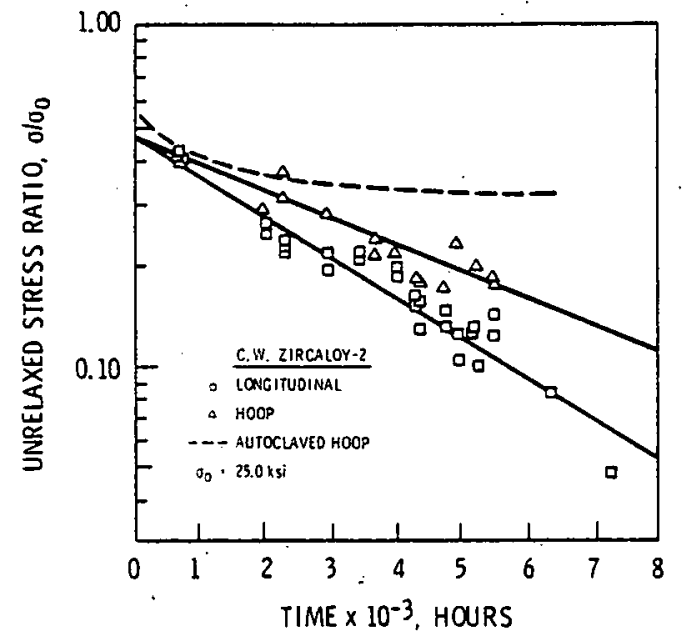

FIGURE 14a. Unrelaxed Stress Ratio as a Function of Time for ColdWorked Zircaloy-2 Showing the Behavior of Longitudinal and Hoop Specimens In-Reactor at $239^{\circ} \mathrm{C}$ and Comparing the Data for Hoop Specimens with Those from Autoclave Tests at $300^{\circ} \mathrm{C}$ (From Reference 38)

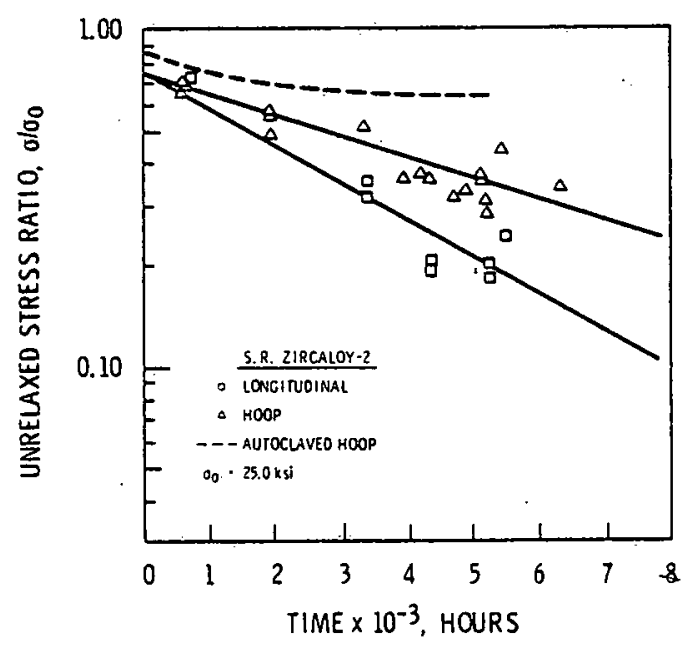

FIGURE 14c. Unrelaxed Stress Ratio as a Function of Time for StressRelieved Zircaloy-2 Showing the Behavior of Longitudinal and Hoop Specimens In-Reactor at $293^{\circ} \mathrm{C}$ and Comparing the Data for Hoop Specimens with Those from Autoclave Tests at $300^{\circ} \mathrm{C}$ (From Reference 38 )

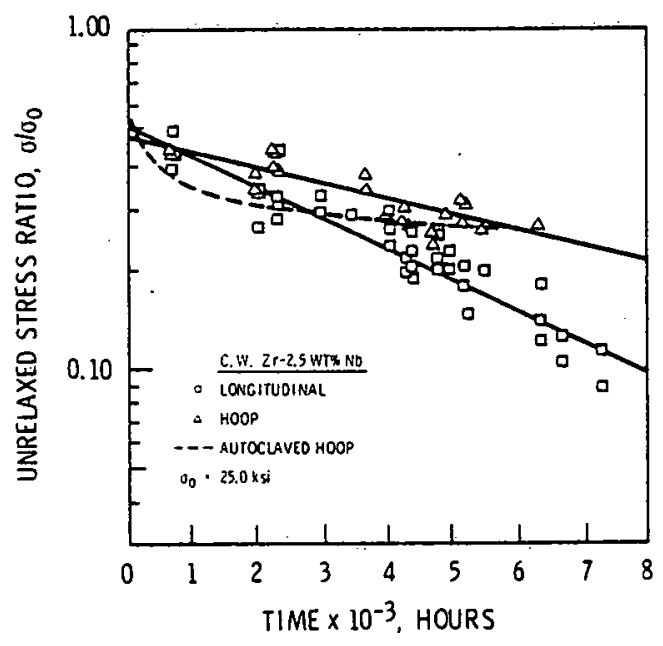

FIGURE 14b. Unrelaxed Stress Ratio as a Function of Time for ColdWorked $\mathrm{Zr}-2.5 \mathrm{wt} \% \mathrm{Nb}$ Showing the Behavior of Longitudinal and Hoop Specimens In-Reactor at $293^{\circ} \mathrm{C}$ and Comparing the Data for Hoop Specimens with Those from Autoclave Tests at $300^{\circ} \mathrm{C}$ (From Reference 37 )

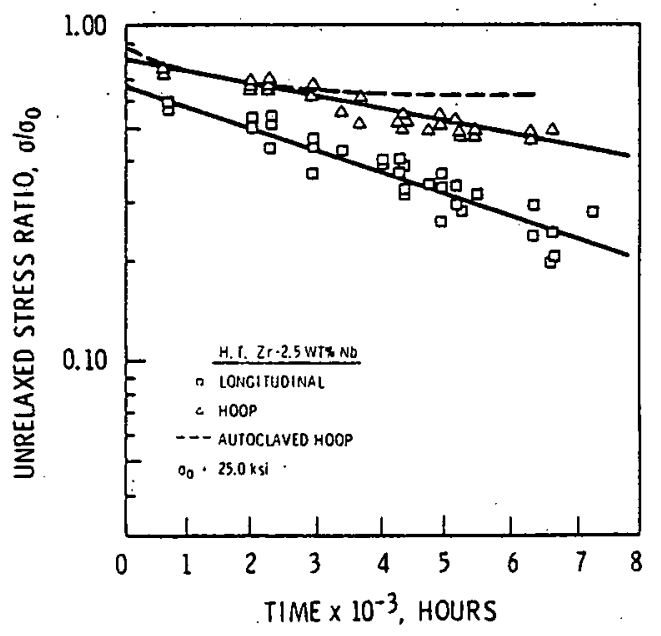

FIGURE 14d. Unrelaxed Stress Ratio as a Function of Time for HeatTreated $\mathrm{Zr}-2.5 \mathrm{wt} \% \mathrm{Nb}$ Showing the Behavior of Longitudinal and Hoop Specimens In-Reactor at $293^{\circ} \mathrm{C}$ and Comparing the Data for Hoop Specimens with Those from Autoclave Tests at $300^{\circ} \mathrm{C}$ (From Reference 38) 


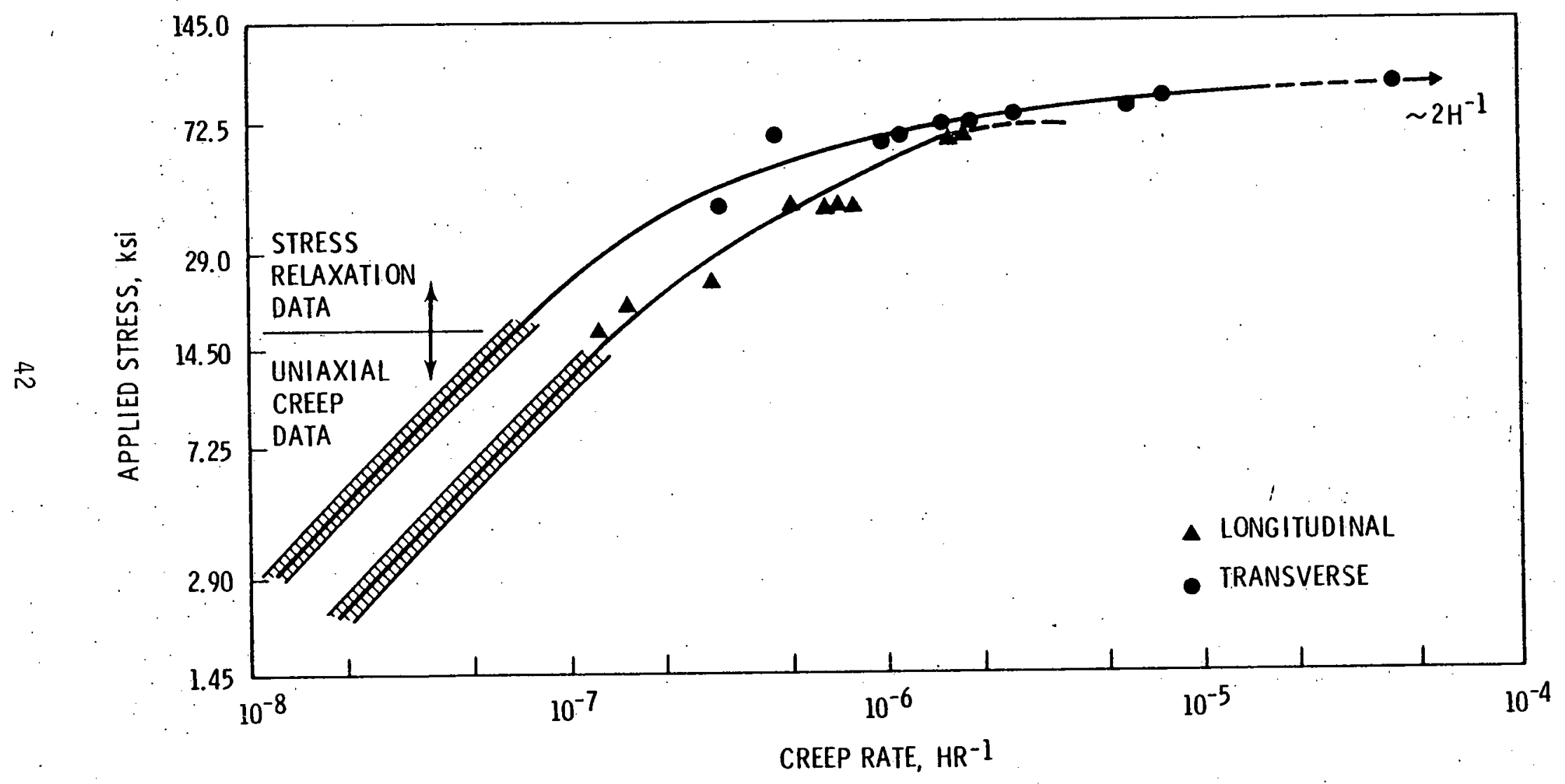

FIGURE 15. Stress Dependence of the In-Flux Creep Rate for Cold-Worked Zr 2.5 wt\% Nb (From Reference 39) 


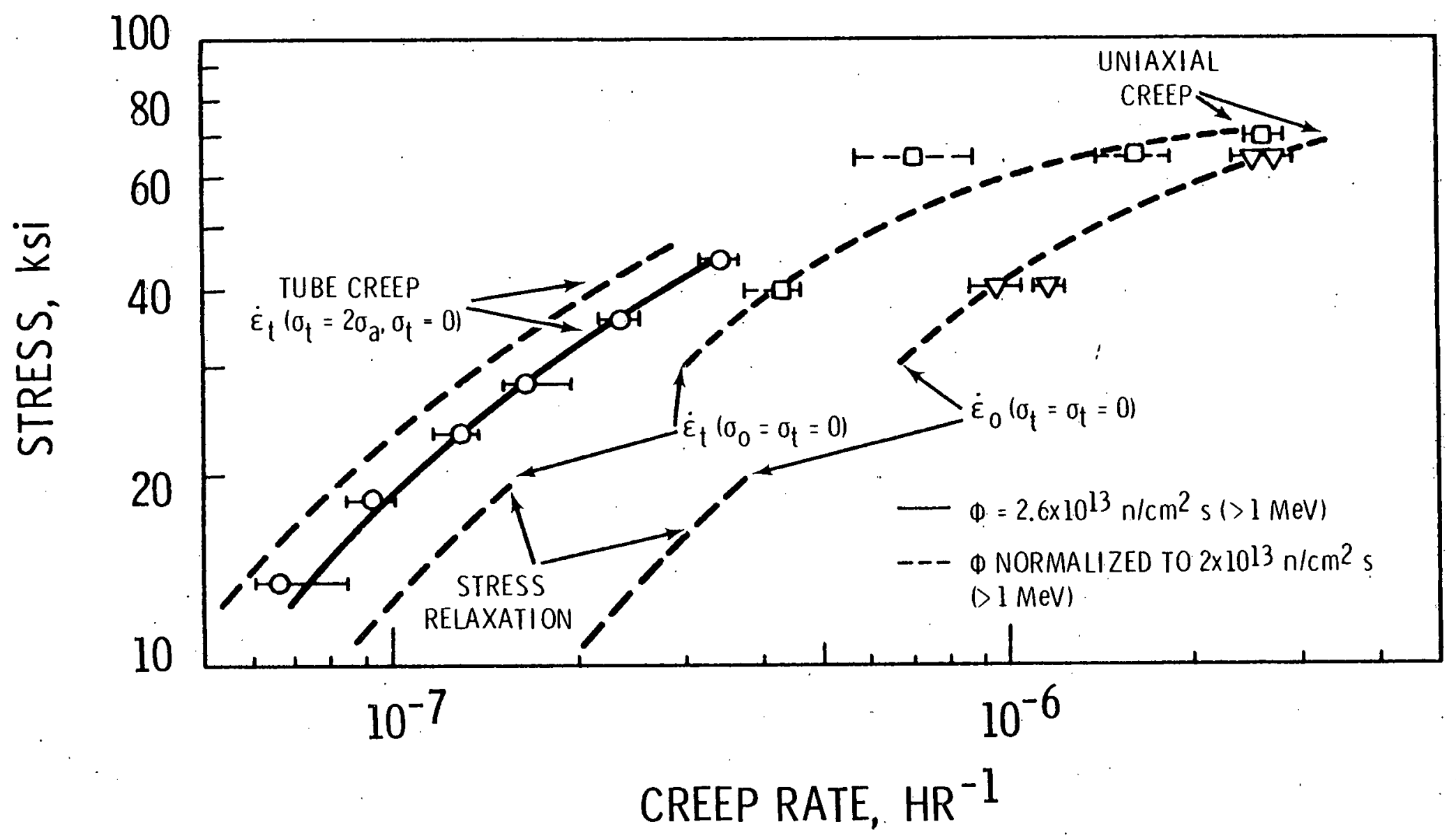

FIGURE 16. Stress Versus Creep Rate Results for Zr-2.5 wt\% Nb from StressRelaxation, Uniaxial Creep and Tube Tests at $285^{\circ} \mathrm{C}$ (From Reference 40) 


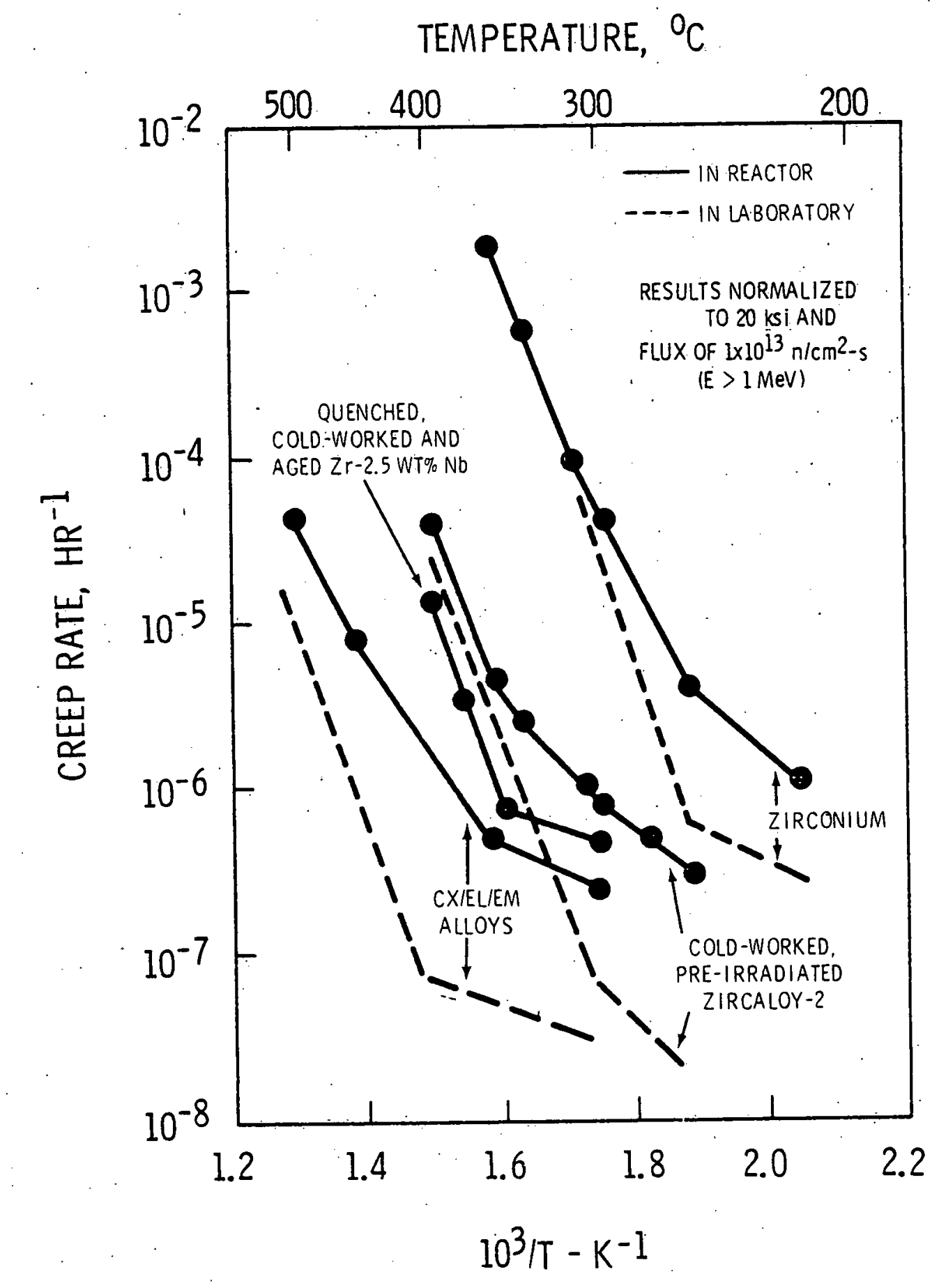

FIGURE 17: Effect of Alloying on In-Reactor Creep (From Reference 30) 


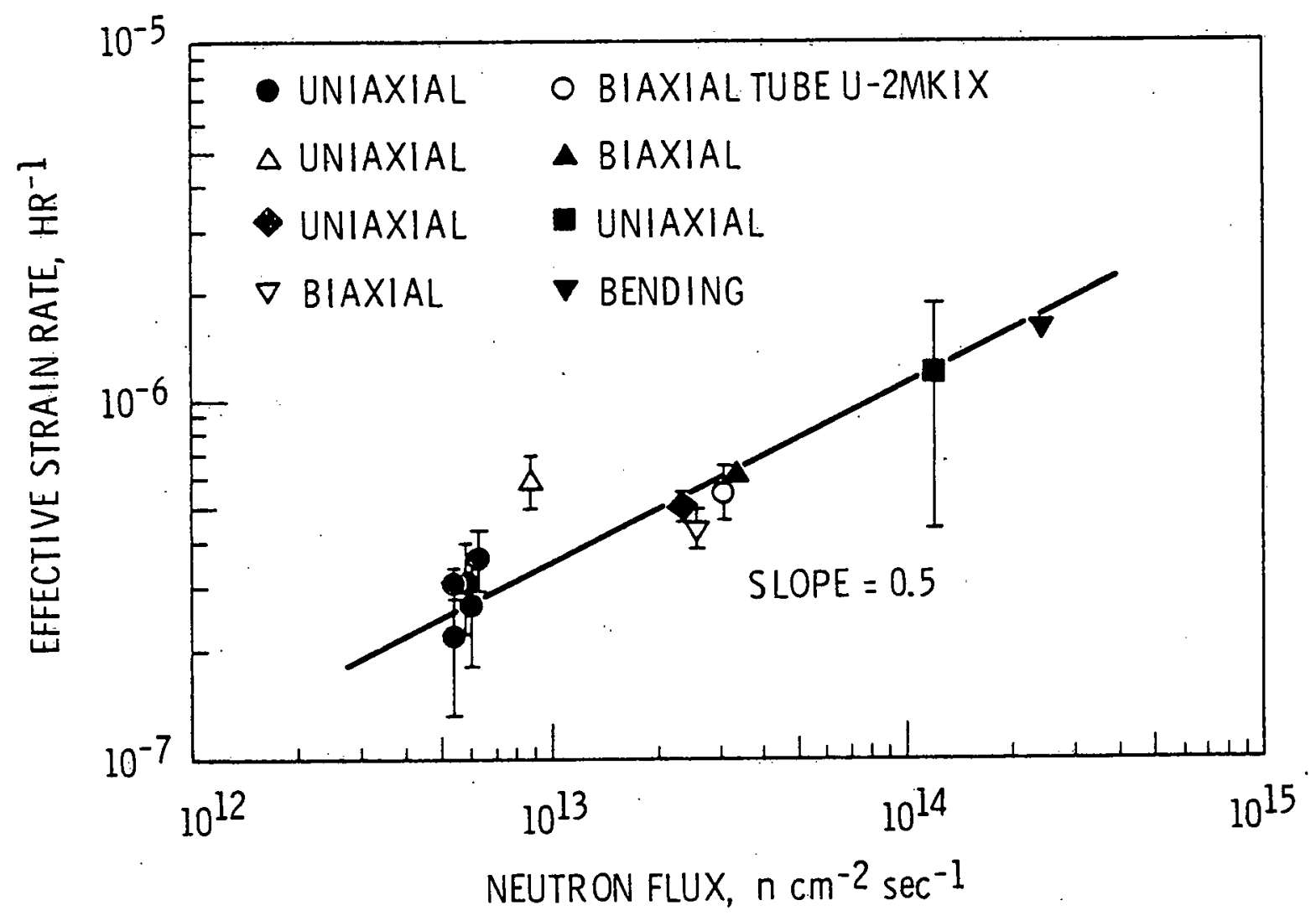

FIGURE 18. Effect of Neutron Flux on Creep Rate of ColdWorked Zircaloy Normalized to an Effective Stress of 20,000 psi and $300^{\circ} \mathrm{C}$. The Creep Rates Plotted Represent the Total Effective Creep Rate Less the Effective Creep Rate Measured in Tests on Unirradiated Specimens (From Reference 29) 


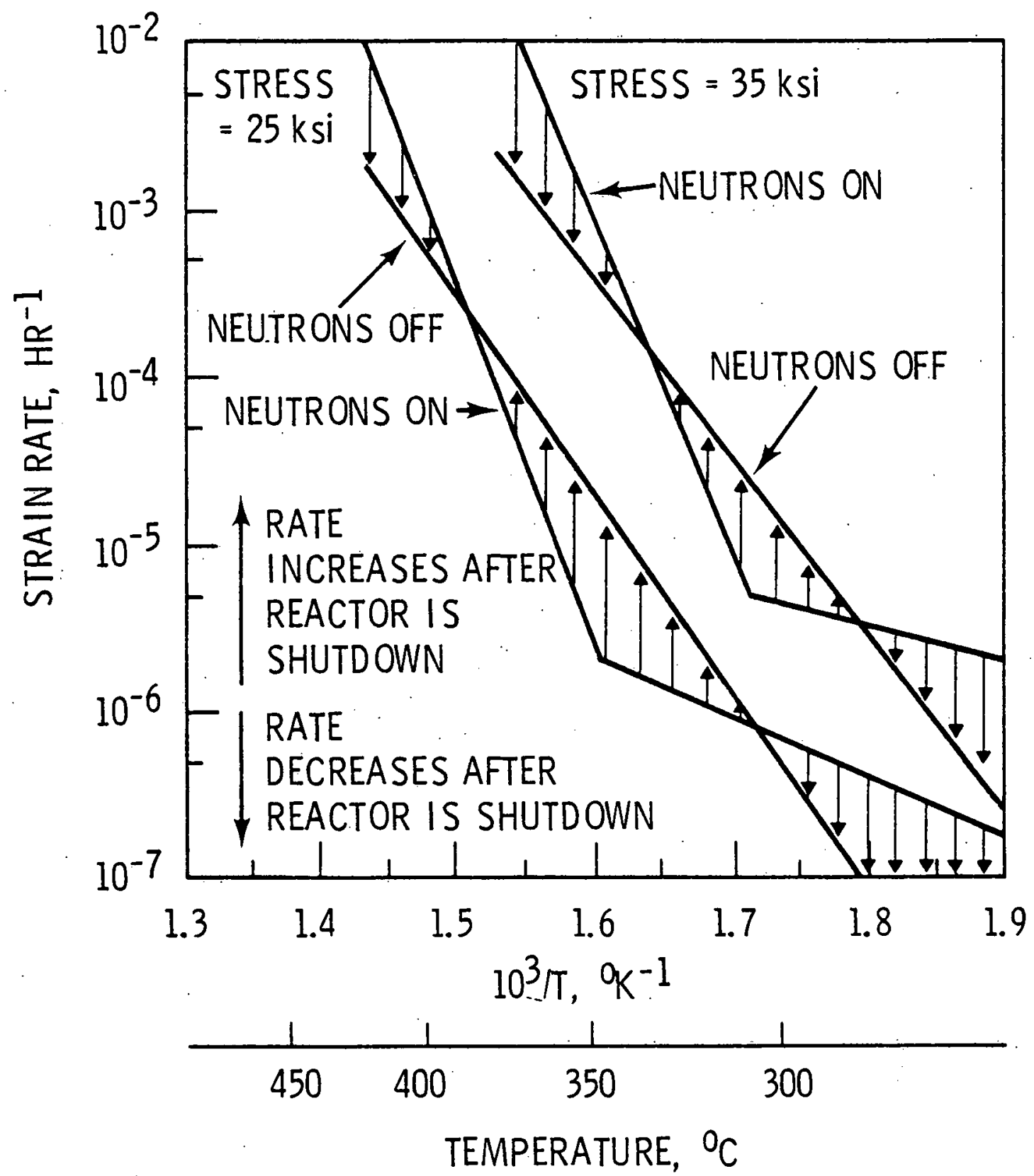

FIGURE 19. In-Reactor Creep of Cold-Worked Zircaloy-2

Showing Effect of Fast Neutron Flux on Creep Rate (From Reference 29, 37) 


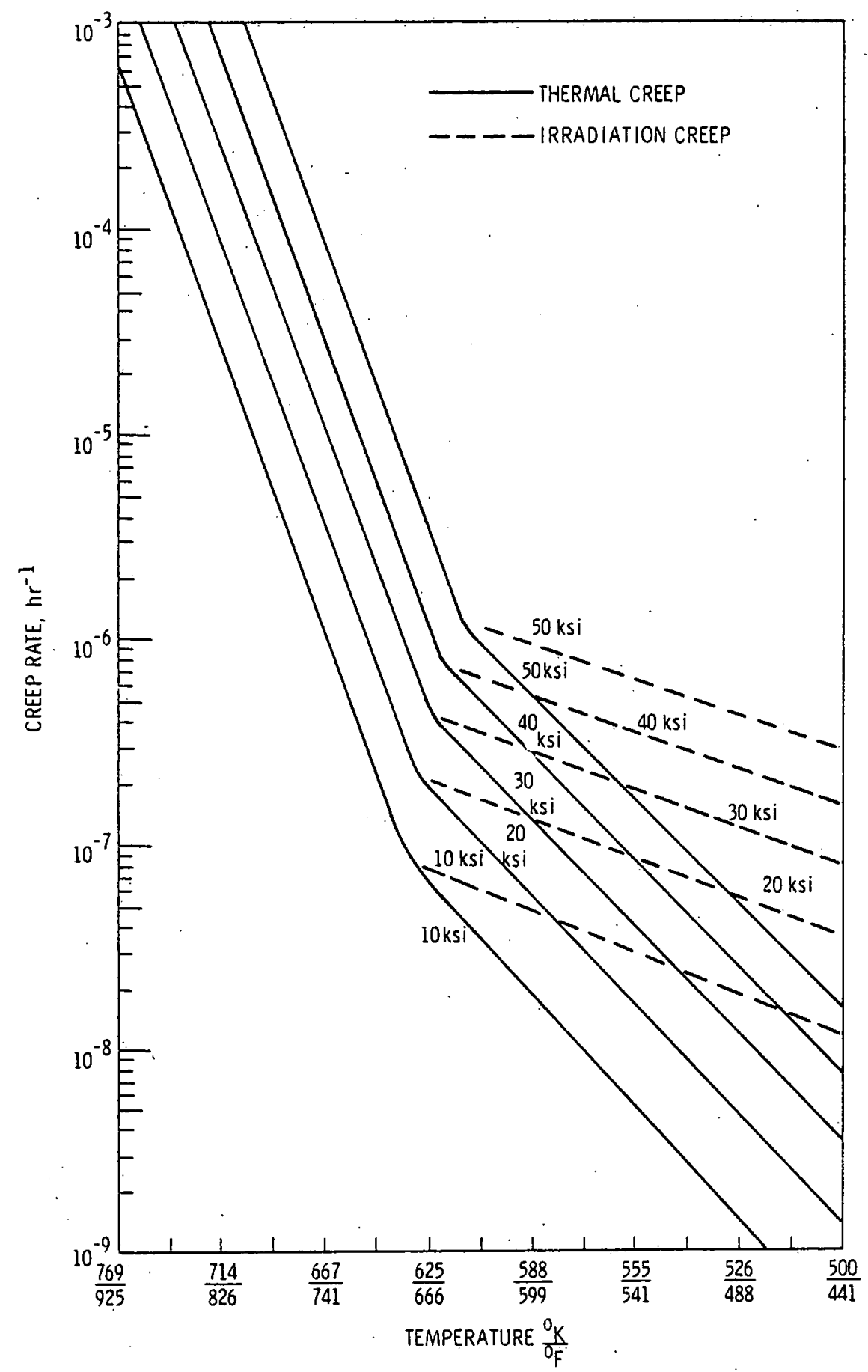

FIGURE 20. Calculated Creep Rate as a Function of Irradiation Temperature for a Flux of $6.0 \mathrm{E} 12 \mathrm{n} / \mathrm{cm}^{2} \mathrm{~s}$ (From Reference 41 ) 


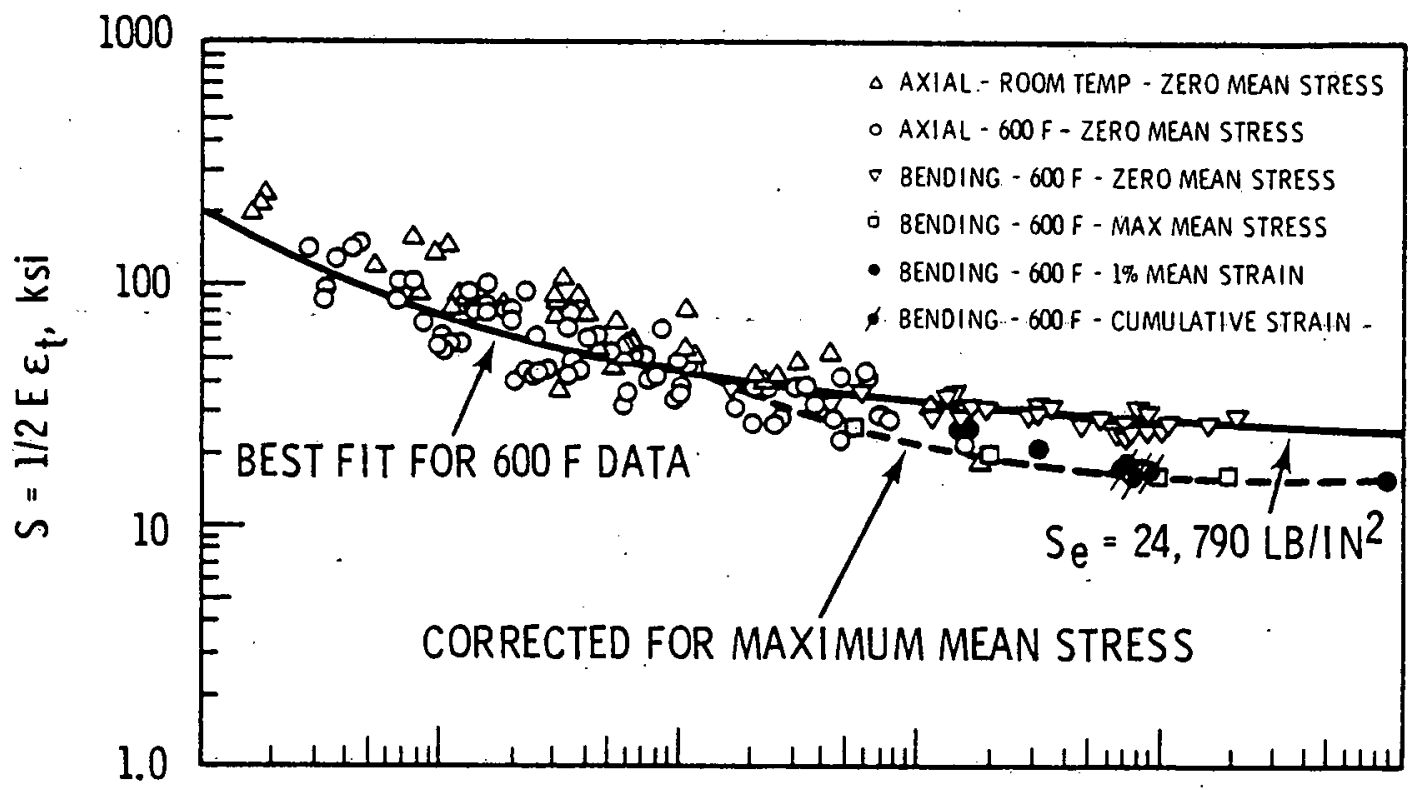

FIGURE 21a. Fatigue Data on Unirradiated Zircaloy-2 (From Reference 52).

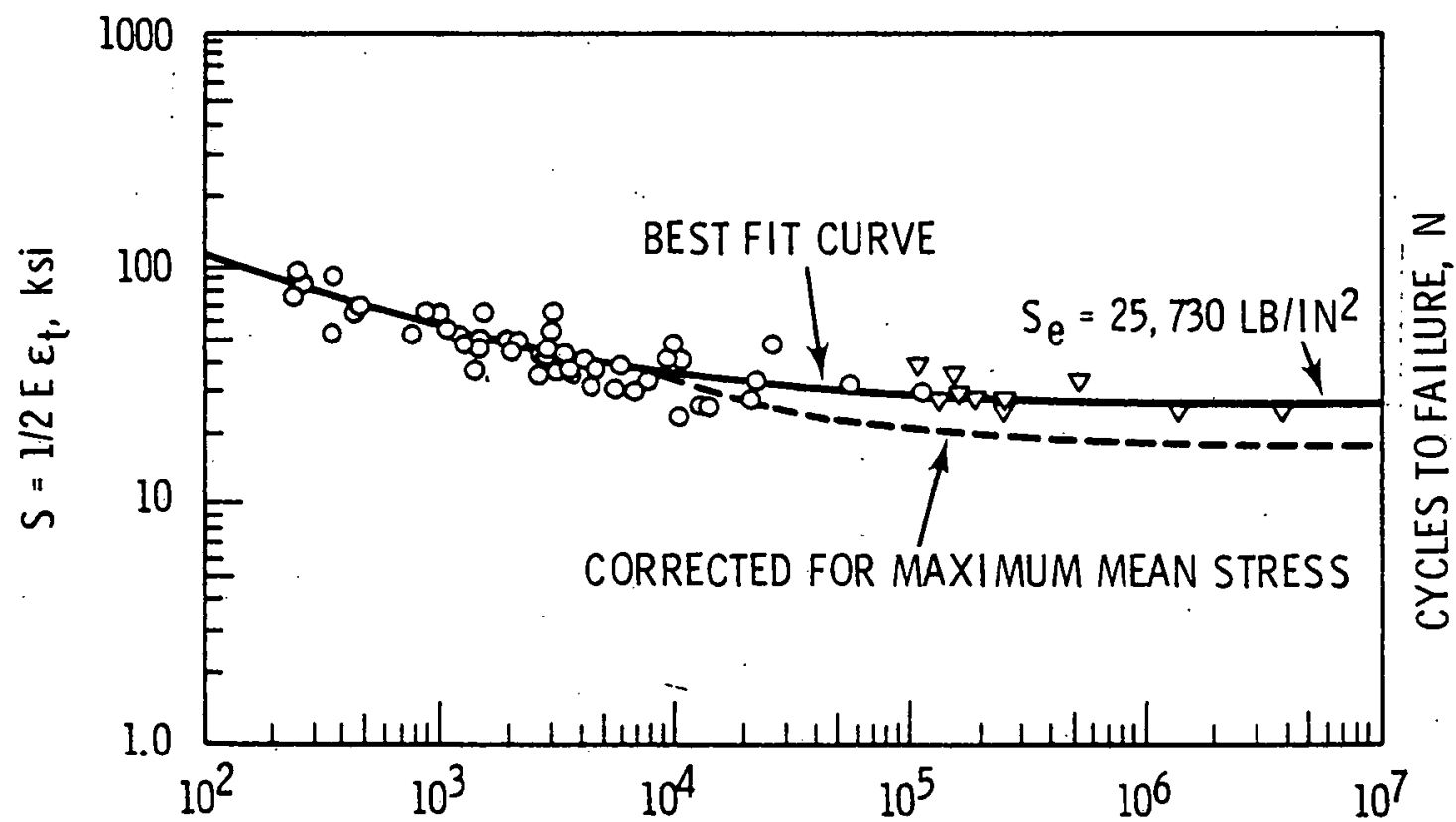

FIGURE 21b. Fatigue Data on Irradiated Zircaloy-2 (1.5 x E21 to $5.5 \times E 21 \mathrm{n} / \mathrm{cm}^{2} \mathrm{~s}>0.625 \mathrm{MeV}$ ) (From Reference 52) 


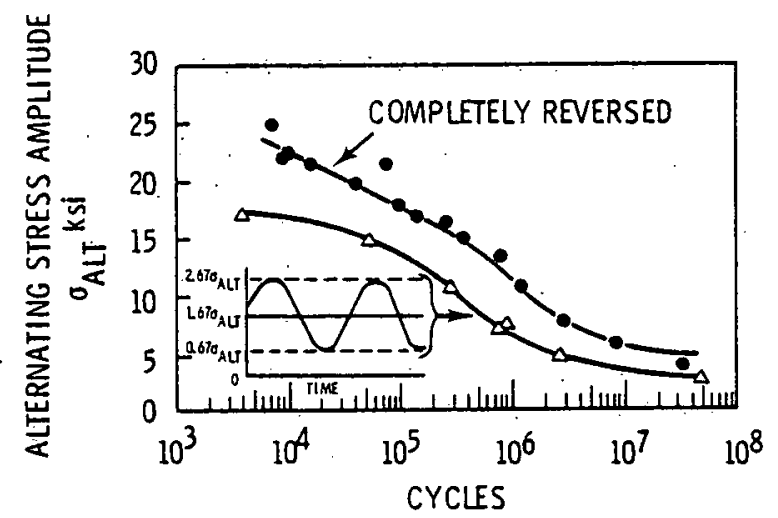

FIGURE 22a. Effect of Mean Stress on Fatigue Life (From Reference 52)

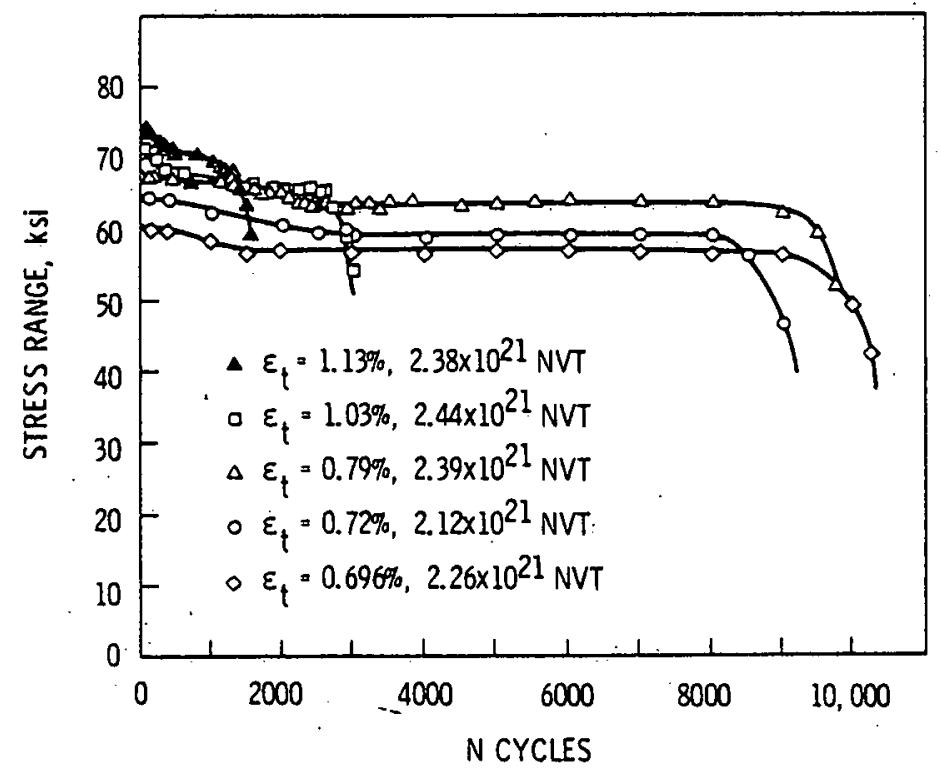

FIGURE 22b. Axial Strain Fatigue Data for Irradiated AlphaAnnealed Zircaloy-2 at $315^{\circ} \mathrm{C}$ (Longitudinal Direction) (From Reference. 52) 

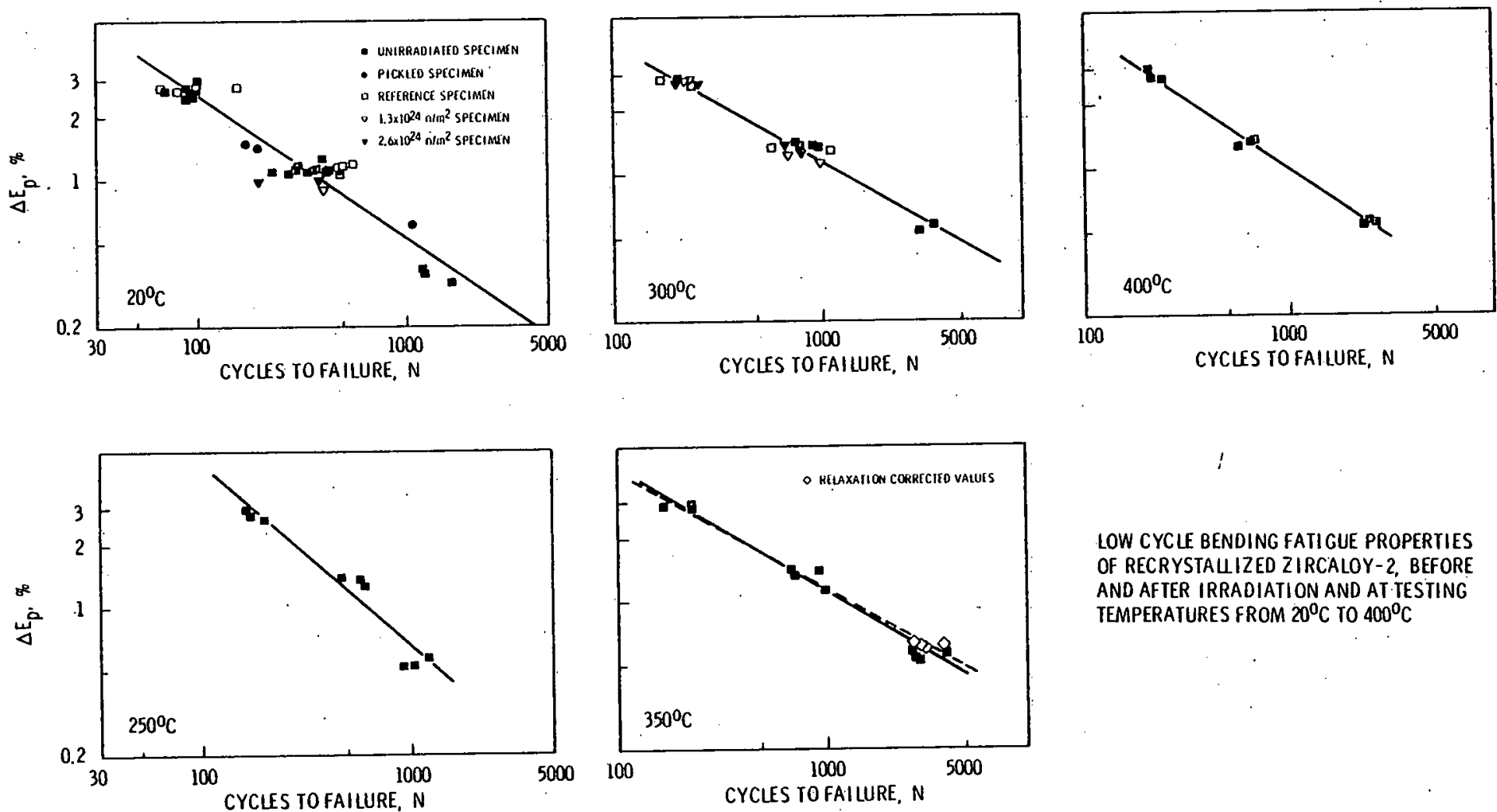

LOW CYCLF BENDING FATIGUE PROPERTIES OF RECRYSTAUIZED ZIRCALOY-2, BEFORE AND AFTER IRRADIATION AND AT TESTING TEMPERATURES FROM $20^{\circ} \mathrm{C}$ TO $400^{\circ} \mathrm{C}$

FIGURE 23. Low Cycle Bending Fatigue Properties of Recrystallized Zircaloy-2, Before and After Irradiation and at Testing Temperatures from $20^{\circ} \mathrm{C}$ to $4000 \mathrm{C}$ (From Reference 59) 


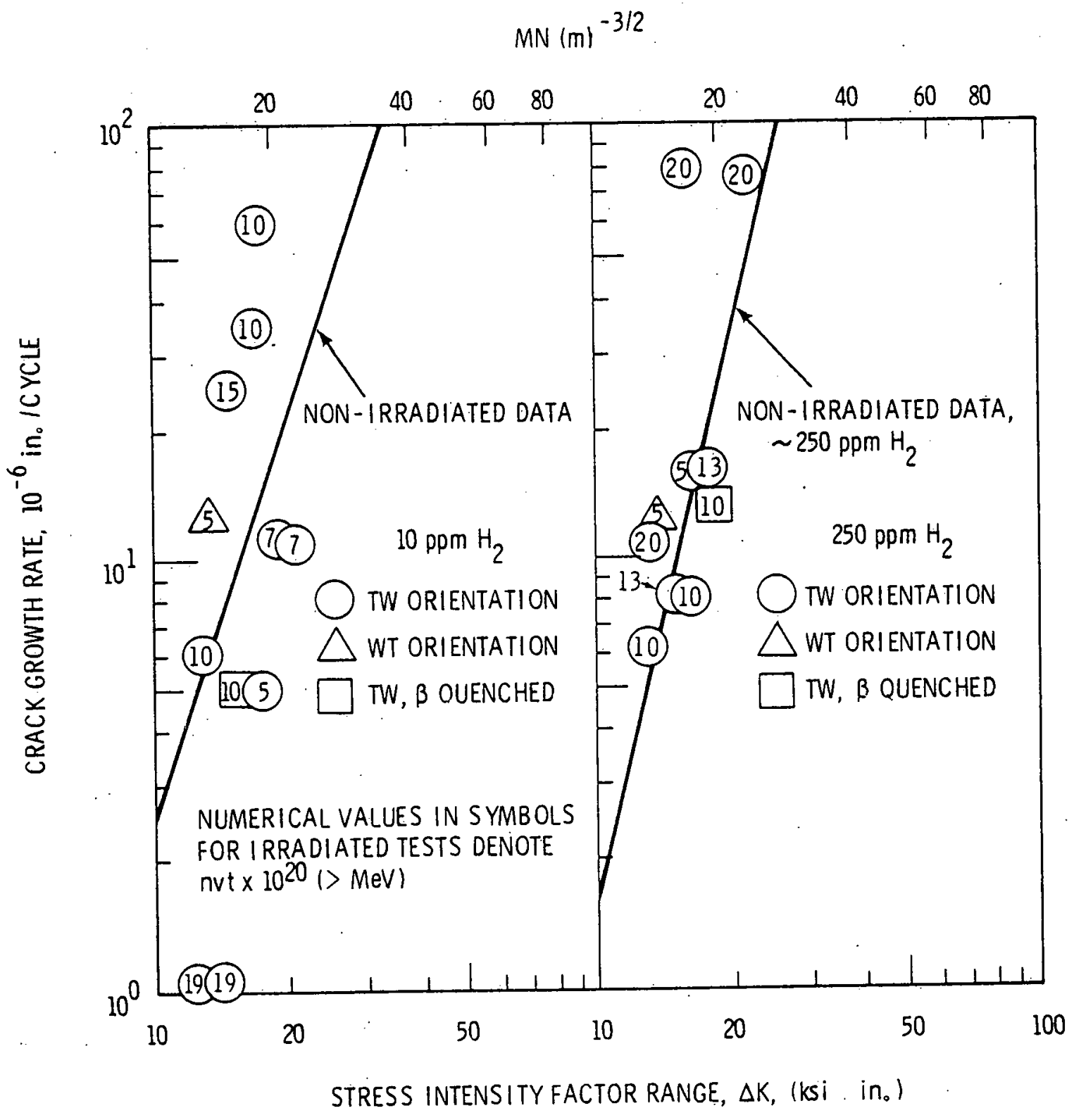

FIGURE 24. Fatigue Crack Growth Rate for Irradiated and Non-Irradiated Zircaloy-A Rolled Plate (From Reference 54) 


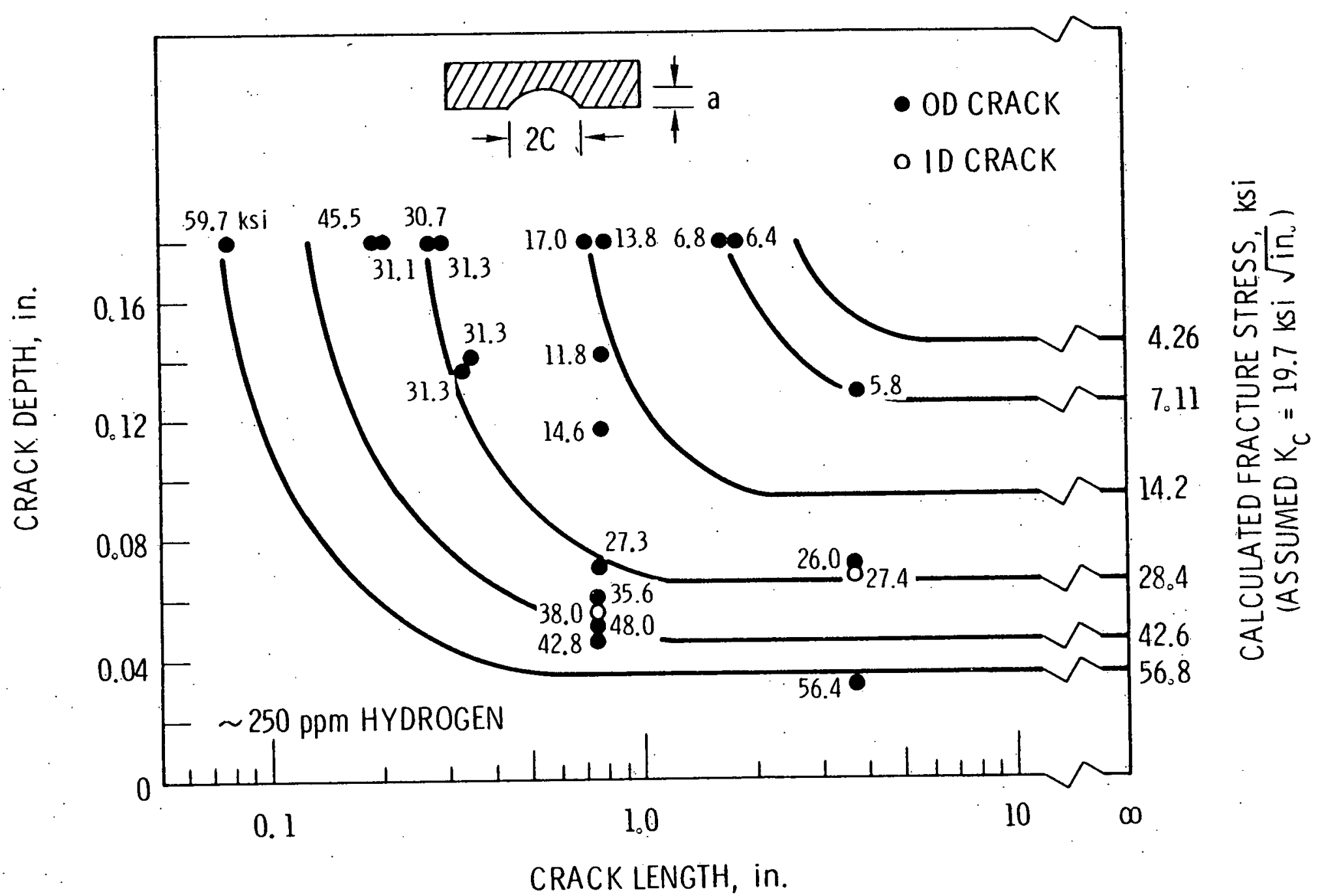

FIGURE 25. Effect of Crack Depth and Length on the Fracture Strength of Hydrided Zr-2.5 Nb Tubing at $20^{\circ} \mathrm{C}$ and Stressed by Internal Pressurization.

Numbers Adjoint to Data Points Indicate Actual Fracture Stress. Solid Curves Indicate Calculated Fracture Stress Based on an Assumed $K_{c}=19.7$ ksi in. (From Reference 55) 


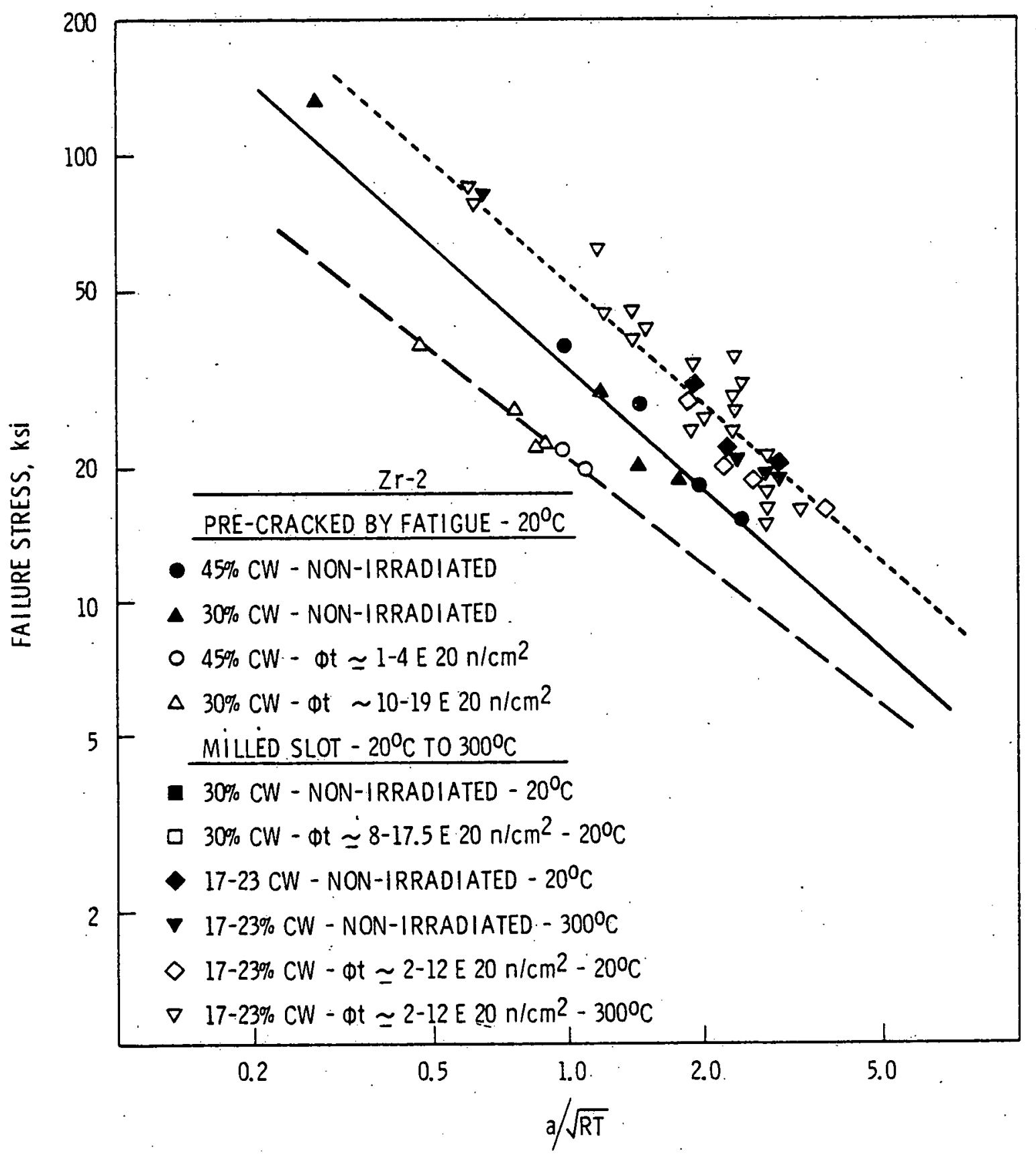

FIGURE 26: Failure Stress as a Function of the Parameter a/ $\sqrt{R T}$ for Irradiated and Nonirradiated Zircaloy-2 Tubes Defected by Machined Slits or Pre-Cracked by Fatigue (From Reference 57 through 63) 


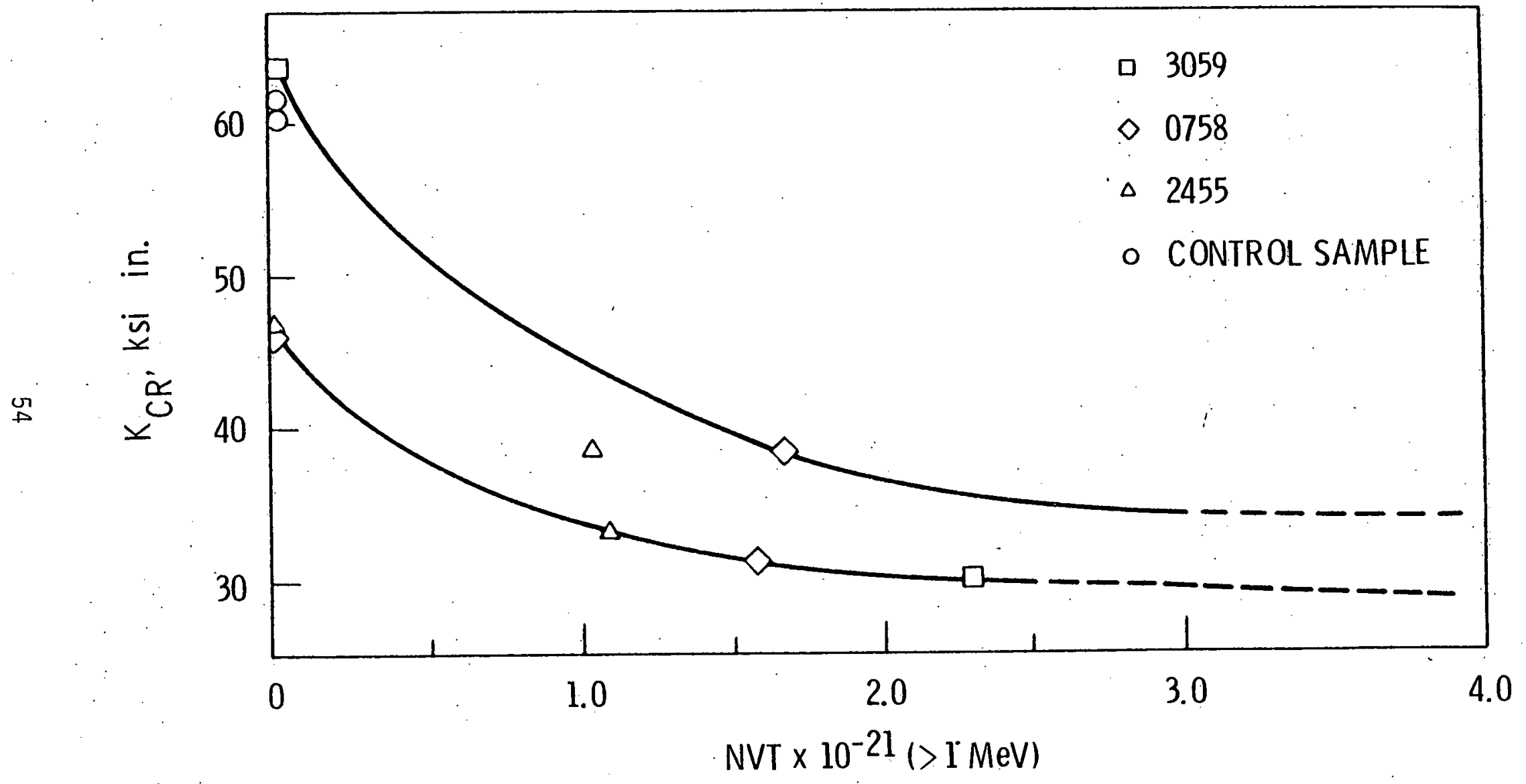

FIGURE 27. Room Temperature Fracture Toughness ( $K_{C R}$ ) as a Function of Integrated Fast Flux (From Reference 53). 


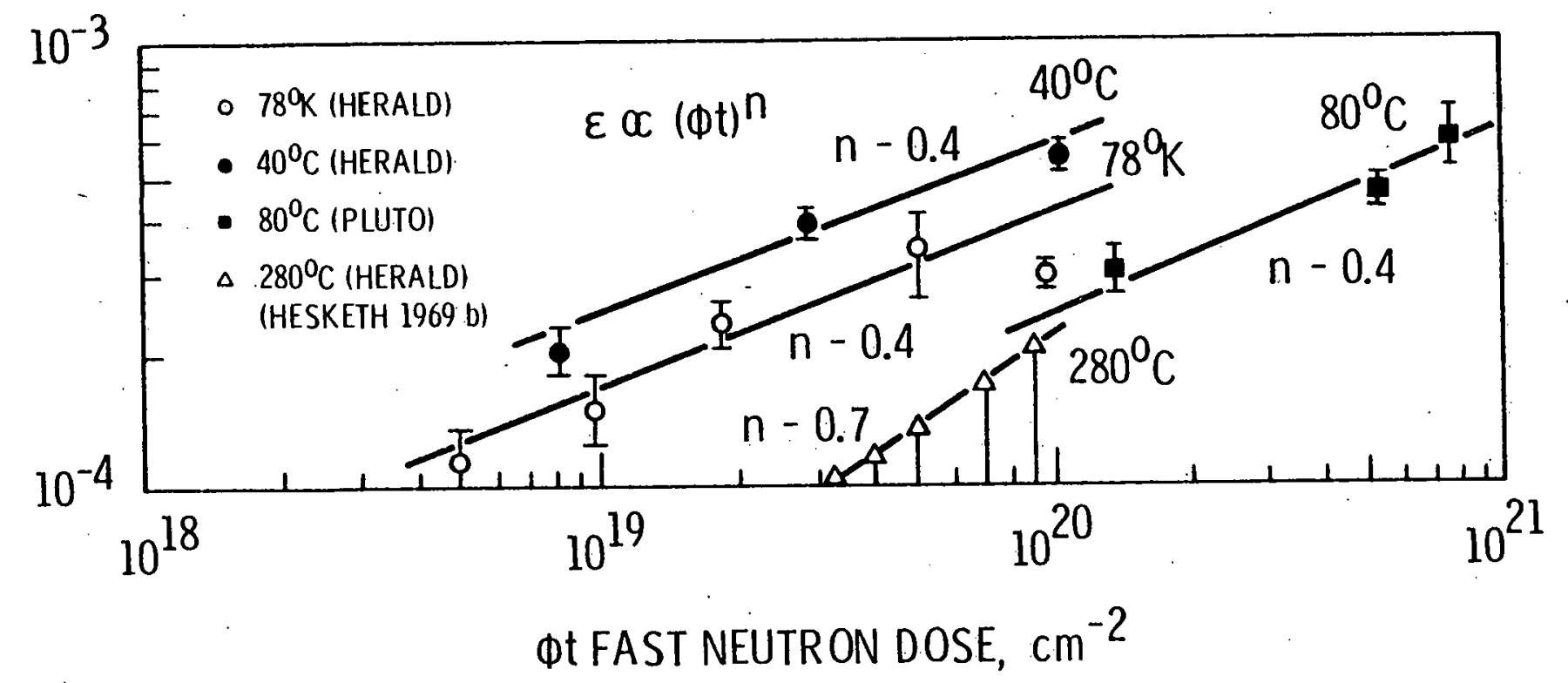

FIGURE 28. Differential Growth Strain as a Function of Dose at Four Different Irradiation Temperatures. The $280^{\circ} \mathrm{C}$ Data are Derived from Instantaneous Growth Rate Measurements 0btained by a Transducer Technique (From Reference 65) 


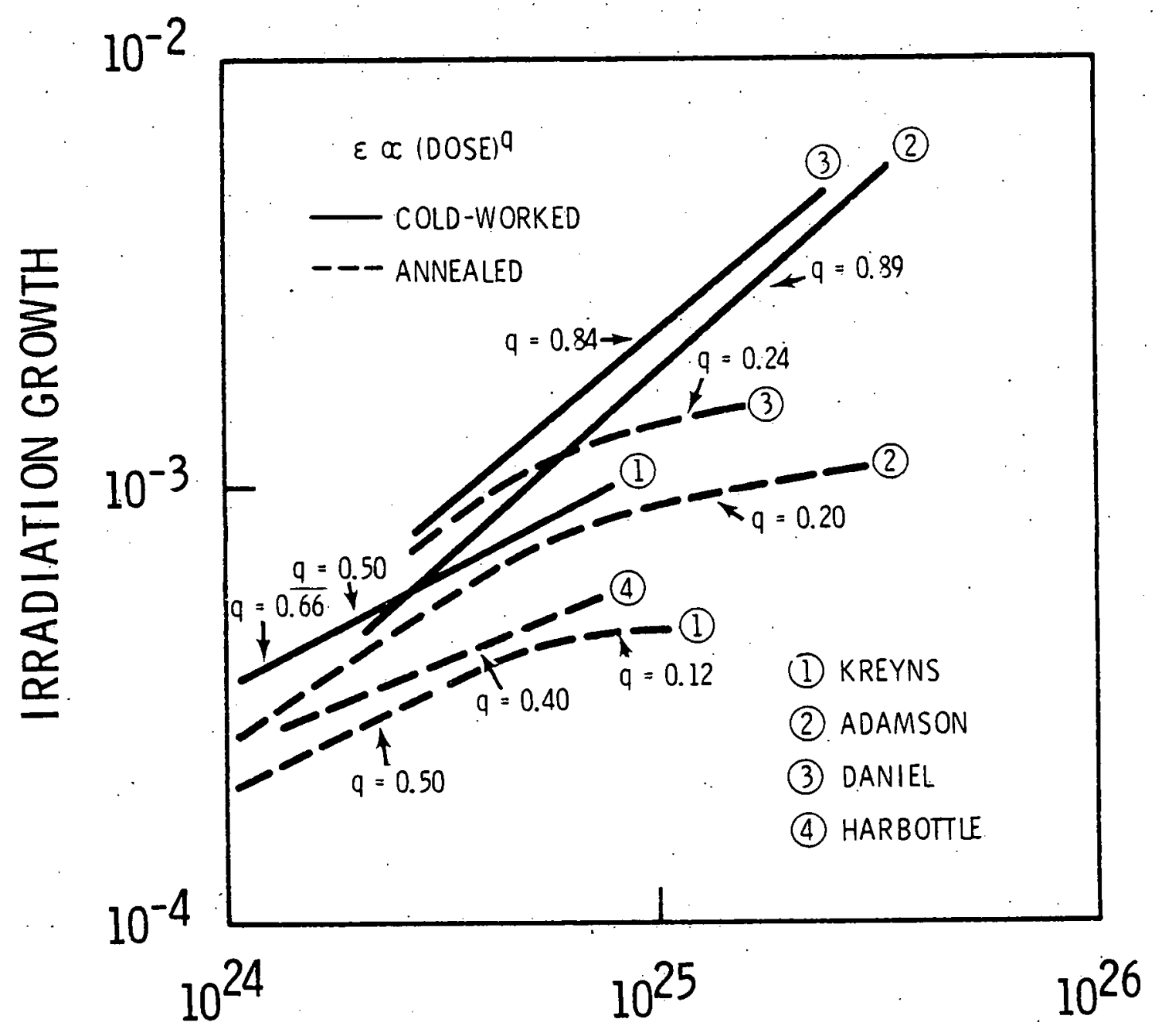

FLUENCE, $\mathrm{n} / \mathrm{cm}$

FIGURE. 29. The Fluence Dependence of Irradiation Growth of Zircaloy-2 and Zircaloy-4 at About 3000C, Except for Harbottle's Results, Which were Obtained at $800^{\circ} \mathrm{C}$ (From Reference 30) 


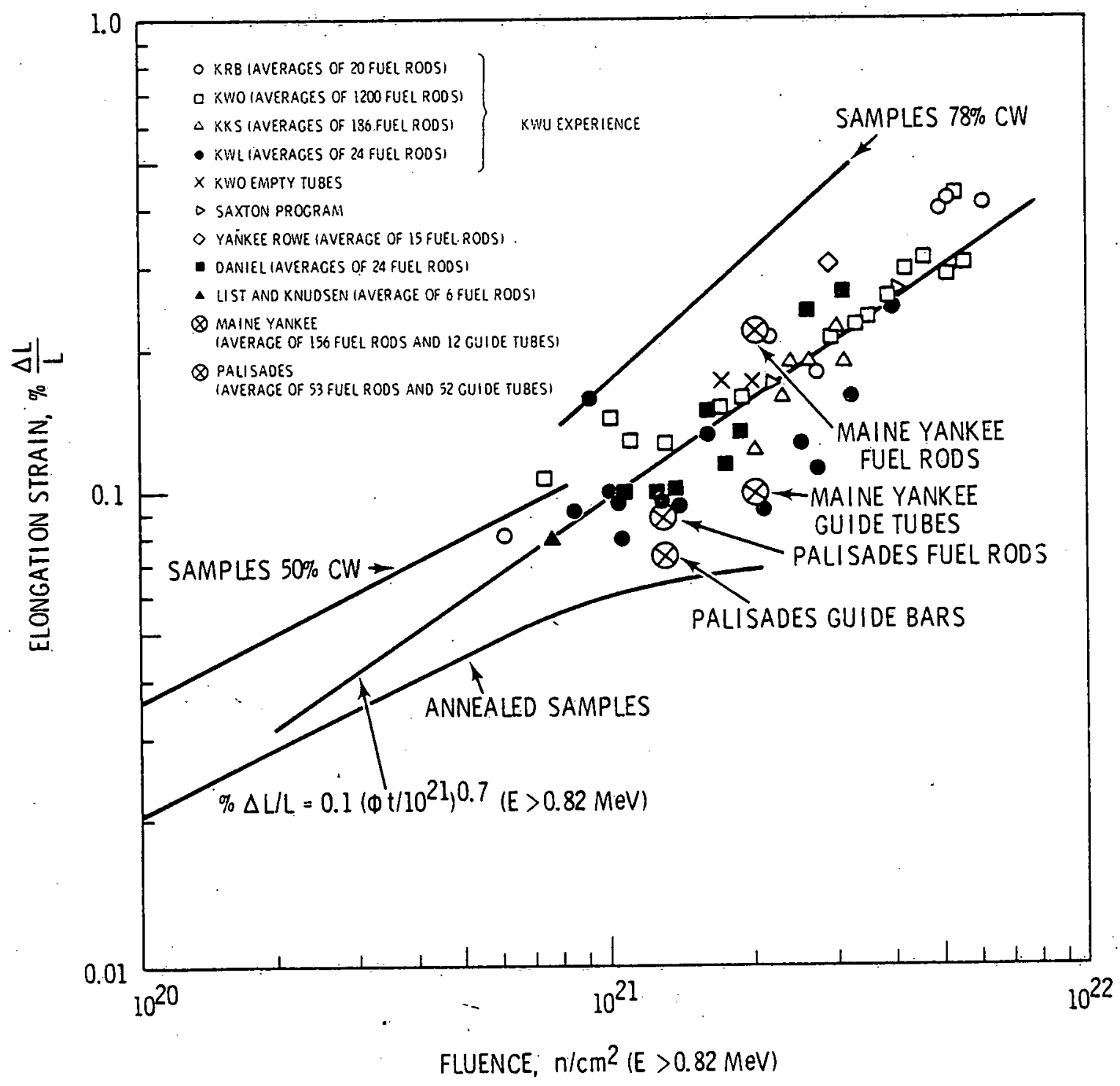

FIGURE 30. Elongation of Zircaloy-4 Fuel Clad Tubing (From Reference 68) 


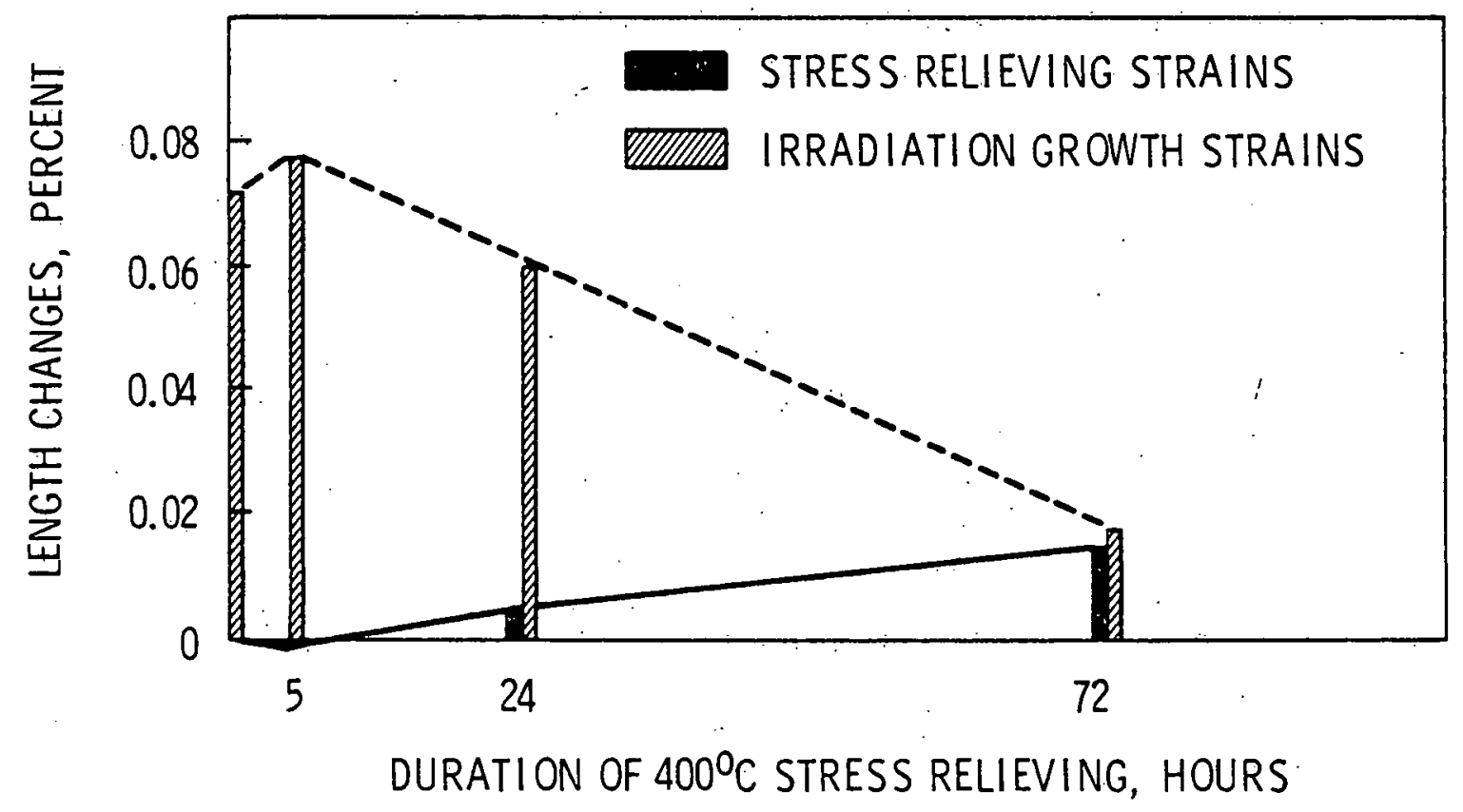

FIGURE 31. Dependence of Irradiation Growth of $40 \%$ Cold-Worked Longitudinal Slab Specimens of $\mathrm{Zr}-2.5$ wt\% $\mathrm{Nb}$ on Duration of Stress-Relieving at $400^{\circ} \mathrm{C}$. Specimens Irradiated at About $320^{\circ} \mathrm{C}$ to a total Dose of.

$2.3 \times E 20 . \mathrm{n} / \mathrm{cm}^{2}(E>1$ MeV) (From Reference 66) 
Table 1. Elastic Constants (from Ref. 8)

\begin{tabular}{|c|c|c|c|}
\hline Material & $\begin{array}{l}\text { Measuring } \\
\text { Method (a) }\end{array}$ & $\begin{array}{l}\text { Elastic Constant in psi (Top) } \\
G N / \mathrm{m}^{2} \text { (Bottom) }\left(T={ }^{\circ}\right)\end{array}$ & $\begin{array}{l}\text { Temperature Range of } \\
\text { Mea surement }-{ }^{\circ} \mathrm{C}\end{array}$ \\
\hline \multirow[t]{7}{*}{$\mathrm{Zr}-2$} & $D \& S$ & $\begin{aligned} E & =14.402 E 6-9.195 E 3(T-273) \text { in } 10^{6} \text { psi } \\
& =99.3-0.0634(T-273) \text { in } G N / m^{2}\end{aligned}$ & $20-540$ \\
\hline & $D \& S$ & Ranging between: & \\
\hline & & $\begin{aligned} E & =14.997 E 6-8.397 E 3(T-273) \\
& =103.4-0.0579(T-273)\end{aligned}$ & $20-500$ \\
\hline & & $\begin{array}{l}\text { and } \\
\begin{aligned} E & =13.793 E 6-8.397 E 3(T-273) \\
& =95.1-0.0579(T-273)\end{aligned}\end{array}$ & \\
\hline & D & $\begin{aligned} E & =14.083 E 6-8.397 E 3(T-273) \\
& =97.1-0.0579(T-273)\end{aligned}$ & $20-500$ \\
\hline & D & $\begin{aligned} G & =5.149 E 6-2.871 E 3(T-27.3) \\
& =35.5-0.0198(T-273)\end{aligned}$ & \\
\hline & D & $\begin{aligned} \nu= & \text { Decrease from } 0.367 \text { e } 20^{\circ} \mathrm{C} \\
& \text { to } 0.330 \text { a } 500^{\circ} \mathrm{C}\end{aligned}$ & \\
\hline $\mathrm{Zr}-4$ & $S$ & $\begin{aligned} \nu= & \text { Decrease from } 0.296 \text { a } 20^{\circ} \mathrm{C} \\
& \text { to } 0.243 \text { e } 400^{\circ} \mathrm{C}\end{aligned}$ & $20-400$ \\
\hline \multirow[t]{5}{*}{$\mathrm{Zr}-2.5 \mathrm{Nb}$} & D & $\begin{aligned} E & =14.112 E 6-8.702 E 3(T-273) \\
& =96.3-0.06(T-273)\end{aligned}$ & $20-500$ \\
\hline & $S$ & $\begin{aligned} E & =14.112-8.398 E 3(T-273) \\
& =96.3-0.0579(T-273)\end{aligned}$ & $20-500$ \\
\hline & D & Ranging between: & \\
\hline & & $\begin{aligned} G & =5.264 E 6-3.234 E 3(T-273) \\
& =36.3-0.0223(T-273) \\
\text { and } & =4.670 E 6-2.279 E 3(T-273) \\
& =32.2-0.0153(T-273)\end{aligned}$ & $20-500$ \\
\hline & D & $\begin{aligned} \nu= & \text { Decrease from } 0.341020^{\circ} \mathrm{C} \\
& \text { to } 0.3390500^{\circ} \mathrm{C}\end{aligned}$ & \\
\hline
\end{tabular}




\section{Table 2a. ROOM TEMPERATURE TENSILE PROPERTIES OF UNIRRADIATED AND IRRADIATED ANNEALED ZIRCALOY-2 (From Reference 14)}

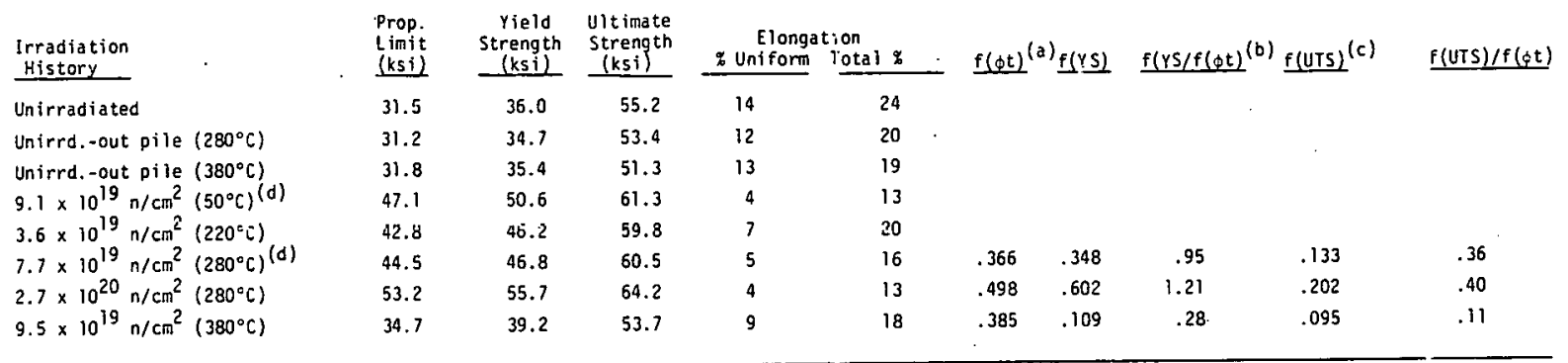

Results listed represent the average of 6 samples tested in each of the above conditions except where marked as (d); in which case result is average of 2 samples.

The $280^{\circ} \mathrm{C}$ irradiation with $2.7 \times 10^{20} \mathrm{n} / \mathrm{cm}^{2}$ was performed in the $\mathrm{X}-5$ loop; all other irradiations were performed in either low or high-cemperature fast-neutron rods.

The out-pile heat treotments were carried out for the same length of time as the corresponding irradiations at the same temperature $i . e .: 128$ days at $280^{\circ} \mathrm{C}$ and 41 ays at $380^{\circ} \mathrm{C}$.

\section{Table 2b. ROOM TEMPERATURE TENSILE PROPERTIES OF UNIRRADIATED AND IRRADIATED COLD-WORK ZIRCALOY-2 (From Reference 14)}

\begin{tabular}{|c|c|c|c|}
\hline $\begin{array}{l}\text { Irradiation } \\
\text { History } \\
\end{array}$ & $\begin{array}{l}\text { Me ta l lurgical } \\
\text { Condition } \\
\end{array}$ & $\begin{array}{l}\text { Prop. } \\
\text { Limit } \\
\text { (ksi) } \\
\end{array}$ & $\begin{array}{c}\text { Yield } \\
\text { Strength } \\
(\mathrm{ksi}) \\
\end{array}$ \\
\hline Unirradiated & $13 \%$ C.N. & 59.2 & 62.0 \\
\hline Unirrd.-out pile $\left(280^{\circ} \mathrm{C}\right)$ & $"$ & 49.5 & 52.4 \\
\hline Unirrd.-out pile $\left(380^{\circ} \mathrm{C}\right)$ & $"$ & 41.5 & 43.8 \\
\hline $3.6 \times 10^{19} \mathrm{n} / \mathrm{cm}^{2}\left(220^{\circ} \mathrm{C}\right)$ & $"$ & 60.3 & 63.6 \\
\hline $2.7 \times 10^{20} \mathrm{n} / \mathrm{cm}^{2}\left(280^{\circ} \mathrm{C}\right)$ & $"$ & 69.0 & 71.7 \\
\hline $9.5 \times 10^{19} \mathrm{n} / \mathrm{cm}^{2}\left(380^{\circ} \mathrm{C}\right)$ & $"$ & 43.4 & 47.3 \\
\hline Unirradiated & $25 \%$ C.W. and temp. ${ }^{(d)}$ & 51.1 & 54.2 \\
\hline Unirrd.-out pile $\left(280^{\circ} \mathrm{C}\right)$ & " & 49.2 & 53.4 \\
\hline Unirrd, -out pile $\left(380^{\circ} \mathrm{C}\right)$ & $"$ & 43.8 & 46.2 \\
\hline $3.6 \times 10^{19} \mathrm{n} / \mathrm{cm}^{2}\left(220^{\circ} \mathrm{C}\right)$ & $"$ & 58.9 & 62.0 \\
\hline $2.7 \times 10^{20} \mathrm{n} / \mathrm{cm}^{2}\left(280^{\circ} \mathrm{C}\right)$ & $"$ & 66.9 & 69.9 \\
\hline $9.5 \times 10^{19} \mathrm{n} / \mathrm{cm}^{2}\left(380^{\circ} \mathrm{C}\right)$ & $"$ & 44.0 & 47.6 \\
\hline
\end{tabular}

\begin{tabular}{|c|c|c|c|c|c|c|c|}
\hline $\begin{array}{c}\text { Strength } \\
\text { (ksi) } \\
\end{array}$ & $\begin{array}{r}E l \\
\text { \& Unif } \\
\end{array}$ & $\begin{array}{l}\text { ion } \\
\text { rotal } \%\end{array}$ & $\underline{f(\phi t)}$ & 1) $f(y s)$ & $f\left(\gamma s / f(\phi t)^{(0)}\right.$ & f(UTS) ${ }^{(c)}$ & $f(U T S) / f(\phi t)$ \\
\hline 65.3 & 3 & 14 & & & & & \\
\hline 59.2 & 4 & 12 & & & & & \\
\hline 54.7 & 8 & 15 & & & & & \\
\hline 68.0 & 2 & 10 & & & & & 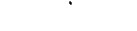 \\
\hline 73.2 & 1 & 9 & .498 & .369 & .74 & .236 & .47 \\
\hline 58.2 & 6 & 16 & .385 & .080 & .20 & .064 & .16 \\
\hline 65.0 & 6 & 16 & & & & & . \\
\hline 63.3 & 6 & 13 & & & & & \\
\hline 57.5 & 7 & 11 & & & & & \\
\hline 69.6 & 3 & 12 & & & & & \\
\hline 74.4 & 3 & 9 & .498 & . 310 & .62 & .176 & .35 \\
\hline 59.3 & 5 & 15 & .385 & .031 & .08 & .030 & .07 \\
\hline
\end{tabular}

Results 1 isted represent the average of 6 samples tested in each of the above conditions.

The out-pile heat treatmerits were carried out for the same lengths of time as the i:orresponding irradiations at the same termerature i.e.: 128 days at $280^{\circ} \mathrm{C}$ and 41 days at $380^{\circ} \mathrm{C}$.

The $280^{\circ} \mathrm{C}$ irradiation with $2.7 \times 10^{20} \mathrm{n} / \mathrm{cm}^{2}$ was performed in the $X-51000$; all othur irradiations were performed in either low or high-temparature fast-neutron rods.
(a) $\left(f(\phi t)=\sqrt[4]{1-e^{-B \phi t}}\right.$
where $B=2.35 E-22$ reciprocal fluence and $\phi t=$ fluence $(n v) n / \mathrm{cm}^{2}$
(b) $f(Y S)=\Delta Y S / Y S$
where $Y S=0.2 \%$ offset yield strength and $\Delta Y S=$ difference in yield strength for the irradiated and non-irradiated
(c) $f(U T S)=$ AUTS/UTS condition only.
where UTS = Ultimate strength and $\Delta U T S=$ difference in irradiated ultimate strength and non-irradiated ultimate strength.
(d) Tempering treatment was 15 minutes at $425^{\circ} \mathrm{C}$. 
Table 3. EFFECT OF IRRADIATION ON MECHANICAL PROPERTIES OF ZIRCALOY-2

(From Reference 16)

\begin{tabular}{|c|c|c|c|c|c|c|c|c|c|c|c|c|c|c|c|c|c|c|}
\hline \multirow{2}{*}{$\begin{array}{l}\text { MATERIAL } \\
\text { CONDITION }(A)\end{array}$} & \multirow{2}{*}{$\begin{array}{l}\text { FLUENCE, } \\
-\mathrm{N}_{\mathrm{C} \mathrm{CH}^{2}}\end{array}$} & \multirow{2}{*}{$\begin{array}{l}\text { IRR. } \\
\text { IEMP. } \\
\text { (CC) }\end{array}$} & \multirow{2}{*}{$\begin{array}{l}\text { TEST } \\
\text { TEMP. } \\
\text { (OC) }\end{array}$} & \multicolumn{2}{|c|}{$\begin{array}{l}\text { YiELD STRENGTH } \\
\text { KSI }\end{array}$} & \multicolumn{2}{|c|}{$\begin{array}{l}\text { Ultimate SIRENGTH } \\
\text { KSI }\end{array}$} & \multicolumn{4}{|c|}{$\begin{array}{l}\text { ELOMGATION, PERCENT } \\
\text { UNIFORM } \\
\text { TOTAL }\end{array}$} & \multicolumn{2}{|c|}{$\begin{array}{l}\text { REDUCTION IN } \\
\text { AREA, PERCEMT }\end{array}$} & \multirow[b]{2}{*}{$E(\phi N)^{(B)}$} & \multirow[b]{2}{*}{$E(Y S)$ (c) } & \multirow[b]{2}{*}{$E(Y S) / E(\phi r)$} & \multirow[b]{2}{*}{$E(U T S)^{(D)}$} & \multirow[b]{2}{*}{$E(U T S) / E(\phi T)$} \\
\hline & & & & UWRR. & $\mathrm{ARR}_{2}$ & UNuRR. & $\perp_{\text {RB. }}$ & UHARR. & $I_{\Omega} R_{\text {L. }}$ & $U_{\text {NIRR. }}$ & IRR. & UNARR. & LRR. & & & & & \\
\hline $\mathrm{A}-\mathrm{RD}$ & $1.1 \times 10^{20}$ & 60 & RT & 47.9 & 72.1 & 68.0 & 78.3 & 16.8 & 4.2 & 33.0 & 14.0 & 51.0 & 49.0 & J. 400 & 0.505 & 1.263 & 0.151 & 0.379 \\
\hline$A-T D$ & $1.1 \times 10^{20}$ & 60 & RT & 54.4 & 77.5 & 63.1 & 77.5 & 12.4 & 0.8 & 34.4 & 6.0 & 55.0 & & 0.400 & 0.425 & $2 . i 62$ & 0.228 & 0.570 \\
\hline $10 \mathrm{CH}-\mathrm{RD}$ & $0.84 \times 10^{19}$ & 60 & RT & 73.4 & 85.0 & 81.6 & 87.5 & 2.3 & 1.5 & 11.3 & 6.5 & 46.0 & & 0.211 & 0.158 & 0.750 & 0.072 & 0.343 \\
\hline $10 \mathrm{CH}-\mathrm{TD}$ & $0.84 \times 10^{19}$ & 60 & RT & 69.4 & 83.9 & 79.9 & $87.9^{\circ}$ & 2.7 & 1.7 & 11.6 & 4.3 & 52.0 & 50.0 & 0.211 & 0.209 & 0.990 & 0.100 & 0.475 \\
\hline $10 \mathrm{CH}-\mathrm{RD}$ & $1.1 \times 10^{20}$ & 60 & RT & 73.4 & 92.0 & 81.6 & 92.4 & 2.3 & 1.1 & 11.3 & 4.6 & 46.0 & & 0.400 & 0.253 & 0.634 & 0.132 & 0.331 \\
\hline $10 \mathrm{CH}-\mathrm{TD}$ & $1.1 \times 10^{20}$ & 60 & RT & 69.4 & 90.9 & 79.9 & 9.2 & 2.7 & 1.0 & 11.6 & 3.9 & 52.0 & 45.0 & J. 400 & 0.310 & 0.774 & 0.141 & 0.353 \\
\hline $10 \mathrm{CW}-\mathrm{RD}$ & $1.1 \times 10^{21}$ & 60 & RT & 73.4 & 91.0 & 81.6 & 91.0 & 2.3 & 0.9 & 11.3 & 5.2 & 46.0 & 41.0. & $J .691$ & 0.240 & 0.347 & 0.115 & 0.167 \\
\hline $10 \mathrm{CW}-\mathrm{TD}$ & $1.1 \times 10^{21}$ & 60 & RT & 69.4 & 92.3 & 79.9 & 92.3 & 2.7 & 01,9 & 11,6 & 4.8 & 52.0 & 19.0 & ũ. 691 & 0.330 & 0.478 & 0.155 & 0.224 \\
\hline $20 \mathrm{CH}-\mathrm{RD}$ & $0.84 \times 10^{19}$ & 60 & RT & 79.2 & 91.8 & 88.0 & 96.4 & 2.6 & 1.7 & 9.6 & 6.4 & 42.0 & & 0.211 & 0.159 & 0.754 & 0.095 & 0.452 \\
\hline $20 \mathrm{CH}-\mathrm{RD}$ & $0.84 \times 10^{19}$ & 60 & RT & 73.0 & 88.3 & 83.9 & 93.7 & 2.5 & 1.7 & 9.3 & 4.5 & 52.0 & & 0.211 & 0.209 & 0.993 & 0.117 & 0.554 \\
\hline $20 \mathrm{CH}-\mathrm{RD}$ & $1.1 \times 10^{21}$ & 60 & RT & 79.2 & 96.2 & 88.0 & 96.6 & 2.6 & 1.2 & 9.6 & $5.8^{\circ}$ & 42,0 & 40.0 & ì. 400 & U. 215 & 0.536 & 0.098 & 0.244 \\
\hline $20 \mathrm{CH}-\mathrm{TD}$ & $1.1 \times 10^{21}$ & 60 & RT & 73.0 & 98.0 & 83.9 & 98.3 & 2.5 & 1.0 & 9.3 & 3.6 & 52.0 & 45.0 & 0.400 & 34.2 & 0.856 & U.171 & 0.429 \\
\hline $20 \mathrm{CW}-\mathrm{RD}$ & $1.1 \times 10^{20}$ & 60 & RT , & 79.2 & 95.9 & 88.0 & 97.1 & 2.6 & 1.3 & 9.6 & 5.3 & 42.0 & 36.0 & 0.691 & 0.210 & 0.305 & 0.103 & 0.150 \\
\hline $20 \mathrm{CH}-\mathrm{TD}$ & $1.1 \times 10^{20}$ & 60 & RT & 73.0 & 94.4 & 83.9 & 96.1 & 2.5 & 1.2 & 9.3 & 3.2 & 52.0 & 41.0 & 0.691 & 0.293 & 0.424 & 0.145 & 0.210 \\
\hline $40 \mathrm{CH}-\mathrm{RD}$ & $0.84 \times 10^{19}$ & 60 & RT & 86.0 & 92.9 & 96.3 & 99.7 & 3.0 & 2.2 & 8.7 & 6.8 & 39.0 & 41.0 & 0.211 & 0.080 & 0.380 & 0.035 & 0.167 \\
\hline $40 \mathrm{CW}-\mathrm{TD}$ & $0.84 \times 10^{19}$ & 60 & RT & 30.3 & 92.0 & 92.4 & 98.8 & 2.5 & 2.0 & 8.3 & 4.9 & 53.0 & & 0.211 & 0.145 & 0.690 & 0.069 & 0.328 \\
\hline $40 \mathrm{CH}-\mathrm{RD}$ & $1.1 \times i 0^{20}$ & 60 & RT & 86.0 & 99.7 & 96.3 & 104.0, & 3.0 & 1.5 & 8.7 & 3.6 & 39.0 & 28.0 & 0.400 & 0.159 & 0.398 & 0.080 & 0.200 \\
\hline $40 \mathrm{CH}-\mathrm{TD}$ & $1.1 \times 10^{20}$ & 60 & RT & 80.3 & 99.6 & 92.4 & 103,0 & 2.5 & 1.5 & 8.3 & 3.0 & 53.0 & 32.0 & 0.400 & 0.240 & 0.600 & 0.115 & 0.286 \\
\hline $40 \mathrm{CH}-\mathrm{RD}$ & $1.1 \times 10^{21}$ & 60 & RT & 86.0 & 98.3 & 96.3 & 101.0 & 3.0 & 1.8 & 8.7 & 5.0 & 39.0 & 39.0 & J.691 & 0.143 & 0.207 & 0.049 & 0.071 \\
\hline $40 \mathrm{CW}-\mathrm{TD}$ & $1.1 \times 10^{21}$ & 60 & RT & 80.3 & 105.0 & 92.4 & 106.0 & 2.5 & 1.2 & 8.3 & 4.0 & 53.0 & 41.0 & 0.691 & 0.3018 & 0.445 & .147 & 0.213 \\
\hline $70 \mathrm{CW}-\mathrm{RD}$ & $0.84 \times 10^{19}$ & 60 & RT & 92.8 & 103.0 & 109.0 & 114.0 & 3.4 & 2.6 & 8.6 & 4.9 & 34.0 & & 0.211 & 0.110 & 0.521 & 0.046 & 0.217 \\
\hline $70 \mathrm{CH}-\mathrm{TD}$ & $0.84 \times 10^{19}$ & 60 & RT & 85.6 & 102.0 & 104.0 & 112.0 & 3.6 & 2.5 & 7.1 & 4.7 & 45.0 & & 0.211 & U. 191 & 0.912 & 0.076 & 0.192 \\
\hline $70 \mathrm{CH}-\mathrm{RD}$ & $1.1 \times 10^{20}$ & 60 & RT & 92.8 & 105.0 & 109.0 & 112.0 & 3.4 & 2.1 & 8.6 & 5.4 & 34.0 & 29.0 & 0.400 & 0.131 & 0.329 & 0.028 & 0.070 \\
\hline $70 \mathrm{CH}-\mathrm{TD}$ & $1.1 \times 10^{20}$ & 60 & RT & 85.6 & 108.0 & 104.5 & 116.0 & 3.6 & 1.8 & 7.1 & 2.7 & 45.0 & 21.0 & J. 400 & 0.261 & 0.654 & 0.110 & 0.275 \\
\hline $70 \mathrm{CH}-\mathrm{RD}$ & $1.1 \times 10^{21}$ & 60 & RT & 92.8 & 104.0 & 109.0 & .111 .0 & 3.4 & 3.3 & 8.6 & 6.3 & 34.0 & 30.0 & 0.691 & 0.121 & 0.175 & 0.018 & U. 027 \\
\hline $70 \mathrm{CW}$-TD & $1.1 \times 10^{21}$ & 60 & RT & 85.6 & 111.0 & .104 .0 & 114.0 & 3.6 & 1.4 & 7.1 & 3.4 & 45.0 & 23.0 & U. 691 & 0.297 & 0.429 & 0.096 & 0.139 \\
\hline
\end{tabular}

(A) Explahation of designations:

A - ANNEALED

ID - TRANSVERSE DiRECTION

RD - ROLLING DJRECTION

10 CW - 10 PERCENT COLD WORKED

A-650 - AnNeAled at $650^{\circ} \mathrm{C}$ FOR I hOUR

A-750 - ANNEALED AT $750^{\circ} \mathrm{C}$ FOR 1 HOUR

(B) $F(\phi T)=\sqrt[4]{1-E^{-B \phi T}}$ Where $B=2.35 E-22$ aECIPROCAL FLUENCE AND $\phi T=F$ LUENCE (NV) $\mathrm{N} / \mathrm{CM}^{2}$.

(c) $F(Y S)=\triangle Y S / Y S$ HHERE YS $=0.2 \%$ OFFSET YIELD STRENGTH AND $\triangle Y S=$ DIFFERENCE IN YIELD STRENGTH FOR THE IRRADIATED AND NON-IRRADIATED CONDITION ONLY.

(D) $F(U T S)=$ SUTS/UTS WHERE UTS = ULTIMATE STRENGTH AND AUTS = DIFFERENCE IN IRRADIATED ULTIMATE STRENGTH AND NCN-IRRADIATED ULTIMATE STRENGTH. 
Table 4a. TENSILE PROPERTIES OF NPR ZIRCALOY-2 TUBES

(From Reference 17)

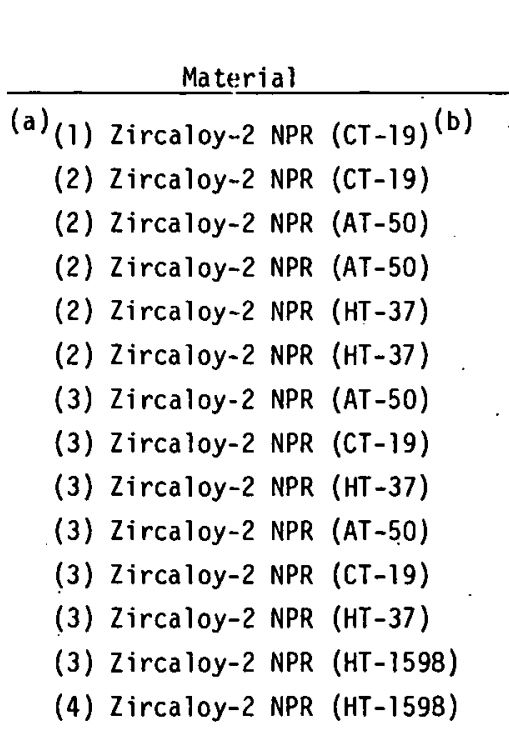

\section{Working Direction}

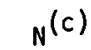

\section{$\mathrm{T}$}

N

$T$

N

$N$
$T$

$T$

$T$
$T$

$T$

$T$
$T$

$T$

$T$

$T$
$N$

(4) Zircaloy-2 NPR (HT-1598)

\section{Material} Condition As-fab. (d) As-fab. As-fab. As-fab. As-fab. As-fab. Etched (e):

\section{Etched}

Etched

Auto. (f)

Auto. (f)

Auto. (f)

Etched $(g)$
$N \cdot$ Auto. $^{(}(\mathrm{n})$

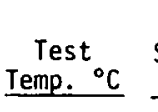

Yield, Ult timate

Strength Strength. Percent Stra in

RT
RT
RT
RT
RT
RT
RT
RT
$R T$
$R T$
$R T$
$R T$
$R T$
$R T$

57.0
60.9
70.1
67.1
61.7
63.3
66.9
55.0
64.2
66.6
56.8
63.3
81.2
57.7

.$$
\frac{k s}{79}
$$
ksi Uniform Necking(i)

(a) The number in parenthesis denotes the number of tests performed at each condition.

(b) Tube designation: $\mathrm{CT}=$ Chase Tube; $\mathrm{AT}=$ Allegheny Tube; $\mathrm{HT}=$ Harvey Tube.

(c) T and $\mathrm{N}$ refer to an orientation $90^{\circ}$ apart with respect to the minor axis of the specimen.

(d) As-fabricated specimens which had previously received a production autoclaving treatment.

(e) Same condition as (d) but with a bright chemical etch.

(f) After fabrication from an autoclaved tube, specimens were etched and reautoclaved.

$(\mathrm{g})$ These specimens were fabricated from a tube which had not been autoclaved previously.

(h) Same condition as $(g)$ but was subsequently given the production autociaving treatment.

(i) Necking strain is total strain minus uniform strain.

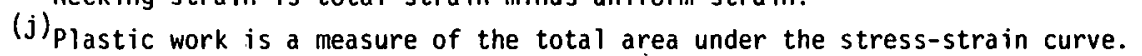




\section{Table 4b. TENSILE PROPERTIES OF NPR ZIRCALOY-2 EXPOSED IN THE OUT-OF-REACTOR LOOP (From Reference 17)}

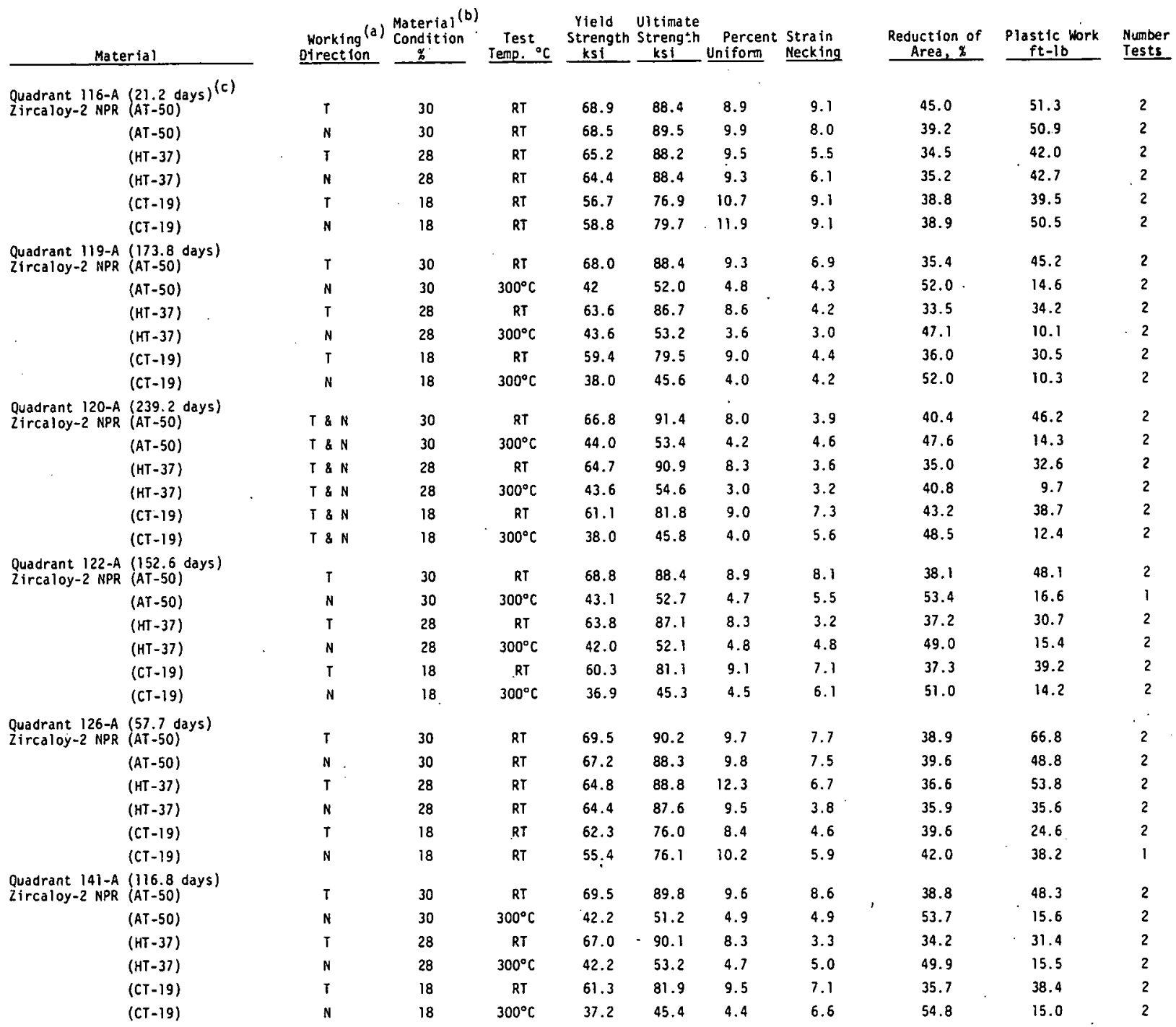

(a) Al1 specimen axes correspond to the tube axes. The designations " $F$ " and " $N$ " refer to the orientation of the width and thickness of the specimens and are 90 deg apart.

(b) The amount of cold reduction prior to any autoclaving treatments.

(c) Number of days exposed at greater than $280^{\circ} \mathrm{C}$. 
Table 4c. TENSILE PROPERTIES OF NPR ZIRCALOY-2 TUBING IRRADIATED IN THE G-7 HOT WATER LOOP, IRRADIATION TEMPERATURE - $28 \hat{c}^{\circ} \mathrm{C}$ (From Reference 17)

\begin{tabular}{|c|c|c|c|c|c|c|c|c|c|c|c|c|c|c|c|}
\hline \multirow{2}{*}{$\frac{\text { Material }}{\text { Quadrant } 116(6.9319)}$} & \multirow{2}{*}{$\frac{\substack{\text { Morking } \\
\text { Direction }}}{T}$} & \multirow{2}{*}{$\begin{array}{l}\begin{array}{l}\text { Material } \\
\text { Condition } \\
x\end{array} \\
\frac{30}{30}\end{array}$} & \multirow{2}{*}{$\frac{\underbrace{\text { Test }}_{\text {RT }}}{\text { Temp }{ }^{\circ} \mathrm{C}}$} & \multirow{2}{*}{ 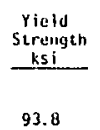 } & \multirow{2}{*}{$\frac{\begin{array}{c}\text { Ultimate } \\
\text { Strunghth } \\
\text { ksi }\end{array}}{102.4}$} & \multicolumn{2}{|c|}{$\begin{array}{r}\text { Percent Strain } \\
\text { Uniform Necking }\end{array}$} & \multirow{2}{*}{$\frac{\begin{array}{c}\text { Reduction of } \\
\text { Area, } 8\end{array}}{33.3}$} & \multirow{2}{*}{$\frac{\substack{\text { Plastic Kork } \\
\mathrm{ft}+10}}{}$} & \multirow[t]{2}{*}{$\begin{array}{l}\text { Mumber } \\
\text { lests } \\
\end{array}$} & \multirow[t]{2}{*}{$\underline{f(c)})^{(c)}$} & \multirow[t]{2}{*}{$\underline{f(Y S)^{(d)}}$} & \multirow{2}{*}{$f(Y s) / f(\& L)$} & \multirow[t]{2}{*}{$\underline{f(U T S)^{(e)}}$} & \multirow{2}{*}{$f(U T S) / f(x)$} \\
\hline & & & & & & 3.8 & 4.5 & & & & & & & & \\
\hline (AT-50) & H & 30 & RT & 94.5 & 101.8 & 3.4 & 3.5 & 33.0 & 21.6 & 3 & & & & & \\
\hline$(H T-37)$ & $\mathrm{r}$ & 28 & RT & 89.5 & 98.8 & 3.6 & 1.8 & 20.4 & 16.0 & 3 & & & & & \\
\hline (HT-37) & N & 28 & RT & 89.2 & 99.6 & 4.2 & 3.7 & 33.4 & 24.3 & 3 & & & & & \\
\hline (CT-19) & $\mathrm{T}$ & 18 & RT & 85.2 & 92.1 & 3.1 & 2.6 & 32.8 & 15.3 & 3 & & & & & \\
\hline $\begin{array}{r}\text { (CT-19) } \\
\text { (1) }\end{array}$ & n & 18 & RT & 84.3 & 93.1 & 4.0 & 4.0 & 32.9 & 22.8 & 3 & & & & & \\
\hline 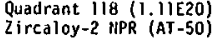 & I \& N & 30 & RT & 97.2 & 103.9 & 3.8 & 3.8 & 33.4 & 24.2 & 4 & & & & & \\
\hline (AT-50) & T\& N & 30 & $300^{\circ} \mathrm{C}$ & 59.3 & 59.3 & 0.7 & 4.0 & 40.6 & $8: 4$ & 2 & & & & & \\
\hline (HT-37) & I \& N & 28 & RT & 91.8 & 99.8 & 3.3 & 3.0 & 29.8 & 15.9 & 4 & & & & & \\
\hline$(H T-37)$ & I \& N & 28 & $300^{\circ} \mathrm{C}$ & 58.5 & 60.1 & 2.2 & 3.5 & 37.8 & 10.3 & 2 & & & & & \\
\hline (CT-19) & $T \& N$ & 18 & RT & 89.9 & 96.0 & 4.0 & 3.5 & 32.6 & 21.3 & 4 & & & & & \\
\hline (CT-19) & T \& N & 18 & $300^{\circ} \mathrm{C}$ & 53.8 & 53.9 & 0.7 & 3.6 & 43.1 & 6.6 & 2 & & & & & \\
\hline $\begin{array}{l}\text { Quadrant } 119\left(\begin{array}{l}13 \\
\text { Zircaloy-2 }\end{array} \text { NPR }\right. \\
\text { ZirT-50) }\end{array}$ & I \& N & 30 & RT & 110.8 & 116.4 & 18 & 17 & 23.0 & 10.8 & 3 & & & & & \\
\hline (AT -50$)$ & $18 \mathrm{~N}$ & 30 & $300^{\circ} \mathrm{C}$ & 72.1 & 74.0 & 1.1 & 0.8 & 31.7 & $\begin{array}{r}10.8 \\
3.5\end{array}$ & 3 & & & & & \\
\hline (HT-37) & $T \& N$ & 28 & RT & 109.0 & 115.6 & 2.6 & 1.8 & 23.8 & 14.3 & 3 & & & & & \\
\hline (HT-37) & $\mathrm{I} \& \mathrm{~N}$ & 28 & $300^{\circ} \mathrm{C}$ & $?^{3.1}$ & 78.4 & 1.2 & 1.0 & 24.5 & 4.2 & 3 & & & & & \\
\hline (CT-19) & I \& N & 18 & RT & 107.8 & 110.4 & 1.6 & 1.7 & 26.8 & 9.1 & 3 & & & & & \\
\hline (CT +19$)$ & I $8 \mathrm{~N}$ & 18 & $300^{\circ} \mathrm{C}$ & 68.4 & 72.5 & 1.0 & 1.3 & 32.5 & 4.3 & 3 & & & & & \\
\hline $\begin{array}{l}\text { Quadrant } 120(2.2521) \\
\text { Zircaloy-2 NPR (AT-50) }\end{array}$ & I $8 \mathrm{~N}$ & 30 & RT & 119.7 & 120.5 & 1.4 & 2.8 & 29.7 & 14.4 & 3 & & & & & \\
\hline (AT-50) & I \& N & 30 & $300^{\circ} \mathrm{C}$ & 75.4 & 77.8 & 1.2 & 0.8 & 32.4 & 3.5 & 3 & & & & & \\
\hline (HT-37) & I 8 N & 28 & RI & 115.6 & 116.7 & 1.7 & 1.0 & 26.1 & 8.8 & 3 & & & & & \\
\hline$(H T-37)$ & I \& N & 28 & $300^{\circ} \mathrm{C}$ & 73.0 & 76.5 & 1.3 & 0.8 & 32.1 & 3.8 & 3 & & & & & \\
\hline (CT-19) & $18 \mathrm{~N}$ & 18 & RT & 106.4 & 107.3 & 1.3 & 1.6 & 35.1 & 8.1 & 3 & & & & & \\
\hline (CT-19) & I \& N & 18 & $300^{\circ} \mathrm{C}$ & 73.9 & 75.2 & 1.0 & 0.9 & 34.6 & 3.4 & 2 & & & & & \\
\hline 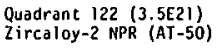 & $I \& N$ & 30 & RT & 105.8 & 107.4 & 2.3 & 2.6 & 31.6 & 15.6 & 3 & & & & & \\
\hline (AT-50) & is a & 30 & $300^{\circ} \mathrm{C}$ & & &. .0 & & $\pi .6$ & 10.0 & & & & & & \\
\hline$(H T-37)$ & $i \& N$ & 28 & RT & 103.9 & 107.7 & 2.0 & 1.2 & 28.1 & 16.6 & 3 & & & & & \\
\hline$(H T-37)$ & I \& N & 28 & $300^{\circ} \mathrm{C}$ & & & & & & & & & & & & \\
\hline (CT-19) & I \& N & 18 & RT & $10 i .3$ & 104.2 & 1.2 & 3.0 & 28.1 & 10.6 & 3 & & & & & \\
\hline (CT-19) & I \& N & 18 & $300^{\circ} \mathrm{C}$ & & & & & & & & & & & & \\
\hline $\begin{array}{l}\text { Quadrant } 124(1,63 E 20) \\
\text { Zircaloy-2 NPR } \\
\langle A T-50)\end{array}$ & $T \& N$ & 30 & RT & 101.4 & 105.4 & 3.6 & 3.3 & 32.7 & 21.9 & 3 & & & & & \\
\hline (AT-50) & I \& N & 30 & $300^{\circ} \mathrm{C}$ & 69.8 & 66.5 & 1.1 & 3.0 & 39.7 & 7.4 & 3 & & & & & \\
\hline (HT-37) & I \& N & 28 & RT & 97.5 & 105.1 & 3.3 & 2.1 & 27.2 & 16.5 & 3 & & & & & \\
\hline$(H T-37)$ & I \& N & 28 & $300^{\circ} \mathrm{C}$ & 60.0 & 62.3 & 1.7 & 2.1 & 27.7 & 6.6 & 3 & & & & & \\
\hline (CT-19) & I \& N & 18 & RT & .93 .1 & 98.4 & 3.1 & 3.3 & 31.5 & 18.0 & 3 & & & & & \\
\hline (CT-19) & I \& H & 18 & $300^{\circ} \mathrm{C}$ & 36.2 & 57.1 & 1.0 & 3.3 & 36.3 & 6.2 & 3 & & & & & \\
\hline & & & & & & & & & & & & & & & \\
\hline Zircaloy-2 NPR (AT-50) & T $8 . \mathrm{H}$ & 30 & RT & 109.4 & 113.0 & 2.4 & 2.0 & 32.0 & 18.7 & 3 & 0.594 & 0.574 & 0.967 & 0.253 & 0.426 \\
\hline (AT-50) & I \& N & 30 & $300^{\circ} \mathrm{C}$ & 67.1 & 69.2 & 1.3 & 2.1 & 40.2 & 6.2 & 3 & 0.594 & $0 . j 57$ & 0.938 & 0.313 & 0.527 \\
\hline$(H T-37)$ & $T \& N$ & 28 & $\mathrm{RT}$ & 104.6 & $111.7^{\circ}$ & 2.8 & 1.9 & 27.6 & 15.3 & 3 & 0.594 & 0.014 & 1.034 & 0.258 & 0.434 \\
\hline$(H T-37)$ & T $8 \mathrm{~N}$ & 28 & $300^{\circ} \mathrm{C}$ & 62.5 & 68.6 & 1.6 & 2.3 & 31.7 & 7.7 & 3 & 0.594 & 0.488 & 0.822 & 0.317 & 0.534 \\
\hline (CT-19) & $18 \mathrm{~N}$ & 18 & $\mathrm{RT}$ & 104.8 & 107.0 & 1.8 & 2.9 & 29.3 & 13.9 & 3 & 0.594 & 0.692 & 1.503 & 0.406 & 0.684 \\
\hline (CT-19) & 181 & 18 & $300^{\circ} \mathrm{C}$ & 63.4 & 65.3 & 1.1 & 1.7 & 34.3 & 5.0 & 3 & 0.594 & 0.718 & 1.206 & 0.442 & 0.744 \\
\hline $\begin{array}{l}\text { Quadrant } 194)(9.4925) \\
\text { Zircaloy-2 NPR } \\
(A T-50)\end{array}$ & $T s \mathrm{H}$ & 30 & RT & 113.6 & 114.4 & 2.0 & 3.1 & 28.4 & 17.1 & 3 & 0.668 & 0.634 & 0.948 & 0.274 & 0.410 \\
\hline (AT-50) & I $3 \mathrm{~N}$ & 30 & $300^{\circ} \mathrm{C}$ & & & & & & & & $\cdot \cdot$ & -- & -- & 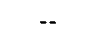 & -. \\
\hline (nT-37) & I $3 \mathrm{~N}$ & 28 & RT & 110.0 & 114.1 & 1.8 & 1.8 & 24.1 & 11.2 & 4 & 0.668 & 0.642 & 0.960 & 0.266 & 0.398 \\
\hline (HT-37) & $18 \mathrm{~N}$ & 28 & $300^{\circ} \mathrm{C}$ & & & & & & & & -. & -- & -. & -. & -. \\
\hline (CT-19) & $T \& N$ & 18 & RT & 105.9 & 109.2 & 1.4 & 2.2 & 26.3 & 10.0 & 2 & 0.668 & 0.728 & 1.089 & 0.333 & 0.498 \\
\hline (CT-19) & $T \& N$ & 18 & $300^{\circ} \mathrm{C}$ & & & & & & & & -- & -. & -- & & \\
\hline
\end{tabular}

(a) All specimen axes correspond to tube axes. The "N", refers to specimens which
have the width direction corresponding to the radial direction of the tubes.

$(d)_{f(\phi t)}=\sqrt[4]{1-e^{-\beta \phi t}}$ there $\beta=2.35 E-22$ reciprocal fluence and $\phi t=$ fluence $(n v) \mathrm{c} / \mathrm{cm}^{2}$. (b) Auluunt uf cold reduction prior to any autoclaving treatments. Where $\mathrm{rs}=0.22$ of $\mathrm{fset}$ yield strength and Ars $=$ difference in
yield strength for the irradiated and non-irradiated condition only

(c) Jutegrated exposure in nvt>1 Mev.

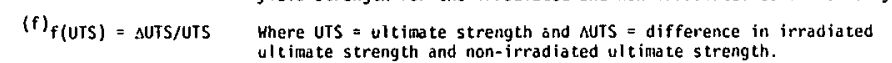


Table 4d. TENSILE PROPERTIES OF NPR ZIRACLOY-2 TUBE MATERIALS

IRRADIATED IN THE ETR G-6 CORE POSITION, IRRADIATION

TEMPERATURE (From Reference 17)

\begin{tabular}{|c|c|c|c|c|c|c|c|c|c|c|c|c|c|c|c|}
\hline Material & $\begin{array}{c}\text { Morking } \\
\text { Direction }\end{array}$ & $\begin{array}{l}\text { Material } \\
\text { Condition } \\
\\
\end{array}$ & $\begin{array}{l}\text { Test } \\
\text { Temp. }{ }^{\circ} \mathrm{C} \\
\end{array}$ & $\begin{array}{c}\text { Yield } \\
\text { Strength } \\
\text { ksi }\end{array}$ & $\begin{array}{c}\text { Ultimate } \\
\text { Strength } \\
\text { ksi }\end{array}$ & $\begin{array}{r}\text { Percent } \\
\text { Uniform }\end{array}$ & $\begin{array}{l}\text { Strain } \\
\text { recking }\end{array}$ & $\begin{array}{l}\text { Reduction of } \\
\text { Area, } 8\end{array}$ & 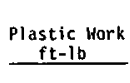 & $\begin{array}{l}\text { Number } \\
\text { Iests } \\
\end{array}$ & $f(q t)^{(c)}$ & $f(Y S)^{(d)}$ & $f(Y S) / f(\phi t)$ & $f(U I S)^{(e)}$ & $f(U T S) / f(\phi t)$ \\
\hline $\begin{array}{l}\text { Quadrant } 663(1,20 E 20)(\mathrm{C}) \\
\text { Zircaloy-2 NPR }(\text { (AT-50) }\end{array}$ & N & 30 & RT & 98.2 & 103.8 & 3.8 & 4.0 & 36.5 & 24.1 & 2 & $0: 408$ & 0.434 & 1.063 & 0.174 & 0.426 \\
\hline$\langle A T-50\}$ & N & 30 & $300^{\circ} \mathrm{C}$ & 59.8 & 61.1 & 1.3 & 2.2 & 50.1 & 6.1 & 2 & 0.408 & 0.424 & 1.038 & 0.175 & 0.428 \\
\hline 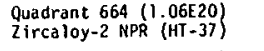 & N & 28 & RT & 90.6 & 98.4 & 4.0 & 4.2 & 29.0 & 25.3 & 2 & 0.396 & 0.394 & 0.995 & 0.118 & 0.298 \\
\hline (HT-37) & H & 28 & $300^{\circ} \mathrm{C}$ & 56.6 & 59.2 & 2.2 & 3.1 & 38.4 & 9.2 & 2 & 0.396 & 0.341 & 1.000 & 0.111 & 0.280 \\
\hline $\begin{array}{l}\text { Quadrant } 66 \text { (6. 24ET) } \\
\text { Zircal loy-2 NPR } \\
\text { (CT-19) }\end{array}$ & N & 18 & RT & 84.8 & 91.0 & 4.0 & 4.6 & 35.8 & 24.6 & $\begin{array}{l}2 \\
2\end{array}$ & $\begin{array}{l}0.347 \\
0.347\end{array}$ & $\begin{array}{l}0.467 \\
0.329\end{array}$ & $\begin{array}{l}1.344 \\
0.947\end{array}$ & $\begin{array}{l}0.162 \\
0.127\end{array}$ & $\begin{array}{l}0.466 \\
0.366\end{array}$ \\
\hline $\begin{array}{r}\text { (CT-19) } \\
\end{array}$ & $\mathrm{N}$ & 18 & $300^{\circ} \mathrm{C}$ & 50.5 & 51.4 & 1.2 & 3.4 & 46.4 & 7.2 & 2 & 0.341 & 0.329 & 0.941 & 0.127 & 0.366 \\
\hline $\begin{array}{l}\text { Quadrant } 666(9.80519) \\
\text { Zircaloy-2 NPR }(\mathrm{HT}-1598)\end{array}$ & N & 29 & RT & 94.8 & 97.9 & 2.4 & 4.0 & 37.6 & 18.9 & 2 & & & & & \\
\hline$(H T-1598)$ & N & 29 & $300^{\circ} \mathrm{C}$ & 57.0 & 58.7 & 1.0 & 2.8 & 49.8 & 6.2 & 2 & & & & & \\
\hline
\end{tabular}

(a) All specimen axes correspond to tube axes. The " $\mathrm{N}$ " refers to specimens which have the width direction corresponding to the radial direction of the tubes.

ang autaviny treatments.

(c) Integrated exposure in nvt>l Mev.

(d) $f(\phi t)=\sqrt[4]{1-e^{-\beta \phi t}} \quad$ Hhere $B=2.35 E-22$ reciprocal fluence and $\phi t=$ fluence $(\mathrm{nv}) \mathrm{n} / \mathrm{cm}^{2}$

(e) $f(Y S)=\Delta Y S / Y S$

Where $Y S=0.2 \%$ offset yield strength and $\Delta Y S=$ difference in yield strength for the irradiated and

(f) $f(U T S)=\Delta U T S / U T S$

Where UTS = ult imate strength and DUTS $=$ difference in irradiated ultimate strength and non-irradiated
ultinate strength. 
Table 5a. BATCH IDENTIFICATION AND FABRICATION DETAILS

(From Reference 19, 20)

\begin{tabular}{|c|c|c|c|c|}
\hline $\begin{array}{l}\text { Batch } \\
\text { Number }\end{array}$ & Alloy & Vendor & $\begin{array}{l}\text { Method and Amount of } \\
\text { Final Cold Reduction }\end{array}$ & $\begin{array}{l}\text { Final Stress Relief } \\
\text { Heat Treatment }\end{array}$ \\
\hline 1 & Zircaloy 2 & Z & 15 to $20 \%$ cold drawn & None \\
\hline 2 & Zircaloy 2 & Y & $15 \%$ cold drawn & None \\
\hline 7 & Zircaloy 2 & $z$ & $60 \%$ tube reduced & $2 \mathrm{~h}$ at $495^{\circ} \mathrm{C}$ \\
\hline 8 & Zircaloy 2 & $x$ & $62 \%$ tube reduced & $2 \mathrm{~h}$ at $427^{\circ} \mathrm{C}$ \\
\hline 9 & Zircaloy 2 & $x$ & $70 \%$ tube reduced & $2.5 \mathrm{~h}$ at $454^{\circ} \mathrm{C}$ \\
\hline 11 & Zircaloy 2 & v & $10 \%$ cold drawn $(a)$ & None \\
\hline 16 & Zircaloy 4 & Z & 60 to $70 \%$ tube reduced & Done, but unknown \\
\hline 17 & $\mathrm{Zr}-2.5 \mathrm{Cb}$ & $x$ & $42 \%$ tube reduced & None \\
\hline 18 & $\mathrm{Zr}-2.5 \mathrm{Cb}$ & $\gamma$ & $40 \%$ tube reduced & None \\
\hline
\end{tabular}

(a) Batch 11 was impact extruded at $800^{\circ} \mathrm{C}$ from small bar stock slugs, then reduced in two draws with an intermediate anneal to finished size. All other batches were conventionaliy extruded in the high alpha temperature range from prebored or pierced billets, followed by several cold-working and annealing operations to finished size. 
Table 5b. FABRICATION ROUTE AND TEXTURE CHARACTERISTICS OF THE TUBING BATCHES (From Reference 19, 20)

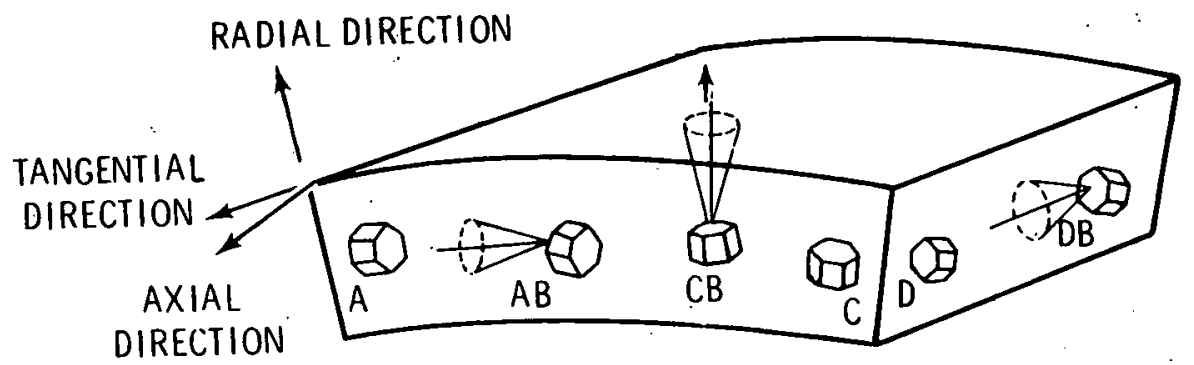

THE IDEALISED ORIENTATIONS

\begin{tabular}{|c|c|}
\hline $\begin{array}{l}\text { Batch } \\
\text { Number } \\
\text { and } \\
\text { Condition }\end{array}$ & Alloy \\
\hline $7 C$ & Zircaloy-2 \\
\hline $7 A$ & Zircaloy-2 \\
\hline $9 C$ & Zircaloy-2 \\
\hline 110 & Zircaloy -2 \\
\hline $16 C$ & Zircaloy-4 \\
\hline
\end{tabular}

\begin{tabular}{|c|c|c|}
\hline Vendor & $\begin{array}{c}\text { Method and Amount } \\
\text { of Final Cold } \\
\text { Reduction }\end{array}$ & $\begin{array}{l}\text { Final Heat } \\
\text { Treatment }\end{array}$ \\
\hline Z & $60 \%$ tube reduced & $2 \mathrm{~h}$ at $495 \mathrm{C}$ \\
\hline$Z$ & $60 \%$ tube reduced & as above plus $1 \mathrm{~h}$ at $800 \mathrm{C}$ \\
\hline$x$ & $70 \%$ tube reduced & $2.5 \mathrm{~h}$ at $.454 \mathrm{C}$ \\
\hline V & $10 \%$ cold drawn $(a)$ & none \\
\hline Z & 60 to $70 \%$ tube reduced & done, but unknown \\
\hline
\end{tabular}

\begin{tabular}{lllll}
\multicolumn{5}{c}{$\begin{array}{c}\text { <0002>Pole Texture } \\
\text { Coefficient }\end{array}$} \\
\hline A & AB & CB & C & D \\
1.1 & 1.0 & 3.7 & 5.0 & 0.1 \\
0.7 & 0.9 & 3.0 & 5.2 & 0 \\
2.6 & 1.1 & 3.0 & 4.5 & 0.2 \\
3.0 & 1.4 & 1.4 & 2.5 & 0.4 \\
3.8 & 1.1 & 2.4 & 5.6 & 0.1
\end{tabular}

(a) Batch 11 was impact-extruded at $800 \mathrm{C}(1472 \mathrm{~F})$ from small bar stock slugs, then reduced in two draws with an intermediate anneal to finished size. All other batches were conventionally extruded in the high alpha temperature range from prebored or pierced billets, followed by several cold-working and annealing operations to finished size. 
Table 5c. CLOSED END BURST TEST PROPERTIES (VALUES REPRESENT THE AVERAGE OF TWO OR THREE RESULTS) (From Reference 19, 20)

\begin{tabular}{|c|c|c|c|c|c|c|c|}
\hline \multirow{3}{*}{$\begin{array}{c}\text { Ba:ch } \\
\text { Number } \\
\text { and } \\
\text { Condition } \\
\end{array}$} & \multirow{3}{*}{$\begin{array}{c}\text { Test } \\
\text { Temperature } \\
\text { deg C } C\end{array}$} & \multicolumn{4}{|c|}{ Preirradiacion Properties } & \multirow{3}{*}{$\begin{array}{c}\text { rield } \\
\text { Strength } \\
\text { ksi }\end{array}$} & Postirradi \\
\hline & & & & & & & \\
\hline & & $\begin{array}{l}\text { Strength } \\
\text { ks } i\end{array}$ & $\begin{array}{c}\text { Strengeth } \\
k \leq i\end{array}$ & $\begin{array}{c}\text { Unifomil } \\
8\end{array}$ & $\begin{array}{c}\text { Total } \\
\mathbf{z}\end{array}$ & & $\begin{array}{l}\text { Strength } \\
\text { ksi }\end{array}$ \\
\hline & 20 & 105.5 & $\overline{107.6}$ & 2.5 & $\overline{14.3}$ & 125.7 & $\overline{125.7}$ \\
\hline $2-c$ & 20 & 91.9 & 97.7 & 4.5 & 12.8 & 122.9 & 124.0 \\
\hline $7-\mathrm{C}$ & 20 & 99.9 & 109.8 & 4.2 & 12.1 & 124.2 & 129.8 \\
\hline $8-\mathrm{C}$ & 20 & 96.5 & 101.0 & 3.2 & 12.3 & 121.7 & 121.7 \\
\hline $9-\mathrm{c}$ & 20 & 113.5 & 119.5 & 1.5 & 4.3 & 129.1 & 129.2 \\
\hline $11-\mathrm{C}$ & 20 & 82.0 & 85.0 & 4.7 & 37.5 & 108.6 & 109.0 \\
\hline $16-\mathrm{C}$ & 20 & 105.6 & 116.8 & 4.0 & 9.0 & 126.7 & 134.2 \\
\hline $17-c$ & 20 & 125.0 & 139.9 & 2.0 & 15.6 & 163.9 & 165.6 \\
\hline $18-c$ & 20 & 106.4 & 115.4 & 4.0 & 8.1 & 154.6 & 154.6 \\
\hline $1-A$ & 20 & 77.5 & 86.0 & 10.7 & 32.1 & 102.6 & 104.4 \\
\hline 7-A & 20 & 82.2 & 94.7 & 7.8 & 23.9 & 118.4 & 121.0 \\
\hline II-A & 20 & 69.0 & 80.8 & 12.8 & 27.7 & 87.6 & 88.1 \\
\hline $16-A$ & 20 & 78.0 & 88.2 & 8.7 & 37.0 & 99.1 & 106.1 \\
\hline $1-8$ & 20 & 63.7 & 74.9 & 5.0 & 14.5 & 92.1 & 93.5 \\
\hline $7-B$ & 20 & 63.8 & $75: 4$ & 5.5 & 15.8 & 93.4 & 94.2 \\
\hline $11-\mathrm{B}$ & 20 & 60.0 & 73.3 & 6.3 & 14.5 & 85.7 & 86.1 \\
\hline $16-8$ & 20 & 61.6 & 72.6 & 6.2 & 18.4 & 87.2 & 88.0 \\
\hline $1-c$ & 300 & 60.1 & 60.4 & 0.5 & 20.0 & 78.9 & 76.9 \\
\hline $2-\mathrm{C}$ & 300 & 5 to. 1 & 56.9 & 1.1 & 18.0 & 7.1 & 72.2 \\
\hline $7-\mathrm{C}$ & 300 & 59.5 & 65.2 & 2.2 & 21.5 & 85.6 & 85.8 \\
\hline $8-c$ & 300 & 57.8 & 58.4 & 1.2 & 14.8 & 71.9 & 72.6 \\
\hline g-c & 300 & 69.1 & 71.6 & 1.0 & 1.0 & 76.2 & 71.4 \\
\hline $11 . c$ & 300 & 50.8 & 51.1 & 0.7 & 53.0 & -- & 57.1 \\
\hline $16-c$ & 300 & 64.2 & 69.8 & 2.0 & 4.9 & 79.4 & 82.4 \\
\hline $17-c$ & 300 & 82.8 & 94.2 & 2.7 & 8.8 & 110.8 & 117.6 \\
\hline $18-c$ & 300 & 67.8 & 73.3 & 2.1 & 4.5 & 98.1 & 99.3 \\
\hline I-A & 300 & 28.5 & 31.2 & 12.9 & 52.9 & 55.7 & 55.7 \\
\hline $7-A$ & 300 & 28.1 & 40.8 & 8.6 & 58.8 & 64.9 & 67.6 \\
\hline $11-A$ & 300 & 26.2 & 34.0 & 13.2 & 44.9 & 46.3 & 46.7 \\
\hline $16-A$ & 300 & 26.3 & 37.8 & 11.3 & 63.5 & 59.5 & 63.2 \\
\hline $1-B$ & 300 & 27.2 & 36.1 & 6.3 & 23.4 & 53.4 & 53.5 \\
\hline $7-8$ & 300 & 27.8 & 35.8 & 6.8 & 21.4 & 53.3 & 55.4 \\
\hline $11-8$ & 300 & 26.6 & 35.4 & 10.3 & 20.2 & 51.4 & 52.9 \\
\hline $16-8$ & 300 & 26.7 & 35.9 & 7.1 & 26.3 & 48.2 & 51.5 \\
\hline
\end{tabular}

\begin{tabular}{|c|c|c|c|c|c|c|c|}
\hline \multicolumn{2}{|c|}{$\begin{array}{l}\text { Elongation } \\
\text { Uniform }\end{array}$} & \multirow{2}{*}{$\begin{array}{l}\text { Fluence } \\
\mathrm{E} 20 / \mathrm{n} / \mathrm{cm} \mathrm{m}^{2}\end{array}$} & \multirow[b]{2}{*}{$f(s, t)^{(c)}$} & \multirow[b]{2}{*}{$f(Y S)^{(d)}$} & \multirow[b]{2}{*}{$f(Y S) / f(\phi t)$} & \multirow[b]{2}{*}{$f(U T S)^{(e)}$} & \multirow[b]{2}{*}{$f(U T S) / f(\phi t)$} \\
\hline & $\begin{array}{c}\text { Total } \\
\text { Tal } \\
\end{array}$ & & & & & & \\
\hline 0.2 & 6.0 & 2.7 & 0.497 & 0.191 & 0.38 & 0.168 & 0.33 \\
\hline 0.7 & 4.0 & 2.7 & 0.497 & 0.337 & 0.67 & 0.269 & 0.54 \\
\hline 0.7 & 10.3 & 2.7 & 0.497 & 0.213 & 0.42 & 0. 182 & 0.36 \\
\hline 0 & 3.5 & 2.7 & 0.497 & 0.261 & 0.52 & 0.205 & 0.41 \\
\hline 0.3 & 1.5 & 2.7 & 0.497 & 0.137 & 0.27 & 0.081 & 0.16 \\
\hline 0.3 & 21.3 & 2.7 & 0.497 & 0.324 & 0.65 & 0.282 & 0.56 \\
\hline 0.9 & 3.1 & 2.9 & 0.506 & 0.199 & 0. $39^{\prime}$ & 0.149 & 0.29 \\
\hline 0.4 & 0.5 & 2.9 & 0.506 & 0.311 & 0.61 & 0.183 & 0.36 \\
\hline 0.2 & 1.1 & 2.9 & 0.506 & 0.453 & 0.89 & 0.339 & 0.67 \\
\hline 1.0 & 27.2 & 2.0 & 0.462 & 0.323 & 0.69 & 0.214 & 0.46 \\
\hline 0.7 & 16.4 & 2.0 & 0.462 & 0.440 & 0.95 & 0.277 & 0.60 \\
\hline 0.5 & 23.8 & 2.0 & 0.462 & 0.269 & 0.58 & 0.090 & 0.19 \\
\hline 1.1 & 23.3 & 2.0 & 0.462 & 0.270 & 0.58 & 0.202 & 0.43 \\
\hline 0.8 & 9.2 & 2.0 & 0.462 & 0.445 & 0.96 & 0.248 & 0.53 \\
\hline 0.7 & 11.3 & 2.0 & 0.462 & 0.463 & 1.00 & 0.249 & 0.53 \\
\hline 0.7 & 10.0 & 2.0 & 0.462 & 0.428 & 0.92 & 0.174 & 0.37 \\
\hline 1.0 & 12.5 & 2.0 & 0.462 & 0.415 & 0.89 & 0.212 & 0.45 \\
\hline 0.3 & 0.4 & 2.7 & 0.497 & 0.312 & 0.62 & a. 306 & 0.61 \\
\hline 0.7 & 9.8 & 2.7 & 0.497 & 0.267 & 0.53 & c. 268 & 0.54 \\
\hline 0.8 & 2.9 & 2.7 & 0.497 & 0.438 & 0.88 & G. 316 & 0.63 \\
\hline 0.7 & 0.8 & 2.7 & 0.497 & 0.243 & 0.48 & c. 243 & 0.48 \\
\hline 1.0 & 1.0 & 2.7 & 0.497 & 0.102 & 0.20 & c. 081 & 0.16 \\
\hline 0.1 & 29.0 & 2.7 & 0.497 & 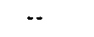 & -- & 0.124 & $0.2 n$ \\
\hline 0.7 & 2.4 & 2.9 & 0.506 & 0.236 & 0.46 & (..180 & 0.35 \\
\hline 0.4 & 1.0 & 2.9 & 0.506 & 0.338 & 0.66 & 0.298 & 0.49 \\
\hline 0.3 & 1.0 & 2.9 & 0.506 & 0.446 & 0.88 & 0.354 & 0.70 \\
\hline 0.3 & 37.6 & 2.0 & 0.462 & 0.954 & 2.06 & 0.785 & 1.69 \\
\hline 1.5 & 30.2 & 2.0 & 0.462 & 1.309 & 2.82 & 0.656 & 1.41 \\
\hline 0.3 & 32.3 & 2.0 & 0.462 & 0.767 & 1.65 & 0.373 & 0.90 \\
\hline 0.8 & 38.0 & 2.0 & 0.462 & 1.262 & 2.72 & 0.672 & 1.95 \\
\hline 0.4 & 7.7 & 2.0 & 0.462 & 0.963 & 2.08 & 0.482 & 1.04 \\
\hline 1.0 & 17.6 & 2.0 & 0.462 & 0.917 & 1.98 & 0.547 & 1.18 \\
\hline 0.1 & 17.1 & 2.0 & 0.452 & 0.932 & 2.01 & 0.494 & 1.06 \\
\hline 0.7 & 11.0 & 2.0 & 0.462 & 0.805 & 1.73 & 0.434 & 0.93 \\
\hline
\end{tabular}

(a) ihetallurgical condition code (see Tables 5a, 5b)

$A=$ alpha annealed. I $\mathrm{h}$ at $800 \mathrm{C}(1472 \mathrm{~F})$.

(b) Type of specimen code:

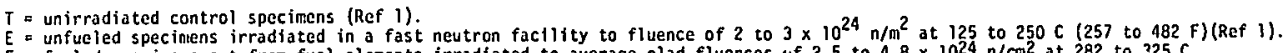

$F=$ fueled specimens cut from fuel el enents irradiated to average clad fluences of 2.5 to $4.8 \times 10^{24} \mathrm{n} / \mathrm{cm}^{2}$ at 282 to $325 \mathrm{C}$

$F+H=s$ similar to $F$ but prehydrided to $>170$ ppin hydrogen.

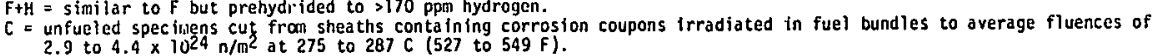

(c) $f(\phi t)=\sqrt[4]{1 \cdot e^{-\beta \phi t}}$

(d) $f(Y S)=\Delta Y S / Y S$

作

(e) $f(U T S)=\Delta U T S / U T S$ there YS $=0.22$ offsct yield strength and $\Delta Y S=$ difference in yield strength for the irradiated and

Where UTS = ultimate strength and bUTS = difference in irradiated uit timate strength and non-iradiated 
Table 5d. CLOSED END BURST TEST PROPERTIES

(From Reference 19, 20)

\begin{tabular}{|c|c|c|c|c|c|c|c|c|c|c|c|c|c|c|c|c|c|c|}
\hline \multirow{3}{*}{$\begin{array}{l}\text { Batch } \\
\text { Nunber. } \\
\text { and } \\
\text { Condition (o) }\end{array}$} & \multirow{3}{*}{$\begin{array}{l}\text { Test } \\
\text { Teuprer- } \\
\text { ature. } \\
\text { deg C } \\
\end{array}$} & \multicolumn{6}{|c|}{ Preirradialion Properties } & \multicolumn{6}{|c|}{ Postirradiation Properties } & \multirow{3}{*}{\multicolumn{2}{|c|}{$f(y s)^{(d)}$}} & \multirow[b]{3}{*}{$f(y s) / f(g t)$} & \multirow[b]{3}{*}{$\underline{f(U I S)})^{(e)}$} & \multirow[b]{3}{*}{$f(U T S) / f(\phi, t)$} \\
\hline & & \multirow{2}{*}{$\begin{array}{c}\text { rype } \\
\text { of } \\
\text { ofpechi } \\
\text { mentis) }\end{array}$} & \multirow{2}{*}{$\begin{array}{l}\text { Nunber } \\
\text { Rof of } \\
\text { Results } \\
\text { Averayled }\end{array}$} & \multirow{2}{*}{$\begin{array}{c}\text { rield } \\
\text { sirecength } \\
\text { kisi }\end{array}$} & \multirow{2}{*}{$\begin{array}{l}\text { Ultimate } \\
\text { Strength } \\
\text { ks }\end{array}$} & \multicolumn{2}{|c|}{$\begin{array}{l}\text { Elongation } \\
\text { Elogn }\end{array}$} & \multirow{2}{*}{$\begin{array}{l}\text { Type } \\
\text { of } \\
\text { Speci } \\
\text { mencen(b) }\end{array}$} & \multirow{2}{*}{$\begin{array}{c}\text { Munther } \\
\text { or } \\
\text { Results } \\
\text { Avarayed } \\
\end{array}$} & \multirow{2}{*}{$\begin{array}{c}\text { Yield } \\
\text { Strength } \\
\text { ktsi } \\
\end{array}$} & \multirow{2}{*}{ 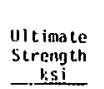 } & \multicolumn{2}{|c|}{$\begin{array}{l}\text { Flongation } \\
\text { Uniform }\end{array}$} & & & & & \\
\hline & & & & & & $\begin{array}{l}\text { Uniform } \\
\text { Percentil }\end{array}$ & $\begin{array}{l}\text { Toal } \\
\text { Percunt }\end{array}$ & & & & & $\begin{array}{l}\text { Oniform } \\
x \\
\end{array}$ & $\underline{z}$ & & & & & \\
\hline \multirow{3}{*}{$7 n$} & 22 & $T$ & 2 & $\operatorname{lix.2}$ & 94.7 & 7.8 & 23.9 & E & 2 & 118.4 & 121.0 & 0.7 & 16.4 & $0.462 / 0.510$ & 0.440 & $0.951 / 0.862$ & 0.277 & $0.600 / 0.543$ \\
\hline & & & & & & & & $\mathrm{F}$ & 5 & 138.9 & 142.8 & 0.8 & 3.2 & $0.488 / 0.571$ & 3.689 & $1.411 / 1.207$ & 0.508 & $1.039 / 0.888$ \\
\hline & . & & & - & & & & $\mathrm{F}+\mathrm{H}$ & $1^{\circ}$ & -- & 66.3 & 0 & 0 & & & & & \\
\hline \multirow[t]{3}{*}{$x$} & 22 & $\mathbf{T}$ & 3 & 99.9 & 109.8 & 4.2 & 12.1 & $\mathrm{E}$ & 3 & 124.2 & 129.8 & 0.7 & 10.3 & $0.462 / 0.510$ & 1. 242 & $0.523 / 0.474$ & 0.142 & $0.308 / 0.279$ \\
\hline & & & & & & & & $\mathbf{f}$ & 3 & 142.1 & 151.0 & 1.1 & 2.2 & $0.488 / 0.571$ & 0.422 & $0.864 / 0.739$ & 0.375 & $0.767 / 0.656$ \\
\hline & & & & & & & & $\mathrm{F}+\mathrm{H}$ & 1 & -- & 118.6 & $<0.1$ & 20.1 & & & & & \\
\hline \multirow[t]{3}{*}{96} & 22 & $\mathrm{I}$ & 1 & 113.4 & 119.5 & 1.5 & 4.3 & $\mathrm{E}$ & 2 & 129.0 & 129.2 & 0.3 & 1.5 & $0.462 / 0.510$ & 0.138 & $0.298 / 0.270$ & 0.081 & $0.175 / 0.159$ \\
\hline & & & & & & & & $\mathbf{f}$ & 2 & 130.8 & 138.8 & 0.8 & 1.0 & $0.488 / 0.571$ & 0.153 & $0.314 / 0.268$ & 0.161 & $0.330 / 0.282$ \\
\hline & & & & & & & & $F+H$ & 2 & -- & 93.3 & $<0.1$ & $<0.5$ & & & & & \\
\hline \multirow{3}{*}{ IIC } & 22 & $\mathrm{~T}$ & 3 & 81.9 & 85.0 & 4.7 & 37.5 & $\mathrm{E}$ & 3 & 108.6 & 109.0 & 0.3 & 21.3 & $0.462 / 0.510$ & 0.325 & $0.703 / 0.637$ & 0.283 & $0.612 / 0.554$ \\
\hline & & & & & & & & $\mathrm{F}$ & 2 & 114.9 & 187.9 & 0.9 & 8.4 & $0.488 / 0.571$ & 0.401 & $0.822 / 0.703$ & 0.387 & $0.792 / 0.677$ \\
\hline & & & & & & & & $\mathrm{F}+\mathrm{H}$ & 2 & $-\cdot$ & 105.9 & $<0.1$ & $<0.5$ & & & & & $\cdot$ \\
\hline \multirow[t]{3}{*}{$16 \mathrm{C}$} & 22 & T & 3 & 105.6 & 116.7 & 4.0 & 9.0 & E & 3 & 126.8 & 134.2 & 0.9 & 3.1 & $0.462 / 0.510$ & 0.200 & $0.433 / 0.392$ & 0.149 & $0.322 / 0.291$ \\
\hline & & & & & & & & $\mathrm{F}$ & 2 & 127.0 & 135.4 & 1.2 & 1.5 & $0.488 / 0.571$ & 0.203 & $0.416 / 0.355$ & 0.160 & $0.160 / 0.280$ \\
\hline & & & & & & & & $\mathrm{r}+\mathrm{H}$ & 1 & 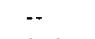 & 87.2 & $<0.1$ & $<0.5$ & & & & & \\
\hline $7 \mathrm{~A}$ & 300 & T & 3 & 28.1 & 40.8 & 8.6 & 58.8 & $E$ & 3 & 64.8 & 67.6 & 1.5 & 30.2 & $0.462 / 0.510$ & 1.306 & $2.821 / 2.555$ & 0.656 & $1.419 / 1.286$ \\
\hline & & & & & & & & $\mathbf{F}$ & 9 & 80.2 & 81.4 & 0.5 & 16.2 & $0.488 / 0.571$ & 1.854 & $3.793 / 3.244$ & 0.995 & $2.036 / 1.741$ \\
\hline & & & & & & & & $\mathrm{F}+\mathrm{H}$ & 1 & -- & 96.6 & 0.8 & 0.8 & & & & & \\
\hline $7 c$ & 300 & $\mathrm{~T}$ & 3 & 59.5 & 65.3 & 2.2 & 21.5 & $E$ & 3 & 85.6 & 85.9 & 0.8 & 2.9 & $0.462 / 0.510$ & 0.439 & $0.948 / 0.859$ & 0.315 & $0.681 / 0.617$ \\
\hline & & & & & & & & $f$ & 15 & 82.5 & 85.9 & 0.9 & 1.7 & $0.488 / 0.571$ & 0.387 & $0.793 / 0.678$ & 0.315 & $0.645 / 0.552$ \\
\hline & & & & & & & & $F+H$ & 3 & 91.8 & 95.1 & 0.6 & 0.7 & & & & & \\
\hline$x$ & 300 & $\mathrm{~T}$ & 1 & 69.0 & 71.6 & 1.0 & 1.0 & $\mathrm{E}$ & 1 & 76.1 & 77.4 & 1.0 & 1.0 & $0.462 / 0.510$ & 0.103 & $0.222 / 0.201$ & 0.081 & $0.175 / 0.159$ \\
\hline & & & & & & & & $\mathrm{F}$ & 4 & 91.2 & 95.6 & 0.7 & 0.8 & $0.488 / 0.571$ & 0.321 & $0.657 / 0.562$ & 0.334 & $0.683 / 0.584$ \\
\hline & & & & & & & & $F+H$ & 1 & 81.9 & 88.2 & 0.45 & 20.5 & & & & & \\
\hline $11 \mathrm{C}$ & 300 & T & 3 & 50.8 & 51.0 & 0.7 & 53.0 & $E$ & 3 & -- & 57.1 & 0.1 & 29.0 & $0.462 / 0.510$ & -- & $\therefore$ & 0.119 & $0.257 / 0.233$ \\
\hline & & & & & & & & $\mathrm{F}$ & 4 & 69.2 & 71.5 & 0.3 & 14.5 & $0.488 / 0.571$ & 0.363 & $0.744 / 0.637$ & 0.400 & $0.819 / 0.701$ \\
\hline & & & & & & & & $F+H$ & 3 & 69.6 & 71.4 & 0.4 & 6.6 & & & & & \\
\hline 160 & 300 & $T$ & 3 & 64.8 & 69.8 & 2.0 & 4.9 & $\mathrm{E}$ & 3 & 79.3 & 82.4 & 0.7 & 2.4 & $0.462 / 0.510$ & 0.223 & $0.483 / 0.438$ & 0.180 & $0.391 / 0.354$ \\
\hline & & & & & & & & $\mathrm{F}$ & 14 & 77.9 & 80.9 & 0.7 & 0.8 & $0.488 / 0.571$ & 0.201 & $0.412 / 0.352$ & 0.160 & $0.327 / 0.280$ \\
\hline & & & & & & & & $\mathrm{F}+\mathrm{H}$ & 3 & 85.4 & 87.4 & 0.6 & 0.9 & & & & & \\
\hline & & & & & & & & & 4 & 81.0 & 82.4 & 0.5 & 1.3 & $0.507 / 0.560$ & 0.250 & $0.493 / 0.446$ & 0.181 & $0.357 / 0.323$ \\
\hline
\end{tabular}

Metallurgical condition code (see Tables $5 a, 5$ )

$A=$ alpha annealed. I t h at $800 \mathrm{C}(1972 \mathrm{~F})$.
$\mathrm{C}=$ cold worked or cold worked and stress rel ieved.

(b) Type of specimen code:

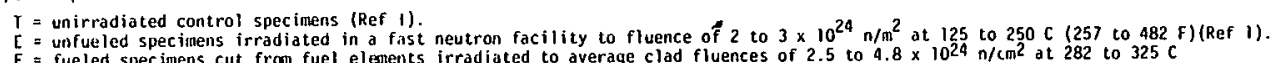

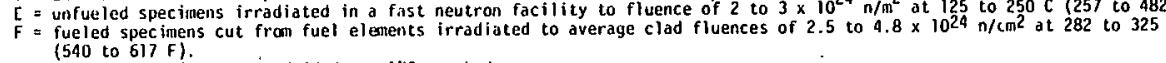

$F+11=$ sinilar to $F$ but prehydrided to $>170$ ppon hydrogen.

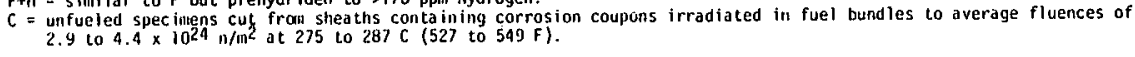

(c) $f(\psi t)=\sqrt[4]{1-e^{-\beta \beta T}}$ where $B=2.35 E-22$ reciprocal fluence and $\phi t=$ flunnce $(n v) n / \mathrm{cm}^{2}$.

(d) $f(Y S)=A Y S / Y S \quad$ Where $Y S=0 . Z Z$ of rset yield strength and ars $=$ difference in yield strength for the irradidted and

(e) $f(U T S)=$ AUTS/UIS 
Table 5e. AXIAL TUBE TENSILE PROPERTIES (VALUES REPRESENT THE AVERAGE OF TWO OR THREE RESULTS)

(From Reference 1.9, 20)

Preirradiation Properties

\begin{tabular}{|c|c|c|c|c|c|}
\hline $\begin{array}{l}\text { Batch } \\
\text { Number } \\
\text { and }\end{array}$ & $\begin{array}{c}\text { Test } \\
\text { Temperature }\end{array}$ & $\begin{array}{c}\text { Yield } \\
\text { Strength }\end{array}$ & $\begin{array}{l}\text { Ultimate } \\
\text { Strength }\end{array}$ & Elong & on \\
\hline Condition & & & & Uniform & Total \\
\hline & 20 & 83.2 & 95.9 & 5.3 & 10.5 \\
\hline $2-C$ & 20 & 76.3 & 89.7 & 4.9 & 13.3 \\
\hline $7-c$ & 20 & 79.1 & 99.9 & 7.5 & 16.5 \\
\hline $8-c$ & 20 & 83.8 & 104.3 & 5.6 & 6.3 \\
\hline $9-C$ & 20 & 88.9 & 112.7 & 6.3 & 12.1 \\
\hline $11-c$ & 20 & 59.7 & 74.8 & 8.7 & 19.4 \\
\hline $16-c$ & 20 & 80.9 & 106.0 & 8.2 & 16.7 \\
\hline $17-c^{(e)}$ & 20 & 80.5 & 108.5 & 9.3 & 22.0 \\
\hline $18-c^{(e)}$ & 20 & 79.7 & 103.0 & 9.5 & 18.5 \\
\hline 1-A & 20 & 52.3 & 77.8 & 14.8 & 23.9 \\
\hline $7-A$ & 20 & 53.9 & 72.8 & 15.4 & 25.7 \\
\hline$\| 1-A$ & 20 & 48.6 & 71.9 & 12.9 & 17.6 \\
\hline $16-\mathrm{A}$ & 20 & 49.1 & 72.0 & 17.4 & 28.3 \\
\hline $1-B$ & 20 & 57.6 & 76.5 & 10.4 & 16.5 \\
\hline $7-8$ & 20 & 57.2 & 77.7 & 12.4 & 18.3 \\
\hline $11-B$ & 20 & 54.6 & 72.4 & 10.6 & 15.8 \\
\hline $16-8$ & 20 & 54.5 & 73.7 & 9.9 & 13.8 \\
\hline $1-C$ & 300 & 48.0 & 54.2 & 2.7 & 7.0 \\
\hline $2-c$ & 300 & 43.1 & 48.7 & 2.3 & 7.4 \\
\hline $7-C$ & 300 & 51.7 & 62.3 & 4.1 & 11.8 \\
\hline $8-c$ & 300 & 50.3 & 63.3 & 4.8 & 5.4 \\
\hline $9-C$ & 300 & $61.1^{\circ}$ & 73.3 & 4.0 & 7.4 \\
\hline $11-c$ & 300 & 35.3 & 39.8 & 6.7 & 15.3 \\
\hline $16-c$ & 300 & 54.7 & 67.5 & 5.6 & 11.4 \\
\hline $17-c^{(e)}$ & 300 & 53.5 & 73.3 & 4.4 & 10.6 \\
\hline $18-c^{(e)}$ & 300 & 49.0 & 62.0 & 6.2 & 17.2 \\
\hline I-A & 300 & 18.5 & 32.7 & 15.3 & 25.3 \\
\hline $7-A$ & 300 & 18.0 & 30.3 & 22.8 & 38.2 \\
\hline II-A & 300 & 18.4 & 29.6 & $i<.0$ & 23.9 \\
\hline $16-\mathrm{A}$ & 300 & 18.6 & 32.3 & 19.3 & 32.5 \\
\hline $1-8$ & 300 & 25.0 & 37.9 & 10.2 & 16.7 \\
\hline $7-8$ & 300 & 22.5 & 38.0 & 12.2 & 18.9 \\
\hline $11-8$ & 300 & 25.5 & 35.7 & 8.9 & 13.7 \\
\hline $16-8$ & 300 & 24.4 & 35.6 & 8. 3 & 13.4 \\
\hline
\end{tabular}

Postirradiation Properties

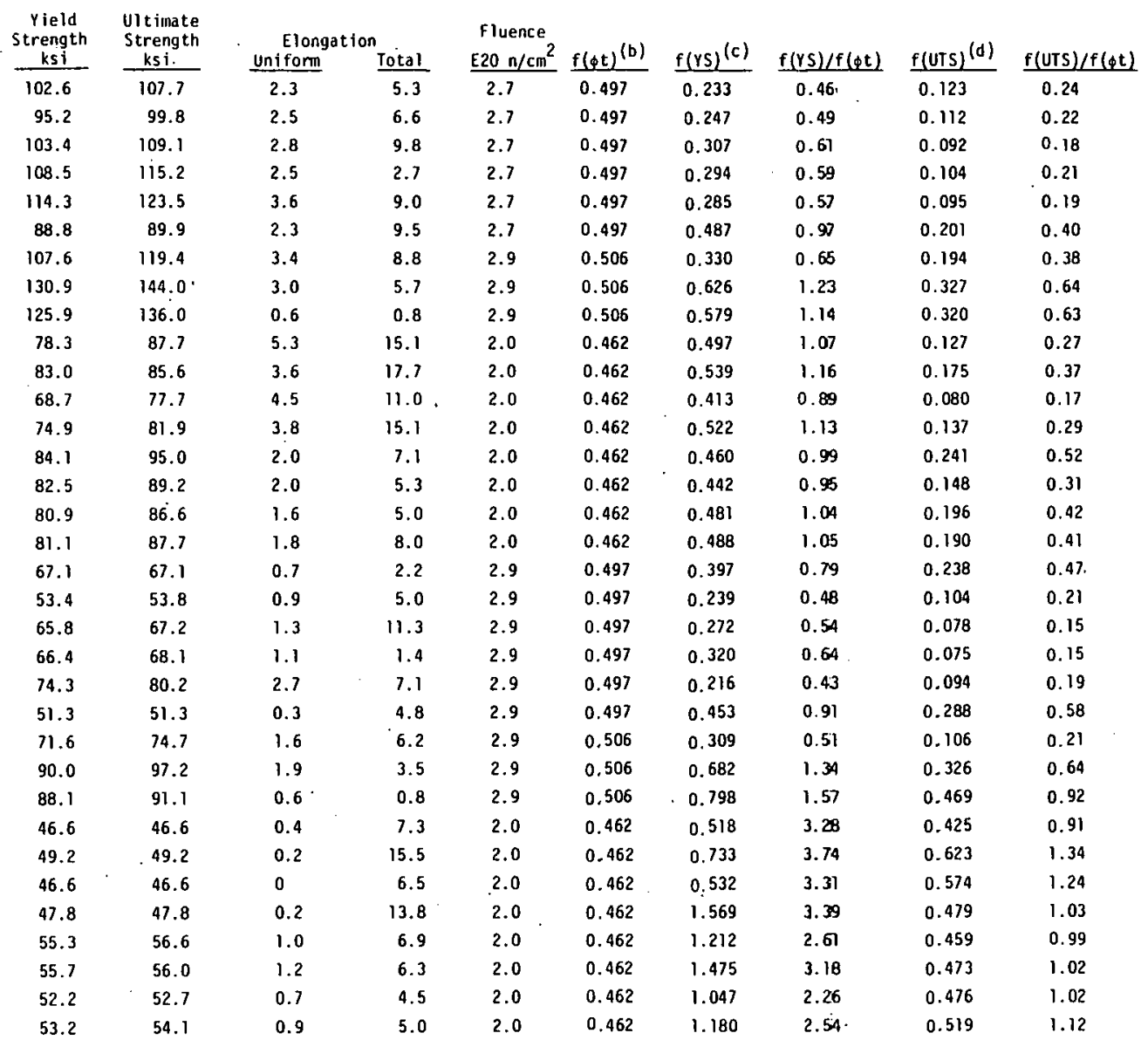

(a) Metallurgical condition code (see Tables 5a, 5b)

(b) $f(\phi t)=\sqrt[4]{-e^{-B \phi t}}$

(c) $f(Y S)=\Delta Y S / Y S$

(a) f(UTS) $=\Delta U T S / U T S$ where $\beta=2.35 E-22$ reciprocal fluence and $\phi t=$ fluerce $(n v) \mathrm{n} / \mathrm{cm}^{2}$

where $Y S=0.2 \%$ of fset yield strength and $\Delta Y S=d i f f e r e n c e$ in yield strength for the trradiated and non-irradiated condition only.

where UTS = ultimate strength and SUTS $=$ difference in irradtated ultimate strength and non-irradiated ultimate strength. 
Table 5f. RING TENSILE PROPERTIES (VALUES REPRESENT THE AVERAGE OF TWO OR FOUR RESULTS) (From Reference 19, 20)

Unirradiated Properties

Postirradiation Properties

\begin{tabular}{|c|c|c|c|c|c|c|c|c|c|c|c|c|c|c|c|}
\hline \multirow{2}{*}{$\begin{array}{c}\text { Batch } \\
\text { ilumber } \\
\text { and } \\
\text { Condition } \\
\end{array}$} & \multicolumn{5}{|c|}{ Unirradiated Properties } & \multicolumn{4}{|c|}{ Postirradiation Properties } & \multirow[b]{2}{*}{$\begin{array}{c}\text { Fluence } \\
\underline{E 20} \mathrm{n} / \mathrm{cl}^{2} \mathrm{I}^{2}\end{array}$} & \multirow[b]{2}{*}{$f(\phi t)^{(b)}$} & \multirow[b]{2}{*}{$f(y s)^{(c)}$} & \multirow[b]{2}{*}{$f(Y s) / f(\phi t)$} & \multirow{2}{*}{\multicolumn{2}{|c|}{$\underline{f(U T S)})^{(d)} \underline{f(U T S) / f(\phi t)}$}} \\
\hline & $\begin{array}{l}\text { Iest } \\
\text { Temperature, } \\
\text { deg C } \\
\end{array}$ & $\begin{array}{c}\text { Yield } \\
\text { Strength } \\
\text { ksit }\end{array}$ & $\begin{array}{l}\text { Ult inate } \\
\text { Strength } \\
\text { ksit } \\
\end{array}$ & $\begin{array}{c}\text { Elongation } \\
\text { Uniform } \\
8\end{array}$ & $\begin{array}{l}\text { Total } \\
\qquad \underline{q} \\
\end{array}$ & $\begin{array}{c}\text { Yield } \\
\text { Strength } \\
\text { ksi }\end{array}$ & $\begin{array}{l}\text { U1timate } \\
\text { Strength } \\
\text { ksi } \\
\end{array}$ & $\begin{array}{c}\text { Elongation } \\
\text { Uniform } \\
\mathrm{g}\end{array}$ & $\begin{array}{c}\text { Total } \\
x \\
\end{array}$ & & & & & & \\
\hline $1-c^{(a)}$ & 20 & 86.3 & 103.0 & 6.6 & 11.3 & $i 13.5$ & 118.5 & 3.6 & 8.1 & 2.7 & 0.497 & 0.315 & 0.633 & 0.150 & 0.302 \\
\hline $2-c$ & 20 & 72.4 & 92.2 & 9.7 & 23.5 & 106.5 & 109.0 & 3.0 & 13.9 & 2.7 & 0.497 & 0.471 & 0.946 & 0.182 & 0.365 \\
\hline $7-c$ & 20 & 78.2 & 98.0 & 9.1 & 21.9 & 112.5 & 116.5 & 3.1 & 10.5 & 2.7 & 0.497 & 0.438 & 0.880 & 0.188 & 0.379 \\
\hline $8-c$ & 20 & 88.7 & 109.2 & 8.4 & 12.2 & 111.2 & 119.5 & 4.8 & 11.9 & 2.7 & 0.497 & 0.253 & 0.509 & 0.094 & 0.189 \\
\hline $9-c$ & 20 & 89.8 & 107.5 & 6.8 & 11.4 & 118.5 & 124.3 & 3.4 & 7.7 & 2.7 & 0.497 & 0.319 & 0.641 & 0.156 & 0.313 \\
\hline $11-c$ & 20 & 60.4 & 74.2 & 9.2 & 32.9 & 86.5 & 94.6 & 4.9 & 16.8 & 2.7 & 0.497 & 0.432 & 0.867 & 0.278 & 0.552 \\
\hline $16-c$ & 20 & 96.2 & 108.3 & 3.7 & 9.6 & 130.0 & 132.0 & 0.9 & 3.0 & 2.9 & 0.506 & 0.351 & 0.694 & 0.218 & 0.432 \\
\hline $17-c$ & 20 & 90.5 & 101.9 & 3.6 & 11.0 & 136.5 & 139.0 & 0.9 & 2.8 & 2.9 & 0.506 & 0.508 & 1.00 & 0.364 & 0.719 \\
\hline $18-c$ & 20 & 84.5 & 97.1 & 3.0 & 8.8 & 101.2 & 106.9 & 1.1 & 4.5 & 2.9 & 0.506 & 0.1976 & 0.390 & 0.100 & 0.199 \\
\hline $1-A$ & 20 & 64.5 & 76.4 & 7.9 & 20.1 & 87.6 & 89.0 & 1.0 & 9.2 & 2.0 & 0.462 & 0.358 & 0.773 & 0.164 & 0.356 \\
\hline $7-A$ & 20 & 60.0 & 71.6 & 9.5 & 26.2 & 82.0 & 84.9 & 1.6 & 17.3 & 2.0 & 0.462 & 0.366 & 0.792 & 0.185 & 0.401 \\
\hline $11-A$ & 20 & 62.0 & 73.9 & 9.4 & 21.5 & 80.5 & 82.4 . & 2.0 & 11.0 & 2.0 & 0.462 & 0.298 & 0.644 & 0.115 & 0.248 \\
\hline $16-\AA$ & 20 & 59.6 & 72.1 & 9.2 & 26.4 & 83.0 & $86.0^{\circ}$ & 1.7 & 15.9 & 2.0 & 0.462 & 0.392 & 0.848 & 0.192 & 0.416 \\
\hline $1-8$ & 20 & 58.0 & 73.1 & 10.6 & 12.9 & 69.8 & 72.7 & 1.8 & 6.1 & 2.0 & 0.462 & 0.203 & 0.439 & H.M. & \\
\hline $7-8$ & 20 & 66.2 & 82.5 & 8.1 & 11.4 . & 79.0 & 83.0 & 1.9 & 6.7 & 2.0 & 0.462 & 0.193 & $0.4 ! 7$ & H.M. & \\
\hline $11-8$ & 20 & 60.2 & 75.8 & 10.7 & 13.3 & 79.7 & 84.1 & 2.4 & 6.9 & 2.0 & 0.462 & 0.323 & 0.699 & 0.109 & 0.236 \\
\hline $16-B$ & 20 & 60.9 & 76.4 & 8.8 & 12.2 & 81.8 & 86.1 & 2.1 & 6.9 & 2.0 & 0.462 & 0.343 & 0.741 & 0.127 & 0.274 \\
\hline $1-c$ & 300 & 49.4 & 53.8 & 3.7 & 13.3 & 63.4 & 66.2 & 3.0 & 10.4 & 2.7 & 0.4979 & 0.283 & 0.569 & 0.230 & 0.462 \\
\hline $2-c$ & 300 & 44.1 & 49.1 & 4.1 & 22.7 & 56.5 & 59.0 & 2.6 & 16.1 & 2.7 & 0.4979 & 0.281 & 0.564 & 0.150. & 0.302 \\
\hline $7-c$ & 300 & 50.3 & 56.6 & 4.6 & 19.0 & 67.2 & 69.5 & 2.7 & 14.9 & 2.7 & 0.4979 & 0.336 & 0.674 & 0.227 & 0.457 \\
\hline $8-c$ & 300 & 50.6 & 59.5 & 5.1 & 11.6 & 63.7 & 67.5 & 4.0 & 10.9 & 2.7 & 0.4979 & 0.258 & 0.520 & 0.134 & 0.270 \\
\hline $9-c$ & 300 & 59.3 & 68.8 & 4.9 & 10.4 & 76.2 & 81.0 & 3.2 & 9.8 & 2.7 & 0.4979 & 0.285 & 0.572 & 0.177 & 0.356 \\
\hline $11-c$ & 300 & $29.0 \%$ & 37.4 & 7.6 & 43.0 & 51.7 & 52.1 & 2.3 & 22.1 & 2.7 & 0.4979 & 0.782 & 1.572 & 0.393 & 0.789 \\
\hline $16-c$ & 300 & 53.0 & 58.3 & 1.9 & 10.0 & 60.1 & 61.2 & 0.7 & 6.4 & 2.9 & 0.5060 & 0.134 & 0.264 & 0.049 & 0.098 \\
\hline $17-c$ & 300 & 63.8 & 70.6 & 1.7 & 11.0 & 86.5 & 87.1 & 1.1 & 3.3 & 2.9 & 0.5060 & 0.355 & 0.703 & 0.233 & 0.461 \\
\hline $18-c$ & $3 n 0$ & 59.1 & 65.4 & 2.0 & 9.9 & 90.8 & 93.6 & 0.4 & 2.8 & 2.9 & 0.5060 & 0.536 & 1.060 & 0.431 & 0.852 \\
\hline I-A & 300 & 28.6 & 34.2 & 11.3 & 32.3 & 44.1 & 45.1 & 0.7 & 23.0 & 2.0 & 0.4629 & 0.542 & 1.170 & 0.318 & 0.688 \\
\hline $7-\AA$ & 300 & 24.3 & 30.5 & 12.8 & 43.2 & 40.0 & 41.1 & 0.7 & 24.5 & 2.0 & 0.4629 & 0.696 & 1.395 & 0.347 & 0.750 \\
\hline $11-A$ & 300 & 24.9 & 31.0 & 11.8 & 30.5 & 38.0 & 39.4 & 2.2 & 17.3 & 2.0 & 0.4629 & 0.526 & 1.136 & 0.277 & 0.585 \\
\hline $16-\mathrm{A}$ & 300 & 25.0 & 31.0 & 12.4 & 39.8 & 39.0 & 40.9 & 1.0 & 22.8 & 2.0 & 0.4629 & 0.560 & 1.209 & 0.319 & 0.689 \\
\hline $1-B$ & 300 & 38.8 & 39.7 & 3.5 & 10.0 & 46.8 & 47.6 & 1.2 & 5.3 & 2.0 & 0.4629 & 0.206 & 0.445 & 0.199 & 0.929 \\
\hline $7-8$ & 300 & 31.9 & 39.1 & 8.5 & 11.9 & 46.6 & 47.9 & 1.5 & 8.0 & 2.0 & 0.4629 & 0.460 & 0.995 & 0.225 & 0.986 \\
\hline $11-8$ & 300 & 31.2 & 39.4 & 9.1 & 12.7 & 43.6 & 45.2 & 1.6 & 6.8 & 2.0 & 0.4629 & 0.397 & 0.850 & 0.147 & 0.318 \\
\hline 16-B & 300 & 30.6 & 37.7 & 8.1 & 12.7 & 44.5 & 44.9 & 1.4 & 6.3 & 2.0 & 0.4629 & 0.454 & 0.981 & 0.191 & 0.412 \\
\hline
\end{tabular}

(a) Metallurgical condition code (see Tables $5 \mathrm{a}, 5 \mathrm{~b}$ )

(b) $f(\phi t)=\sqrt[4]{-e^{-B \phi t}}$

where $\beta=2.35 E-22$ reciprocal fluence and $\phi t=$ fluence $(n v) n / \mathrm{cm}^{2}$

(c) $f(Y S)=\Delta Y S / Y S$

where $Y S=0.2 \%$ of fset yield strength and $\triangle Y S=d i f$ ference in yield strength for the irradiated and

(d) $f(U T S)=\Delta U T: / U T S$ non-irradiated condition only.

where UTS = ultimate strength and AUTS = difference in irradiated ultimate strength and non-irradiated ult imate strength. 
Table 6. TENSILE TESTS ON LONGITUDINAL COUPON CLADDING SPECIMENS

(From Reference 24)

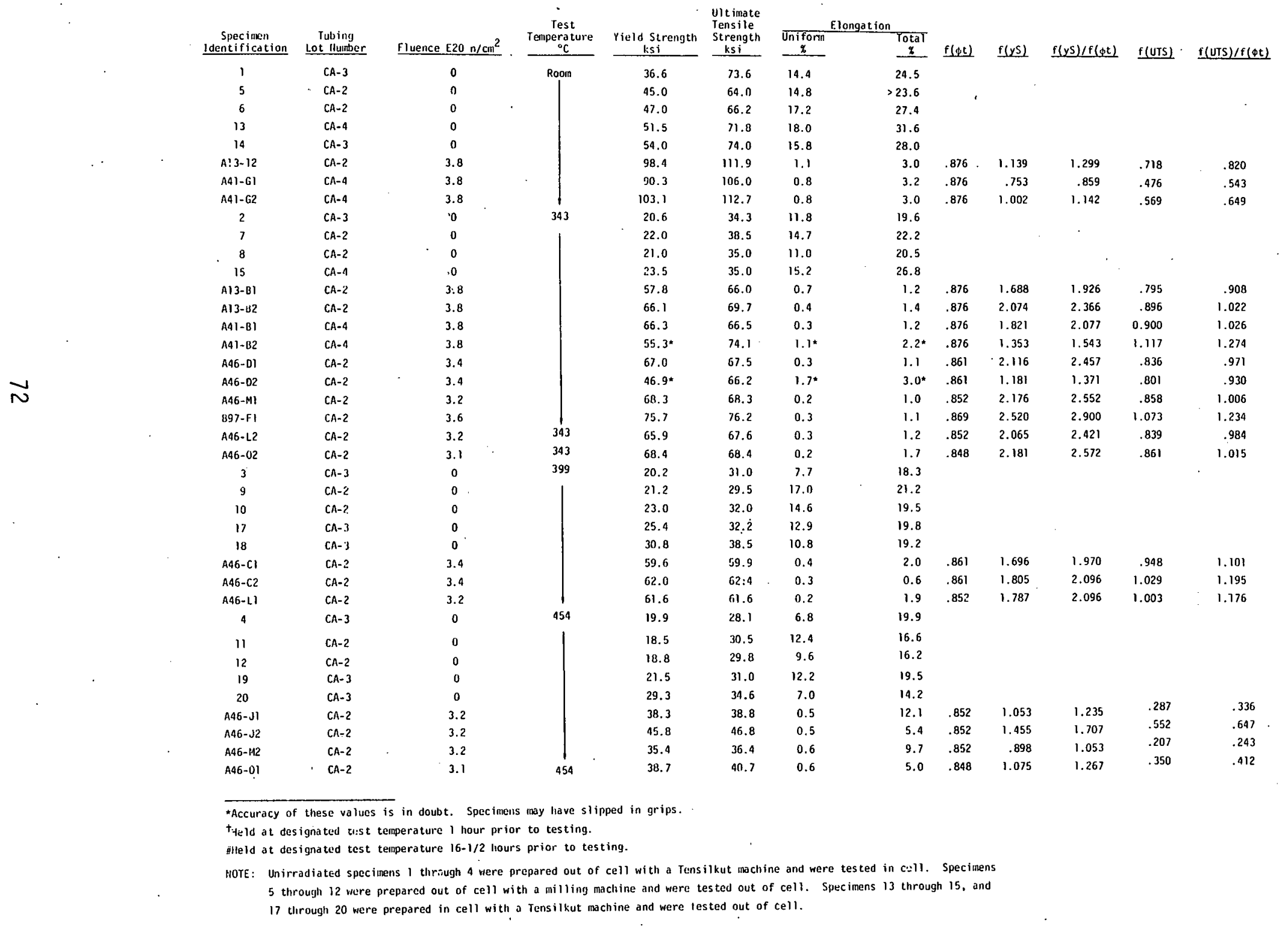


Table 7. TENSILE TEST DATA OBTAINED FROM UNIRRADIATED AND IRRADIATED ZIRCALOY-4 (GROUP A) AND ZIRCALOY-2 (GROUP B) STRIP

(From Reference 11)

\begin{tabular}{|c|c|c|}
\hline $\begin{array}{l}\text { Specimen } \\
\text { orientation } \\
\text { w.r.t. Strip } \\
\text { Rolling } \\
\text { Direction } \\
\end{array}$ & $\begin{array}{l}\text { Test } \\
\text { Temp } \\
{ }^{\circ} \mathrm{C} \\
\end{array}$ & $\begin{array}{r}\begin{array}{r}\text { Fluence } \\
\underline{E} 21 \mathrm{n} / \mathrm{cm}^{2}\end{array} \\
\end{array}$ \\
\hline \multirow{14}{*}{ A. Transverse } & 20 & .. \\
\hline & 20 & -. \\
\hline & 20 & 0.9 \\
\hline & 20 & 0.9 \\
\hline & 288 & -- \\
\hline & 288 & -. \\
\hline & 288 & -. \\
\hline & 288 & -. \\
\hline & 288 & 0.45 \\
\hline & 288 & 0.45 \\
\hline & 288 & 0.9 \\
\hline & 288 & 0.9 \\
\hline & 288 & 1.5 \\
\hline & 288 & 1.5 \\
\hline \multirow{6}{*}{$\begin{array}{l}\text { A. Longi tu- } \\
\text { dinal }\end{array}$} & 20 & .. \\
\hline & 288 & -. \\
\hline & 288 & .. \\
\hline & 288 & 0.9 \\
\hline & 288 & 0.9 \\
\hline & 288 & 1.5 \\
\hline \multirow{5}{*}{$\begin{array}{l}\text { A. Weld } \\
\text { Region }\end{array}$} & 20 & .. \\
\hline & 288 & -- \\
\hline & 288 & 0.5 \\
\hline & 288 & 0.9 \\
\hline & 288 & 1.5 \\
\hline \multirow[t]{2}{*}{ B. Transverse } & 327 & .. \\
\hline & 327 & 1.5 \\
\hline \multirow[t]{2}{*}{. } & 250 & 1.6 \\
\hline & 250 & 2.2 \\
\hline \multirow{3}{*}{$\begin{array}{l}\text { B. Transverse } \\
\text { (50 ppin oxygen) }\end{array}$} & 250 & 2.8 \\
\hline & 327 & 2.8 . \\
\hline & 327 & .. \\
\hline \multirow{3}{*}{$\begin{array}{l}\text { B. Beta- } \\
\text { guenched }\end{array}$} & 342 & -- \\
\hline & 342 & 1.0 \\
\hline & 342 & 1.0 \\
\hline
\end{tabular}

\begin{tabular}{|c|c|c|}
\hline $\begin{array}{c}\text { Yield } \\
\text { strength } \\
\text { ksi } \\
\end{array}$ & $\begin{array}{l}\text { Ult timate } \\
\text { Strength } \\
\text { ksi } \\
\end{array}$ & $\begin{array}{l}\text { Fracture } \\
\text { Strength } \\
\text { ksi } \\
\end{array}$ \\
\hline 62.6 & 71.8 & 53.8 \\
\hline 60.7 & 72.2 & 53.1 \\
\hline 115.6 & 115.6 & 86.0 \\
\hline 116.3 & 116.3 & 87.5 \\
\hline 24.3 & 30.3 & 18.6 \\
\hline 24.4 & 30.0 & 18.9 \\
\hline 24.2 & 29.9 & 18.5 \\
\hline 24.4 & 30.0 & 18.3 \\
\hline 60.0 & 72.7 & -- \\
\hline 63.4 & 74.5 & .. \\
\hline 62.6 & 76.2 & .. \\
\hline 60.9 & 75.0 & .. \\
\hline 70.2 & 77.3 & 44.8 \\
\hline 65.8 & 76.4 & 54.0 \\
\hline 52.9 & 62.6 & 47.1 \\
\hline 20.8 & 29.4 & 17.2 \\
\hline 19.8 & 29.2 & 15.6 \\
\hline 69.7 & 76.2 & 47.6 \\
\hline 63.1 & 76.6 & -. \\
\hline 60.4 & 76.8 & .- \\
\hline 70.5 & 87.3 & 74.7 \\
\hline 43.6 & 53.0 & 39.0 \\
\hline 72.9 & 87.2 & 74.2 \\
\hline 83.5 & 98.7 & 91.0 \\
\hline $85.3^{\circ}$ & 101.9 & 87.2 \\
\hline 22.5 & 28.4 & -- \\
\hline 73.8 & 75.8 & -. \\
\hline 92.0 & 82.5 & .. \\
\hline 88.6 & 89.9 & .- \\
\hline 83.6 & 84.5 & -- \\
\hline 80.3 & 81.9 & -. \\
\hline 18.6 & 25.6 & .. \\
\hline 35.0 & 41.1 & -. \\
\hline 69.1 & 72.0 & . \\
\hline & & \\
\hline
\end{tabular}

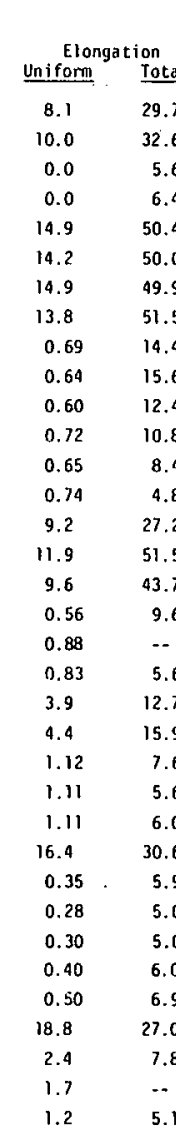

\begin{tabular}{c}
$\begin{array}{c}\text { Reduction } \\
\text { of Width } \\
\text { (Row) } \\
\text { f }\end{array}$ \\
\hline 49.7 \\
49.2 \\
19.9 \\
21.6 \\
69.0 \\
69.7 \\
69.2 \\
69.9 \\
51.8 \\
53.5 \\
49.1 \\
46.2 \\
18.3 \\
17.1 \\
46.8 \\
68.7 \\
70.1 \\
31.0 \\
7. \\
13.0 \\
20.5 \\
40.5 \\
18.7 \\
16.8 \\
13.6 \\
72.6 \\
37.1 \\
36.8 \\
32.0 \\
20.9 \\
23.6 \\
72.2 \\
25.4 \\
-2 \\
13.4 \\
\hline
\end{tabular}

\begin{tabular}{c}
$\begin{array}{c}\text { Reduction } \\
\text { of Thickness } \\
\text { (Rot) } \\
8\end{array}$ \\
\hline 14.1 \\
13.7 \\
10.2 \\
10.7 \\
26.8 \\
24.4
\end{tabular}

Row $\begin{gathered}\text { Reduction } \\ \text { of Area } \\ \text { Rot }\end{gathered}$

$f(p+)^{(a)}$ $3.52 \quad 56.8$

60.6

$\begin{array}{lll}1.95 & 28.1 & .661 \\ 2.02 & 30.0 & 0\end{array}$

$\begin{array}{ll}2.02 & 30.0 \\ 2.57 & 77.3\end{array}$

$\begin{array}{lllll}.661 & .888 & 1.344 & .605 & .915\end{array}$

24.4

$2.86 \quad 77.1$

$\begin{array}{lll}24.9 & 2.84 & 76.7 \\ 14.1 & 2.81 & 77.3\end{array}$

$\begin{array}{llll}14.1 & 3.67 & 66.1 & .563\end{array}$

$\begin{array}{rlr}14.1 & 3.79 & 60.1 \\ 9.3 & 5.3 & 55.9\end{array}$

$\begin{array}{lll}9.3 & 5.3 & 60 . \\ 16.1 & 2.87\end{array}$

10.7

16.6

$\begin{array}{ll}16.1 & 2.91\end{array}$

$25.9-2.65 \quad 76.8$

$\begin{array}{lll}29.3 & 2.39 & 78.8\end{array}$

$\begin{array}{lll}15.6 & 1.99 & 41.7\end{array}$

$\begin{array}{lll}15.6 & -- & 41.7 \\ 15.6 & 0.83 & 26.6\end{array}$

$27.5-0.75 \quad 26.6$

41.2

$19.4 \quad 0.96$

$\begin{array}{ll}19.4 & 0.96 \\ 21.3 & 0.79\end{array}$

$\begin{array}{llll}4.2 & 0.96 & 34.5 & .69 \\ 14.9 & .738\end{array}$

$7.3 \quad 5.1$

7.5

10.0

8.4

13.9

37.3

(a) $f(\phi t)=\sqrt[4]{1-e^{-B \phi t}}$

(b) $f(Y S)=\Delta Y S / Y S$

Where $\beta=2.35 E-22$ reciprocal fluence and $\phi t=$ fluence $(\mathrm{nv}) \mathrm{n} / \mathrm{cm}^{2}$.

(c) $f(U T S)=\Delta U T S / U T S$

\section{non-irradiated condition only.}

Where UTS $=$ ultinate strength and DUTS $=$ difference in irradiated ultimate strength and non-irradiated

ultimate strength. 
Table 8. TENSILE TEST DATA OF IRRADIATED AND UNIRRADIATED ZIRCONIUM ALLOY SPECIMENS TESTED AT $250^{\circ} \mathrm{C}$ TO DETERMINE THE EFFECT OF TEXTURE OF STRENGTH AND DUCTILITY (STRAIN RATE 0.05/MIN) (From Reference 12)

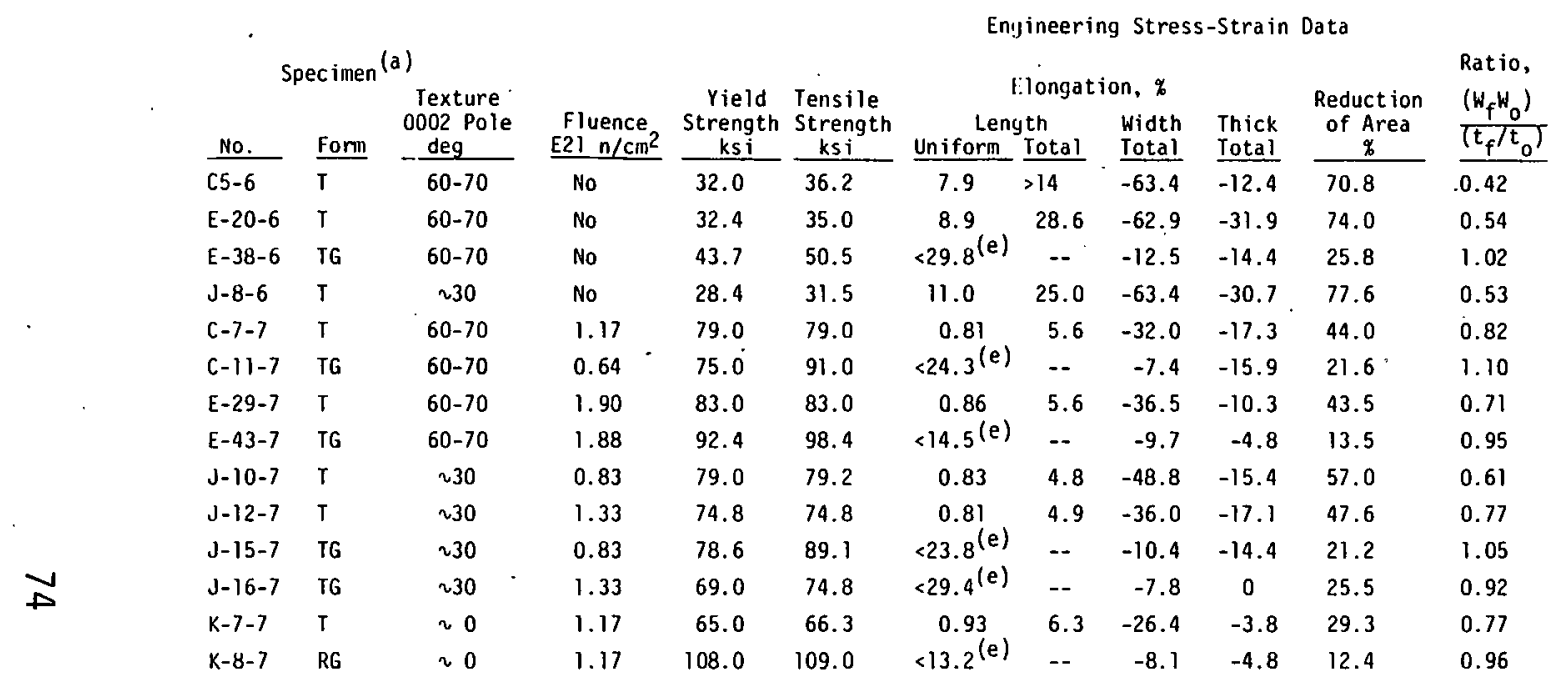

$\begin{array}{ccccc}\frac{f(\phi c)^{(b)}}{--} & \frac{f(Y S)^{(c)}}{--} & \frac{f(Y S) / f(\phi t)}{--} & \frac{f(U T S)^{(d)}}{--} & \frac{f(U T S) / f(\phi t)}{--} \\ -. & -. & -- & -- & -- \\ -- & -- & -- & -- & -- \\ -- & -- & -- & -- & -- \\ .700 & 1.453 & 2.075 & 1.219 & 1.741 \\ .611 & 0.716 & 1.171 & 0.802 & 1.312 \\ .774 & 1.577 & 2.036 & 1.331 & 1.718 \\ .773 & 1.114 & 1.441 & 0.948 & 1.227 \\ .648 & 1.782 & 2.746 & 1.514 & 2.334 \\ .720 & 1.633 & 2.269 & 1.374 & 1.909 \\ .648 & 1.767 & 2.724 & 1.828 & 2.818 \\ .720 & 1.429 & 1.986 & 1.374 & 1.909 \\ -- & -- & -- & -- & -- \\ -- & -- & -- & -- & --\end{array}$

(a) Specinen form; $T$ = tensile specimen, transverse direction; $r G$ or $K G=$ plane strain grooved specimen with material in transverse or as-ralled (b) $f(\phi t)=\sqrt[4]{1-e^{-6 \phi t}}$

(c) $f(Y S)=\Delta Y S / Y S$ Where $\beta=2.35 E-22$ reciprocal fluence and $\phi t=$ fluence $(n v) n / c m l^{2}$. Where $Y S=0.2 \%$ offset yield strength and $\Delta Y S=$ difference in yield strength for the irradiated and

(d) $f(U T S)=\Delta U T S / U T S$ non-irradiated condition only.

(e) Uniform elongation values for plane strain specimens estimated from RA values and considered to be excessively high. 
Table 9. TENSILE TEST RESULTS ON IRRADIATED SAXTON CORE II CLADDING (From Reference 25)

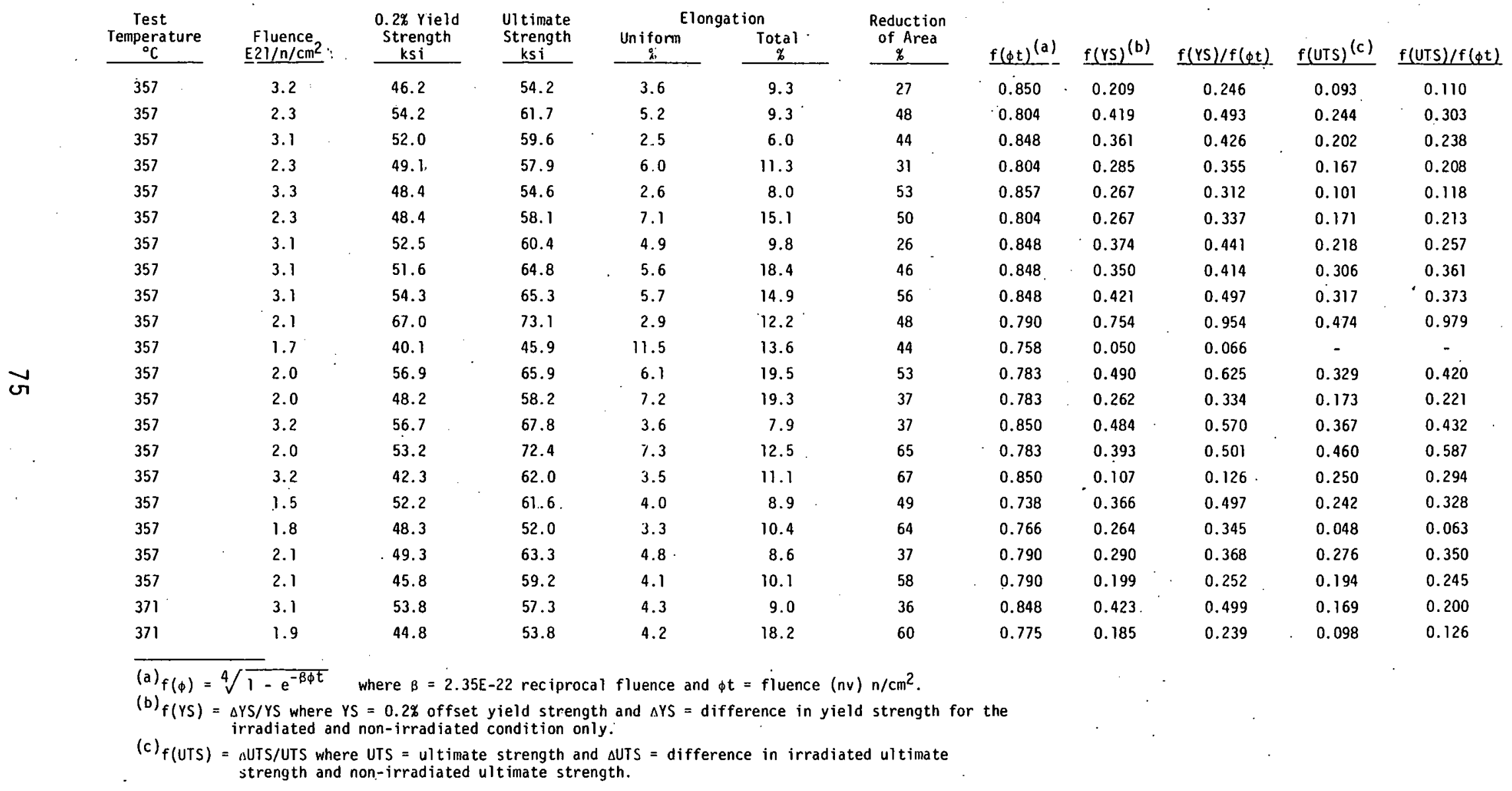


Table 10. POST IRRADIATION TENSILE PROPERTIÉS OF ZIRCALOY-2 AND -4

(From Reference 26)

\begin{tabular}{|c|c|c|c|c|c|c|c|c|c|c|c|c|}
\hline \multirow{2}{*}{$\begin{array}{l}\text { Material (A) } \\
\text { JoENTUTY }\end{array}$} & \multirow[b]{2}{*}{$\begin{array}{l}\text { FLUENCE } \\
\text { E21/NCMY }\end{array}$} & \multirow{2}{*}{$\begin{array}{c}\text { IEST } \\
\text { TEMPERATURE } \\
\left({ }^{\circ} \mathrm{C}\right) \\
\end{array}$} & \multirow{2}{*}{$\begin{array}{c}\text { YIELD } \\
\text { STRENGTH } \\
\text { (KSI) }\end{array}$} & \multirow{2}{*}{$\begin{array}{c}\text { ULTIMATE } \\
\text { STRENGTH } \\
\text { (KS.I) }\end{array}$} & \multicolumn{2}{|c|}{ ELONGATION } & \multirow{2}{*}{$\begin{array}{c}\text { REDUCTION } \\
\text { IN AREA } \\
\text { (\%) }\end{array}$} & \multirow[b]{2}{*}{$E(\phi \Gamma)^{(B)}$} & \multirow[b]{2}{*}{$E(y s)^{(c)}$} & \multirow[b]{2}{*}{$E(Y s) / E(\phi I)$} & \multirow[b]{2}{*}{ E(UIS) ${ }^{(D)}$} & \multirow[b]{2}{*}{$E(U T S) / F(\phi T)$} \\
\hline & & & & & $\begin{array}{c}\text { UNIFORM } \\
(\mathscr{G})\end{array}$ & $\begin{array}{c}\text { TotaL } \\
(\%)\end{array}$ & & & & & & \\
\hline$Z_{R}-4, A$ & 0 & Room & 48 & 73 & 15.0 & 22.9 & 41.5 & & & & & \\
\hline$Z R-4, A$ & 1.0 & Room & 79 & 90 & 3.7 & 11.4 & 36.6 & 0.676 & 0.655 & 0.969 & 0.223 & 0.337 \\
\hline$Z R-4, A$ & 1.4 & Room & 80 & 90 & 3.6 & 11.4 & 32.3 & 0.728 & 0.677 & 0.929 & $0.22 B$ & 0.337 \\
\hline$Z_{R}-2, A$ & 0 & Room & 45 & 70 & 16.7 & 26.3 & 39.9 & & & & & \\
\hline$Z R-2, A$ & 1.0 & Room & 82 & 89 & 3.2 & 12.3 & 39.1 & 0.676 & 0.810 & 1.198 & 0.265 & 0.392 \\
\hline$Z R-2, A$ & 1.4 & Room & 76 & 82 & 3.1 & 11.8 & 39.3 & 0.728 & 0.678 & 0.931 & 0.163 & 0.224 \\
\hline$Z_{R}-4, A$ & 0 & 150 & 35 & 56 & 13.0 & 23.9 & 42.1 & & & & & \\
\hline $2 R-4, A$ & 1.0 & 150 & 67 & 70 & $\cdot 2.8$ & 12.0 & 39.1 & 0.676 & 0.912 & 1.348 & 0.253 & 0.678 \\
\hline$Z R-4, A$ & 1.4 & 150 & 69 & 72 & 2.2 & 11.6 & 39.9 & 0.728 & 0.965 & 1.327 & 0.278 & 0.382 \\
\hline $2 R-4, A$ & 2.5 & 150 & 74 & 76 & 1.1 & 9.3 & 37.2 & 0.816 & 1.125 & 1.379 & 0.345 & 0.423 \\
\hline$Z R-4, A-E$ & 0 & 150 & 53 & 73 & 9.3 & 21.4 & 50.5 & & & & & \\
\hline$Z R-4, A-E$ & 1.0 & 150 & 82 & 87 & 1.5 & 11.2 & 49.2 & 0.676 & 0.526 & 0.778 & 0.186 & 0.275 \\
\hline$Z_{R}-4, A-E$ & 1.4 & 150 & 85 & 88 & 0.6 & 9.4 & 49.7 & 0.728 & 0.595 & 0.817 & 0.194 & 0.267 \\
\hline$Z_{R}-4, A-E$ & 2.5 & 150 & 93 & -95 & 0.7 & 8.8 & 46.3 & 0.816 & 0.743 & 0.911 & 0.289 & 0.354 \\
\hline$Z R-4, A-E \& H$ & !) & 150 & 55 & 72 & 6.9 & 20.7 & 45.6 & & & & & \\
\hline$Z_{R}-4, A-E \& H$ & 2.5 & 150 & 95 & 96 & 0.7 & 9.1 & 47.1 & 0.816 & 0.699 & 0.857 & 0.337 & 0.413 \\
\hline$Z_{R}-4, A 8 H$ & 0 & 150 & 34 & 54 & 11.2 & 24.6 & 40.3 & & & & & $\cdot$ \\
\hline$Z_{R}-4, A \& H$ & 2.5 & 150 & 71 & 74 & 1.5 & 10.0 & 39.1 & 0.816 & 1.051 & 1.288 & 0.377 & 0.462 \\
\hline$Z_{R}-4, A$ & 0 & 290 & 21 & 40 & 15.7 & 27.0 & 48.0 & & & & & \\
\hline$Z R-4, A$ & 1.0 & 290 & 49 & 49 & 0.6 & 13.7 & 50.9 & 0.676 & 1.320 & 1.954 & 0.211 & 0.313 \\
\hline$Z_{R}-4, A$. & 1.4 & 290 & 48 & 49 & 0.6 & 12.9 & 45.1 & 0.728 . & 1.321 & 1.814 & 0.211 & 0.313 \\
\hline$Z R-4, A$ & 2.5 & 290 & 59 & 59 & 0.2 & 10.0 & 42.4 & 0.816 & 1.783 & 2.185 & 0.453 & 0.555 \\
\hline
\end{tabular}

(a) Explanation of designations:

$A$ - Annealed

A-E - AS EXTRUDED

A-E\&H - As EXTRUDEd AND HYDRIDED TO 2300 PPM

(B) $F(\phi T)=\sqrt[4]{1-E^{-B \phi T}}$ WHERE $B=2.35 E-22$ RECIPROCAL FLUENCE AND $\phi T=$ FLUENCE (NV) $\mathrm{N} / \mathrm{CM}^{2}$.

(c) $F(Y S)=\Delta Y S / Y S$

WHERE YS $=0.2 \%$ OFFSET YIELD STRENGTH AND $\triangle Y S=$ DIFFERENCE IN YIELD STRENGTH FOR THE IRRADIATED AND NON-IRRADIATED CONDITION ONLY.

(D) F(UTS) = AUTS/UTS WHERE UTS = ULTIMATE STRENGTH AND AUTS = DIFFERENCE IN IRRADIATED ULTIMATE STRENGTH AND NON-IRRADIATED ULT IMATE STRENGTH. 


\section{Table 11. IN-FLUX AND POST-IRRADIATION TENSILE DATA FOR ZIRCALOY-4}

(From Reference 13)

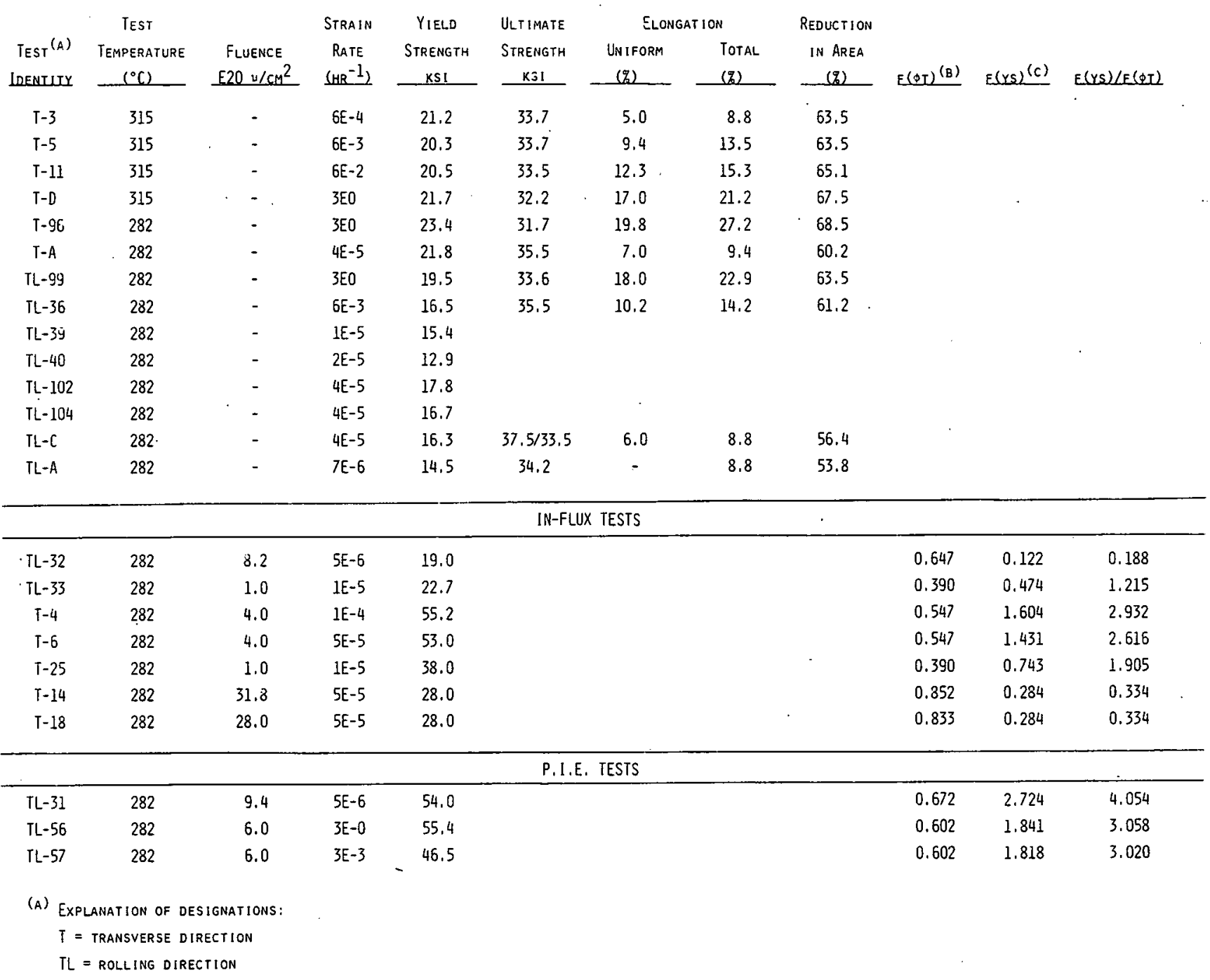

(B) $F(D T)=41-E^{-B \oplus T}$ HHERE $B=2.35 E-22$ RECIPROCAL FLUENCE AND DT $=$ FLUENCE $(N /) \mathrm{N} / \mathrm{CM}^{2}$.

(c) $F(Y S)=\triangle Y Y S Y Y S$ WHERE YS $=0.2 \%$ OFFSET YIEL STRENGTH AND DYS = DIFFERENCE IN YIELD STRENGTH FOR THE IRRADIATED AND NON-IRRADIATED CONDITION ONLY.

(D) $F(U T S)=$ SUTS/UTS WHERE UTS = ULTIMATE STRENGTH AND SUTS = DIFFERENCE IN IRRADIATED ULTIMATE STRENGTH AND NON-IRRADIATED ULTIMATE STRENGTH. 
Table 12. TENSILE TEST DATA OF IRRADIATED AND UNIRRADIATED ZIRCONIUM-2.5 WT\% NIOBIUM (From Reference 23)

\begin{tabular}{|c|c|c|c|c|c|c|c|c|c|c|c|c|c|c|c|c|c|c|}
\hline \multirow{2}{*}{$\begin{array}{r}\text { Material } \\
\text { Condition (a) } \\
\end{array}$} & \multirow{2}{*}{$\begin{array}{l}\text { Fast Fluence, } \\
\mathrm{E} 20 \mathrm{n} / \mathrm{cm}^{2}\end{array}$} & \multirow{2}{*}{$\begin{array}{r}\text { Irr. } \\
\text { Temp. } \\
-\quad C \\
\end{array}$} & \multirow{2}{*}{$\begin{array}{c}\text { Test } \\
\text { Temp. } \\
\text { c. } \\
\end{array}$} & \multicolumn{2}{|c|}{$\begin{array}{l}\text { rield Strength } \\
\mathrm{ksi}\end{array}$} & \multicolumn{2}{|c|}{ U]timate Strength } & \multicolumn{4}{|c|}{$\begin{array}{l}\text { Elongation, } \\
\text { Uniform }\end{array}$} & \multirow{2}{*}{\multicolumn{2}{|c|}{$\begin{array}{l}\text { Reduction in } \\
\text { Area, \& } \\
\text { Unirr. Irr. }\end{array}$}} & \multirow[b]{2}{*}{$f(\phi t)^{(b)}$} & \multirow[b]{2}{*}{$f(r s)^{(c)}$} & \multirow[b]{2}{*}{$f(Y s) / f(\phi t)$} & \multirow[b]{2}{*}{$\underline{f(U T S)^{(d)}}$} & \multirow[b]{2}{*}{$f(U T S) / f(\phi t)$} \\
\hline & & & & Unirr. & Irr. & Untrr. & Irr. & Unirr. & Irr. & Unirr. & Irr. & & & & & & & \\
\hline$Q-B, A-500$ & 3 & $250-325$ & RT & 113 & 153 & 170 & 160 & 4 & $<1$ & 10 & 1 & $>25$ & $>5$ & 0.510 & 0.354 & 0.694 & - & - \\
\hline$A-B, A-500$ & 1 & 250 & 300 & 85 & 97 & 93 & 102 & - & - & 14.2 & 13.3 & - & $\cdot$ & 0.390 & 0.141 & 0.362 & 0.097 & 0.248 \\
\hline Q-B, A-500 & 3 & $250-325$ & 300 & 81 & 114 & 133 & 126 & 3 & 1.5 & 12 & 2 & 56 & $<20$ & 0.510 & 0.407 & 0.800 & - & - \\
\hline $\mathrm{SC}-8,40 \mathrm{CW}$ & 3 & $250-325$ & RT & 97 & 131 & 122 & 152 & 1 & 1 & - & - & 30 & 26 & 0.510 & 0.351 & 0.687 & 0.245 & 0.482 \\
\hline $\mathrm{SC}-\mathrm{B}, 40 \mathrm{CW}$ & 3 & $250-325$ & 300 & 60 & 101 & 90 & 116 & 1 & 1 & - & - & 34 & 26 & 0.510 & 0.683 & 1.340 & 0.289 & 0.566 \\
\hline$Q-8, A-500$ & 1 & 250 & RT & - & 136 & - & 142 & - & - & - & 10.5 & - & - & - & - & $=$ & - & - \\
\hline$S C-(A+B)$ & 3 & $250-325$ & RT & 61 & 107 & 132 & 150 & 12 & 3.0 & - & - & 56 & 37 & 0.610 & 0.754 & 1.478 & 0.136 & 0.267 \\
\hline$S C-(A+B)$ & 3 & $250-325$ & 300 & 32 & 80 & 100 & - 120 & 18 & 2.0 & 30 & 11 & 72 & 60 & 0.510 & 1.500 & 2.941 & 0.200 & 0.392 \\
\hline SC-B & 3 & $250-325$ & RT & 73 & 100 & 130 & 123 & 9 & 10 & - & - & 44 & 13 & 0.510 & 0.370 & 0.725 & - & - \\
\hline SC-B & 3 & $250-325$ & 300 & 34 & 68 & 92 & 120 & 5 & 4 & 12 & 9 & 67 & 40 & 0.510 & 1.000 & 1.960 & 0.304 & 0.596 \\
\hline$Q-(A+B)$ & 3 & $250-32 E$ & RT & 109 & 142 & 194 & 210 & 4 & 1 & - & - & 60 & 55 & 0.510 & 0.303 & 0.594 & 0.082 & 0.162 \\
\hline A-500. & 3 & $250-325$ & 300 & 85 & 116 & 167 & 175 & 3 & $<1$ & 12 & 11 & 70 & 65 & 0.510 & 0.365 & 0.715 & 0.048 & 0.094 \\
\hline Q-8 & 1 & 250 & 300 & 77 & 108 & 87 & 115 & - & - & 14.5 & 11.3 & - & - & 0.390 & 0.403 & 1.032 & 0.322 & 0.825 \\
\hline
\end{tabular}

(a) Explanation of designations: $\mathrm{SC}$ - slow cooled 0- quenched $(A+B)$ - from (alpha + beta) phase $A-500-$ annealed at $500^{\circ} \mathrm{C}$ B - from beta phase 
Table 13. TENSILE PROPERTIES OF THE $\mathrm{Zr}-2.5$ WT\% Nb ALLOY IN VARIOUS METALLURGICAL CONDITIONS (From Reference 23)

\begin{tabular}{|c|c|c|c|c|c|c|c|c|c|c|c|}
\hline $\begin{array}{l}\text { Metallurgical } \\
\text { Condition }\end{array}$ & $\begin{array}{l}\text { Irradiation (a) } \\
\text { History } \\
\end{array}$ & $\begin{array}{l}\text { Test } \\
\text { Temp } \\
{ }^{\circ} \mathrm{C} \\
\end{array}$ & $\begin{array}{c}\text { Yield } \\
\text { Strength } \\
\text { ksi }\end{array}$ & $\begin{array}{l}\text { Ultimate } \\
\text { Strength } \\
\text { ksi } \\
\end{array}$ & $\begin{array}{l}\text { Elong. } \\
\text { Uniform। } \\
\% \\
\end{array}$ & $\begin{array}{c}\text { Reduction } \\
\text { in Area } \\
\% \\
\end{array}$ & $\underline{f(\phi t)})^{(b)}$ & $f(Y S)^{(c)}$ & $\frac{f(Y S)}{f(\phi t)}$ & $\underline{f(U T S)^{(d)}}$ & $\frac{f(U T S)}{f(\phi t)}$ \\
\hline $\begin{array}{l}\text { Slow cooled } \\
\text { from }(\alpha+\beta) \\
\text { phase }\end{array}$ & $\begin{array}{l}\text { Unirradiated } \\
\text { Irradiated } \\
\text { Unirradiated } \\
\text { Irradiated }\end{array}$ & $\begin{array}{l}\text { RT } \\
\text { RT } \\
300 \\
300\end{array}$ & $\begin{array}{r}61 \\
107 \\
32 \\
80\end{array}$ & $\begin{array}{l}132 \\
150 \\
100 \\
120\end{array}$ & $\begin{array}{r}12 \\
3 \\
18 \\
2\end{array}$ & $\begin{array}{l}56 \\
37 \\
72 \\
60\end{array}$ & 0.510 & $\begin{array}{l}-- \\
0 . \overline{754} \\
-\overline{500}\end{array}$ & $\begin{array}{l}-- \\
1.476 \\
-- \\
2.937\end{array}$ & $\begin{array}{l}-- \\
0.136 \\
-\overline{0} \\
0.167\end{array}$ & $\begin{array}{l}-\overline{-} \\
0.267 \\
\overline{--} \\
0.326\end{array}$ \\
\hline $\begin{array}{l}\text { Slow cooled } \\
\text { from } \beta \text {-phase }\end{array}$ & $\begin{array}{l}\text { Unirradiated } \\
\text { Irradiated } \\
\text { Unirradiated } \\
\text { Irradiated }\end{array}$ & $\begin{array}{l}\text { RT } \\
\text { RT } \\
300 \\
300\end{array}$ & $\begin{array}{r}73 \\
100 \\
34 \\
68\end{array}$ & $\begin{array}{r}130 \\
123 \\
92 \\
120\end{array}$ & $\begin{array}{r}9 \\
10 \\
5 \\
4\end{array}$ & $\begin{array}{l}44 \\
13 \\
67 \\
40\end{array}$ & & $\begin{array}{c}-- \\
0.370 \\
-- \\
1.000\end{array}$ & $\begin{array}{l}-- \\
0.724 \\
-- \\
1.958\end{array}$ & $\begin{array}{c}-- \\
-- \\
0 . \overline{304}\end{array}$ & $\begin{array}{c}-- \\
-- \\
0.596\end{array}$ \\
\hline $\begin{array}{l}\text { Quenched } \\
\text { from }(\alpha+\beta) \\
\text { phase and aged } \\
24 \mathrm{hr} \text { at } 500^{\circ} \mathrm{C}\end{array}$ & $\begin{array}{l}\text { Unirradiated } \\
\text { Irradiated } \\
\text { Unirradiated } \\
\text { Irradiated }\end{array}$ & $\begin{array}{l}\text { RT } \\
\text { RT } \\
300 \\
300\end{array}$ & $\begin{array}{r}109 \\
142 \\
85 \\
116\end{array}$ & $\begin{array}{l}194 \\
210 \\
167 \\
175\end{array}$ & $\begin{array}{r}4 \\
1 \\
3 \\
<1\end{array}$ & $\begin{array}{l}60 \\
55 \\
70 \\
65\end{array}$ & & $\begin{array}{l}-- \\
0 . \overline{303} \\
\overline{-} \\
0.365\end{array}$ & $\begin{array}{l}-- \\
0.592 \\
-- \\
0.714\end{array}$ & $\begin{array}{c}\overline{--} \\
0.083 \\
-- \\
0.058\end{array}$ & $\begin{array}{l}0 . \overline{161} \\
\overline{0.114}\end{array}$ \\
\hline $\begin{array}{l}\text { Quenched } \\
\text { from } \beta \text {-phase } \\
\text { and aged } \\
24 \mathrm{hr} \text { at } 500^{\circ} \mathrm{C}\end{array}$ & $\begin{array}{l}\text { Unirradiated } \\
\text { Irradiated } \\
\text { Unirradiated } \\
\text { Irradiated }\end{array}$ & $\begin{array}{l}\text { RT } \\
\text { RT } \\
300 \\
300\end{array}$ & $\begin{array}{r}113 \\
153 \\
81 \\
114\end{array}$ & $\begin{array}{l}170 \\
160 \\
133 \\
126\end{array}$ & $\begin{array}{r}4 \\
<1 \\
3 \\
1.5\end{array}$ & $\begin{array}{r}>25 \\
<5 \\
56 \\
<20\end{array}$ & & $\begin{array}{c}-\overline{-} \\
0.354 \\
-- \\
0.407\end{array}$ & $\begin{array}{l}-\overline{0} \\
0.693 \\
-- \\
0.798\end{array}$ & $\begin{array}{l}-- \\
-- \\
--\end{array}$ & $\begin{array}{l}-- \\
-- \\
--\end{array}$ \\
\hline $\begin{array}{l}\text { Cold drawn } \\
40 \% \text { after } \\
\text { slow cooling } \\
\text { from }(\alpha+\beta)\end{array}$ & $\begin{array}{l}\text { Unirradiated } \\
\text { Irradiated } \\
\text { Unirradiated } \\
\text { Irradiated }\end{array}$ & $\begin{array}{l}\text { RT } \\
\text { RT } \\
300 \\
300\end{array}$ & $\begin{array}{r}97 \\
131 \\
60 \\
101\end{array}$ & $\begin{array}{r}122 \\
152 \\
90 \\
116\end{array}$ & $\begin{array}{l}1 \\
1 \\
1 \\
1\end{array}$ & $\begin{array}{l}30 \\
26 \\
34 \\
26\end{array}$ & & $\begin{array}{c}0 . \overline{351} \\
\overline{--} \\
0.683\end{array}$ & $\begin{array}{l}-- \\
0.686 \\
-- \\
1.338\end{array}$ & $\begin{array}{c}\overline{--} \\
0.246 \\
-\overline{-} \\
0.289\end{array}$ & $\begin{array}{c}-- \\
0.481 \\
-- \\
0.566\end{array}$ \\
\hline
\end{tabular}

(a) AW Material. Irradiated specimens were at $250^{\circ}-325^{\circ} \mathrm{C}$ during irradiation to $3 \times 10^{20} \mathrm{n} / \mathrm{cm}^{2}$

(b) $f(\phi t)=\sqrt[4]{1-e^{-\beta \phi t}}$ where $\beta=2.35 E-22$ reciprocal fluence and $\phi t=$ fluence $(\mathrm{nv}) \mathrm{n} / \mathrm{cm}^{2}$.

(c) $f(Y S)=\Delta Y S / Y S$ where $Y S=0.2 \%$ offset yield strength and $\Delta Y S=$ difference in yield strength for the irradiated and non-irradiated condition only.

(d) $f(U T S)=\Delta U T S / U T S$ where UTS = ultimate strength and $\Delta$ UTS = difference in irradiated ultimate strength and non-irradiated ultimate strength. 
Table 14a. ROOM TEMPERATURE TENSILE DATA FOR Zr ALLOYS IRRADIATED TO $\sim$ E $19 \mathrm{n} / \mathrm{cm}^{2}$

\begin{tabular}{|c|c|c|c|c|c|c|c|c|c|c|c|c|}
\hline \multirow{2}{*}{ 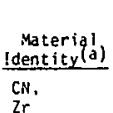 } & & $\begin{array}{l}\text { Irradiation } \\
\text { Temperarature }\end{array}$ & $\begin{array}{c}\begin{array}{c}\text { yeld } \\
\text { strength } \\
\text { ksi }\end{array} \\
\end{array}$ & 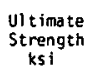 & & $\begin{array}{l}\text { Reduction } \\
\text { of Area }\end{array}$ & $\begin{array}{l}\text { Strain } \\
\text { Hardenability }\end{array}$ & & tryst & & $\frac{f}{f(t)}$ \\
\hline & $\frac{\text { oirection }}{\mathrm{t}}$ & 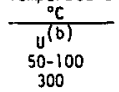 & $\begin{array}{l}\mathrm{ksi} \\
12.0 \\
33.0 \\
24.9\end{array}$ & $\begin{array}{l}\mathbf{k s 1} \\
27.0 \\
34.1 \\
3.1\end{array}$ & $\frac{8}{29}$ & $\begin{array}{l}\frac{8}{35} \\
11 \\
17\end{array}$ & $\begin{array}{l}8 \\
62 \\
62 \\
54\end{array}$ & 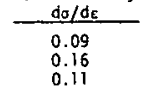 & $\frac{f(Y 5)^{(c)}}{\frac{f(1.750}{1.075}}$ & 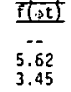 & $\begin{array}{l}\frac{f(U T S)^{(d)}}{--} \\
0.259 \\
0.226\end{array}$ & $\begin{array}{l}0.83 \\
0.73\end{array}$ \\
\hline & $T$ & $\begin{array}{c}0 \\
500100 \\
300\end{array}$ & $\begin{array}{l}20.0 \\
41.5 \\
33.1\end{array}$ & $\begin{array}{l}29.0 \\
41.5 \\
33.1\end{array}$ & $\begin{array}{c}18 \\
0 \\
6\end{array}$ & $\begin{array}{c}22 \\
8 \\
13\end{array}$ & $\begin{array}{l}68 \\
61 \\
66 \\
66\end{array}$ & $\begin{array}{l}0.09 \\
0.11 \\
0.11\end{array}$ & $\begin{array}{l}1.075 \\
0.655\end{array}$ & $\begin{array}{l}5.62 \\
2.11\end{array}$ & $\begin{array}{l}0.431 \\
0.441\end{array}$ & $\begin{array}{l}1.39 \\
0.45 \\
0.45\end{array}$ \\
\hline 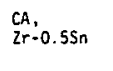 & L & $\underset{50-100}{500}$ & $\begin{array}{l}14.9 \\
335.1 \\
38.0\end{array}$ & $\begin{array}{l}33.1 \\
33.0 \\
40.0\end{array}$ & $\begin{array}{r}32 \\
3 \\
2\end{array}$ & $\begin{array}{l}43^{\circ} \\
25 \\
23\end{array}$ & $\begin{array}{l}62 \\
622 \\
63\end{array}$ & $\begin{array}{l}0.10 \\
0.14 \\
0.15\end{array}$ & $\begin{array}{l}0.356 \\
1.550\end{array}$ & $\begin{array}{l}4.36 \\
4.98\end{array}$ & $\begin{array}{l}0.148 \\
0.208\end{array}$ & $\begin{array}{l}0.48 \\
0.67\end{array}$ \\
\hline & $\tau$ & $\begin{array}{c}\qquad 0 \\
50-100 \\
300\end{array}$ & $\begin{array}{l}30.0 \\
49.0 \\
42.1\end{array}$ & $\begin{array}{l}40.2 \\
48.0 \\
43.1\end{array}$ & $\begin{array}{r}2 ! \\
0 \\
4\end{array}$ & $\begin{array}{l}32 \\
11 \\
21\end{array}$ & $\begin{array}{l}72 \\
70 \\
73\end{array}$ & $\begin{array}{l}0.10 \\
0.07\end{array}$ & $\begin{array}{l}-. . \\
0.633 \\
0.043\end{array}$ & $\begin{array}{l}2.04 \\
1.30\end{array}$ & $\begin{array}{l}0.199 \\
0.042\end{array}$ & .23 \\
\hline $28.0 .14 N b$ & l & $\begin{array}{c}\mathrm{U} \\
50-100 \\
300\end{array}$ & $\begin{array}{l}14.92 \\
41.2 \\
39.6\end{array}$ & $\begin{array}{l}32.2 \\
\text { at. } \\
48.0\end{array}$ & $\begin{array}{r}35 \\
4 \\
3\end{array}$ & $\begin{array}{l}43 \\
15 \\
12\end{array}$ & $\begin{array}{l}66 \\
58 \\
57\end{array}$ & $\begin{array}{l}0.09 \\
0.221 \\
0.35\end{array}$ & $\begin{array}{l}1.765 \\
1.658\end{array}$ & $\begin{array}{l}5.67 \\
5.33\end{array}$ & $\begin{array}{l}0.307 \\
0.491\end{array}$ & 0.58 \\
\hline & $\tau$ & $\begin{array}{c}50-100 \\
300 \\
300\end{array}$ & $\begin{array}{l}26.5 \\
47.0 \\
41.0\end{array}$ & $\begin{array}{l}36.4 \\
47.0 \\
47.0\end{array}$ & $\begin{array}{l}24 \\
0 \\
11\end{array}$ & $\begin{array}{c}38 \\
9 \\
22\end{array}$ & $\begin{array}{l}74 \\
69 \\
66\end{array}$ & $\begin{array}{c}0.09 \\
0.11 \\
0.11\end{array}$ & $\begin{array}{l}0.774 \\
0.547\end{array}$ & $\begin{array}{l}2.49 \\
1.76\end{array}$ & $\begin{array}{l}0.291 \\
0.291\end{array}$ & 0.94 \\
\hline 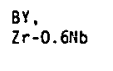 & I & $\begin{array}{c}50-100 \\
300\end{array}$ & $\begin{array}{l}16.0 \\
46.0 \\
55.8\end{array}$ & $\begin{array}{l}37.0 \\
50.0 \\
68.0\end{array}$ & $\begin{array}{r}20 \\
3 \\
4\end{array}$ & $\begin{array}{r}26 \\
6 \\
8\end{array}$ & $\begin{array}{l}54 \\
44 \\
44\end{array}$ & $\begin{array}{l}0.16 \\
0.20 \\
0.40\end{array}$ & $\begin{array}{l}1.075 \\
2.488\end{array}$ & $\begin{array}{l}6.03 \\
8.00\end{array}$ & $\begin{array}{l}0 . \overline{351} \\
0.838\end{array}$ & $\begin{array}{l}1.13 \\
2.69\end{array}$ \\
\hline & $\tau$ & $\begin{array}{c}50-100 \\
50100 \\
300 .\end{array}$ & $\begin{array}{l}36.0 \\
59.0 \\
51.0\end{array}$ & $\begin{array}{l}46.7 \\
67.0 \\
85.0\end{array}$ & $\begin{array}{r}21 \\
3 \\
5\end{array}$ & $\begin{array}{r}39 \\
9 \\
10\end{array}$ & $\begin{array}{l}69 \\
57 \\
46\end{array}$ & $\begin{array}{l}0.16 \\
0.17 \\
0.41\end{array}$ & $\begin{array}{c}0.639 \\
0.417 \\
0.417\end{array}$ & $\begin{array}{l}2.054 \\
1.341\end{array}$ & $\begin{array}{l}0 . \overline{434} \\
0.320\end{array}$ & $\frac{1}{2}$ \\
\hline $\begin{array}{l}8 \mathrm{Bx}, \\
2 \mathrm{r}-2.35 \mathrm{Nb}\end{array}$ & L & $\begin{array}{c}50 \\
50-100 \\
300\end{array}$ & $\begin{array}{l}24.9 \\
64.1 \\
69.9\end{array}$ & $\begin{array}{l}46.7 \\
567.0 \\
85.0\end{array}$ & $\begin{array}{r}21 \\
3 \\
5\end{array}$ & $\begin{array}{c}39 \\
9 \\
10\end{array}$ & $\begin{array}{l}69 \\
57 \\
46\end{array}$ & $\begin{array}{l}0.16 \\
0.17 \\
0.41\end{array}$ & $\begin{array}{l}\because .574 \\
1.807\end{array}$ & $\begin{array}{l}5.06 \\
5.81\end{array}$ & $\begin{array}{l}0 . \ddot{435} \\
0.820\end{array}$ & 40 \\
\hline & $T$ & $\begin{array}{c}0 \\
50-100 \\
300\end{array}$ & $\begin{array}{l}43.8 \\
88.0 \\
99.0\end{array}$ & $\begin{array}{l}52.5 \\
81.0 \\
88.1\end{array}$ & $\begin{array}{l}5 \\
0 \\
4\end{array}$ & $\begin{array}{l}10 \\
5 \\
9\end{array}$ & $\begin{array}{l}43 \\
53 \\
32\end{array}$ & $\begin{array}{l}0.23 \\
0.25\end{array}$ & $\begin{array}{l}0.8449 \\
0.804\end{array}$ & $\begin{array}{l}2.73 \\
2.79\end{array}$ & $\begin{array}{l}0.343 \\
0.621\end{array}$ & \\
\hline $\begin{array}{l}\frac{85}{2 r} \\
2 r\end{array}$ & L & $\begin{array}{c}\mathbf{U} \\
50-100 \\
300 \\
300\end{array}$ & $\begin{array}{l}124.5 \\
24.8 \\
23.1\end{array}$ & $\begin{array}{l}27.6 \\
27.8 \\
27.8\end{array}$ & $\begin{array}{c}33 \\
10 \\
9\end{array}$ & $\begin{array}{l}41 \\
25 \\
30\end{array}$ & $\begin{array}{l}57 \\
58 \\
61\end{array}$ & $\begin{array}{l}0.08 \\
0.06 \\
0.06\end{array}$ & $\begin{array}{l}0.98{ }^{\circ} \\
0.0888\end{array}$ & $\begin{array}{l}3.16 \\
3.16 \\
2.73\end{array}$ & $\because$ & \\
\hline & $T$ & $\begin{array}{c}5 \\
50-100 \\
300\end{array}$ & $\begin{array}{l}18.4 \\
33.5 \\
27.6\end{array}$ & $\begin{array}{l}31.2 \\
33.0 \\
34.4\end{array}$ & $\begin{array}{l}24 \\
12 \\
19\end{array}$ & $\begin{array}{l}34 \\
27 \\
32\end{array}$ & $\begin{array}{l}65 \\
69 \\
69\end{array}$ & $\begin{array}{l}0.09 \\
0.05 \\
0.08\end{array}$ & $\begin{array}{l}-. .221 \\
0.6000\end{array}$ & $\begin{array}{l}2.64 \\
1.93\end{array}$ & $\begin{array}{l}0 . \ddot{1322} \\
0.103\end{array}$ & $\begin{array}{l}0.3 \\
0.3\end{array}$ \\
\hline $\begin{array}{l}\frac{800}{20}-2 \\
2 r-2\end{array}$ & L & $\begin{array}{c}50 \\
50-100 \\
300\end{array}$ & $\begin{array}{l}48.4 \\
68.6 \\
61.1\end{array}$ & $\begin{array}{l}69.9 \\
78.6 \\
75.4\end{array}$ & $\begin{array}{r}13 \\
4 \\
6\end{array}$ & $\begin{array}{l}24 \\
16 \\
19\end{array}$ & $\begin{array}{l}41 \\
35 \\
44\end{array}$ & $\begin{array}{l}0.25 \\
0.35 \\
0.33\end{array}$ & $\begin{array}{l}0.417 \\
0.262\end{array}$ & $\begin{array}{l}1.34 \\
0.84\end{array}$ & $\begin{array}{l}0.124 \\
0.079\end{array}$ & $\begin{array}{l}0.4 \\
0.2\end{array}$ \\
\hline & $T$ & $\begin{array}{l}.50-100 \\
300\end{array}$ & $\begin{array}{l}68.7 \\
89.6 \\
80.2\end{array}$ & $\begin{array}{l}74.4 \\
89.6 \\
80.1\end{array}$ & $\begin{array}{l}9 \\
0 \\
0.5\end{array}$ & $\begin{array}{c}19 \\
8 \\
13\end{array}$ & $\begin{array}{l}46 \\
50 \\
46\end{array}$ & $\begin{array}{c}0.14 \\
\because-\end{array}$ & $\begin{array}{l}\ddot{0.304} \\
0.167\end{array}$ & $\begin{array}{l}-. .98 \\
0.98 \\
0.54\end{array}$ & $\begin{array}{l}0 . \ddot{205} \\
0.076\end{array}$ & $\begin{array}{l}0.6 \\
0.2\end{array}$ \\
\hline 量 & L & $\begin{array}{c}50 \\
50-100 \\
300\end{array}$ & $\begin{array}{l}56.1 \\
86.0 \\
87.0\end{array}$ & $\begin{array}{r}73.0 \\
99.5 \\
102.1\end{array}$ & $\begin{array}{r}14 \\
3 \\
6\end{array}$ & $\begin{array}{c}28 \\
14 \\
13\end{array}$ & $\begin{array}{l}60 \\
51 \\
35\end{array}$ & $\begin{array}{l}0.21 \\
0.224 \\
0.37\end{array}$ & $\begin{array}{l}0.533 \\
0.551 \\
0.551\end{array}$ & $\begin{array}{l}.7 .71 \\
1.77\end{array}$ & $\begin{array}{l}0.254 \\
0.3999\end{array}$ & 0. \\
\hline & $T$ & $\begin{array}{c}50 \\
50-100 \\
300\end{array}$ & $\begin{array}{l}76.3 \\
107.0 \\
108.1\end{array}$ & $\begin{array}{r}80.6 \\
107.0 \\
10.0\end{array}$ & $\begin{array}{l}? \\
0.5 \\
6\end{array}$ & $\begin{array}{c}16 \\
6 \\
11\end{array}$ & $\begin{array}{l}47 \\
42 \\
35\end{array}$ & $\begin{array}{l}0.16 \\
0.18\end{array}$ & $\begin{array}{l}-. \overline{403} \\
0.415 \\
0.415\end{array}$ & $\underset{1.30}{1.30}$ & $\begin{array}{l}0 . \overline{328} \\
0.3666 \\
0.36\end{array}$ & 1.1 \\
\hline
\end{tabular}

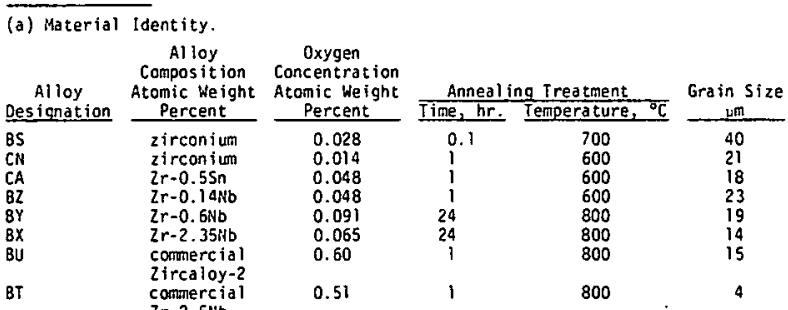

(b) $U=$ Unirradiated

(c) $f(Y S)=\Delta Y S / Y S$ where $Y S=0.2 \%$ offset yield strength and $\Delta Y S=$ difference in yield strength for the

(d) $f(U T S)=\Delta U T S / U T S$ where UTS = ul timate strength and $\Delta$ UTS = difference in ultimate strength for the 
$\begin{array}{ll}\text { Table 14b. } & 300^{\circ} \mathrm{C} \text { TENSILE DATA FOR } \mathrm{Zr} \text { ALLOYS } \\ & \text { IRRADIATED TO } \sim 7 \mathrm{ET} 9 \mathrm{n} / \mathrm{cm}^{2} \\ & \text { (From Reference } 27 \text { ) }\end{array}$

\begin{tabular}{|c|c|c|c|c|c|c|c|c|c|c|c|c|}
\hline $\begin{array}{c}\text { Material } \\
\text { Identity }(a)\end{array}$ & $\begin{array}{c}\text { Test ing } \\
\text { Direction }\end{array}$ & $\begin{array}{l}\text { Irradiation } \\
\text { Temperature } \\
{ }_{0} \mathrm{c}\end{array}$ & $\begin{array}{c}\text { Yield } \\
\text { Strength } \\
\text { ksi } \\
\end{array}$ & $\begin{array}{c}\text { Ultimate } \\
\text { Strength } \\
\text { ksi } \\
\end{array}$ & $\begin{array}{c}\text { Elong } \\
\text { Uniform } \\
\quad \% \\
\end{array}$ & $\begin{array}{l}\text { ion } \\
\text { Tota } 1 \\
x \\
\end{array}$ & $\begin{array}{c}\text { Reduct ion } \\
\text { of Area } \\
\quad x \\
\end{array}$ & $\begin{array}{l}\text { Strain } \\
\text { Hardenability } \\
\quad \mathrm{do} / \mathrm{d} \varepsilon \\
\end{array}$ & $f(Y S)^{(c)}$ & $\frac{f(Y S)}{f(g t)}$ & $\underline{f(U T S)^{(d)}}$ & $\frac{f(U I S)}{f(t, t)}$ \\
\hline \multirow[t]{2}{*}{$\begin{array}{l}\mathrm{CN} . \\
\mathrm{Zr}\end{array}$} & $\mathrm{L}$ & $\begin{array}{l}u^{(\delta)} \\
300\end{array}$ & $\begin{array}{l}7.3 \\
20.0\end{array}$ & $\begin{array}{l}15.7 \\
20.7\end{array}$ & & & $\begin{array}{l}85 \\
85\end{array}$ & $\begin{array}{l}0.07 \\
0.08\end{array}$ & $\overline{1.740}$ & $\overline{5.59}$ & $\overline{0.318}$ & $\overline{1.02}$ \\
\hline & $T$ & $\begin{array}{l}u \\
300\end{array}$ & $\begin{array}{r}9.9 \\
22.5\end{array}$ & $\begin{array}{l}15.7 \\
22.5\end{array}$ & $\begin{array}{l}8.5 \\
0\end{array}$ & $\begin{array}{l}18 \\
10\end{array}$ & $\begin{array}{l}83 \\
84\end{array}$ & $\begin{array}{c}0.09 \\
-\end{array}$ & 1.273 & $\ddot{4.09}$ & 0.0 .433 & $\because .39$ \\
\hline \multirow[t]{2}{*}{$\begin{array}{l}C A, \\
2 r-0.55 n\end{array}$} & L & $U_{300}$ & $\begin{array}{r}8.6 \\
23.4\end{array}$ & $\begin{array}{l}19.0 \\
27.0\end{array}$ & $\begin{array}{r}29 \\
0\end{array}$ & $\begin{array}{l}41 \\
14\end{array}$ & $\begin{array}{l}85 \\
83\end{array}$ & 0.06 & 1.720 & $\ddot{5.53}$ & 0.421 & 1.35 \\
\hline & $\mathrm{T}$ & $U_{300}^{U}$ & $\begin{array}{l}14.9 \\
30.5\end{array}$ & $\begin{array}{l}21.0 \\
30.9\end{array}$ & $\begin{array}{r}10 \\
0\end{array}$ & $\begin{array}{l}22 \\
11\end{array}$ & $\begin{array}{l}85 \\
88\end{array}$ & 0.08 & 1.047 & $3 .-37$ & 0.471 & $1 . .52$ \\
\hline \multirow[t]{2}{*}{$\begin{array}{l}82 \\
2 r=0.14 N \mathrm{ND}\end{array}$} & L & $\begin{array}{l}u \\
300\end{array}$ & $\begin{array}{r}6.8 \\
27.7\end{array}$ & $\begin{array}{l}16.7 \\
31.2\end{array}$ & $\begin{array}{r}27 \\
2\end{array}$ & $\begin{array}{l}41 \\
11\end{array}$ & $\begin{array}{l}87 \\
86\end{array}$ & $\begin{array}{l}0.06 \\
0.27\end{array}$ & 3.07 & 9.88 & 0.868 & 2.79 \\
\hline & $T$ & $\begin{array}{l}U \\
300\end{array}$ & $\begin{array}{l}10.7 \\
31.1\end{array}$ & $\begin{array}{l}17.5 \\
31.6\end{array}$ & $\begin{array}{l}13 \\
0.5\end{array}$ & $\begin{array}{l}25 \\
10\end{array}$ & $\begin{array}{l}90 \\
88\end{array}$ & $\begin{array}{l}0.07 \\
0.14\end{array}$ & 1.906 & 6.13 & 0.805 & 2.59 \\
\hline \multirow[t]{2}{*}{$\frac{\mathrm{BY}}{\mathrm{Z}-0.6 \mathrm{Nb}}$} & L & $\begin{array}{l}U \\
300\end{array}$ & $\begin{array}{r}9.3 \\
42.1\end{array}$ & $\begin{array}{l}20.6 \\
49.2\end{array}$ & $\begin{array}{r}25 \\
3\end{array}$ & $\begin{array}{l}34 \\
10\end{array}$ & $\begin{array}{l}80 \\
76\end{array}$ & $\begin{array}{l}0.07 \\
0.03\end{array}$ & 3.527 & $\ddot{11.3}$ & 1.388 & 4.46 \\
\hline & $T$ & $\begin{array}{l}\text { u. } \\
300\end{array}$ & $\begin{array}{l}16.1 \\
42.5\end{array}$ & $\begin{array}{l}21.5 \\
46.2\end{array}$ & $\begin{array}{l}7 \\
6\end{array}$ & $\begin{array}{l}16 \\
14\end{array}$ & $\begin{array}{l}78 \\
80\end{array}$ & $\begin{array}{l}0.10 \\
0.50\end{array}$ & 1.640 & 5.27 & 1.149 & 3.69 \\
\hline \multirow[t]{2}{*}{$\begin{array}{l}\mathrm{BX} \\
\mathrm{Zr}-2.35 \mathrm{Nb}\end{array}$} & L & $U_{300}^{U}$ & $\begin{array}{l}14.8 \\
35.1\end{array}$ & $\begin{array}{l}31.8 \\
64.5\end{array}$ & $\begin{array}{l}20 \\
3.5\end{array}$ & $\begin{array}{r}17 \\
9\end{array}$ & $\begin{array}{l}90 \\
75\end{array}$ & $\begin{array}{l}0.13 \\
0.31\end{array}$ & 1.372 & $\overline{4.41}$ & 1.028 & 3.30 \\
\hline & $T$ & $\begin{array}{l}U \\
300\end{array}$ & $\begin{array}{l}19.9 \\
61.5\end{array}$ & $\begin{array}{l}32.5 \\
66.4\end{array}$ & $\begin{array}{l}7 \\
2\end{array}$ & $\begin{array}{r}16 \\
9\end{array}$ & $\begin{array}{l}87 \\
78\end{array}$ & $\begin{array}{l}0.20 \\
0.29\end{array}$ & 2.090 & 6.72 & $1 .-043$ & 3.35 \\
\hline \multirow[t]{2}{*}{$\begin{array}{l}\text { BS } \\
2 r\end{array}$} & L & $\begin{array}{l}U \\
300\end{array}$ & $\begin{array}{r}5.1 \\
13.6\end{array}$ & $\begin{array}{l}14.2 \\
15.1\end{array}$ & $\begin{array}{l}29 \\
11\end{array}$ & $\begin{array}{l}44 \\
28\end{array}$ & $\begin{array}{l}89 \\
86\end{array}$ & $\begin{array}{l}0.05 \\
0.03\end{array}$ & $1 .-667$ & 5.36 & 0.063 & 0.20 \\
\hline & $T$ & $\begin{array}{l}U \\
300\end{array}$ & $\begin{array}{r}8.8 \\
18.9\end{array}$ & $\begin{array}{l}14.9 \\
20.3 .\end{array}$ & $\underset{0}{11.5}$ & $\begin{array}{l}26 \\
15\end{array}$ & $\begin{array}{l}89 \\
92\end{array}$ & 0.07 & $1 . i 48$ & $3 .-\overline{69}$ & 0.362 & $\overline{1.16}$ \\
\hline \multirow[t]{2}{*}{$2 \mathrm{BU}-2$} & L & ${ }_{300}^{U}$ & $\begin{array}{l}17.4 \\
30.0\end{array}$ & $\begin{array}{l}30.3 \\
36.1\end{array}$ & $\begin{array}{r}21 \\
4\end{array}$ & $\begin{array}{l}42 \\
27\end{array}$ & $\begin{array}{l}71 \\
65\end{array}$ & $\begin{array}{l}0.10 \\
0.20\end{array}$ & 0.724 & $2 .-\overline{33}$ & 0.191 & $\ddot{0.62}$ \\
\hline & $\mathrm{T}$ & $\begin{array}{l}U \\
300\end{array}$ & $\begin{array}{l}27.6 \\
36.8\end{array}$ & $\begin{array}{l}32.1 \\
36.8\end{array}$ & $\begin{array}{r}16 \\
0\end{array}$ & $\begin{array}{l}30 \\
20\end{array}$ & $\begin{array}{l}71 \\
73\end{array}$ & $\begin{array}{l}0.07 \\
0.39\end{array}$ & 0.333 & 1.07 & 0.145 & 0.47 \\
\hline \multirow[t]{2}{*}{$\begin{array}{l}\mathrm{BT}, \\
\mathrm{Zr}-2: 5 \mathrm{Nb}\end{array}$} & L & $\begin{array}{l}4 \\
300\end{array}$ & $\begin{array}{l}28.3 \\
60.6\end{array}$ & $\begin{array}{l}42.2 \\
75.7\end{array}$ & $\begin{array}{r}19 \\
5\end{array}$ & $\begin{array}{l}33 \\
14\end{array}$ & $\begin{array}{l}68 \\
57\end{array}$ & $\begin{array}{l}0.11 \\
0.39\end{array}$ & 1.141 & 3.67 & 0.794 & 2.55 \\
\hline & $T$ & $\bigcup_{300}^{U}$ & $\begin{array}{r}.33 .6 \\
72.2\end{array}$ & $\begin{array}{l}40.0 \\
75.4\end{array}$ & $\begin{array}{l}5.5 \\
3\end{array}$ & $\begin{array}{r}17 \\
9\end{array}$ & $\begin{array}{l}69 \\
59\end{array}$ & $\begin{array}{l}0.16 \\
0.19\end{array}$ & 1.149 & 3.69 & 0.885 & $2 .-85$ \\
\hline
\end{tabular}

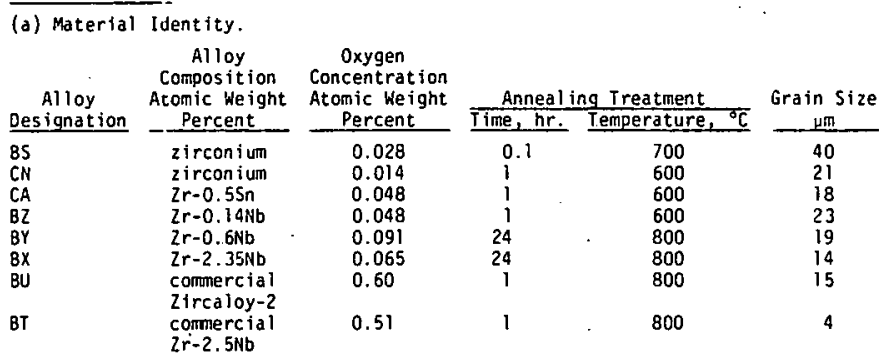

(b) $U$ = Unirradiated

(c) $f(Y S)=\Delta Y S / Y S$ where $Y S=0.2 \%$ of fset yield strength and $\Delta Y S=d i f f$ urence in yield strength for the irradiated and non-irradiated condition only.

(d) $f(U T S)=$ UUTS/UTS where UTS = ultimate strength and oUTS = difference in ultimate strength

for the irradiated and non-irradiated condition only. 
Table 15a. THE HEAT TREATMENT, HARDNESS AND TENSILE PROPERTIES OF ZIRCONIUM ALLOYS

\section{TESTED FOR CREEP IN-REACTOR (From Reference 31)}

\begin{tabular}{|c|c|c|c|c|c|c|c|c|c|c|c|c|c|}
\hline \multirow[b]{3}{*}{$\begin{array}{l}\text { Material } \\
\text { (code no.) }\end{array}$} & \multirow[b]{3}{*}{ Material } & & \multirow{3}{*}{$\begin{array}{l}\text { Hardness } \\
\text { on } \\
\text { Transv: } \\
\text { Section } \\
\text { (VHN) } \\
\end{array}$} & \multicolumn{8}{|c|}{ Tensile Properties (Longitudinal Sections) } & \multirow[b]{3}{*}{$\begin{array}{c}\text { In-Reac tor } \\
\text { Creep Test } \\
\quad \text { No. } \\
\end{array}$} & \multirow[b]{3}{*}{$\begin{array}{c}\text { Average } \\
\text { Grain } \\
\text { Size } \\
\mathrm{m} \\
\end{array}$} \\
\hline & & & & \multicolumn{4}{|c|}{ Roam Tempera ture } & \multicolumn{4}{|c|}{$300^{\circ} \mathrm{C}$} & & \\
\hline & & Heat Treatment & & $\begin{array}{l}0.2 \% \\
\text { Y.S. } \\
\text { ksi } \\
\end{array}$ & $\begin{array}{l}\text { UTS } \\
\underline{k s i}\end{array}$ & $\begin{array}{l}\text { Total* } \\
\text { Eln. } \\
\% \text { : } \\
\end{array}$ & $\begin{array}{l}\text { R.A. } \\
\stackrel{\%}{6}\end{array}$ & $\begin{array}{l}0.2 \% \\
\text { Y.S. } \\
\text { ksi } \\
\end{array}$ & $\begin{array}{l}\text { UTS } \\
\text { ksi } \\
\end{array}$ & $\begin{array}{l}\text { Total } \\
\text { Eln. } \\
\& \\
\end{array}$ & $\begin{array}{l}\text { R.A. } \\
\dot{q} \\
\end{array}$ & & \\
\hline 9 & $\begin{array}{l}\text { Zircaloy-2 } \\
\text { Rod }\end{array}$ & $\begin{array}{l}20 \% \text { cold-worked } \\
\text { stress-relieved } \\
72 \mathrm{~h} \text { at } 400^{\circ} \mathrm{C}\end{array}$ & 230 & 71.0 & 87.3 & 12 & 30 & 51.0 & 53.0 & 7 & 58 & $\mathrm{R}-2$ & 7 \\
\hline 1 & $\begin{array}{l}\text { Zircaloy-2 } \\
\text { Tube }\end{array}$ & $\begin{array}{l}19 \% \text { cold-worked, } \\
\text { autoc laved } 72 \mathrm{~h} \\
\text { at } 400^{\circ} \mathrm{C}\end{array}$ & 191 & 67.0 & 87.0 & 19 & & 46.9 & 56.0 & 20 & & $R-8, R-9$ & 7 \\
\hline 18 & $\begin{array}{l}\text { Zircaloy-2 } \\
\text { Rod }\end{array}$ & $\begin{array}{l}20 \% \text { cold-worked, } \\
\text { stress-relieved } \\
72 \text { h.at } 400^{\circ} \mathrm{C}\end{array}$ & 227 & 89.0 & 99.0 & 18 & 39 & 45.3 & 50.0 & 20 & 47. & $R-4, R x-20$ & 8 \\
\hline 25 & $\begin{array}{l}\text { Zircaloy-2 } \\
\text { Tube }\end{array}$ & $\begin{array}{l}16 \% \text { cold-worked, } \\
\text { autoclaved } 72 \mathrm{~h} \\
\text { at } 400^{\circ} \mathrm{C}\end{array}$ & 193 & 71.0 & 86.0 & 13 & 34. & 44.9 & 51.0 & 12 & 45 & $\begin{array}{l}R-6, R x-14, \\
R x-21\end{array}$ & 7 \\
\hline 27 & $\begin{array}{l}2 r-2.5 \text { wt } \% \\
\text { Nb Rod }\end{array}$ & $\begin{array}{l}\text { Water quenched } \\
\text { from } 850^{\circ} \mathrm{C} \text { aged } \\
24 \mathrm{~h} \text { at } 500^{\circ} \mathrm{C}\end{array}$ & 268 & 108.9 & 120.0 & 14 & 60 & 82.0 & 93.0 & 15 & 80 & $\begin{array}{l}R-7, R u-6, \\
R u-7\end{array}$ & \\
\hline 33 & $\begin{array}{l}\text { Zirconium } \\
\text { Rod }\end{array}$ & Annealed & 66 & 18.0 & 28.0 & 50 & 72 & 11.9 & 20.5 & 36 & 92 & $R x-19$ & 98 \\
\hline 34 & $\begin{array}{l}\mathrm{Zr}-2.5 \text { wt } \% \\
\text { Nb Tube }\end{array}$ & $\begin{array}{l}21 \% \text { cold-worked, } \\
\text { autoclaved } 72 \mathrm{~h} \\
\text { at } 400^{\circ} \mathrm{C}\end{array}$ & 214 & 77.9 & 110.9 & 14 & 44 & 53.0 & 73.9 & 14 & 56 & $\begin{array}{l}R-11 ; R-12 \\
R x-17\end{array}$ & \\
\hline 36 & $\begin{array}{l}\mathrm{Zr}-2.5 \text { wt } \% \\
\text { Nb Rod }\end{array}$ & $\begin{array}{l}\text { Water quenched } \\
\text { from } 875^{\circ} \mathrm{C} \text {, cold- } \\
\text { drawn } 30 \% \text { aged } 24 \\
24 \mathrm{~h} \text { at } 500^{\circ} \mathrm{C}\end{array}$ & 247 & 86.0 & 117.0 & 19 & 53 & 67.0 & 75.9 & 19 & 68 & $R x-13, R u-1$ & \\
\hline 37 & $\begin{array}{l}\text { Zr- } 2.5 \text { wt } \% \\
\text { Nb Tube }\end{array}$ & $\begin{array}{l}\text { Water quenched } \\
\text { from } 880^{\circ} \mathrm{C} \text { cold- } \\
\text { drawn } 22 \% \text { aged } \\
24 \mathrm{~h} \text { at } 500^{\circ} \mathrm{C}\end{array}$ & 252 & 136.0 & 105.9 & 23 & 54 & $\begin{array}{c}58.0 \\
.\end{array}$ & 74.9 & 20 & 61 & $R x-16$ & \\
\hline 39 & $\begin{array}{l}2 r-2.5 \text { wt } \% \\
\text { Nb Tube }\end{array}$ & $\begin{array}{l}\text { Water quenched } \\
\text { fram } 880^{\circ} \mathrm{C} \text {, cold- } \\
\text { drawn } 5 \% \text {, aged } \\
24 \mathrm{~h} \text { at } 500^{\circ} \mathrm{C}\end{array}$ & 255 & 96.0 & 115.0 & 19 & 52 & 60.0 & 82.0 & 19 & 62 & $R x-18$ & \\
\hline 42 & $\begin{array}{l}\text { Zricaloy-2 } \\
\text { Tube }\end{array}$ & $\begin{array}{l}19 \% \text { cold-worked, } \\
\text { autoc laved } 72 \mathrm{~h} \\
\text { at } 400^{\circ} \mathrm{C}\end{array}$ & 205 & 81.0 & 87.3 & 14 & 36 & 45.9 & 56.0 & 17 & & $R x-15$ & 8 \\
\hline 50 & $\begin{array}{l}2 r-2.5 \text { wt } \% \\
\text { Nb Tube }\end{array}$ & $\begin{array}{l}\text { Water quenched } \\
\text { from } 870^{\circ} \mathrm{C} \text { cold- } \\
\text { drawn } 16 \% \text { aged } \\
24 \text { h at } 500^{\circ} \mathrm{C}\end{array}$ & 262 & 97.0 & 122.0 & 20 & 51 & 73.9 & 88.0 & 17 & 65 & $R x-22$ & \\
\hline 51 & $\begin{array}{l}2 r-2.5 \text { wt } \% \\
\text { Nb Tube }\end{array}$ & $\begin{array}{l}\text { Water quenched } \\
\text { from } 870^{\circ} \mathrm{C} \text {, cold- } \\
\text { drawn } 5 \% \text {, aged } \\
24 \mathrm{~h} \text { at } 500^{\circ} \mathrm{C}\end{array}$ & 261 & 98.0 & 120.0 & 18 & 55 & 72.0 & 84.0 & 17 & 53 & $R x-24$ & \\
\hline 52 & $\begin{array}{l}\mathrm{Zr}-2.5 \mathrm{wt} \% \\
\mathrm{Nb} \text { tube }\end{array}$ & $\begin{array}{l}\text { Water quenched } \\
\text { from } 870^{\circ} \mathrm{C} \text {, cold- } \\
\text { drawn } 11 \% \text { aged } \\
24 \text { h at } 500^{\circ} \mathrm{C}\end{array}$ & 274 & 97.0 & 121.0 & 18 & 47 & 76.9 & 88.0 & 18 & 51 & $R x-23, R u-5$ & \\
\hline
\end{tabular}

$\star 2.5 \mathrm{~cm}$ gauge length. 
Table 15b. UNIAXIAL IN-REACTOR CREEP DATA AT $300^{\circ} \mathrm{C}$

(From Reference 31)

\begin{tabular}{|c|c|c|c|c|c|c|c|c|c|}
\hline $\begin{array}{l}\text { Test } \\
\text { No. }\end{array}$ & Material & $\begin{array}{l}\text { Direction } \\
\text { of Testing }\end{array}$ & $\begin{array}{l}\text { Stress } \\
\text { ksi }\end{array}$ & $\begin{array}{l}\text { Flux } \\
\text { E13 } \mathrm{n} /=\mathrm{m}^{2}-\mathrm{sec}\end{array}$ & $\begin{array}{c}\text { Duration } \\
\mathrm{hr}\end{array}$ & $\begin{array}{l}\text { Creep Rate } \\
\text { Near End } \\
\text { of Test } \\
\text { E7 hr-1 } \\
\end{array}$ & Comments & & $\begin{array}{c}\text { Creep Rate of Un- } \\
\text { irradiated Test } \\
\text { After Same Time } \\
\text { as In-Reactor Test } \\
\text { E7-hr-1 } \\
\end{array}$ \\
\hline & & & & & & $\mathrm{hr}^{-1} \times 10^{7}$ & . & & \\
\hline$R-6$ & Zircaloy-2, tube 84 stress & $\mathrm{L}$ & 20 & 0.6 & 5700 & $\star 3.5 \pm 10 \%$ & Rx-14 specimen preirradiated & & 0.2 \\
\hline$R \times-14$ & relieved $72 \mathrm{~h}$ at $400^{\circ} \mathrm{C}$ & L & 20 & 0.7 & 2000 & $\star 3.0 \pm 30 \%$ & to $3 \times 10^{20} \mathrm{n} / \mathrm{cm}^{2}$ & & 0.8 \\
\hline$R x-48$ & (material l, Table 1) & $\mathrm{T}$ & 20 & 0.6 & $1800^{(a)}$ & $1.5 \pm 50 \%$ & $\begin{array}{l}\text { at } 300^{\circ} \mathrm{C} \text {. Its out-of-flux } \\
\text { creep rate after } 2000 \mathrm{~h} \\
=0.4 \times 10^{-7} \mathrm{~h}^{-1}\end{array}$ & & 1.0 \\
\hline$R x-40$ & & L & 40 & 0.8 & 4000 & $\star 4.7 \pm 10 \%$ & & & \\
\hline$R u-20$ & & L & 40 & 2.0 & 1300 & $* 14.0 \pm 15 \%$ & . & $\therefore$ & 4.0 \\
\hline$R x-44$ & . & L & 65 & 0.7 & 640 & $12.0 \pm 10 \%$ & $\begin{array}{l}\text { Specimen ruptured because } \\
\text { of accidental overload. }\end{array}$ & & 20 \\
\hline Ru- 25 & $\begin{array}{c}2 r-2.5 \text { wt } \% \mathrm{Nb} \text {, tube } 603 \text {, } \\
\text { stress relieved } 3 \mathrm{~h} \text { at }\end{array}$ & L & 65 & 2.8 & $2900^{(a)}$ & $\star 45.0 \pm 15 \%$ & $\begin{array}{l}\text { Specimen stress relieved } \\
24 \mathrm{~h} \text { at } 400^{\circ} \mathrm{C}\end{array}$ & & $\begin{array}{r}130 \\
75\end{array}$ \\
\hline $\begin{array}{l}R x-41 \\
\text { part } 1\end{array}$ & $\begin{array}{l}400^{\circ} \mathrm{C} \text { (material } 3 \\
\text { Table 1) }\end{array}$ & T & 40 & 1.0 & 3600 & $\star 2.7 \pm 20 \%$ & $\begin{array}{l}\text { Estimated creep rate in } \\
\quad R \times-40 \mathrm{f} 1 \mathrm{ux}- \\
2.15 \times 10^{-7} \mathrm{~h}^{-1}\end{array}$ & & 1.5 \\
\hline $\begin{array}{l}\text { Rx-41, } \\
\text { part it }\end{array}$ & & T & 65 & 0.9 & $\begin{array}{l}2300(a) \\
(\text { tota }) \\
5900)\end{array}$ & $\star 9.0 \pm 10 \%$ & $\begin{array}{l}\text { Estimated creep rate } \\
\text { in } R \times-44 \text { flux - } \\
7.0 \times 10^{-7} h^{-1}\end{array}$ & & 13 \\
\hline$R x-42$ & & $\mathrm{~T}$ & 65 & 1.1 & 1600 & $\star 5.0 \pm 20 \%$ & $\begin{array}{l}\text { Estimated creep rate } \\
\text { in } 8 \times-44 \text { flux } \\
3.2 \times 10^{-7} h^{-1}\end{array}$ & & 19 \\
\hline$R-11$ & $2 r-2.5$ wt $\%$ ND, tube 411 & L & 23 & 0.7 & 3200 & $\star 2.0 \pm 15 \%$ & & & 0.4 \\
\hline$R-12$ & $\begin{array}{l}\text { stress relieved } 72 \mathrm{~h} \text { at } \\
400^{\circ} \mathrm{C} \text { (material } 2, \\
\text { Table I }\end{array}$ & L & 16.5 & 0.6 & 2800 & $\star 0.7 \pm 10 \%$ & & & 0.3 \\
\hline$R x-17$ & As above, tube 412 & L & 20 & 0.7 & 2100 & $1.0 \pm 40 \%$ & & & 1.5 \\
\hline$R \times-43$ & & L & 20 & 0.8 & 550 & $8.5 \pm 10 \%$ & & & 3.0 \\
\hline$R u-15$ & Zircaloy-2 slab, as received & $\mathrm{L}$ & 20 & 2.6 & 3600 & $\star 10.0 \pm 10 \%$ & & & 0.4 \\
\hline Ru- 14 & (material 5, Table I) & $S-T$ & 20 & 2.5 & 1950 & $\star 8.0 \pm 20 \%$ & $\begin{array}{l}\text { Test was at } 316^{\circ} \mathrm{C} \text {; estimated } \\
\text { creep rate at } 300^{\circ} \mathrm{C} \text { - } \\
6 \times 10^{-7} \mathrm{~h}^{-1}\end{array}$ & & 2.0 \\
\hline $\mathrm{Ru}-17$ & & S-T & 20 & 2.3 & 4300 & $\star 5.5 \pm 30 \%$ & & & 0.6 \\
\hline
\end{tabular}

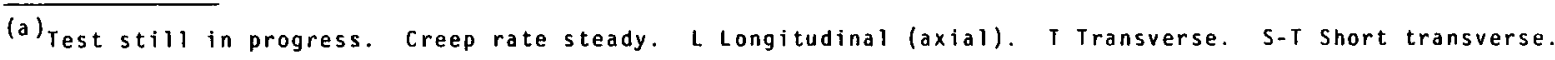


Table 15c. IN-REACTOR CREEP TESTS ON ZIRCALOY-2

(From Reference 31)

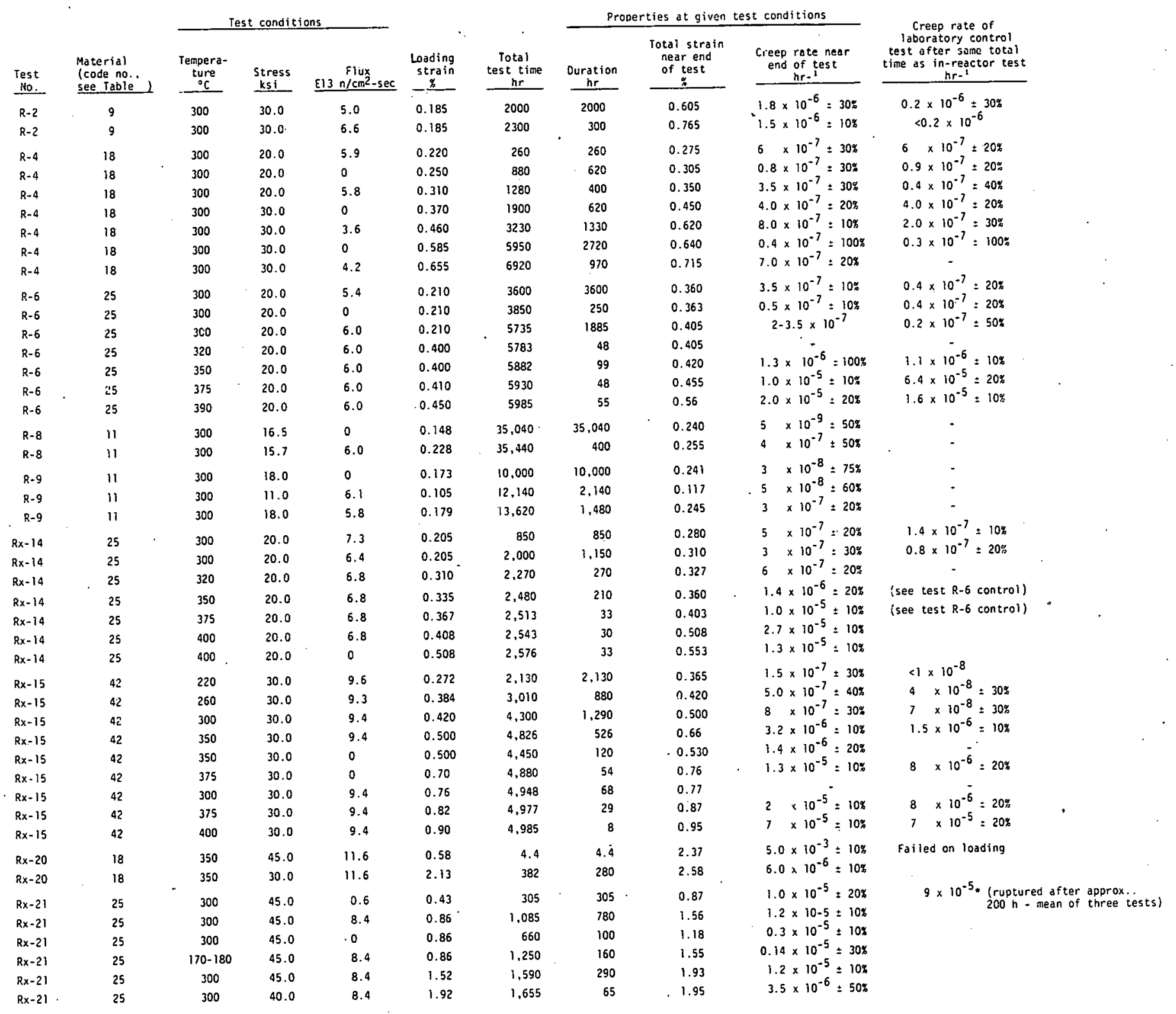


Table 15d. IN-REACTOR CREEP OF Zr-2.5 WT\% Nb ALLOYS

(From Reference 31)

\begin{tabular}{|c|c|c|c|c|c|c|}
\hline \multirow[b]{2}{*}{$\begin{array}{l}\text { Test } \\
\text { No.. }\end{array}$} & \multirow[b]{2}{*}{$\begin{array}{l}\text { Material } \\
\text { Code No } \\
\text { (See Tabie) }\end{array}$} & \multicolumn{3}{|c|}{ Test Conditions } & \multirow[b]{2}{*}{$\begin{array}{l}\text { Loading } \\
\text { Strain } \\
\end{array}$} & \multirow[b]{2}{*}{$\begin{array}{c}\text { Total } \\
\text { Test }{ }^{T} \text { ime } \\
\text { hr }\end{array}$} \\
\hline & & Tempera ture & $\begin{array}{l}\text { Stress } \\
\mathrm{ksi}\end{array}$ & $\begin{array}{ll}\text { Flux } \\
\mathrm{E} / 2 \mathrm{n} / \mathrm{Cm}^{2}-\mathrm{sec} \\
\end{array}$ & & \\
\hline$R-7$ & 27 & 300 & 30.0 & 6.2 & 0.240 & 835 \\
\hline$R=7$ & 27 & 300 & 30.0 & 6.2 & 0.275 & 2650 \\
\hline$R-11$ & 34 & 300 & 23.0 & 7.0 & 0.254 & 3200 \\
\hline$R-12$ & 34 & 300 & 16.5 & 5.6 & 0.102 & 2800 \\
\hline$R x-13$ & 36 & 300 & 23.0 & 5.7 & 0.226 & 2569 \\
\hline$R x-13$ & 36 & 350 & 23.0 & 5.7 & 0.424 & 2612 \\
\hline$R x-13$ & 36 & 400 & 23.0 & 5.7 & 0.450 & 2629 \\
\hline$R x-16$ & 37 & 300 & 23.0 & 5.7 & 0.288 & 295 \\
\hline$R x-16$ & 37 & 300 & 36.5 & 5.7 & 0.375 & 1750 \\
\hline $8 x-16$ & 37 & 300 & 45.0 & 5.7 & 0.558 & 2980 \\
\hline$R x-16$ & 37. & 320 & 45.0 & 5.7 & 0.628 & 3130 \\
\hline$R_{x}-16$ & 37 & 300 & 16.0 & 5.7 & 0.388 & 5540 \\
\hline$R x-17$ & 34 & 300 & 20.0 & 6.8 & 0.249 & $\dot{2} 125$ \\
\hline$R x=18$ & 39 & 300 & 16.0 & $5: 3$ & 0.232 & 2100 \\
\hline$R x-22$ & 50 & 300 & 16.0 & 5.8 & 0.184 & 4900 \\
\hline$R x-23$ & 52 & 260 & 20.0 & 5.3 & 0.195 & 5300 \\
\hline$R x-23$ & 52 & 300 & 20.0 & 5.3 & 0.27 & 6250 \\
\hline$R x-23$ & 52 & 350 & 20.0 & 5.3 & 0.31 & 6620 \\
\hline$R x-24$ & 51 & 300 & 60.0 & 8.9 & 0.568 & 930 \\
\hline$R_{u-1}$ & 36 & 300 & 23.0 & 24 & 0.218 & 2560 \\
\hline Ru - 5 & 52 & 300 & 16.0 & 22 & 0.266 & 1120 \\
\hline$R u-6$ & 27 & 300 & 16.0 & 24 & 0.182 & 1400 \\
\hline Ru-7 & 27 & 300 & 16.0 & 21 & 0.210 & 3140 \\
\hline
\end{tabular}

\begin{tabular}{|c|c|c|c|}
\hline $\begin{array}{l}\text { Duration } \\
\text { hr }\end{array}$ & $\begin{array}{l}\text { Total Strain } \\
\text { Near End of } \\
\text { Test } q \\
\end{array}$ & $\begin{array}{l}\text { Creep Rate } \\
\text { Near End } \\
\text { Iest hir- } \\
\end{array}$ & $\begin{array}{l}\text { Creep Rate of Laboratory } \\
\text { Control Iest After Same } \\
\text { Total Time as Iq-reactor } \\
\text { Test hr-l } \\
\end{array}$ \\
\hline 835 & 0.293 & $1.0 \times 10^{-7}=30 \%$ & $1.7 \times 10^{-7}$ \\
\hline 1210 & 0.301 & $0.8 \times 10^{-7} \pm 308$ & $2.0 \times 10^{-7}$ \\
\hline 3200 & $0.355^{\circ}$ & $2.0 \times 10^{-7} \pm 15 \%$ & $4.0 \times 10^{-8}$ \\
\hline 2800 & 0.157 & $7.0 \times 10^{-8} \pm 10 \%$ & $5.0 \times 10^{-8}$ \\
\hline 2569 & 0.420 & $2.0 \times 10^{-7} \pm 15 \%$ & $3.5 \times 10^{-7}$ \\
\hline 43 & 0.439 & $1.5 \times 10^{-6} \pm 10 \%$ & $7.0 \times 10^{-6}$ \\
\hline 17 & 0.520 & $4.3 \times 10^{-5} \pm 10 \%$ & $1.3 \times 10^{-4}$ \\
\hline 295 & - & - & - \\
\hline 1455 & 0.478 & $1.5 \times 10^{-7} \pm 30 \%$ & $6.0 \times 10^{-7}$ \\
\hline 1230 & 0.628 & $2.0 \times 10^{-7} \pm 30 \%$ & $6.0 \times 10^{-7}$ \\
\hline 150 & 0.635 & -- & - \\
\hline 2410 & 0.358 & $9.5 \times 10^{-8} \pm 30 x$ & $7.0 \times 10^{-8}$ \\
\hline 2125 & 0.340 & $1.05 \times 10^{-7}+40 \%$ & $1.5 \times 10^{-7}$ \\
\hline 2100 & 0.295 & $0.80 \times 10^{-7} 140 \%$ & $0.9 \times 10^{-7}$ \\
\hline 4900 & 0.308 & $9.0 \times 10^{-8} \pm 20 \%$ & $41 \times 10^{-8}$ \\
\hline 5300 & 0.27 & $1.05 \times 10^{-7} \pm 158$ & $2 \times 10^{-8}$ \\
\hline 950 & 0.30 & $4 \times 10^{-7} \pm 20 \%$ & $7 \times 10^{-8}$ \\
\hline 370 & 0.35 & $1.3 \times 10^{-6} \div 20 \%$ & $1.4 \times 10^{-6}$ \\
\hline 930 & 0.755 & $8.0 \times 10^{-7} \pm 15 \%$ & $2 \times 10^{-6}$ \\
\hline 2560 & 0.648 & $1.4 \times 10^{-6} \pm 20 \%$ & $1: 3 \times 10^{-7}$ \\
\hline 1120 & 0.420 & $1.15 \times 10^{-6} \pm 15 \%$ & $7.0 \times 10^{-8}$ \\
\hline 1400 & 1.260 & $8.0 \times 10^{-7} \pm 50 \%$ & $0.5 \times 10^{-7}$ \\
\hline 3140 & 0.440 & $1.8 \times 10^{-7}=50 \%$ & $40.5 \times 10^{-7}$ \\
\hline
\end{tabular}


Table 16. IN-REACTOR CREEP TESTS OF ANNEALED ZIRCONIUM

(From Reference 31)

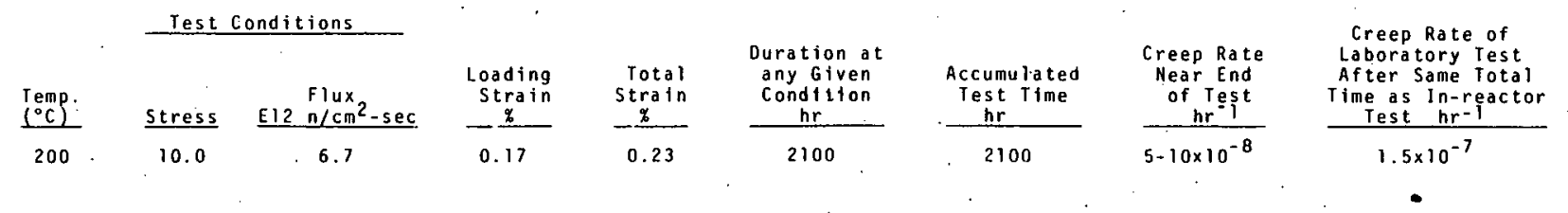

20

20.0

20.0

20.0

15.0

15.0

15.0

15.0

10.0
.6 .1

0
(during

shutdown)

$\begin{array}{ccc}6.1 & 0.80 & 0.98 \\ 6.1 & 0.92 & 0.96 \\ \begin{array}{c}\text { (during } \\ \text { shutdoisn) }\end{array} & & 0.93 \\ 1 & 0.97 & 1.02 \\ 6.1 & & 1.14 \\ 6.1 & 1.105 & 1.12\end{array}$

$0.78 . \quad 1500$

$0.77 \quad 100$

100

300

300 .

150

35 .

25

60
$3 \times 10^{-7}$

3400

4250

4100

4275

4.300

4360
$4.0 \times 10^{-7}$

$4-5 \times 10^{-7}$

$$
\begin{aligned}
& 4 \times 10^{-6} \\
& 1.6 \times 10^{-6} \\
& 1.6 \times 10^{-6} \\
& 2.2 \times 10^{-5} \\
& 2.2 \times 10^{-5} \\
& 2.7 \times 10^{-6}
\end{aligned}
$$

Large scatter of test data beyond

$1700 \mathrm{~h}$. Machine removed from reactor for repairs and returned for test at higher stress and temperature on the same specimen

Suffered large temperature cycles in the early part of $220^{\circ} \mathrm{C}$ test

$6 \times 10^{-5}$
$1.4 \times 10^{-6}$
.
$\cdots$
$\cdots$

Creep rate steady

Creep rate steady 
Table 17a. FATIGUE CRACK PROPAGATION DATA FOR IRRADIATED AND UNIRRADIATED ZIRCALOY -2 TUBING AT $20^{\circ} \mathrm{C}$

(From References 52, $53 \& 54$ )

\begin{tabular}{|c|c|c|c|c|c|c|}
\hline \multirow[b]{2}{*}{$\begin{array}{l}\text { Material } \\
\text { Condition }\end{array}$} & \multicolumn{4}{|c|}{$\begin{aligned} \text { Ult timate Strengths } 020^{\circ} \mathrm{C} & =110 \mathrm{ksi} \text { unirradiated } \\
& =130 \mathrm{ksi} \text { irradiated }\end{aligned}$} & \multirow[b]{2}{*}{$\frac{\mathrm{a}}{\sqrt{\mathrm{Rt}}}$} & \multirow[b]{2}{*}{ ksi $\sqrt[k]{k_{i n}}$} \\
\hline & $\begin{array}{l}\text { Fluence } \\
\mathrm{E} 20 \mathrm{n} / \mathrm{cm}^{2} \\
\end{array}$ & $\begin{array}{l}\text { Failure } \\
\text { Stress } \\
\text { ksi } \\
\end{array}$ & $\begin{array}{l}\text { Critical Crack } \\
\text { Length (2a) } \\
\text { inches } \\
\end{array}$ & $\underline{R / t}$ & & \\
\hline \multirow[t]{6}{*}{ CW $\sim 45 \%$ R.A. } & - & 38.0 & 1.0 & 10 & 0.98 & 67.7 \\
\hline & - & 28.0 & 1.5 & 10 & 1.47 & 67.5 \\
\hline & - & 18.0 & 2.0 & 10 & 1.97 & 56.4 \\
\hline & - & 15.0 & 2.5 & 10 & 2.46 & 61.0 \\
\hline & v1-4 & 22.0 & 1.0 & 10 & 0.98 & 35.3 \\
\hline & $\sim 7-4$ & 20.0 & 1.12 & 10 & 1.10 & 35.1 \\
\hline \multirow{6}{*}{$\begin{array}{l}\text { CW } \sim 45 \% \text { R.A. } \\
\sim 300 \mathrm{ppm} \mathrm{H}\end{array}$} & - & 20.0 & 1.0 & 10 & 0.98 & 36.6 . \\
\hline & - & 14.0 & 1.1 & 10 & 1.08 & 27.6 \\
\hline & - & 12.0 & 1.2 & 10 & 1.18 & 30.1 \\
\hline & - & 14.0 & 1.25 & 10 & 1.23 & 31.7 \\
\hline & - & 15.0 & 1.3 & 10 & 1.28 & 35.6 \\
\hline & - & 12.0 & 1.3 & 10 & 1.28 & 28.2 \\
\hline \multirow[t]{3}{*}{ CW $230 \%$ R.A. } & - & 30.0 & 1.5 & 5 & 1.17 & 59.1 \\
\hline & - & 20.0 & 1.8 & 5 & 1.41 & 60.6 \\
\hline & - & 19.0 & 2.25 & 5 & 1.76 & 72.5 \\
\hline \multirow{3}{*}{$\begin{array}{l}\mathrm{CW} \sim 30 \% \text { R.A. } \\
\sim 300 \mathrm{ppm} \mathrm{H}\end{array}$} & - & 21.0 & 1.25 & 5 & 0.98 & 39.9 \\
\hline & - & 19.0 & 1.12 & 5 & 0.88 & 31.8 \\
\hline & - & 17.0 & 1.4 & 5 & 1.10 & 33.9 \\
\hline \multirow[t]{4}{*}{ CW $330 \%$ R.A. } & 9.5 & 27.0 & 0.97 & 5 & 0.76 & 39.9 \\
\hline & 10.2 & 22.0 & 1.07 & 5 & 0.84 & 34.4 \\
\hline & 12.0 & 38.0 & 0.6 & 5 & 0.47 & 43.3 \\
\hline & 19.0 & 22.0 & 1.0 & 5 & 0.78 & 32.6 \\
\hline
\end{tabular}




\section{Table 17b. EFFECT OF IRRADIATION ON THE FRACTURE TOUGHNESS OF IRRADIATED ZIRCALOY -4 (From Reference 54)}

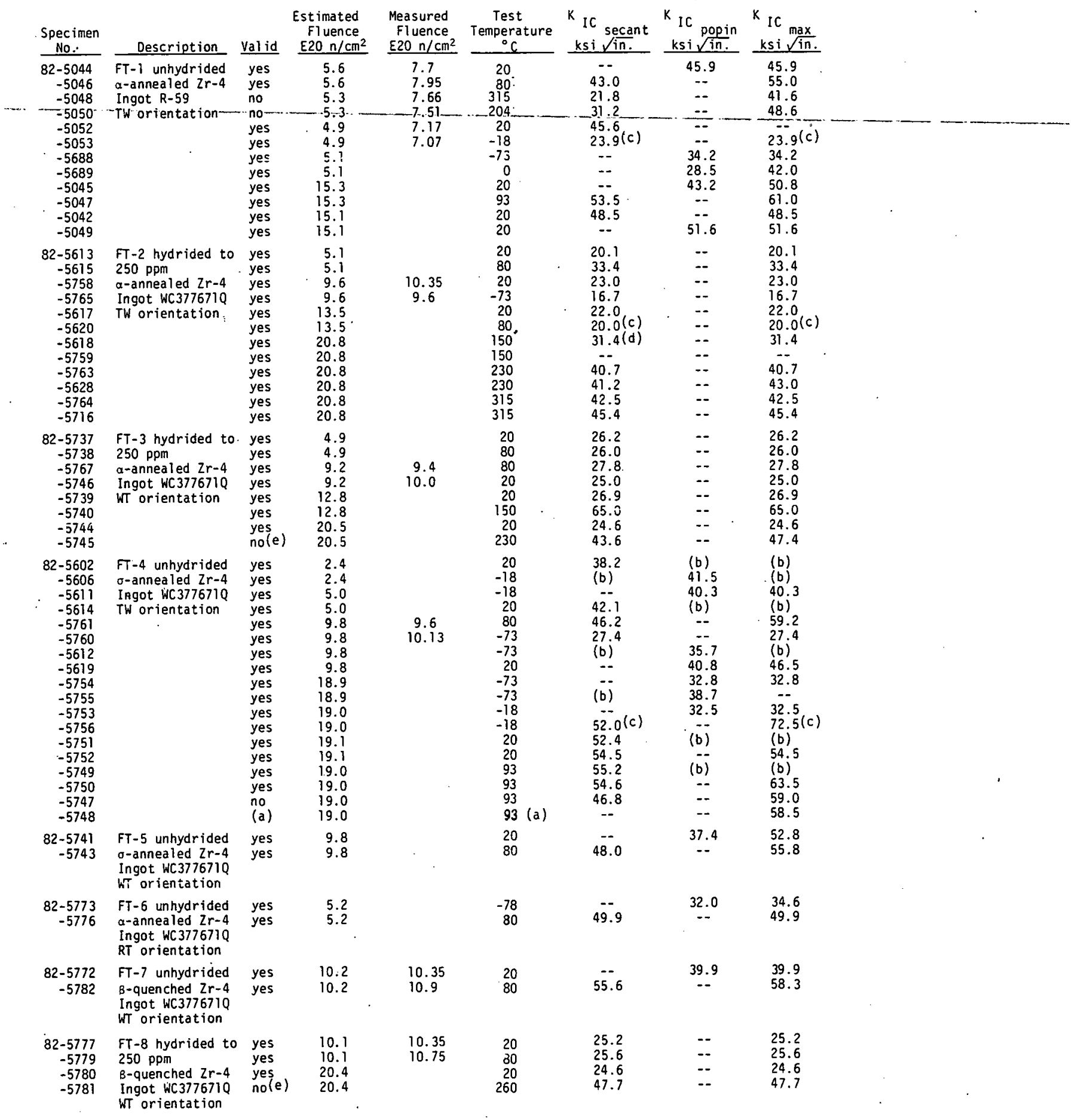

(a) Validity impossible to determine due to strain gage failure.

(b) Specimens unloaded rapidly after $K$ iC secant or $K$ iC popin for sectioning to allow for plastic zone size determination.

(c) Validity highly questionable due to excessively long fatigue crack.

(d) Specimen improperly loaded.

(e) Thickness required for ASTM valid test 20.6 in. 
Table. 18. MILLED SLOT FRACTURE DATA FOR IRRADIATED AND UNIRRADIATED $17 \%$ - 23\% COLD WORKED ZIRCALOY-2 TUBING

(From Reference 52, 55)

\begin{tabular}{|c|c|c|c|c|c|c|}
\hline $\begin{array}{c}\text { Test } \\
\text { Temperature } \\
{ }^{\circ} \mathrm{C} \\
\end{array}$ & $\begin{array}{c}\begin{array}{c}\text { Tluence } \\
\mathrm{n} / \mathrm{cm}^{2}\end{array} \\
\end{array}$ & $\begin{array}{l}\text { Failure } \\
\text { Stress } \\
\text { ksi } \\
\end{array}$ & $\begin{array}{c}\text { Critical } \\
\text { Crack Length } \\
2 a-i n . \\
\end{array}$ & $R / t$ & $\frac{a}{\sqrt{R T}}$ & $\begin{array}{c}k_{c}(1) \\
\text { ksi } \sqrt{i n .}\end{array}$ \\
\hline 300 & $1.2 \times 10^{21}$ & 17.6 & 3 & 10 & 2.78 & 62.1 \\
\hline 20 & $1.2 \times 10^{21}$ & 28.6 & 2 & 10 & 1.85 & 106.8 \\
\hline 20 & $8.0 \times 10^{20}$ & 16.3 & 4 & 10 & 3.70 & 156.9 \\
\hline 20 & $1.2 \times 10^{21}$ & 17.2 & 3 & 10 & $2: 78$ & 110.4 \\
\hline 300 & $1.0 \times 10^{21}$ & 24.0 & 2.5 & 10 & 2.32 & 120.1 \\
\hline 20 & $8.0 \times 10^{20}$ & 21.3 & 2.5 & 10 & 2.32 & 106.6 \\
\hline 300 & $8.0 \times 10^{20}$ & 34.2 & 2 & 10 & 1.85 & 127.7 \\
\hline 300 & 0 & 24.8 & 2 & 10 & 1.85 & 92.6 \\
\hline 20 & . & 34.4 & 2 & 10 & 1.85 & 128.4 \\
\hline 300 & 0 & 19.0 & 3 & 10 & 2.78 & 121.9 \\
\hline 20 & 0 & 20.4 & 3 & 10 & 2.78 & 130.9 \\
\hline 300 & 0 & 21.1 & 2.5 & 10 & 2.32 & 105.6 \\
\hline 20 & 0 & 23.0 & $2.5^{-}$ & 10 & 2.32 & 115.1 \\
\hline 300 & 0 & 18.7 & 3. & 10 & 2.78 & 120.0 \\
\hline 300 & $7.0 \times 10^{20}$ & 16.0 & 3.5 & 11 & 3.24 & 127.4 \\
\hline 300 & $2.0 \times 10^{20}$ & 16.8 & 3 & 11 & 2.78 & 107.8 \\
\hline 300 & Out of flux & 15.0 & 3 & 11 & 2.78 & 96.3 \\
\hline 300 & $2.6 \times 10^{20}$ & 44.0 & 1.5 & 11 & 1.39 & 115.7 \\
\hline 300 & $2.6 \times 10^{20}$ & 21.9 & 3 & 11 & 2.78 & 140.5 \\
\hline 300 & $2.6 \times 10^{20}$ & 38.6 & 1.5 & 11 & 1.39 & 101.5 \\
\hline $300^{\circ}$ & $2.6 \times 10^{20}$ & 18.0 & 3 & 11 & 2.78 & 115.5 \\
\hline 300 & Out of flux & 39.2 & 1.5 & 11 & 1.39 & 103.1 \\
\hline 300 & Out of flux & 16.2 & 3 & 11 & 2.78 & 104.0 \\
\hline 300 & $1.6 \times 10^{20}$ & 25.2 & 2.25 & 14 & 1.98 & 69.1 \\
\hline
\end{tabular}

(1) Value uncorrected for plasticity effects where:

$$
c_{p}=\cos \sigma_{2}\left(\frac{\sigma_{\text {flawed }}}{\sigma_{\text {unflawed }}}\right) \text {. }
$$


Table 19. MILLED SLOT FRACTURE DATA FOR IRRADIATED AND

UNIRRADIATED 30\% COLD WORKED ZIRCALOY-2 TUBING (From Reference 52, 54)

\begin{tabular}{|c|c|c|c|c|c|}
\hline Sample & $\begin{array}{c}\text { Fluence } \\
\mathrm{n} / \mathrm{cm}^{2}\end{array}$ & $\begin{array}{c}\text { Slot Length } \\
\text { in. } \\
\end{array}$ & 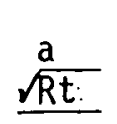 & $\begin{array}{l}\text { Ultimate Hoop } \\
\text { Stress - ksi }\end{array}$ & $\underline{\mathrm{ksi}^{\mathrm{K}_{\mathrm{c}}} \sqrt{\mathrm{in} .}}$ \\
\hline $1756-1$ & 0 & 0.81 & 6.64 & 83.5 & 103.3 \\
\hline $1756-2$ & 0 & 3.00 & 2.36 & 30.8 & 98.7 \\
\hline $1756-3$ & $0.82 \times 10^{21}$ & 0.81 & 0.64 . & 81.7 & 105.9 \\
\hline $1756-4$ & $0.82 \times 10^{21}$ & 3.00 & 2.36 & 28.6 & 91.6 \\
\hline $1756-5$ & 0 & 0.81 & 0.64 & 83.5 & 108.1 \\
\hline $1756-6$ & 0 & 3.00 & 2.36 & 29.7 & 95.1 \\
\hline $2455-1$ & $0.82 \times 10^{21}$ & 0.35 & 0.27 & 135.0 & 106.7 \\
\hline $2455-2$ & $1.10 \times 10^{21}$ & 3.00 & 2.36 & 35.7 & 114.4 \\
\hline $2455-3$ & $1.11 \times 10^{21}$ & 0.81 & 0.64 & 86.0 & 111.4 \\
\hline $2455-4$ & $1.01 \times 10^{21}$ & 1.50 & 1.18 & 65.0 & 125.8 \\
\hline $0758-1$ & $1.75 \times 10^{21}$ & 1.50 & 1.18 & 45.0 & 87.1 \\
\hline
\end{tabular}


Table 20. EFFECT OF IRRADIATION ON THE FATIGUE CRACK

PROPAGATION RATE OF ZIRCALOY-4

(From Reference 56)

\begin{tabular}{|c|c|c|c|c|c|}
\hline $\begin{array}{l}\text { Specimen } \\
\text { No. } \\
\end{array}$ & $\begin{array}{c}\text { Specimen } \\
\text { Description } \\
\end{array}$ & $\begin{array}{c}\text { Fluence } \\
\mathrm{E} 20 \mathrm{n} / \mathrm{cm}^{2} \\
\end{array}$ & $\begin{array}{c}\text { Test } \\
\text { Temperature } \\
{ }^{\circ} \mathrm{F} \\
\end{array}$ & $\begin{array}{l}K \text { ave } \\
k \text { sivin. }\end{array}$ & $\begin{array}{c}\Delta \mathrm{a} / \Delta \mathrm{n} \\
\mu \mathrm{in} . / \mathrm{cycle}\end{array}$ \\
\hline $\begin{array}{r}82-5052 \\
-5053 \\
-5047\end{array}$ & $\begin{array}{l}\text { FT-1 unhydrided } \\
\alpha \text {-annealed, R-59 } \\
\text { TW orientation }\end{array}$ & $\begin{array}{r}7.1 \\
7.0 \\
15.3\end{array}$ & $\begin{array}{l}R T \\
R T \\
R T\end{array}$ & $\begin{array}{l}20.8 \\
22.0 \\
16.4\end{array}$ & $\begin{array}{l}12.0 \\
13.0 \\
23.0\end{array}$ \\
\hline $\begin{array}{r}82-5758 \\
-5765 \\
-5613 \\
-5617 \\
-5620 \\
-5628 \\
-5716 \\
-5759\end{array}$ & $\begin{array}{l}\text { FT-2 hydrided } \\
\alpha-a n n e a l e d, 71 Q \\
\text { TW orientation }\end{array}$ & $\begin{array}{r}10.3 \\
9.6 \\
5.1 \\
13.5 \\
13.5 \\
20.8 \\
20.8 \\
20.8\end{array}$ & $\begin{array}{l}\text { RT } \\
\text { RT } \\
\text { RT } \\
\text { RT } \\
\text { RT } \\
\text { RT } \\
\text { RT } \\
\text { RT }\end{array}$ & $\begin{array}{l}13.0 \\
15.1 \\
17.1 \\
14.7 \\
17.5 \\
15.1 \\
20.9 \\
13.0\end{array}$ & $\begin{array}{r}6.2 \\
8.7 \\
16.7 \\
8.3 \\
16.7 \\
83.0 \\
78.0 \\
11.0\end{array}$ \\
\hline $\begin{array}{r}82-5767 \\
-5737\end{array}$ & $\begin{array}{l}\text { FT-3 hydrided } \\
\alpha \text {-annealed, } 710, \text { WT }\end{array}$ & $\begin{array}{l}9.2 \\
4.9\end{array}$ & $\begin{array}{l}\text { RT } \\
\text { RT }\end{array}$ & $\begin{array}{l}10.7 \\
13.3\end{array}$ & $\begin{array}{l}\text { none } \\
12.5\end{array}$ \\
\hline $\begin{array}{r}82-5611 \\
-5619 \\
-5761 \\
-5754 \\
-5753\end{array}$ & $\begin{array}{l}\text { FT-4 unhydrided } \\
\alpha-\text { anneal ed } \\
\text { Zr-4, 710, TW }\end{array}$ & $\begin{array}{r}5.0 \\
9.8 \\
9.8 \\
18.9 \\
19.0\end{array}$ & $\begin{array}{l}\text { RT } \\
\text { RT } \\
\text { RT } \\
\text { RT } \\
\text { RT }\end{array}$ & $\begin{array}{l}17.4 \\
18.4 \\
17.1 \\
13.6 \\
13.4\end{array}$ & $\begin{array}{r}5.0 \\
38.3 \\
60.0 \\
\text { none } \\
\text { none }\end{array}$ \\
\hline $\begin{array}{r}82-5741 \\
-5743\end{array}$ & $\begin{array}{l}\text { FT-5 unhydrided } \\
\alpha \text {-annealed, } 71 Q, \text { WT }\end{array}$ & $\begin{array}{l}9.8 \\
9.8\end{array}$ & $\begin{array}{l}\text { RT } \\
\text { RT }\end{array}$ & $\begin{array}{l}11.6 \\
14.4\end{array}$ & $\begin{array}{l}\text { none } \\
\text { none }\end{array}$ \\
\hline $82-5772$ & $\begin{array}{l}\text { FT-7 unhydrided } \\
\text { B-quenched, } 710, \text { TW }\end{array}$ & 1.0 .2 & RT & 15.5 & 5.3 \\
\hline $82-5779$ & $\begin{array}{l}\text { FT-8 hydrided } \\
\text { B-quenched, 71Q, TW }\end{array}$ & 10.1 & RT & 18.0 & 13.6 \\
\hline
\end{tabular}


Table 21. FATIGUE CRACK GROWTH AND PROPAGATION DATA FOR UNIRRADIATED $\mathrm{Zr}-2.5 \mathrm{WT} \% \mathrm{Nb}$ ALLOY TUBING AT $20^{\circ} \mathrm{C}$ (From Reference 57)

\begin{tabular}{|c|c|c|c|c|c|c|c|c|c|c|c|}
\hline $\begin{array}{l}\text { Material } \\
\text { Condition } \\
\end{array}$ & $\begin{array}{c}\text { Hominal } \\
\text { Peak Hoop } \\
\text { Stress } \\
\text { ksi } \\
\end{array}$ & $\begin{array}{r}\hat{1} 0 \\
\mathrm{ksi} \\
\end{array}$ & $\begin{array}{l}\text { Critical } \\
\text { Crack } \\
\text { Length } \\
\text { za }=\text { In. }\end{array}$ & $\begin{array}{l}\text { Cycles to } \\
\text { Initiate } \\
\text { Cracking } \\
\text { Cracking }\end{array}$ & $\begin{array}{r}\text { Cycles } \\
\text { to Leak } \\
\end{array}$ & $\begin{array}{r}\text { Leak } \\
\text { Crack } \\
\text { Length } \\
\text { in. } \\
\end{array}$ & $\begin{array}{l}\text { Cycles to } \\
\text { Failure }\end{array}$ & $\begin{array}{r}\text { Cycle } \\
\text { Rate } \\
\text { per hr } \\
\end{array}$ & $R / t$ & $\sqrt{\mathrm{Rt}}$ & $\begin{array}{c}k_{c} \\
k s i \sqrt{i n} .\end{array}$ \\
\hline Heat Treated & 23.0 & 21.5 & 1.37 & 25,300 & 9,695 & 0.43 & 18,628 & 400 & 7 & 1.60 & 35.8 \\
\hline \multirow{2}{*}{\multicolumn{12}{|c|}{ + Aged }} \\
\hline & & & & & & & & & & & \\
\hline & 23.0 & 21.5 & 1.31 & 210,000 & 17,400 & 0.42 & 24,960 & 400 & 7 & 1.53 & 35.7 \\
\hline & 23.0 & 21.5 & 1.08 & 215,000 & 28,400 & 0.41 & 35,554 & 400 & 7 & 1.26 & 31.9 \\
\hline & 23.0 & 21.5 & 0.95 & 222,000 & 40,550 & 0.41 & 47,199 & 400 & 7 & 1.11 & 29.6 \\
\hline & 23.0 & 21.5 & 1.05 & 294,000 & 114.900 & 0.38 & 121,550 & 400 & 6 & 1.16 & 31.2 \\
\hline & $20.0^{\circ}$ & 19.5 & 2.05 & -.. & 214,600 & $\begin{array}{c}0.12 \\
\left(\begin{array}{c}0.0 .11 \\
\text { in } \\
\text { in } \\
\text { face }\end{array}\right)\end{array}$ & 31.131 & 400 & 7 & 2.40 & 41.4 \\
\hline & 26.5 & 26.0 & 0.95 & 22,000 & 23,000 & 0.38 & 9.550 & 400 & 6 & 1.11 & 33.2 \\
\hline & 21.0 & 20.5 & 1.5 & -.. & $\ldots$ & $\cdots$ & 1,550 & 400 & 7 & 1.76 & 34.6 \\
\hline & 28.0 & 26.5 & 1.25 & $\cdots$ & 2,250 & 0.33 & 18,000 & 400 & 6. & .1 .38 & 42.5 \\
\hline & 27.0 & 25.5 & 1.21 & 26,600 & 10,000 & 0.47 & 15,120 & 400 & 7 & 1.42 & 40.3 \\
\hline & 25.0 & 23.5 & 1.05 & 24,200 & 5.800 & 0.43 & 13,420 & 400 & 7 & 1.23 & 34.2 \\
\hline & 25.5 & 24.0 & 0.92 . & 4,000 & 6.250 & 0.38 & 24,300 & 400 & 7 & 1.08 & 32.4 \\
\hline & 34.0 & 22.5 & 0.85 & 90,000 & 129,000 & 0.46 & $\begin{array}{l}\text { Static } \\
\text { failure }\end{array}$ & & 7 & 1.00 & 92.4 \\
\hline $30 \% \mathrm{CW}$ & 58.0 & 22.0 & $\mathbf{0}: 68 / \mathbf{0 . 4 3}$ & $\cdots$ & -.- & $\cdots$ & $\begin{array}{l}\text { Static } \\
\text { Failure }\end{array}$ & 400 & 7 & $0.80 / 0.50$ & $72.6 / 57.1$ \\
\hline \multirow{2}{*}{$\begin{array}{l}30 \% \mathrm{CH} \\
\text { +Irradiated }\end{array}$} & 31.0 & 30.0 & $1 / 2$ & $\cdots$ & 1,350 &.-- & 1,428 & 400 & 7 & 0.59 & 29.0 \\
\hline & 19.0 & 18.0 & $1-1 / 2$ & $\cdots$ & 1,543 & $\cdots$ & 2,468 & 400 & 7 & 1.76 & 31.9 \\
\hline \multirow{4}{*}{$\begin{array}{l}\text { Heat Yreated } \\
+15 \% \mathrm{CH} \\
+159 \mathrm{and} \\
+ \text { Hydrided }\end{array}$} & 15.0 & 15.0 & 0.25 & \multicolumn{4}{|c|}{$\begin{array}{l}\text { (Failed in first few } \\
\text { cycles). }\end{array}$} & 3,000 & 7 & 0.29 & 9.5 \\
\hline & 14.0 & 12.5 & 0.46 & $<13,000$ & 23,800 & $\cdots$ & 25,830 & 3,000 & 7 & 0.54 & 12.0 \\
\hline & 12.5 & 11.0 & 1.61 & 2635,000 & $\ldots$ & $\cdots$ & 685,040 & 3,000 & 10 & 1.49 & 21.0 \\
\hline & 11.5 & 11.0 & 1.68 & 250,000 & $\begin{array}{c}120,000 \\
\text { (Estiniated) }\end{array}$ & $\cdots$ & 176,000 & 10,000 & 10 & 1.55 & 19.9 \\
\hline \multirow{3}{*}{$\begin{array}{l}\text { Heat Treated } \\
\text { + Aged ted } \\
+ \text { Hydrided }\end{array}$} & 17.4 & 16.0 & 1.2 & 215,000 & $\mathbf{s 0 , 1 8 0}$ & $\cdots$ & 79,120 & 400 & 7 & 1.41 & 25.4 \\
\hline & 20.0 & 19.5 & 0.76 & 210,000 & $i 8,500$ & $\cdots$ & 49,680 & 400 & 7 & 0.89 & 22.7 \\
\hline & 26.0 & 23.5 & 0.42 & 23,700 & 6,470 & $\ldots$ & 6,522 & 400 & 7 & 0.49 & 21.9 \\
\hline $\begin{array}{l}30 \% \mathrm{CH} \text { and } \\
\text { Hydrided }\end{array}$ & 17.0 & 14.5 & 3.05 & 40,000 & 53,850 & $\cdots$ & --- & 400 & 7 & 3.57 & 48.3 \\
\hline $\begin{array}{l}30 \% \mathrm{CW} \text { and } \\
\text { Hydrided }\end{array}$ & 21.0 & 17.5 & 2.6 & $\sim 10,000$ & 17,900 & $\cdots$ & 47,000 & 400 & 7 & 3.04 & 52.4 \\
\hline $\begin{array}{l}60 \% \mathrm{CW} \text { and } \\
\text { Hydrided }\end{array}$ & 21.0 & 20.0 & $\cdots$ & 215,000 & 23,300 & $\cdots$ & & 400 & 7 & --. & $\cdots$ \\
\hline \multirow{2}{*}{$\begin{array}{l}30 \% \mathrm{CH} \\
+ \text { Hydrided and } \\
\text { Irrradiated }\end{array}$} & 15.0 & 14.5 & $0.5^{*}$ & 384 & $\cdots$ & $\cdots$ & 10,101 & 400 & 7 & 0.59 & 13.5 \\
\hline & 12.0 & 11.5 & $1.5^{*}$ & $\cdots$ & $\cdots$ & $\cdots$ & 5 & 400 & 7 & 1.76 & 19.9 \\
\hline \multirow{2}{*}{$\begin{array}{l}\text { Heat Treated } \\
+15 \% \mathrm{cW} \\
+ \text { Hydrided }\end{array}$} & 25 & 24 & 0.83 & $\cdots$ & $\ldots$ & $\cdots$ & $\cdots$ & 3,000 & 20 & 0.93 & 30.0 \\
\hline & 30 & 285 & 0.38 & --. & $\cdots$ &.-- & -.. & 3,000 & 20 & 0.42 & 24.2 \\
\hline
\end{tabular}


Table 22. MILLED SLOT FRACTURE DATA FOR IRRADIATED AND UNIRRADIATED Zr-Nb PRESSURE TUBES (From Reference 5, 57)

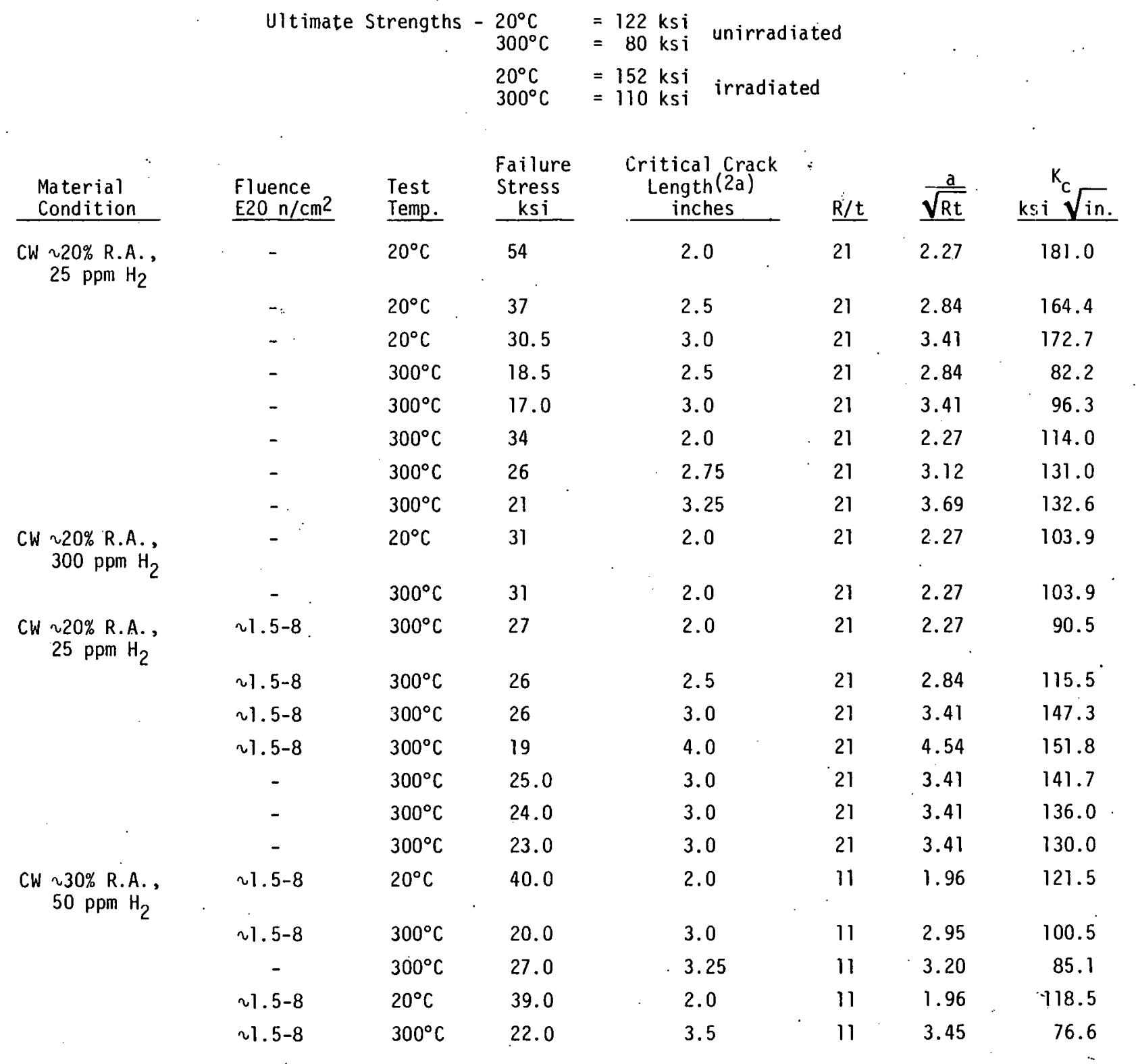


Table 23. POSTIRRADIATION BURST TESTS OF ZIRCALOY-2 PRTR PRESSURE TUBES

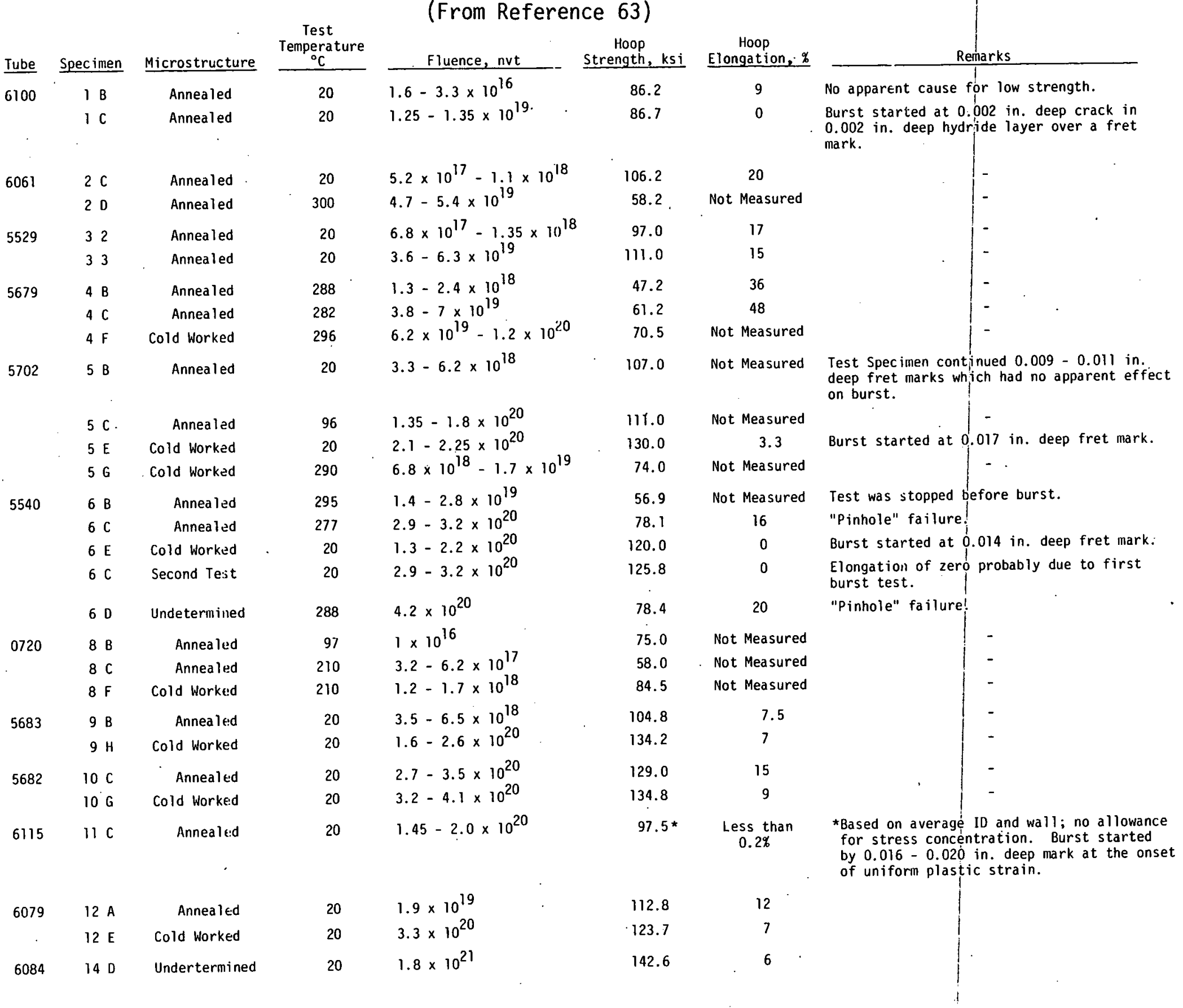


Table 24. IRRADIATION GROWTH MEASUREMENTS ON ZIRCALOY-2

(From Reference 64)

\section{Growth Coefficient}

\begin{tabular}{|c|c|c|c|c|c|c|c|c|}
\hline \multirow{2}{*}{$\begin{array}{c}\begin{array}{c}\text { Irradiation } \\
\text { Temper- } \\
\text { ature }\end{array} \\
-195^{\circ} \mathrm{C}\end{array}$} & \multirow{2}{*}{$\begin{array}{c}\begin{array}{c}\text { Fluence } \\
\mathrm{n} / \mathrm{cm}^{2}\end{array} \\
4.9 \times 10^{18}\end{array}$} & $\begin{array}{c}\text { Measured } \\
\text { Differential } \\
\text { Growth Strain }\end{array}$ & \multicolumn{2}{|c|}{$\begin{array}{l}\text { Instan- } \\
\text { taneous } \\
\mathrm{G}_{\mathrm{t}_{2}}{ }^{-} \mathrm{t}_{1}\end{array}$} & \multicolumn{2}{|c|}{$\begin{array}{l}\text { Average } \\
\mathrm{G}_{\mathrm{t}_{2}}{ }^{-} \mathrm{t}_{1}\end{array}$} & $\begin{array}{c}\text { Number } \\
\text { of } \\
\text { Speci- } \\
\text { mens } \\
\end{array}$ & \multirow{2}{*}{$\begin{array}{l}\text { Reactor } \\
\text { Herald }\end{array}$} \\
\hline & & $1.2 \pm 0.2 \times 10^{-4}$ & 8.0 & \pm 1.0 & 18.0 & \pm 4.0 & 3 & \\
\hline \multirow{7}{*}{$40^{\circ} \mathrm{C}$} & 9.7 & 0.3 & 5.0 & 1.0 & 11.6 & 2.3 & 4 & \\
\hline & $1.9 \times 10^{19}$ & 0.3 & 3.5 & 0.5 & 9.5 & 1.1 & 3 & \\
\hline & 5.0 & 0.5 & 2.0 & 0.3 & 5.2 & 0.7 & 3 & \\
\hline & 9.8 & 0.1 & 1.5 & 0.2 & 2.3 & 0.1 & 4 & \\
\hline & $8.2 \times 10^{18}$ & 0.2 & 8.0 & 1.0 & 19.0 & 1.0 & 7 & \\
\hline & $2.9 \times 10^{19}$ & 0.2 & 3.6 & 0.3 & 10.2 & 0.4 & 7 & \\
\hline & $1.0 \times 10^{20}$ & 0.4 & 1.7 & 0.2 & 4.0 & 0.3 & 7 & \\
\hline \multirow[t]{3}{*}{$80^{\circ} \mathrm{C}$} & $1.3 \times 10^{20}$ & 0.4 & 0.6 & 0.1 & 1.7 & 0.2 & 4 & Pluto \\
\hline & 5.4 & 0.4 & 0.30 & 0.03 & 0.7 & 0.1 & 7 & \\
\hline & 7.7 & 1.0 & 0.20 & 0.02 & 0.6 & 0.1 & 4 & \\
\hline \multirow[t]{4}{*}{$280^{\circ} \mathrm{C}$} & $2.2 \times 10^{17}$ & \multicolumn{3}{|c|}{9} & & & 1 & Herald \\
\hline & $1.0 \times 10^{18}$ & \multicolumn{3}{|c|}{5} & & & 1 & \\
\hline & $1.0 \times 10^{19}$ & \multicolumn{3}{|c|}{3} & & & 1 & \\
\hline & 3.0 & \multicolumn{3}{|c|}{1.5} & & & 1 & \\
\hline
\end{tabular}

